\title{
Experimental autoimmune myasthenia gravis : target organ resistance and immunogenetics
}

Citation for published version (APA):

Graus, I. M. F. (1992). Experimental autoimmune myasthenia gravis : target organ resistance and immunogenetics. [Doctoral Thesis, Maastricht University]. Datawyse / Universitaire Pers Maastricht. https://doi.org/10.26481/dis.19921218ig

Document status and date:

Published: 01/01/1992

DOI:

10.26481/dis.19921218ig

Document Version:

Publisher's PDF, also known as Version of record

\section{Please check the document version of this publication:}

- A submitted manuscript is the version of the article upon submission and before peer-review. There can be important differences between the submitted version and the official published version of record.

People interested in the research are advised to contact the author for the final version of the publication, or visit the DOI to the publisher's website.

- The final author version and the galley proof are versions of the publication after peer review.

- The final published version features the final layout of the paper including the volume, issue and page numbers.

Link to publication

\footnotetext{
General rights rights.

- You may freely distribute the URL identifying the publication in the public portal. please follow below link for the End User Agreement:

www.umlib.nl/taverne-license

Take down policy

If you believe that this document breaches copyright please contact us at:

repository@maastrichtuniversity.nl

providing details and we will investigate your claim.
}

Copyright and moral rights for the publications made accessible in the public portal are retained by the authors and/or other copyright owners and it is a condition of accessing publications that users recognise and abide by the legal requirements associated with these

- Users may download and print one copy of any publication from the public portal for the purpose of private study or research.

- You may not further distribute the material or use it for any profit-making activity or commercial gain

If the publication is distributed under the terms of Article $25 \mathrm{fa}$ of the Dutch Copyright Act, indicated by the "Taverne" license above, 
Experimental autoimmune myasthenia gravis: Target organ resistance and immunogenetics 
Production and layout: DATAWYSE I Universitaire Pers Maastricht

CIP-DATA KONINKLIJKE BIBLIOTHEEK, DEN HAAG

Graus, Ivo Maria Franciscus

Experimental autoimmune myasthenia gravis : target organ

resistance and immunogenetics / Ivo Maria Franciscus

Graus. - Maastricht : Universitaire Pers Maastricht. |ll

Proefschrift Maastricht. - Met lit. opg

ISBN 90-5278-051-X

NUGI 743

Trefw: Myasthenia gravis / autoimmuunziekten

Het in dit proefschrift gepresenteerde onderzoek werd mogelijk gemaakt door subsidie van het Beatrix Fonds. In de drukkosten van het proefsehrift werd bijgedragen door de firma Bio Rad. 


\section{Experimental autoimmune myasthenia gravis: Target organ resistance and immunogenetics}

\section{PROEFSCHRIFT}

ter verkrijging van de graad van doctor

aan de Rijksuniversiteit Limburg te Maastricht. op gezag van de Rector Magnificus, Prof. Mr. M.J. Cohen, volgens het besluit van het College van Dekanen,

in het openbaar te verdedigen

op vrijdag, 18 december 1992 om 16.00 uur

door

Ivo Maria Franciscus Graus

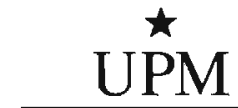

UNIVERSITAIRE PERS MAASTRICHT 
Promotor:

Prof.dr. P.J.C, van Breda Vriesman

Co-promotor:

Dr. M.H. De Baets

Beoordelingscommissie:

Prof,dr. J.W. Arends (voorzitter)

Prof.dr. J.P.M. Geraedts

Dr. T. Logtenberg (Rijksuniversiteit Utrecht)

Prof.dr. H.J.G.H. Oosterhuis (Rijksuniversiteit Groningen)

Prof.dr. F. Spaans 
"A thousand miles journey begins with a single step." Lao Tzu, 600 B.C.

Opgedragen aan mijn ouders Voor Lucie 


\section{Contents}

Abbreviations 6

Introduction 7

Chapter 1:

Myasthenia gravis: an autoimmune response against the acetylcholine receptor 12

Chapter 2:

Age related resistance to experimental autoimmune myasthenia gravis in rats 42

Chapter 3:

The genetic basis of antibody diversity 62

Chapter 4:

Characterization of anti-acetylcholine receptor antibodies from mice differing in susceptibility for experimental autoimmune myasthenia gravis 78

Chapter 5:

$V_{H}$ gene family utilization of anti-acetylcholine receptor antibodies in murine experimental autoimmune myasthenia gravis 100

Chapter 6:

$V_{H}$ gene family utilization of rat anti-acetylcholine receptor monoclonal antibodies 118

Summary and general discussion 131

Samenvatting en algemene discussie 137

Publications 147

Dankwoord 149

Curriculum vitae 151 


\section{ABBREVIATIONS}

$\alpha$-BT : $\alpha$-bungarotoxin

AChR : Acetylcholine receptor

Anti-ld : Anti-idiotype

CFA : Complete Freund's adjuvant

CMAP : Compound muscle action potential

CRI : Cross-reactive idiotype

EAMG : Experimental autoimmune myasthenia gravis

ELISA : Enzyme linked immune sorbent assay

HRP : Horse radish peroxidase

Id : Idiotype

mAb : Monoclonal antibody

MIA : Main immunogenic region

MG : Myasthenia gravis

PBS : Phosphate buffered saline

RIA : Radio immune assay

SPRIA : Solid phase radio immune assay

$V_{H} \quad$ : Heavy chain variable region

$V_{L} \quad$ : Light chain variable region 


\section{Introduction}

Myasthenia gravis (MG) is an organ-specific autoimmune disease that results from an antibody mediated assault on the muscle nicotinic acetylcholine receptor at the neuromuscular junction (1). Binding of antibodies to the acetylcholine receptor leads to loss of functional acetylcholine receptors, and impairs the neuromuscular signal transmission, resulting in muscular weakness. Although myasthenia gravis is a rare disease with an annual incidence of about 4 per million, it is one of the best studied autoimmune diseases. The disease is examplary for autoantibody mediated target tissue injury.

Our understanding of the pathogenesis of $M G$ is considerably enhanced because of the molecular characterization of the acetylcholine receptor and the presence of a well characterized animal model: experimental autoimmune myasthenia gravis (EAMG) $(2,3)$. This experimental model is induced by immunization of rodents with purified acetylcholine receptor (AChR) or passive transfer of anti-acetylcholine receptor antibodies into these animals. The EAMG model resembles human MG in many respects (1). Although a great deal of information exists about the immunopathological mechanisms involved in acetylcholine receptor destruction, it is not known what aetiological factors determine the susceptibility for the disease.

The aim of this study was to investigate the factors responsible for the development of the disease in the EAMG model. In this model, the immunesystem can be triggered to produce an autoantibody response against the acetylcholine receptor. One line of approach was to investigate the properties of the anti-AChR antibody repertoire in relation to disease susceptibility. A second line of approach was to induce the effector phase of EAMG and study the immunological and physiological events at the neuromuscular junction; this junction is the target of the autoimmune response against the AChR.

Therefore, two main topics can be discerned in this thesis. First, susceptibility for induction of EAMG by a monoclonal anti-AChR antibody was found to be influenced by age. Age related resistance to EAMG provided a model in which immunological and physiological factors involved in the effector phase of the disease were studied in relation to disease susceptibility.

In the second part of this thesis the interest was focussed on characterization of the anti-AChR antibody repertoire elicited by immunization with AChR.

On the one hand the fine specificity of anti-AChR antibodies was studied in relation to disease susceptibility and on the other hand the diversity of anti-AChR antibodies was investigated by determining the genetic elements that code for these antibodies. The concept that autoantibodies are encoded by a limited number of genetic elements (4-6) was investigated for anti-AChR antibodies. 
Chapter 1 is an introduction to the disease myasthenia gravis, its animal model and the target antigen(s) to which the autoimmune response is directed.

Chapter 2 describes the age related resistance to the induction of EAMG in rats. Aged rats, in contrast to young adult rats, were found to be resistant to the induction of EAMG by passive transfer of a monoclonal anti-AChR antibody. The mechanism(s) that underlie the resistance to disease are evaluated.

Chapter 3 introduces the second part of this thesis and reviews antibody structure and the genetic basis of antibody diversity.

Chapter 4 describes the isolation and characterization of anti-AChR receptor monoclonal antibodies from two mouse strains that differ in their susceptibility for the chronic form of EAMG. In addition, the fine specificities of circulating anti-AChR antibodies from high and low susceptible mice were determined at several time points after induction of chronic EAMG.

Chapter 5 describes the diversity in genes encoding the heavy chain variable region of anti-AChR antibodies isolated from high and low susceptible mice.

Chapter 6 characterizes the heavy chain variable region gene families in the rat and the genetic diversity of well defined rat anti-AChR monoclonal antibodies against defined antigenic regions on the acetylcholine receptor. 


\section{REFERENCES}

1 Lindstrom J, Shelton D, Fujii Y. (1988). Myasthenia gravis. Adv. Immunol. 42:233-284

2 Lennon VA, Lindstrom JM, Seybold ME. (1975). Experimental autoimmune myasthenia gravis: a model of myasthenia gravis in rats and guinea pigs. J. Exp. Med. 141: 1365-1375

3 Lindstrom JM, Einarson BL, Lennon VA, Seybold ME. (1976). Pathological mechanisms in experimental autoimmune myasthenia gravis. I. Immunogenicity of syngeneic muscle acetylcholine receptor and quantative extraction of receptor and antibody-receptor complexes from muscles of rats with experimental autoimmune myasthenia gravis. J. Exp. Med. 144:726-728

4 Monestier M, Manheimer-Lory A, Bellon B, Painter C, Dang H, Talal N, Zannetti M, Schwartz R, Pisetsky D, Kuppers R, Rose N, Brochier J, Klaresog L, Holmdahl R, Erlanger B, Alt F, Bona C. (1986). Shared idiotopes and restricted immunoglobulin variable region heavy chain genes characterize murine autoantibodies of various specificties $\mathrm{J}$. Clin. Invest. 78:753-759

5 Trepicchio W, Barrett K. (1987). Eleven MRL-Ipr/lpr anti-DNA autoantibodies are encoded by genes from four $V_{H}$ gene families: A potentially biased usage of $V_{H}$ genes. $J$. immunol. 138:2323-2331

6 Bellon B, Manheimer-Lory A, Monestier M, Dimitriu-Bona A, Alt F, and Bona C. (1987). High frequency of autoantibodies bearing cross-reactive idiotopes among hybridomas using $V_{H} 7183$ genes prepared from normal and autoimmune murine strains. J. Clin. Invest. 79:1044-1053 


\section{Chapter 1}

Myasthenia gravis:

an autoimmune response against

the acetylcholine receptor 


\section{Myasthenia gravis: an autoimmune response against the acetylcholine receptor}

\section{THE ACETYLCHOLINE RECEPTOR}

\section{Introduction}

In 1936 Dale et al demonstrated that stimulated nerve-muscle preparations produced acetylcholine, and that this substance caused contractions in muscle preparations (1). The notion of a specific acetylcholine receptor protein was next postulated by Nachmansohn in 1952 (2). Discovery of $\alpha$-neurotoxins, in particular $\alpha$-bungarotoxin from the venom of Bungarus multicintus made it possible to define the nature of the receptor (3). Isolation of the receptor from the electric organs of Torpedo californica was first achieved in the early seventies by several investigators using $\alpha$-toxins (4-7). Patrick and Lindstrom further characterized the AChR which led to the observation that myasthenia gravis was caused by an autoimmune response against the acetylcholine receptor (8). In the next decade monoclonal antibodies were used to define important pathogenic epitopes, and the use of molecular biology has revealed much information about the structure and function of the AChR.

\section{Structure and function}

The transmission of impulses from nerve to muscle depends on release of acetylcholine from the motor nerve ending and subsequent interaction with the acetylcholine receptor (AChR). Binding of acetylcholine to the AChR opens the AChR ion channel, allowing $\mathrm{Na}^{+}$ions to enter and to depolarize the muscle membrane, leading to contraction of the muscle. AChRs are located in the postsynaptic membrane at the neuromuscular junction. The postsynaptic membrane has deep infoldings that increase the surface area up to 10 times the lengths of the presynaptic membrane $(9,10)$. The AChR is situated at the top of these folds at a high density of 8-10 thousend molecules per $\mu \mathrm{m}^{2}(11,12)$.

The amount of AChR in mammalian skeletal musle is about $10 \mu \mathrm{g} / \mathrm{kg}$. The electric organs of Torpedo californica and other electric rays and eels however, provide a richer source of AChR. The electroplax tissue contains approximately $100 \mathrm{mg} / \mathrm{kg}$ $A C h R$ and therefore was the starting point for purification and characterization of 
the receptor. Since the AChR is an evolutionairy well conserved molecule, much information obtained from these fish AChRs can be applied to mammalian skeletal muscle $\operatorname{AChR}(13,14)$. Information about the structural and functional properties of the AChR has been obtained from sequence analysis of the genes that code for the AChR subunits. At present the AChR genes have been sequenced from Torpedo, calf, rat, mouse, chicken (15) and human (16-19). The homology between Torpedo and mammalian AChR (calf) is about $80 \%$ for the $\alpha$-subunit and $55 \%$ for the other subunits (20-23).

The AChR of electric fish is a transmembrane protein composed of four different subunits in a stochiometry $\alpha \beta \alpha \gamma \delta$ (24-26). The apparent and calculated protein molecular weights of these subunits from Torpedo AChR are $\alpha: 38000$ and 50116 , $\beta: 49000$ and $53681, \gamma: 57000$ and $56279 \delta: 64000$ and 57565 dalton (13). The AChR molecule is approximately $125 \AA$ long of which the extracellular domain protrudes $55 \AA$ above the membrane and the intracellular domain extends $15 \AA$ below the membrane (14). From above AChRs are seen as $85 \AA$ diameter ring-like structures protruding from the membrane $(15,16)$. The independent subunits have considerable aminoacid sequence homology as a consequence of their evolution from a common ancestor gene by gene duplication (13). Therefore, the structure and transmembrane orientation is similar between the different subunits. The extracellular domain is formed by the $\mathrm{N}$-terminal 210 aminoacids which are predominantly hydrophylic and contain the acetylcholine binding site near the double cysteine residues at position $192-193(29,30)$. The transmembrane part of the subunits is formed by four hydrophobic transmembrane helices called $M 1$ to $M 4(13,31-34)$. The cytoplasmic domain of each subunit is formed by a loop between the third and fourth transmembrane domains and contain an amphipathic helix (MA) composed of hydrophobic and hydrophylic residues. The transmembrane domains M1, M2, and M3 from each subunit participate in formation of the ion channel, in which the M2 domain of each subunit lines the pore (35-37).

The sequence homology between equivalent subunits from mammalian species is around $97 \%$ for the $\alpha$-subunit and $90 \%$ for the other subunits with the highest homology found in the transmembrane domains M1, M2 and M3 (38).

The AChRs present in foetal (non-innervated) and denervated muscle are found at a low density of $500 / \mu \mathrm{m}^{2}$ over most of the sarcolemmal surface $(39,40)$. Several differences between embryonic (non-junctional) and mature junctional AChR are observed. Non-junctional AChRs have a half-life of about 1 day versus 10 days for junctional AChR and have a lower conductance but a 4 times longer open time compared to junctional $\mathrm{AChR}(41)$, and show differences in immunological properties (42-45). The distinctive properties between these AChR types result from the presence of a $\gamma$ subunit in embryonic AChR which is replaced by the $\varepsilon$ subunit in junctional AChR (46-48). This subunit replacement takes place during the first postnatal week in rats (49) and around 33 weeks in utero in the human fetus (50). The acetylcholine binding site is localized at the outer surface of the $\alpha$-subunits (26), and 2 acetylcholine molecules must bind simultaneously to the 2 binding sites on each AChR to open the cation channel. The effect of acetylcholine is terminated through hydrolysis by acetylcholine esterase anchored in the basal lamina between nerve and muscle. Opening of the cation channel is effectuated in less than $100 \mu \mathrm{s}$ 
and persists for $\approx 1-2 \mathrm{~ms}$ in adult type $A C h R$, followed by a non-conductance state of $\approx 50 \mathrm{~ms}$ during which the $A C h R$ is non-sensitive to the following activation by acetylcholine (51-54).

\section{Antigenic structure of $A C h R$ in $M G$ and $E A M G$}

In myasthenia gravis the acetylcholine receptor is target of an autoimmune response. The symptoms of the disease are mediated entirely by anti-AChR antibodies since the disease can be passively transferred with IgG (55). Formation of autoantibodies requires $A C h R$ specific $B$ lymphocytes as well as AChR specific $T$ helper lymphocytes that stimulate the B cells to make anti-AChR antibodies (56-59). AChR specific $B$ cells recognize mainly conformation dependent determinants of the native $A C h R$, whereas $T$ cells recognize 13-17 amino acid peptides processed and presented by the antigen presenting cell in association with the MHC class II antigen (60). Much effort has been expended on elucidating the antigenic determinants (epitopes) recognized by pathogenic anti-AChR antibodies as well as epitopes activating AChR specific $T$ cells, which may provide clues about the pathogenesis and applications of immune intervention.

\section{B cell epitopes}

In order to characterize the B cell epitopes on the AChR, monoclonal antibodies were isolated from mice, rats and humans against the AChR from Torpedo, (61-68), electric eel (69), fetal calf (66), chicken (70) and human (43, 71-73). Several antigenic regions have been characterized on both extra- and intracellular parts of the AChR. A characteristic feature of the AChR is the presence of a main immunogenic region (MIR) to which many anti-AChR mAbs are directed $(63,69,72)$. Anti-MIR mAbs can inhibit the binding of $50 \%$ or more of the antibodies to AChR from the serum of $M G$ patients $(74,75)$, or rats immunized with $A C h R(76)$. Antibodies directed to the MIR do not directly impair AChR function (77) but can cross-link adjacent AChR molecules causing AChR loss by increasing the rate of AChR internalization (78). Binding of antibodies to the MIR is highly dependent on the intact conformation of the $\operatorname{AChR}(76,79-81)$. The MIR region is localized on the $\alpha$-subunit and has been mapped to residues $67-76$ by binding to synthetic peptides (82-84). The immunodominant epitope(s) are mainly formed by the residues 68-71 for which a hairpin like loop with a type I $\beta$-turn is predicted (85). Anti-MIR mAbs interact with different amino acids within the sequence 67-76 (85-87), but residues 68 and 71 are indispensable for binding of all anti-MIR mAbs (87-89).

Other antigenic regions on the AChR include the residues $\alpha 128-142(90)$ which forms a loop at the extraceliular part of the $\alpha$-subunit and elicit pathogenic antiAChR antibodies (91). Antibodies to this region are found in most MG patients and around $50 \%$ of total anti-AChR antibodies was found to be directed to this region (92).

Furthermore, antibodies against the acetylcholine/ $\alpha$-bungarotoxin binding site can be demonstrated in most MG patients, by inhibition of $\alpha$-bungarotoxin binding to 
the AChR (93). The binding of $\alpha$-bungarotoxin and several cholinergic agonists has been confined to the synthetic peptides $\alpha 160-216$ (82), $\alpha 173-204$ (94), $\alpha 181-200$ (95), $\alpha 185-196$ (96), and $\alpha 189-195$ (97) of Torpedo AChR or $\alpha 181-200$ (98), 185-199 (99) of the human AChR.

In general antibody epitopes are dependent on the conformation and particular charge patterns of the native AChR molecule rather than linear sequences (100).

\section{T cell epitopes}

Antibodies mainly bind to conformation dependent determinants, whereas $T$ cells frequently recognize epitopes on the linear sequence of a protein. T cell stimulatory epitopes are therefore not necessarilly the same as for antibody production (101). T cells can be activated by native AChR, denatured AChR or its subunits $(57,102$, 103). Synthetic peptides corresponding to the primary sequence of AChR have been used to stimulate lymphocytes and select $T$ cell lines or clones specific for immunodominant T cell epitopes on the AChR. Several peptide sequences have been identified that stimulate $T$ lymphocytes from inbred mice and rats. The peptides $\alpha 97-112$ (104), $\alpha 73-90$ and $\alpha 100-116$ (103) of Torpedo AChR strongly stimulate $T$ lymphocytes from Lewis rats whereas $T$ lympocytes from C57bl/6 mice are stimulated by the sequences $\alpha 195-212$ and $\alpha 259-271$ from human AChR (105) and $\alpha 146-162$ from Torpedo $\operatorname{AChR}(106,273)$. It was demonstrated that the $T$ cell response of different animal strains was peptide specific and $\mathrm{MHC}$ class II restricted (103, 105). Furthermore, immunodominant $T$ cell epitopes may not necessarily be similar in Torpedo and human (mammalian) AChR (104).

Several sequence regions of the human AChR $\alpha$-subunit stimulating T lymphocytes from MG patients, have now been identified. Many of these T-cell stimulating epitopes are located within the extracellular part of the $\alpha$-subunit and include: $\alpha 1-14, \alpha 6-22, \alpha 18-34$ (107), $\alpha 48-62, \alpha 101-120(108,109), \alpha 85-142(110), \alpha 146-162$ (111) $\alpha 169-181$ (112), $\alpha 162-216$ (113) and $\alpha 37-181$ (114). Immunodominant $T$ cell epitopes were also demonstrated between the transmembrane regions $\mathrm{M} 2$ and $\mathrm{M} 3$ (115), within the cytoplasmic domain $(108,109,112)$, or at the C-terminus of the $\alpha$-subunit $(108,109)$. T cell stimulatory epitopes on subunits other than the $\alpha$-subunit were demonstrated on the $\delta 121-290$ sequence (116) and on the $\gamma$ subunit which is only present in embryonic muscle (117). In summary, these results indicate that individual MG patient's T lymphocytes may recognize more than one antigenic determinant on the AChR subunits and that the $T$ lymphocyte response vary considerable among individual patients with different HLA phenotypes $(111,113)$. Interindividual variablility of the T cell specificities can be partially explained by the fact that $T$ helper cells recognize the AChR peptides in association with differing $\mathrm{MHC}$ class II molecules; the antigenic determinant binding to the MHC class II molecule (agretope) restricts the possible stimulatory epitopes for the Thelper cells (118).

$T$ cell epitopes are mostly different from B cell epitopes $(81,103,119)$. Immunodominant $\mathrm{T}$ cell epitopes are predominantly derived from the $\alpha$-subunit and are found on both extracellular and cytoplasmic domains of the AChR. 


\section{MYASTHENIA GRAVIS}

The first description of the symptoms of myasthenia gravis goes back to the year 1672 in which Thomas Willis described a patient with a curious fluctuating weakness which he called 'paralysia spuria non habitualis'. Since then, additional cases were described by Hérard, Charcot, Erb, and Goldflam in the period 1868 to 1893. Jolly et al first described electromyographic abnormalities in MG patients and introduced the name myasthenia gravis pseudoparalytica. Since 1893, many hypotheses addressing the pathophysiology have been proposed including involvement of toxic or curariform substances, influencing the motor neurons or endplate, and abnormalities of the thymus (120). An important contribution to the understanding and treatment of myasthenia came from Mary Walker who noticed that the symptoms of MG resembled curare poisoning. Hence, she treated MG patients with physostigmine, an agonist for curare intoxication which resulted in a considerable improvement of the disease (121). From this time it was assumed that the distrurbance causing the symptoms was localized at the neuromuscular transmission.

The autoimmune nature of MG was first proposed in 1960 by Simpson. He suggested that in myasthenia gravis antibody to endplate protein may be formed, which would have the properties of an acetylcholine-competitive-blocking substance (122). In the same year Nastuk observed that MG sera were cytotoxic to muscle membranes (123). Ultrastructural evidence for a postsynaptic defect in MG was provided by Engel and Santa (124). The first experimental indication for the autoimmune nature of MG was provided by Patrick and Lindstrom who induced MG like symptoms in rabbits by immunizing with purified AChR (8). In the same year Fambrough et al showed a reduction in the number of junctional AChRs in biopsies of MG patients (125). Subsequently, antibodies against the acetylcholine receptor were detected in the sera of MG patients $(93,126)$. Since then, much information about the immunological and pathophysiological mechanisms has been compiled. Several acquired and congenital myasthenic syndromes can be distinguished. Acquired MG is a postsynaptic disorder of neuromuscular transmission in which at least three disease entities can be distighuised: I, Idiopathic autoimmune MG. II. Transient MG induced by the drug D-penicillamine (127), and III. Transient neonatal MG induced by maternal anti-AChR antibodies (128). Another acquired myasthenic disorder is the Lambert-Eaton myasthenic syndrome in which autoantibodies against the presynaptic voltage gated calcium channels impair neuromuscular transmission (129).

Congenital MG has a non-immunological aetiology and includes several pre- and postsynaptic defects regarding acetylcholine (re)synthesis, packaging and mobilization, acetylcholine esterase deficiency, AChR deficiency or regulation of AChR density, AChR ligand affinity, and abnormal gating properties of the $\operatorname{AChR}(130$, 131, 133).

Acquired myasthenia gravis is an autoimmune disease affecting neuromuscular transmission. Autoantibodies directed against the acetylcholine receptor at the postsynaptic membrane result in fluctuating weakness of voluntary muscle and excessive fatigue. The disease usually has a variable course depending in part on the magnitude of the autoimmune response, but also on fluctuations in AChR reserve and the synaptic quantal content. The symptoms may be confined to ocular 
or bulbar muscles or may be generalized also involving limb and trunk muscles, in part depending on the exertion of the muscles concerned. The impaired neuromuscular transmission is electromyographically characterized by decrement of action potentials upon repetitive stimulation and an increased jitter, which is an increased variability in neuromuscular transmission in separate endplates (134). Symptoms of MG are temporarily relieved by acetylcholine esterase inhibitors or rest (121). A more persistant remission of severe cases can be obtained by thymectomy, plasmaphoresis, and immunosuppresion (120). Antibodies against human AChR are found in $85-90 \%$ of MG patients with generalized symptoms and in $70 \%$ of patients with ocular symptoms $(126,135)$. The majority of MG sera lacking IgG anti-AChR antibodies in conventional radio immuno assays contain IgM antibodies that impair AChR function in vitro (136).

MG has a prevalence of about one out of 20000 , and is most frequently observed in women of the child bearing age or men over 40 years (120). Patients with MG have been divided into three groups based on thymic pathology, age of onset and associations with different HLA polymorphisms (137).

\begin{tabular}{llll}
\hline & subgroup I & subgroup II & subgroup III \\
thymic pathology & hyperplasia & thymoma & thymic atrophy \\
age of onset & $<40$ & $30-60$ & $>40$ \\
HLA association & B8, DR3 & - & $B 7$, DR2 \\
sex predominance (M:F) & $1: 3$ & $1: 1$ & $2: 1$ \\
\hline
\end{tabular}

Although not absolute, the association with these haplotypes suggests a strong role for immunogenetic factors in disease susceptibility. Analysis of a HLA-DR3 subregion revealed that $M G$ patients expressing this region have a relative risk of 35 compared to controls (138). Furthermore, a region between HLA B8 and the TNF locus within the $\mathrm{MHC}$ region, was found to be present in all group I patients possibly containing genes that determine MG susceptibility (139) However, the obvious differences in thymic pathology and HLA associations suggests that other aetiological factors or predisposing factors must contribute to the triggering of the autoimmune response in MG (140).

\section{Possible aetiologic factors in $M G$}

Although MG is one of the best characterized autoimmune diseases it is not yet determined what initiates and sustains the autoimmune response to AChR. Environmental factors like viral infection have been proposed to trigger loss of tolerance to $A C h R(141)$. However, no virus could be isolated from MG thymuses $(142,143)$ and the incidence of serum antibodies against several viruses was not significantly different from matched controls (144). Molecular mimicry between bacterial or viral determinants and epitopes on the AChR was also proposed as an initial trigger (145-150). Sharing of epitopes was demonstrated between the human sequence 
$\alpha .160-167$ and the herpes simplex virus glycoprotein $(146,148,149)$, and partial sequence similarity was found between the MIR $\alpha 67-76$ and the polymerase polyprotein sequence of several human retroviruses (150). In addition, the MIR sequence is highly homologous to the U1 small nuclear ribonucleoprotein, which is a marker autoantigen for SLE and mixed connective tissue disease (150).

Another postulated mechanism triggering an autoimmune response is binding of a neoantigen to the acetylcholine receptor (151). The drug D-peniciliamine induces a transient form of MG in which anti-AChR antibodies and AChR loss is observed (127). The disease is reversed in about 8 months after D-penicillamine is omitted (152). The antigenicity of the AChR may be altered by binding of penicillamine, resulting in a transient loss of tolerance (151). In both D-penicillamine MG and neonatal MG anti-AChR antibodies are present which induce but do not sustain the disease. The fact that remission from the antibody mediated attack of the neuromuscular junction occurs in these forms of MG indicates that the mere presence of antibody is not sufficient to account for development of MG; additional factors must be present to break tolerance completely, thus perpetuating the disease for many years. A clue may be found in the fact that $M G$ is sometimes observed after bone marrow transplantation in humans $(153,154)$. A possible defect in T cell education (selection) in the thymus may underlie this phenomenon and may eventually lead to loss of tolerance to the highly immunogenic AChR. Interesting evidence for this hypothesis is provided by an animal model for cyclosporin induced graft versus host disease (155) in which rats are lethally irradiated, reconstituted with syngeneic bone marrow and treated with cyclosporin for 4 weeks. After withdrawal of cyclosporin treatment, animals develop several autoimmune phenomena including occasionally myasthenia gravis (156). The thymus may be 'leaky' during this treatment, and autoreactive clones probably escape from selection or suppression in the thymus (155)

\section{The role of the thymus in MG}

Thymic abnormalities are frequently found in myasthenia gravis patients $(157,158)$, suggesting an important aetiological role for the thymus. Thymic hyperplasia is frequently found among patients under 40 years of age and thymectomy often leads to improvement of MG (159). The hyperplastic thymus is characterized by germinal centers and large $T$ cell areas. Both anti-AChR antibody producing B cells (160) and AChR specific T cells (59) are present in hyperplastic thymuses. Myoid cells expressing embryonic type $A C h R$ are demonstrated in normal or MG thymic medulla $(161,162)$. Interaction of myoid cells with interdigitating cells may initiate an autoimmune response (163).

Thymomas are found in approximately $15 \%$ of MG patients and are usually associated with a later age of onset of the disease (120). The AChR is not present in thymoma tissue $(162,164,165)$. However, mRINA coding for the $\alpha$-subunit could be amplified from thymoma epithelial cells using the polymerase chain reaction (166). Other proteins ( $45 \mathrm{kd}$ and $153 \mathrm{kd}$ ) biochemically different from AChR but sharing an intracellular epitope with the $A C h R$, were demonstrated on thymoma epithelium of MG patients (167). Thymomas associated with MG are selectively 
enriched in AChR reactive T cells (168). However, synthesis of anti-AChR antibody does not occur in the thymoma tissue itself, but in adjacent hyperplastic tissue (169). The anti-AChR antibody production in the MG thymus correlates well with serum titer. The in vitro production of anti-AChR antibodies by periferal blood lymphocytes was shown to disappear after thymectomy (170). However, the serum anti-AChR titer falls to a varying extent after thymectomy $(171,172)$. Moreover, AChR responsive $T$ lymphocytes can still be detected (173). These findings indicate that the thymus is not the only site of anti-AChR antibody production $(171,172)$; the majority of the antibody is probably produced in the bone marrow (174).

\section{EXPERIMENTAL AUTOIMMUNE MYASTHENIA GRAVIS}

An experimental model for myasthenia gravis was discovered fortuitously in 1973 by Patrick and Lindstrom characterizing the acetylcholine receptor from electric eel. Rabbits immunized with purified AChR developed muscular weakness characteristic for $\mathrm{MG}$. As in MG, the clinical signs diminished after treatment with acetylcholine esterase inhibitor (8). Experimental Autoimmune Myasthenia Gravis (EAMG) can be induced in mice, rats, guinea pigs and monkeys (175-177) by immunization with AChR from the electric organs of Electrophorus electricus or Torpedo californica.

EAMG provides an excellent model for MG and is very similar to MG with respect to electrophysiological, biochemical and immunological parameters (178). The two major differences between MG and EAMG are the absence of thymic abnormalities (179) and the self-limiting nature of the autoimmune response in EAMG. Although EAMG provides only little information about the events initiating $M G$, it shows that the autoimmune response in $\mathrm{MG}$ is similar to that obtained upon immunization with native AChR.

\section{Induction of acute and chronic EAMG}

EAMG can be induced in laboratory animals by immunization with purified syngeneic AChR (180) fetal calf AChR (181) and AChR from the electric organs of Electrophorus electricus or Torpedo californica (180) incorporated in complete Freund's adjuvant (CFA). EAMG is commonly induced by immunization with Torpedo AChR. Although there is a $80 \%$ sequence homology between Torpedo and mammalian AChR $\alpha$-subunit (20), only about $2 \%$ of anti-Torpedo AChR antibodies cross-react with syngeneic AChR (182). However, native Torpedo AChR is highly immunogenic inducing autoantibody concentration typical for MG patients after immunization with $1 \mu \mathrm{g}$ or more Torpedo AChR. The first clinical signs of EAMG are seen 4 to 6 weeks after immunization when autoantibody titers peak (183). Affected animals show a generalized weakness, are unable to support their weight, have a hunched back, abducted thighs and flexed digits. In the chronic stage animals have difficulties in swallowing and show excessive growth of the teeth due to impairment of the masticatory muscles. Animals die from respiratory insufficiency, malnutrition and dehydration (176, 184). 
When rats are immunized with Torpedo AChR in CFA with additional Bordetella pertussis vaccin, a biphasic course of the disease is observed (176). The acute form is seen $8-10$ days after immunization and is transient. During the acute phase muscle endplates are invaded by phagocytic cells intruding into the muscular junction probably leading to focal denervation (184, 185). Animals recover from acute EAMG upon disappearance of phagocytic cells from endplates and stay in remission until 4-6 weeks after immunization when the first signs of chronic EAMG arise. When additional Bordetella pertussis vaccin is omitted, only the chronic phase of EAMG is observed (178).

The great immunogenic potential of AChR was demonstrated in mice by repeated intraperitoneal immunization of membrane bound (186) or purified syngeneic AChR (187) from the mouse tumor cel line $\mathrm{BC} 3 \mathrm{H}-1$ without adjuvant. Immmunization of mice with Torpedo AChR without adjuvants is also possible though less effective (188).

EAMG can also be induced by the individual AChR subunits (189) or synthetic peptides corresponding to defined regions of the AChR. Repeated immunization with a synthetic peptide corresponding to residues 125-147 of the $\alpha$-subunit from Torpedo $(91)$ or human AChR $(190,191)$ induced T cell responses and antibodies to native $A C h R$, capable of modulating $A C h R$ in vitro. Peptide immunized rats showed reduced miniature endplate potentials and loss of AChR characteristic for EAMG. Another peptide, corresponding to $\alpha$-subunit residues $183-200$ containing the cholinergic binding site, induced EAMG by immunopharmacological blockade of the acetylcholine binding site (192). Both modulating and blocking antibodies were found after immunization of rats with recombinant human $\alpha 1-210$ fusion protein produced in E. coli, which comprises the whole extracellular part of the $\alpha$-subunit (193). Other groups however, did not find electrophysiological or biochemical evidence for EAMG in mice, rats and rabbits immunized with synthetic peptides or recombinant human $\alpha$-subunit (194-197). This may be explained by the absence of the proper three-dimensional structure in short synthetic peptides, since antibody epitopes are highly conformation dependent and anti-peptide antibodies do not necessarily bind to the native AChR. Furthermore, peptides and bacterial fusion proteins are not glycosylated which may influence antibody binding.

\section{Passive transfer EAMG}

EAMG can be induced by passive transfer of polyclonal $(198,61)$ or monoclonal (199-201) anti-AChR antibodies indicating that the disease is entirely mediated by antibody. Similar clinical signs as in chronic EAMG are seen in passive transfer EAMG 12 to $48 \mathrm{hrs}$ after injection of anti-AChR antibody (202). Animals usually die within 72 hours or recover after clearance of the antibody. Recovered rats were found to be resistant to another passive transfer up to 11 weeks after the initial injection (203). Passive transfer EAMG resembles the acute form of EAMG in that infiltrating mononuclear cells are observed around the end plate region (204).

A chronic form of EAMG can be induced in rats by repeated administration of anti-AChR monoclonal antibody for 9-12 weeks, resulting in AChR loss, ultrastruc- 
tural simplification of endplates and decreased miniature endplate potentials, but no clinical weakness (205).

\section{Disease susceptibility}

Susceptibility to induction of EAMG and severity of disease symptoms may vary considerably among different species and between different strains of a species. Considerable diffences are found among inbred rat strains: Wistar Munich and Fischer rats consistently develop EAMG, Lewis and BN rats show intermediate susceptibility and Wistar Furth and Copenhagen rats are resistant to EAMG (206). Cross-breeding of different strains showed that disease susceptibilty is recessive and is linked to one or two genetic loci.

Mice are less susceptible for induction of EAMG than rats and development of muscular weakness is only seen after a second immunization with Torpedo AChR (207). The susceptibility to EAMG differs in genetically defined strains of mice (208, 175) and is determined by several loci including the major histocompatibility complex, immunoglobulin and complement alleles $(209,210)$. The $1-A_{\beta}$ chain of the mouse $\mathrm{MHC}$ class II molecule was shown to play an important role in the T-cell response to Torpedo AChR (211). In addition, a mutation at the I-A $\beta$ chain in C57bl/6bm 12 mice prevents in part EAMG in vivo (212). Several other physiological factors, which together determine the "safety factor" of neuromuscular transmission (130), influence the susceptibility for EAMG.

\section{Pathology of acetylcholine receptor destruction}

Clinical manifestations and disease severity of EAMG in animals can be diagnosed by several means including endurance tests to measure muscular weakness ( 175 , 176), loss of body weight caused by the inability to eat or drink (179), or electromyographic evaluation of the neuromuscular transmission. An impaired neuromuscular signal transmission can be demonstrated by measuring the decline in the amplitude of the compound muscle action potential upon repetitive nerve stimulation (decrement) (213), or by stimulated single fiber electromyography measuring the variability of the time interval between stimulus artefact and the action potential of a single muscle fiber (jitter) $(214,215)$.

Induction of EAMG is accompanied by several pathological changes at the neuromuscular junction. Different pathology can be observed during the bi-phasic course of EAMG. During the acute phase of EAMG, between day 7 and 11, an inflammatory exsudate composed of mononuclear phagocytic cells and some neutrophils is seen around the endplate. Occasional muscle fibers show segmental necrosis and invasion of macrophages immediately adjacent to the endplate region. Ultrastructural evaluation of the neuromuscular junction reveal degeneration of the terminal expansions of the postsynaptic membrane and a widened synaptic space filled with debris. The nerve terminal remains intact but is separated from the muscle fibers by infiltrating macrophages which may cause local denervation. The length of the highly simplified postsynaptic membrane is decreased $(184,185)$. These pathologi- 
cal changes observed during the acute phase of EAMG are also seen 24-72 hours after passive transfer of anti-AChR antibodies $(179,216)$. Remission from acute phase EAMG coincides with disappearance of the phagocytic cells and the reestablishment of close contact between nerve terminals and the regenerating postsynaptic region. After 3-4 weeks some animals relapse into the chronic phase of EAMG in which the degeneration of the postsynaptic membrane becomes more intense. A renewed invasion of macrophages is not seen $(184,185)$. This chronic stage in EAMG is characterized by loss of $50-70 \%$ of the muscle AChR (180), and the morphological changes at the neuromuscular junction resemble those found in human MG $(184,185,124)$. However, no equivalent for an acute phase in human MG has been demonstrated so far (128).

\section{Pathogenic mechanisms}

Several lines of evidence have clearly demonstrated that $M G$ is an antibody mediated autoimmune disease. Passive transfer of IgG from MG patients to mice induces the clinical signs of MG including decrement and AChR loss $(198,217)$. Furthermore, transient neonatal MG can be observed in babies from myasthenic mothers and is dependent on circulating anti-AChR antibodies in the baby (218, 219). Removal of anti-AChR antibodies from the patient by plasmaphoresis (or immuneadsorbens) has been proven to be beneficial in the treatment of $M G$ (220-222).

The degradation or inactivation of functional AChR by anti-AChR antibodies observed in $\mathrm{MG}$ is probably caused by several mechanisms. The major part of the anti-AChR antibodies do not directly inhibit AChR function but lead to loss of AChR.

\section{Antigenic modulation:}

First, anti-AChR antibodies may result in AChR loss by cross-linking of adjacent receptor molecules thereby accelerating the $A C h R$ turnover rate $(223,224)$. Under normal conditions AChR is turned over by endocytosis and intracellular proteolytic degradation within lysosomes. Cross-linking of AChR molecules is called antigenic modulation, and increases the degradation of AChR on cultured muscle cells in vitro by a factor 2 to 6 (223-228). Antigenic modulation is temperature and energy dependent but independent of complement $(225,229)$. Antigenic modulation by purified IgG from EAMG rats could be demonstrated in vitro using the mouse muscle cell line $\mathrm{BC} 3 \mathrm{H}-1$ or diaphragms removed from rats $(230,231)$. Antigenic modulation is dependent on divalent antibodies since monovalent antigen binding fragments (Fab) were ineffective $(224,230)$. Antibodies directed to the MIR or other extracelIular epitopes are especially effective in modulating the AChR (232). In fact 68-80 $\%$ of the modulating capacity of MG sera can be blocked by the Fab fragment of an anti-MIR mAb $(233,234)$

Several studies have investigated the modulating potential of MG sera using rat muscle culture $(223,224,235-238)$, mouse $\mathrm{BC} 3 \mathrm{H}-1$ cells $(228,229,239,240)$, human myotubes (233) or the AChR expressing human medulloblastoma cell line TE671 (234). Modulating antibodies were found in 66-100\% of MG patients sera $(233,235,237,238)$. The modulating potential of MG sera was mainly dependent 
on the anti-AChR antibody titer (233). A correlation between observed AChR degradation by $M G$ sera and the severity of $M G$ is a topic of debate. A correlation between the degrading potential and the clinical state of the patient was found by some investigators $(235,237,238)$ but contradicted by others $(233,236)$. It was however clearly demonstrated in all studies that antibodies from patients with mild or severe MG symptoms may have the same modulating capacity, suggesting that additional factors determine the patient's susceptibility to the disease.

\section{Complement mediated lysis:}

Another major mechanism of AChR degradation is the complement mediated focal lysis of the postsynaptic membrane. Binding of antibody to the AChR can activate the classical complement pathway generating the anaphylotoxins $\mathrm{C} 3 \mathrm{a}$ and $\mathrm{C5a}$ which trigger an inflammatory reaction and formation of the lytic membrane attack complex (MAC) by components C5b-C9 that form a pore in the cell membrane leading to focal lysis of the muscle membrane (241). Complement component C3 and the MAC have been demonstrated at the neuromuscular junction of MG patients $(242,243)$ and a linear correlation was found between the length of the postsynaptic membrane bound with $\mathrm{C} 3$ and the decrease in miniature endplate potential (242). Moreover, MG sera induce complement dependent myotoxicity in vitro in rat myotubes $(244,245)$. C3 containing immune complexes at the neuromuscular junction were also demonstrated in chronic (246) and passive transfer EAMG (216). In both MG and chronic EAMG complement contributes to AChR degradation by focal lysis of the postsynaptic membrane. In addition, the early corriplement components $\mathrm{C} 3 \mathrm{a}$ and $\mathrm{C} 5 \mathrm{a}$ together with $\mathrm{C} 3 \mathrm{~b}$ and $\mathrm{C} 3 \mathrm{bi}$ may attract and bind phagjocytic: cells to the damaged endplate in acute or passive transfer EAMG. The important contribution of complement mediated degradation to the pathogenesis of the disease was demonstrated in complement deficient or complement depleted animals. C4 deficient guinea pigs or C5 deficient mice immunized with AChR had significant less AChR loss and failed to develop clinical signs of chronic EAMG (210, 247). Similar, acute or passive transfer EAMG by mono- and polyclonal anti-AChR antibodies failed to develop in C4 deficient guinea pigs (248), or C3 depleted rats or mice $(249,55)$. Induction of passive transfer EAMG could also be prevented by pretreatment of rats with anti-complement C6 Fab antibody which inhibits the formation of the MAC (250). Anti-C6 treatment completely inhibited the accumulation of macrophages indicating that AChR degradation is dependent on focal lysis of the postsynaptic membrane and antigenic modulation of AChRs rather than the action of macrophages (250).

\section{Functional inactivation of $A C h R$ :}

The binding of anti-AChR antibodies may also result in functional inactivation of the AChR by interfering with either acetylcholine binding or impairment of the ion channel function. Isolation of monoclonal antibodies from AChR immunized animals demonstrates the existance of antibodies blocking the cholinergic binding sites (62, $64,65,68,251$ ) or inhibiting ion channel function (252). MG sera were demonstrated to reduce the MEPP under non-degrading conditions, indicating the presence of antibodies that directly block AChR function (253-255). Blocking antibodies have been demonstrated in MG sera by inhibition of $\alpha$-bungarotoxin binding to AChR in 
muscle culture or TE671 cells $(93,237,256-263)$. The number of MG patients having blocking antibodies varied from $48-98 \%$, depending on the assay system used $(237,259-261)$. The relevance of blocking antibodies in vivo was shown by the protective effect of some MG sera against the lethal toxicity of $\alpha$-bungarotoxin in mice (262). The amount of blocking antibody in MG patients may vary from 0-33\% of total anti-AChR antibodies (258). The blocking capacity of MG sera was often not related to the severity of the disease in generalized $M G$. Blocking antibodies are absent from sera of asymptomatic or ocular MG patients $(260,261)$.

Antibodies interfering with the ion channel function of AChR were demonstrated among $M G$ and EAMG anti-AChR antibodies which reduced the agonist-induced $\mathrm{Na}^{+}$influx through the AChR in TE671 cells $(264,265,136)$. The action of blocking antibodies may be important especially when the AChR number is reduced.

\section{The cellular immune response to $\mathrm{AChR}$}

Several experiments in the EAMG model demonstrated T cell mediated immunity against AChR. A short and transient delayed type hypersensitivity reaction to AChR was observed 3 days after immunization (56). EAMG can be transferred to naive recipients by lymphnode cells (56). However, passive transfer of antibody alone is sufficient to induce all the features of MG. In addition, lymphocytes from EAMG animals have no direct cytotoxic effect on muscle cells in vitro (266). Therefore, antibodies against the AChR clearly mediate the effector phase of myasthenia gravis. However, the production of anti-AChR antibodies is T cell dependent. This was demonstrated in vivo in rats depleted by $X$-irradiation and thymectomy and subsequently reconstituted with $B$ cells alone, which were unable to mount an immune response against the AChR, thus preventing the induction of EAMG (56). Similarly, anti-AChR antibody production by lymphnode cells from EAMG rats in vitro was completely prevented when T cells were selectively depleted (57). The AChR specific $T$ cells express the helper phenotype and proliferation is $\mathrm{MHC}$ class II restricted (268).

Infiltration of macrophages was observed during the acute phase of EAMG or after passive transfer of anti-AChR antibody $(184,185,204)$. In contrast, these cells are not observed in chronic EAMG (246). An equivalent of this acute phase has never been demonstrated in human $M G$, and may not be detected during early development of the disease (178). The role of inflammation in human myasthenia gravis is still controversial. Inflammatory infiltrates are only rarely seen in intercostal and limb muscle biopsies $(124,9,269,270)$, whereas others demonstrated mononuclear cells at the endplate regions in triceps- (271) or anconeus muscle (272). Whether these cells actively contribute to the disease process, or function as phagocytic cells that sequester the remnants of the destructed postsynaptic membrane, remains to be determined. 


\section{REFERENCES}

1 Dale H, Feldberg W, Vogt M. (1936). Release of acetylcholine at voluntary motor nerve endings. J. Physiol. 86:353-380

2 Nachmansohn D. (1952). In: Modern Trends In Physiology and Biochemistry. Barrón ESG, Ed. Academic Press, New York. p 230

3 Lee CY. (1972). Chemistry and pharmacology of polypeptide toxins in snake venoms. Annu. Rev. Pharmacol. 12:265-280

4 Meunier J-C, Huchet M, Boquet P, Changeux J-P. (1971). Separation de la protéine réceptrice de l'acétylcholine et de acétylcholine esterase. C R Acad Sci, ser. D272:117 Klett RP, Fulpius BW, Cooper D, Smith M, Reich E, Possani LD. (1973). The acetylcholine receptor: I. Purification and characterization of a macromolecule isolated from Electrophorus electricus. J. Biol. Chem. 248:6841-6853

Biesecker G. (1973). Molecular properties of the cholinergic receptor purified from Electrophorus electricus. Biochemistry 12:4403 4409

7 Karlin A, Cowburn. (1973). The affinity-labeling of partially purified acetylcholine receptor from electric tissue of Electrophorus. Proc. Natl. Acad. Sci. USA 70:3636-3640

8 Patrick J, Lindstrom JM. (1973). Autoimmune response to acetylcholine receptor. Science 180:871-872

9 Santa T, Engel AG, Lambert EH. (1972). Histometric study of neuromuscular junction ultrastructure. 1. Myasthenia gravis. Neurology 22:71-82

10 Santa T, Engel AG, Lambert EH. (1972). Histometric study of neuromuscular junction ultrastructure. II. Myasthenic syndrome. Neurology 22:370-376

11 Salpeter MM. (1987). Development and neural control of the neuromuscular junction and of the junctional acetylcholine receptor. In: The vertebrate neuromuscular junction, Salpeter MM, ed. Alan Liss, New York, pp 55-115

12 Bevan S, Steinbach $\mathrm{JH}$. (1977). The distribution of $\alpha$-bungarotoxin binding sites on mammalian skeletal muscle developing in vitro. J. Physiol. 254:345-364

13 Noda $M$, Takahashi $H$, Tanabe $T$, Toyosato $M$, Kikyotani $S$, Furutani $Y$, Hirose $T$, Takashima H, Inayama S, Miyata T, Numa S. (1983). Structural homology of Torpedo californica acetylcholine receptor subunits. Nature 302:528-532

14 Popot J-L, Changeux J-P. (1984). Nicotinic receptor of acetylcholine: structure of an oligomeric integral membrane protein. Physiol. Rev. 64:1162-1239

15 Claudio T. (1989). Molecular genetics of acetylcholine receptor channels. In: Frontiers in Molecular Biology, Molecular Neurobiology, Glover D, and Hames D, Eds. IRL Press, Oxford pp 63-126

16 Beeson D, Brydson M, Wood H, Vincent A, Newsom-Davis J. (1989). Human muscle AChR: Cloning and expression in E. coli of CDNA for the $\alpha$-subunit. Biochem. Soc. Trans. 17:219-220

17 Beeson D, Brydson M, Newsom-Davis J. (1989). Nucleotide sequence of human muscle AChR beta subunit. Nucleic Acids Res. 17:4391

18 Schoepfer R, Luther M, Lindstrom J. (1988). The human medulloblastoma cell line TE 671 expresses a muscle like acetylcholine receptor. FEBS Lett. 226:235-240

19 Luther M, Schoepfer R, Whiting P, Casey B, Blatt Y, Montal M, Lindstrom J. (1989). A muscle AChR is expressed in the human cerebrellar medulloblastoma cell line TE 671. J. Neurosci. 9: 1082-1096

20 Noda M, Furutani Y, Takahashi H, Toyosato M, Tanabe T, Shimizu S, Kikyotani S, Kayano T, Hirose T, Inayama S, Numa S. (1983). Cloning and sequence analysis of calf cDNA encoding $\alpha$-subunit precursor of muscle acetylcholine receptor. Nature 305:818-823

21 Tanabe T, Noda M, Furutani $Y$, Takai T, Takahashi H, Tanaka K, Hirose T, Inayama S, Numa S. (1984). Primary structure of $\beta$ subunit precursor of calf muscle acetylcholine receptor deduced from cDNA sequence. Eur. J. Biochem. 144:11-17 
22 Takai T, Noda M, Furutani Y, Takahashi H, Notake M, Shimizu S, Kayano T, Tanabe T, Tanaka K, Hirose T, Inayama S, Numa S. (1984). Primary structure of $y$ subunit precursor of calf-muscle acetylcholine receptor deduced from the cDNA sequence. Eur. J. Biochem. 143:109-115

23 Kubo T, Noda M, Takai T, Tanabe T, Kayano T, Shimizu S, Tanaka K, Takahashi H, Hirose T, Inayama S, Kikuno R, Miyata T, Numa S. (1984). Primary structure of $\delta$ subunit precursor of calf muscle acetylcholine receptor deduced from cDNA sequence. Eur. J. Biochem. 149:5-13

24 Lindstrom J. Merlie J, Yogeeswaran G. (1979). Biochemical properties of acetylcholine receptor subunits from Torpedo californica. Biochem. 18:4465-4470

25 Raftery MA, Hunskappiler MW, Stradler CD, Hood LE. (1980). Acetylcholine receptor: . complex of homologous subunits. Science 208:1454-1457

26 Kubalek E, Ralston S, Lindstrom J, Unwin N. (1987). Localization of subunits within the acetylcholine receptor by electron image analysis of tubular crystals from Torpedo marmorata. J. Cell Biol. 105:9-18

27 Kistler (1982). Structure and function of an acetylcholine receptor. J. Biophys. 37:371-383

28 Toyoshima C, Unwin N. (1990). Three-dimensional structure of the acetylcholine receptor by cryoelectron microscopy and helical image reconstruction. J. Cell. Biol. 111:26232635

29 Kao P, Dwork A, Kaldany R, Silver M, Wideman J, Stein S, Karlin A. (1984). Identification of the subunit half cysteine specifically labeled by an affinity reagent for the acetylcholine receptor binding site. J. Biol. Chem. 259:11662-11665

30 Kao P, Karlin A. (1986). Acetylcholine receptor binding site contains a disulphide cross-link between adjacent half-cysteinyl residues. J. Biol. Chem. 261:8085-8088

31 Devillers-Theiry A, Giraudat J, Bentaboulet M, Changeux J-P. (1983). Complete mRNA coding sequence of the acetylcholine binding subunit of Torpedo marmorata acetylcholine receptor: a model for the transmembrane organization of the polypeptide chain. Proc. Natl. Acad. Sci. USA 80:2067-2071

32 Claudio T, Ballivet M, Patrick J, Heinemann S. (1983). Torpedo californica acetylcholine receptor 60,000 dalton subunit: nucleotide sequence of cloned cDNA deduced amino acid sequence, subunit structural predictions. Proc. Natl. Acad. Sci. USA 80: 111-115

33 Guy R. (1983). A structural model of the acetylcholine receptor channel based on partion energy and helix packing calculations. J. Biophys. 45:249-261

34 Chavez RA, Hall ZW. (1992). Expression of fusion proteins of the nicotinic acetylcholine receptor from mammalian muscle identifies the membrane-spanning regions in the $\alpha$ and $\delta$ subunits. J. Cell. Biol. 116:385-393

35 Imoto K, Methfessel C, Sakmann B, Miscina M, Mori Y, Konno T, Fukada K, Kurasaki M, Bujo H, Fujita Y, Numa S. (1986). Localization of a delta subunit region determining ion transport through the membrane. Nature 324:670-674

36 Imoto K, Bush C, Sakmann B, Mishina M, Konno T, Nakai J, Bujo H, Mori Y, Fukada F, Numa S. (1988). Rings of negatively charged aminoacids determine the acetylcholine receptor channel conductance. Nature 335:645-648

37 Leonard R, Labarca C, Charnet P, Davidson N, Lestr H. (1988). Evidence that the M2 membrane-spanning region lines the ion-channel pore of the nicotinic receptor. Science 242:1578-1581

38 Beeson D, Barnard E. (1990). Acetylcholine receptors at the neuromuscular junction. In: Neuromuscular Transmission. basic and applied aspects. Vincent A, and Wray D, Eds. Manchester University Press, pp 157-181

39 Diamond J, Miledi R. (1962). A study of the foetal and newborn rat muscle fibers. J. Physiol. 162:393-408

40 Bevan S, Steinbach JH. (1977). The distribution of $\alpha$-bungarotoxin binding sites on mammalian skeletal muscle developing in vitro. J. Physiol. 267:195-213 
41 Salpeter MM. (1987). Development and neural control of the neuromuscular junction and of junctional acetylcholine receptor. In: The vertebrate neuromuscular junction, Salpeter MM. Ed. Alan Liss, New York, pp 55-115

42 Hall ZW, Gorin PD, Siberstein L, Bennet C. (1985). A postnatal change in the immunological properties of the acetylcholine receptor at rat muscle endplate. J. Neurosci. 5:730734

43 Whiting PJ, Vincent A, Schluep M, Newsom-Davis J. (1986). Monoclonal antibodies that distinghuish between normal and denervated human acetylcholine receptor. J. Neuroimmunol. 11:223-235

44 Gu Y, and Hall ZW. (1988). Immunological evidence for a change in subunits of the acetylcholine receptor in developing and denervated rat muscle. Neuron 1:117-125

45 Nelson S, Shelton GD, Lei S, Lindstrom J, Conti-Tronconi BM. (1992). Epitope mapping of monoclonal antibodies to Torpedo acetylcholine receptor $\gamma$ subunits, which specifically recognize the $\varepsilon$ subunit of mammalian muscle acetylcholine receptor. J. Neuroimmunol. 36:13-27

46 Takai T, Noda M, Mishina M, Shimizu S, Furutani Y, Kayano T, Ikeda T, Kubo T, Takahashi $H$, Takahashi T, Kuno M, Numa S. (1985). Cloning sequencing and expression of CDNA for a novel subunit of AChR from calf muscle. Nature 315:761-764

47 Mishina M, Takai T, Imoto K, Noda M, Takahashi T, Numa S, Methfessel C, Sakman B. (1986). Molecular distinction between fetal and adult forms of muscle acetylcholine receptor. Nature 321:406-411

48 Witzemann V, Stein E, Barg B, Konno T, Koenen M, Kues W, Criado M, Hoffmann M, Sakmann B. (1990). Primary structure and functional expression of the $\alpha-, \beta-, \gamma-, \delta$-, and $\varepsilon$-subunits of the acetylcholine receptor from rat muscle. Eur. J. Bicchem. 194:437-448

49 Witzemann V, Barg B, Reese TS. (1989). Differential regulation of muscle acetylcholine receptor $\alpha$ - and $\varepsilon$ subunit mRNAs. FEBS Lett. 223:104-112

50 Slater C, Vincent A. (1990). Structure and development of the neuromuscular junction. In: Neuromuscular transmission. Basic and applied aspects. Vincent A, and Wray D, Eds. Manchester University Press, pp 1-26

51 Adams PR. (1981). acetylcholine receptor kinetics. J. Membr. Biol 58:161-174

52 Dionne VE, Leibowitz. (1982) Acetylcholine receptor kinetics. A description from singlechannel currents at snake neuromuscular juntions. d. Biophys. 39:253-261

53 Dreyer F. (1982). Acetylcholine receptor. Br. J. Anaesth. 54:115-130

54 Peper K, Bradley RJ, Dreyer F. (1982). The acetylcholine receptor at the neuromuscular junction. Physiol. Rev. 62:1271-1340

55 Toyka KV, Drachman DB, Griffin DE, Pestronk A, Winkelstein JA, Fishbeck KH, Kao I. (1977). Myasthenia gravis. Study of humoral immune mechanisms by passive transfer to mice. N. Eng. J. Med. 296:125-131

56 Lennon VA, Lindstrom JM, Seybold ME. (1976) Experimental autoimmune myasthenia gravis: cellular and humoral immune responses. Ann. N.Y. Acad. Sci. 274:283-299

57 De Baets MH, Einarson B, Lindstrom JM, Weigle WO. (1982). Lymphocyte activation in experimental autoimmune myasthenia gravis. J. Immunol. 128:2228-2235

58 Krolick KA, Urso OE. (1987) Analysis of helper-T-cell function by acetylcholine receptorreactive cell lines of defined AChR-subunit specificity. Cell. Immunol. 105:75-85

59 Melms A, Schalke BCG, Kirchner T, Müller-Hermelink, Albert E, Wekerle H. (1988) Thymus in myasthenia gravis: isolation of T-lymphocyte lines specific for the nicotinic acetylcholine receptor from the thymuses of myasthenia gravis patients. J. Clin. Invest. 81:902-908

60 Rudensky AY, Preston-Hurlburt P, Hong SC, Barlow A, Janeway CA. (1991). Sequence analysis of peptides bound to MHC class II molecules. Nature 353:622-627

61 Lennon VA Lambert EH. (1980). Myasthenia gravis induced by monclonal antibodies to acetylcholine receptors. Nature 285:238-240 
62 Gomez CM, Richman DP, Berman PW, Burres SA, Arnason BGW, Fitch FW. (1979). Monoclonal antibodies against purified nicotinic acetylcholine receptors. Biochem. Biopys. Res. Commun. 88:575-582

63 Tzartos SJ, Lindstrom JM. (1980). Monoclonal antibodies used to probe acetylcholine receptor structure. Localization of the main immunogenic region and detection of similarities between subunits. Proc. Natl. Acad. Sci. USA. 77:755-759

64 Watters D, Maelicke A. (1983). Organization of ligand binding sites at the acetylcholine receptor: A study with monoclonal antibodies. Biochemistry 22:1811-1819

65 Whiting P, Vincent A, Newsom-Davis J. (1985). Monoclonal antibodies to Torpedo acetylcholine receptor. Characterisation of antigenic determinants within the cholinergic binding site. Eur. J. Biochem. 150:533-539

66 Tzartos S, Langeberg L, Hochschwender S, Swanson LW, Lindstrom J. (1986). Characteristics of monoclonal antibodies to denatured Torpedo and native calf acetylcholine receptors: Species, subunit and region specificity. J. Neuroimmunol. 10:235-253

67 Chase BA, Holiday J, Reese JH, Chun LLY, Hawrot E. (1987). Monoclonal antibodies with defined specificities for Torpedo nicotinic acetylcholine receptor cross-react with Drosophila neural tissue. Neuroscience 21:959-976

68 Dowding AJ, Hall ZW. (1987). Monoclonal antibodies specific for each of the two toxin-binding sites of Torpedo acetylcholine receptor. Biochemistry 26:6372-6381

69 Tzartos SJ, Rand DE, Einarson BL, Lindstrom JM. (1981). Mapping of surface structures of electrophorus acetylcholine receptor using monoclonal antibodies. J. Biol. Chem. 256:8635-8645

70 Mehraban F, Kemshead JT, Dolly JO. (1984). Properties of monocional antibodies to nicotinic acetylcholine receptor from chick muscle. Eur. J. Biochem. 138:53-61

71 Vernet der Garabedian B, Morel E. (1983). Monoclonal antibodies against the human acetylcholine receptor. Biochern. Biophys. Res. Commun. 113:1-9

72 Tzartos S, Langeberg L, Hochschwender S, Lindstrom J. (1983). Demonstration of a main immunogenic region on acetylcholine receptors from human muscle using monoclonal antibodies to human receptor. FEBS Lett. 158:116-118

73 Blair DA, Richman DP, Taves CJ, Koethe S. (1986). Monoclonal antibodies to acetylcholine receptor secreted by human $x$ human hybridomas derived from lymphocytes of a patient with myasthenia gravis. Immunol. invest. 15:351-364

74 Tzartos S, Seybold M, Lindstrom J. (1982). Specificity of antibodies to acetylcholine receptors in sera from myasthenia gravis patients measured by monoclonal antibodies. Proc. Natl. Acad. Sci. USA 79:188-192

75 Whiting PJ, Vincent A, Newsom-Davis J. (1986). Monoclonal anti-human acetylcholine receptor antibodies used to analyze antibody specificities and responses to treatment. Neurology 36:612-617

76 Froehner SC. (1981). Identification of exposed and buried determinants of the membrane bound acetylcholine receptor from Torpedo californica. Biochemistry 20:4905-4915

77 Blatt Y, Montal M, Lindstrom J, Montal M. (1986). Monoclonal antibodies directed against epitopes in the $\beta$ and $\gamma$ subunits of Torpedo cholinergic receptor affect channel gating. J. Neurosci. 6:481-486

78 Conti-Tronconi B, Tzartos S, Lindstrom J. (1981). Monoclonal antibodies as probes of acetylcholine receptor structure. II. Binding to native receptor. Biochemistry 20:21812191

79 De Baets MH. (1984). Autoimmunity to cell surface receptors. Thesis, B.V. Leiter-Nypels, Maastricht, The Netherlands. pp 94-95

80 Ratnam M, Sargent PB, Sarin V, Fox JL, Nguyen DL, Rivier J, Criado M, Lindstrom J. (1986). Localization of the antigenic determinants on primary sequences of subunits of nicotinic acetylcholine receptor by peptide mapping. Biochemistry. 25:2621-2632 
81 Ratnam M, Nguyen DL, Rivier J, Sargent PB, Lindstrom J. (1986). Transmembiane topography of nicotinic acetylcholine receptor: Immunochemical tests contradict theoretical predictions based on hydrophobicity profiles. Biochemistry. 25:2633-2643

82 Barkas T, Mauron A, Roth B, Alliod C, Tzartos S, Ballivet M. (1987). Mapping of the main immunogenic region and toxin binding site of the nicotinic acetylcholine receptor. Science 235:77-80

83 Barkas T, Gabriel J-M, Mauron A, Hughes G, Roth B, Alliod C, Tzartos S, Ballivet M. (1988). Monoclonal antibodies to the main immunogenic region of the nicotinic acetylcholine receptor binds to residues 61-76 of the $\alpha$-subunit. J. Biol. Chem. 263:9516-5920

84 Tzartos S, Kokla A, Walgrave S, Conti-Tronconi B. (1988). Localization of the main immunogenic region of the human acetylcholine receptor to residues $67-76$ of the $\alpha$-subunit. Proc. Natl. Acad. Sci. USA 85:2899-2903

85 Tzartos SJ, Loutrari HV, Tang F, Kokla A, Walgrave SL, Milius RP, Conti-Tronconi B. (1990). Main immunogenic region of Torpedo electroplax and human acetylcholine receptor: localization and microheterogeneity revealed by the use of synthetic peptides. J. Neurochem. 54:51-61

86 Bellone M, Tang F, Milius R, Conti-Tronconi B. (1990). The main immunogenic region of the acetylcholine receptor. Identification of amino acid residues interacting with different antibodies. J. Immunol. 143:3568-3579

87 Papadouli I, Potamianos S, Hadjidakis I, Bairaktaki E, Tsikaris V, Sakarellos C, Cung MT, Marraud M, Tzartos SJ. (1990). Antigenic role of single residues within the main immunogenic region of the nicotinic acetylcholine receptor. J. Biochem. 269:239-245

88 Das MK, Lindstrom J. (1989). The main immunogenic region of the nicotinic acetylcholine receptor: interaction of monoclonal antibodies with synthetic peptides. Biochem. Biophys. Res. Commun. 165:865-871

89 Saedi MS, Anand R, Conroy WG, Lindstrom J. (1990). Determination of amino acids critical to the main immunogenic region of intact acetylcholine receptors by in vitro mutagenesis. FEBS Lett. 267:55-59

90 Wood H, Beeson D, Vincent A, Newsom-Davis. (1989). Epitopes on human acetylcholine receptor $\alpha$-subunit: binding of monoclonal antibodies to recombinant and synthetic peptides. Biochem. Soc. Trans. 17:220-221

91 Lennon VA, McCormick DJ, Lambert EH, Griemann GE, Zouhair Atassi M. (1985). Region of peptide 125-147 of acetylcholine receptor $\alpha$ subunit is exposed at neuromuscular junction and induces experimental autoimmune myasthenia gravis, T-cell immunity, and modulating autoantibodies. Proc. Natl. Acad. Sci. USA 82:8805-8809

92 Heidenreich F, Vincent A, Roberts A, Newsom-Davis J. (1988). Epitopes on human acetylcholine receptor defined by monoclonal antibodies and myasthenia gravis sera. Autoimmunity 1:285-297

93 Almon RR, Andrew CG, Appel SH. (1974). Serum globulin in myasthenia gravis: inhibition of $\alpha$-bungarotoxin binding to acetylcholine receptors. Science 186:55-57

94 Wilson PT, Lentz TL, Hawrot E. (1985). Determination of the primary amino acid sequence specifying the $\alpha$-bungarotoxin binding site on the $\alpha$-subunit of the acetylcholine receptor from Torpedo californica Proc. Natl. Acd. Sci. USA 82:8790-8794

95 Conti-Tronconi BM, Tang F, Diethelm BM, Spencer SR, Reihardt-Maelicke, Maelicke A. (1990). Mapping of a cholinergic binding site by means of synthetic peptides, monoclonal antibodies, and $\alpha$-bungarotoxin. Biochemistry. 29:6221-6230

96 Neumann D, Barchan D, Fridkin M, Fuchs S. (1986). Analysis of ligand binding to the synthetic dodecapeptide $185-196$ of the acetylcholine receptor $\alpha$-subunit. Proc. Natl. Acad. Sci. USA 83:9250-9253

97 Tzartos SJ, Remoundos MS. (1990). Fine localization of the major $\alpha$-bungarotoxin binding site to residues $\alpha .185-195$ of the acetylcholine receptor. Residues 189,190 , and 195 are indispensable for binding. J. Biol. Chem. 265:21462-21467 
98 McLarie KE, Wu XD, Diethelm B, Conti-Tronconi BM. (1991). Structural determinants of $\alpha$-bungarotoxin binding to the sequence segment 181-200 of the muscle nicotinic acetylcholine receptor $\alpha$-subunit: effects of cysteine/cystine modification and speciesspecific amino acid substitutions. Biochemistry 30:4925-4934

99 Griesmann GE, McCormick DJ, De Aizpurua HJ, Lennon VA. (1990). $\alpha$-bungarotoxin binds to human acetylcholine receptor $\alpha$-subunit peptide 185-199 in solution and solid phase but not to peptide 125-147 and 389-409. J. Neurochem. 54:1541-1547

100 Maelicke A, Plumer Wilk R, Fels G, Spencer SR, Engelhard M, Veltel D, Conti-Tronconi BM. (1989). Epitope mapping employing antibodies raised against short synthetic peptides: a study of the nicotinic acetylcholine receptor. Bicchemistry 28:1396-1405

101 Benjamin DC, Berzofsky JA, East IJ, Gurd FRN, Hannum C, Leach SJ, Margoliash E, Michael JG, Miller A, Prager EM, Reichlin M, Secarz EE, Smithgill SJ, Tod PE, Wilson AC. (1984). The antigenic structure of proteins: a reappraisal. Ann. Rev. Immunol. 2:67-101

102 Hohlfeld R, Toyka KV, Tzartos SJ, Carson W, Conti-Tronconi BM. (1987). Human T-helper lymphocytes in myasthenia gravis recognize the nicotinic receptor $\alpha$-subunit. Proc. Natl. Acad. Sci. USA 84:5379-5383

103 Fujii Y, Lindstrom J. (1988). Specificity of the T cell response to actylcholine receptor in experimental autoimmune myasthenia gravis. Response to subunits and synthetic peptides J. Immunol. 140:1830-1837

104 Zhang Y, Frutiger S, Hughes GJ, Savoy MC, Barkas T. (1990). Identification of autoantigens using recombinant proteins; studies on experimental autoimmune myasthenia gravis. Immunol. 71:538-543

105 Brocke S, Dayan M, Rothbard J, Fuchs S, Mozes E. (1990). The autoimmune response of different mouse strains to T-cell epitopes of the human acetylcholine receptor $\alpha$-subunit. Immunol. 69:495-500

106 Infante AJ, Thompson PA, Krolick KA, wall KA. (1991). Determinant selection in murine experimental autoimmune myasthenia gravis. Effect of the BM12 mutation on T cell recognition of acetylcholine receptor epitopes. J. Immunol. 146:2977-2982

107 Holfeld R, Toyka KV, Miner LL, Walgrave SL, Conti-Tronconi BM. (1988). Amphipathic segment of the nicotinic receptor alpha subunit contains epitopes recognized by $T$ lymphocytes in myasthenia gravis. J. Clin. Invest. 81:657-600

108 Protti MP, Manfredi AA, Straub C, Wu XD, Howard JF jr, Conti-Tronconi BM. (1990). Use of synthetic peptides to establish anti-human acetylcholine receptor CD4+ cell lines from myasthenia gravis patients. J. Immunol. 144:1711-1720

109 Protti MP, Manfredi AA, Straub C, Howard JF jr, Conti-Tronconi BM. (1990). Immunodominant regions for $T$ helper-cell sensitization on the human nicotinic receptor alpha subunit in myasthenia gravis. Proc. Natl. Acad. Sci. USA 87:7792-7796

110 Melms A, Chrestel S, Scalke BC, Wekerle H, Mauron A, Ballivet M, Barkas T. (1989). Autoimmune Tं lymphocytes in myasthenia gravis. Determination of target epitopes using $T$ lines and recombinant products of the mouse nicotinic receptor gene. J. Clin. Invest. 83:785-790

111 Oshima M, Ashizawa T, Pollack MS, Atassi MZ. (1990). Autoimmune T cell recognition of human acetylcholine receptor: the sites of $T$ cell recognition in myasthenia gravis on the extracellular part of the $\alpha$ subunit. Eur. J. Immunol. 20:2563-2569

112 Berrih-Aknin S, Cohen-Kaminsky S, Lepage V, Neumann D, Bach JF, Fuchs S. (1991). T-cell antigenic sites involved in myasthenia gravis: correlations with antibody titre and disease severity. J. Autoimmun. 4:137-153

113 Zhang Y, Schluep M, Frutiger S, Hughes GJ, Jeannet M, Steck A, Barkas T. (1990). Immunological heterogeneity of autoreactive T lymphocytes against the nicotinic acetylcholine receptor in myasthenic patients. Eur. J. Immunol. 20:2577-2583 
114 Newsom-Davis J, Hartcourt GH, Sommer N, Beeson D, Willcox N, Rothbard JB. (1989). T-cell reactivity in myasthenia gravis. J. Autoimmun. 2 (suppl.): 101-108

115 Hartcourt GC, Sommer N, Rothbard J, Willcox HN, Newsom-Davis J. (1988). A juxtamembrane epitope on the human acetylcholine receptor recognized by $T$ cells in myasthenia gravis. J. Clin. Invest. 82:1295-1300

116 Protti MP, Manfredi AA, Wu XD, Moiola L, Howard JF jr, Conti-Tronconi BM. (1991). Myasthenia gravis. T epitopes on the delta subunit of human muscle acetylcholine receptor. J. Immunol. 146:2253-2261

117 Protti MP, Manfredi AA, Howard JF jr, Conti-Tronconi BM. (1991). T cells in myasthenia gravis specific for embryonic acetylcholine receptor. Neurology 41:1809-1814

118 Ong B, Willcox N, Wordsworth P, Beeson D, Vincent A, Altmann D, Lanchburry JS, Hartcourt GC, Bell JI, Newsom-Davis J. (1991). Critical role for Val/Gly86 HLA-DR $\beta$ dimorphism in autoantigen presentation to human T cells. Proc. Natl. Acad. Sci. USA 88:7343-7347

119 Ralston S, Sarin V, Thanh HL, Rivie J, Fox JL, Lindstrom J. (1987). Synthetic peptides used to locate the $\alpha$-bungarotoxin binding site and immunogenic regions on $\alpha$ subunits of the nicotinic acetylcholine receptor. Biochemistry 26:3261-3266

120 Oosterhuis HJGH. (1984). Myasthenia gravis. In: Clinical Neurology and Neurosurgery monographs vol. 5, Glaser GH Ed., Churchill Livingstone. Edinburgh.

121 Walker M. (1934). Treatment of myasthenia gravis with physostigmine. Lancet I:12001201

122 Simpson JA. (1960). Myasthenia gravis: a new hypothesis. Scottish Med. J. 5:419-436

123 Nastuk WL, Plescia OJ, Osserman KE. (1960). Changes in serum cornplement activity in patients with myasthenia gravis. PSEBM 105:177-184

124 Engel AG, Santa T. (1971). Histometric analysis of the ultrastructure of the neuromuscular junction in myasthenia gravis and in the myasthenic syndrome. Ann. N.Y. Acad. Sci. 183:46-63

125 Fambrough DM, Drachman DB, Satyamurti S. (1973). Neuromuscular junction in myasthenia gravis: decreased acetylcholine receptors. Science 182:293-295

126 Lindstrom JM, Seybold ME, Lennon VA, Whittingham S, Duane DD. (1976). Antibody to acetylcholine receptor in myasthenia gravis. Neurology 26:1054-1059

127 Vincent A, Newsom-Davis J. (1978) Anti-acetylcholine receptor antibodies in D-penicillamine-associated myasthenia gravis. The lancet $1: 1254$

128 Vincent A. (1980). Immunology of acetylcholine receptors in relation to myasthonia gravis. Physiol. Rev. 60:756:824

129 Wray D. (1990). The Lambert-Eaton myasthenic syndrome in: Neuromuscular Transmission. basic and applied aspects. Vincent A, and Wray D, Eds. Manchester University Press, pp 249-267

130 Engel AG. (1990). Congenital myasthenic syndromes. In: Neuromuscular Tranısmission. basic and applied aspects. Vincent A, and Wray D, Eds. Manchester University Press, pp 200-225.

131 Engel AG. (1988). congenital myasthenic syndromes. J. Child Neurol. 3:233-246

132 Engel AG, Walls TJ, Nagel A, Uchitel O. (1990). Newly recognized congenital myasthenia syndromes: I. congenital paucity of synaptic vesicles and reduced quantal release. II. High conductance fast-channel syndrome. III. Abnormal acetylcholine receptor (AChR) interaction with acetylcholine IV. AChR deficiency and short channel-open time. Prog. Brain res. 84:125-137

133 Mora M, Lambert EH, Engel AG. (1987). Synaptic vesicle abnormality in familial infantile myasthenia. Neurology 37:206-214.

134 Sanders DB. (1987). The electrodiagnosis of myasthenia gravis. Ann. N. Y. Acad. Sci. 505:539-556 
135 Mossman S, Vincent A, Newsom-Davis J. (1986). Myasthenia gravis without acetycholine receptor antibody: a disctinct disease entity. Lancet I:116-118

136 Yamamoto T, Vincent A, Ciulla TA, Lang B, Johnston I, and Newsom-Davis J. (1991). Seronegative myasthenia gravis: A plasma factor inhibiting agonist-induced acetylcholine receptor function copurifies with IgM. Ann. Neurol. 30:550-557

137 Compston DAS, Vincent A, Newsom-Davis J, Batchelor JR. (1980). Clinical, pathological, HLA antigen and immunological evidence for disease heterogeneity in myasthenia gravis. Brain 102:579-601

138 Bell J, Smoot S, Newby C, Toyka K, Rassenti L, Smith K, Hohlfeld R, McDevit, Steinman L. (1986). HLA-DQ beta-chain polymorphism linked to myasthenia gravis. Lancet may 10:1058-1060

139 Degli-Esposti MA, Andreas A, Christiansen FT, Schalke B, Albert E, Dawkins RL. (1992). An approach to the localization of susceptibility genes for generalized myasthenia gravis by mapping recombinant ancestral haplotypes. Immunogenetics. 35:355-364

140 Vincent A, Whiting PJ, Schluep M, Heidenreich F, Lang B, Roberts A, Willcox N, Newsom-Davis J. (1987). Antibody, heterogeneity and specificity in myasthenia gravis. Ann. N.Y. Acad. Sci. 505:106-120

141 McGuire LJ, Huang DP, Teoh R, Arnold M, Wong K, Lee JCK. (1988). Epstein-Bar virus genome in thymoma and thymic lymphoid hyperplasia. Am. J. Pathol. 131:385-390

142 Klavinsky LS, Willcox NH, Richmond JE, Newsom-Davis J. (1986). Attempted isolation of viruses from myasthenia gravis thymus. J. Neuroimmunol. 11:287-299

143 Aoki T, Drachman DB, Asher DM, Gibbs CJ, Bahmanyar S, Wolinsky JS. (1985). Attempts to implicate virusses in myasthenia gravis. Neurology 35:135-192

144 Klavinsky LS, Willcox N, Oxford JS, Newsom-Davis J. (1985). Anti-virus antibodies in myasthenia gravis. Neurology 35:1381-1384

145 Stefansson K, Dieperink ME, Richman DP, Marton LS. (1987). Sharing of epitopes by bacteria and the nicotinic acetylcholine receptor: a possible role in the pathogenesis of myasthenia gravis. Ann. N.Y. Acad. Sci. 505:451-460

146 Dyrberg T, Petersen JS, Oldstone MB. (1990). Immunological cross-reactivity between mimicking epitopes on a virus protein and a human autoantigen depends on a single amino acid residue. Clin. Immunol. Immunopathol. 54:290-297

147 Dweyer DS, Vakil M, Bradley RJ, Oh SJ, Kearney JF. (1987). A possible cause of myasthenia gravis: idiotypic networks involving bacterial antigens. Ann. N.Y. Acad. Sci. 505:461-471

148 Schwimmbeck PL, Dyrberg T, Drachman DB, Oldstone MB. (1989). Molecular mimicry and myasthenia gravis. An autoantigenic site of the acetylcholine receptor $\alpha$-subunit that has biological activity and reacts immunochemically with herpes simplex virus. J. Clin. Invest. 84:1174-1180

149 Oldstone MBA. (1987). Molecular mimicry and autoimmune disease. Cell. 50:819-820

150 Manfredi AA, Bellone M, Protti MP, Conti-Tronconi BM. (1991). Molecular mimicry among human autoantigens. Immunol. Today 12:46-47

151 Bever C, Change H, Penn A, Jaffe I, Bock E. (1982). Penicillamine-induced myasthenia gravis: Effects of penicillamine on acetylcholine receptor. Neurology 32:1077

152 Kuncl RW, Pestronk A, Drachman DB, Rechthand E. (1986). The pathophysiology of penicillamine-induced myasthenia gravis. Ann. Neurol. 20:740-744

153 Smith Cl, Aarli JA, Biberfeld P, Bolme P, Christensson B, Gahrton G, Hammerstrom L, Lefvert AK, Lonnqvist B, Matell G. (1983). Myasthenia gravis after bone-marrow transplantation. Evidence for a donor origin. N. Eng. J. Med. 309:1565-1568

154 Bolger GB, Sullivan KM, Spence AM, Appelbaum FR, Johnston R, Sanders JE, Deeg HJ, Witherspoon RP, Doney KC, Nims J. (1986). Myasthenia gravis after allogenic bone marrow transplantation: relationship to chronic graft-versus-host disease. Neurology 36:1087-1091 
155 Wodzig KWH, Majoor GD, van Breda Vriesman PJC. (1991). On the localization of effector cells in cyclosporin-induced autoimmunity. Autoimmunity 10:275-283

156 Verschuuren JJGM, Bos GMJ, Majoor GD, De Beats MH, van Breda Vriesman PJC. (1989). Spontaneous myasthenia gravis in a rat after syngeneic bone marrow transplantation. (abstract). Proceedings of the 2nd European conference on myasthenia gravis. p. 33

157 Castleman B, and Norris EH. (1966). The pathology of the thymus gland in myasthenia gravis. Ann. N.Y. Acad. Sci. 135:496-503

158 Bofill M, Jannossy G, Willcox N, Chilosi M, Trejdosiewicz K, Newsom Davis J. (1985). Microenvironment in the normal thymus and the thymus in myasthenia gravis. Am J. Pathol. 119:462-473

159 Oosterhuis HJGH, Limburg PC, Hummel-Tappel E, van den Burg W, The TH. (1985). Anti-acetylcholine receptor antibodies in myasthenia gravis. III. The effect of thymectomy. J. Neurol. Sci. 69:335-343

160 Scadding GK, Vincent A, Newsom-Davis J, Henry K. (1981). Acetylcholine receptor synthesis by thymic lymphocytes: correlation with thymic histology. Neurology 31:935

161 Kao I, and Drachman DB. (1977). Thymic muscle cells bear acetylcholine receptors: possible relation to myasthenia gravis. Science 195:74-75

162 Schluep M, Willcox NH, Vincent A, Dhoot GK, Newsom-Davis J. (1987). Acetylcholine receptors in human myoid cells in situ: an immunohistochemical study. Ann. Neurol. 22:212-222

163 Kirchner T, Hoppe F, Schalke B, Müller-Hermelink HK. (1988). Microenvironment of thymic myoid cells in myasthenia gravis. Virch. Archiv. B cell Pathol. 54:395-402

164 Geuder KI, Marx A, Kirchner Th, Müller-Hermelink HK. (1992). Transcription of fetal and adult AChR types is found in thymitis, but not in thymomas of myasthenia gravis patients Myasthenia gravis and related disorders conference. Abstract pl-9

165 Geuder KI, Schoepfer R, Kirchner T, Marx A, Müller-Hermelink HK. (1989). The gene of the $\alpha$-subunit of the acetylcholine receptor: molecular organization and transcription in myasthenia-associated thymomas. Thymus 14:179-186

166 Hara Y, Ueno S, Uemichi T, Takahashi N, Yorifuji S, Fujii Y, Tarui S. (1991). Neoplastw epithelial celis express $\alpha$-subunit of muscle nicotinic acetylcholine receptor in thymomas from patients with myasthenia gravis. FEBS Lett. 279:137-140

167 Kirchner T, Tzartos S, Hoppe F, Schalke B, Wekerle H, Müller-Hermelink HK. (1988) Pathogenesis of myasthenia gravis. Acetylcholine receptor-related antigenic determinants in tumour-free thymuses and thymic epithelial tumours. Am J. Pathol. 130:268280

168 Sommer N, Willcox N, Hartcourt GC, Newsom-Davis J. (1990). Myasthenic thymus and thymoma are selectively enriched in acetylcholine receptor-reactive T cells. Ann. Neurol. 28:312-319

169 Vincent A. (1990). Myasthenia gravis an autoimmune disorder of neuromuscular transmission. In: Neuromuscular Transmission, basic and applied aspects. Vincent $A$, and Wray D, Eds. Manchester University Press, pp 226-248

170 Kuks JBM, Limburg PC, Oosterhuis HJGH, The TH. (1992). Antibodies to acetylcholine receptors in myasthenia gravis. In vitro synthesis by peripheral blood lymphocytes before and after thymectomy. Clin. Exp. Immunol. 87:246-250

171 Vincent A, Newsom-Davis J, Newton P, Beck N. (1983). Acetylcholine receptor antibody and clinical response to thymectomy in myasthenia gravis. Neurology 33:1276-1282

172 Kuks JBM, Oosterhuis HJGH, Limburg PC, The TH. (1992). Anti-acetylcholine receptor antibodies decrease after thymectomy in patients with myasthenia gravis. Clinical correlations. J. Autoimmun. 4:197-211 
173 Conti-tronconi BM, Scotti A, Sghirlanzoni A, Clementi F. (1983). Specific involvement of peripheral $T$ lymphocytes against acetylcholine receptors in myasthenia gravis. J. Neurol. Neurosurg. Psychiatry. 46:832-836

174 Benner R, Hejmans, Haajman JJ. (1981). The bone marrow: the major source of serum immunoglobulins, but still a neglected site of antiboy formation. Clin. Exp. Med. 46:1

175 Berman PW, Patrick J. (1980). Experimental myasthenia gravis. A murine system. J. Exp. Med. 151:204-233

176 Lennon VA, Lindstrom JM, and Seybold ME. (1975). Experimental autoimmune myasthenia gravis: a model of myasthenia gravis in rats and guinea pigs. J. Exp. Med. 141:1365-1375

177 Tarrab-Hazdai R, Aharonov A, Silverman I, Fuchs S, Abramsky O. (1975). Experimental autoimmune myasthenia gravis induced in monkeys by purified acetylcholine receptor. Nature 256:128-130

178 Lindstrom J, Shelton D, Fujii Y. (1988). Myasthenia gravis. Adv. Immunol. 42:233-284

179 Lindstrom JM, Engel AG, Seybold ME, Lennon VA, Lambert EH. (1976). Pathological mechanisms in experimental autoimmune myasthenia gravis in rats with anti-acetylcholine receptor antibodies. II. Passive transfer of experimental autoimmune myathenia gravis in rats with anti-acetylcholine receptor antibodies J. Exp. Med. 144:739-753

180 Lindstrom JM, Einarson BL, Lennon VA, Seybold ME. (1976). Pathological mechanisms in experimental autoimmune myasthenia gravis. I. Immunogenicity of syngeneic muscle acetylcholine receptor and quantative extraction of receptor and antibody-receptor complexes from muscles of rats with experimental autoimmune myasthenia gravis. J. Exp. Med. 144:726-728

181 Einarson B, Gullick W, Conti-Tronconi B, Ellisman M, Lindstrom J. (1982) Subunit composition of bovine muscle acetylcholine receptor. Biochemistry 21:5295-5302

182 Lindstrom J, Cambell M, Nave B. (1978). Specificities of antibodies to acetylcholine receptors. Muscle and Nerve 1:140-145

183 Lindstrom J. (1979). autoimmune response to acetylcholine receptors in myasthenia gravis and its animal model. Adv. Immunol. 27:1-50

184 Engel AG, Tsujihata M, Lambert EH, Lindstrom J, Lennon V. (1976). Experimental autoimmune myasthenia gravis: A sequential and quantitative study of the neuromuscular junction ultrastructure and electrophysiologic correlations. J. Neuropath. Exp. Neurol. 35:569-587

185 Engel A, Tsujihata M, Lindstrom J, Lennon V. (1976) The motor end plate in myasthenia gravis and experimental autoimmune myasthenia gravis. Ann. N.Y. Acad. Sci. 274:60-79

186 Scadding GK, Calder L, Vincent A, Prior C, Wray D, Newsom-Davis J. (1986). Anti-acetylcholine receptor antibodies induced in mice by syngeneic receptor without adjuvants. Immunol. 58:151-155

187 Jermy A, Vincent A, Beeson D, Newsom-Davis J. (1992). EAMG induced in mice by injection of syngeneic purified acetylcholine receptor. Myasthenia gravis and related disorders conference. Abstract plll-10

188 Jermy A, Fisher C, Vincent A, Willcox N, Newsom-Davis J. (1989). Experimental autoimmune myasthenia gravis induced in mice without adjuvants: genetic susceptibility and adoptive transfer of weakness. J. Autoimmunity 2:675-688

189 Lindstrom JM, Einarson B, Merlie J. (1978)) Immunization of rats with polypeptide chains from Torpedo acetylcholine receptor causes an autoimmune response to receptors in rat muscle. Proc. Natl. Acad. Sci. USA 75:769-773

190 Lennon VA, Griesmann GA, McCormick DJ, Huang Z-X, Feng H, Lambert EH. (1987). Definition of myasthenogenic sites of the human acetylcholine receptor using synthetic petides. Ann N. Y. Acad. Sci. USA 505:439-450 
191 McCormick DJ, Griesmann GE, Huang Z-X, Lambert EH, Lennon VA. (1987). Myasthenogenicity of human acetylcholine receptor synthetic $\alpha$ subunit peptide 12.5-147 does not require intramolecular disulfide cyclization. J. Immunol. 139:2615-2619

192 Takamori M, Okumura S, Nagata M, Yoshikawa H. (1988). Myasthenogenic significance of synthetic $\alpha$-subunit peptide $183-200$ of Torpedo californica and human acetylcholine receptor. J. Neurol. Sciences 85:121-129

193 Lennon VA, Lambert EH, Leiby KR, Okarma TB, Talib S. (1991). Recombinant human acetylcholine receptor $\alpha$-subunit induces chronic experimental autoimmune myasthenia gravis. J. Immunol. 146:2245-2248

194 Neumann D, Gershoni JM, Fridkin M, Fuchs S. (1985). Antibodies to synthetic peptides as probes for the binding site on the $\alpha$-subunit. Proc. Natl. Acad. Sci. USA 83:9250-9253

195 Criado M, Sarin V, Fox JL, Lindstrom J. (1986). Evidence that the acetylcholine binding site is not formed by the sequence $\alpha 127-143$ of the acetylcholine receptor. Biochemistry 25:2839-2846

196 Barkas T, Mauron A, Roth B, Alloid C, Tzartos SJ, Ballivet M. (1987). Mapping of the main immunogenic region and toxin-binding site of the nicotinic acetylcholine receptor. Science 235:77-80

197 Jermy A, Fisher C, Vincet A, Willcox N, Newsom-Davis J. (1989). Mice immunised with recombinant $\alpha$ subunit of the human acetylcholine receptor develop anti-AChR antibodies but no experimental autoimmune myasthenia gravis. J. Autoimmun. 2:903-904 (abstract)

198 Toyka KV, Drachman DB, Pestronk A, Kao I. (1975). Myasthenia Gravis: Passive transfer from man to mouse. Science 190:397-399

199 Richman DP, Gomez CM, Berman PW, Burres SA, Fitch FW, Arnason BG.(1980). Monoclonal anti-acetylcholinereceptor antibodies can cause experimental myasthenia. Nature 286:738-739

200 Gomez CM, Richman DP. (1983). Monoclonal anti-acetylcholine receptor antibodies with differing capacities to induce experimental autoimmune myasthenia gravis. J. Immunol. 135:234-241

201 Tzartos SJ, Hochschwender S, Vasquez P, Lindstrom J. (1987). Passive transfer of experimental autoimmune myasthenia gravis by monoclonal antibodies to the main immunogenic region of the acetylcholine receptor. J. Neuroimmunol. 15:185-194

202 Gomez CM, Wollman RL, Richman DP. (1984). Induction of morphologic changes of both acute and chronic experimental myasthenia by monoclonal antibody directed against acetylcholine receptor. Acta Neuropathol. 63:131-143

203 Corey AL, Richman DP, Shuman CA, Gomez CM, Arnason BGW. (1985). Use of monclonal anti-acetylcholine receptor antibodies to investigate the macrophage inflammation of acute experimental myasthenia gravis. Neurology 35:1455-1460

204 Engel A, Sakakibara H, Sahashi K, Lindstrom J, Lambert E, Lennon VA. (1978). Passively transferred experimental autoimmune myasthenia gravis. Neurology 29:179-188

205 Gomez C, Richman DP. (1987). Chronic experimental autoimmune myasthenia gravis induced by monoclonal antibody to acetylcholine receptor: biochemical and electrophysiologic criteria. J. Immunol. 139:73-76

206 Biesecker F, Koffler D. (1988). Resistance to experimental autoimmune myasthenia gravis in genetically inbred rats. J. Immunol. 140:3406-3410.

207 Christados P, Lindstrom J, Munro S, Tala N. (1985). Muscle acetylcholine receptor loss in murine experimental autoimmune MG: correlated with cellular, humoral and clinical responses. J. Immunol. 8:29-41.

208 Fuchs S, Nevo D, Tarrab-Hazdai R. (1976). Strain differences in the autoimmune response of mice to acetylcholine receptors. Nature 263:329-330 
209 Berman PW, Patrick J. (1980). Linkage between the frequency of muscular weakness and loci that regulate immune responsiveness in murine experimental myasthenia gravis. J. Exp. Med. 152:507-520

210 Christadoss P. (1988). C5 gene influences the development of murine myasthenia gravis. J. Immunol. 140:2589-2592

211 Christadoss P, Lennon VA, Hrco CJ, David CS. (1982). Genetic control of experimental autoimmune $M G$ in mice. II. la molecules mediate cellular immune resposiveness to acetylcholine receptors. J. Immunol. 128:1141-1144

212. Christadoss P, Lindstrom JM, Melvold RW, Talal N. (1985). Mutation at the I-A $\beta$ chain prevents experimental autoimmune myasthenia gravis. Immunogenetics. 21:33-38

213 Seybold ME, Lambert EH, Lennon VA, Lindstrom JM. (1976). Experimental autoimmune myasthenia gravis: clinical, neurophysiologic and pharmacologic aspects. Ann. N.Y. Acad. Sci. 274:275-282

214 Heilbronn E, Mattson C, Thornell L-E, Sjöström MM, Stålberg E, Hilton-Brown P, Elmqvist D. (1976). Experimental myasthenia gravis in rabbits: biochemical, immunological, electrophysiological, and morphological aspects. Ann. N.Y. Acad. Sci. 274:337-353

215 Verschuuren JJGM, Spaans F, De Baets MH. (1989). Single fiber electromyography in experimental autoimmune myasthenia gravis. Muscle and Nerve 13:285-292

216 Engel AG, Sakakibara H, Sahashi K, Lindstrom JM, Lambert EH, Lennon VA. (1979). Passively transferred experimental autoimmune myasthenia gravis. Sequential and quantative study of the motor endplate fine structure and ultrastructural localization of immune complexes ( $\operatorname{lgG}$ and C3), and of the acetylcholine receptor. Neurology 29:179188

217 Toyka KV, Löwenadler B, Heiniger K, Besinger KA, Birnberger KL, Fateh-Moghadam A, Heilbron E. (1980). Passively transferred myasthenia gravis: protection of mouse endplates by fragments from human myasthenia gravis IgG. J Neurol. Neurosurg. Psych. 43:836-842

218 Donaldson JO, Penn AS, Lisak RP, Abramsky O, Brenner T, Schotland DL. (1981). Anti-Acetylcholine receptor antibody in neonatal myasthenia gravis. Am. J. Dis. Child. 135:222-226

219 Eymard B, Vernet der Garabedian B, Berrih-Aknin S, Pannier C, Bach JF, Morel E. (1991). Anti-acetylcholine receptor antibodies in neonatal myasthenia gravis: heterogeneity and pathogenic significance. J. Autoimmunity 4:185-195

220 Dau PC, Lindstrom JM, Cassel CK, Denys EH, Shev EE, Spitler LE. (1977). Plasmaphoresis and immunosuppressive drug therapy in myasthenia gravis. N. Eng. J. Med. 297:1134-1140

221 Newsom-Davis J, Pinching AJ, Vincent A, Wilson SG. (1978). Function of circulating antibody to acetylcholine-receptor in myasthenia gravis invesigated by plasma exchange. Neurology 28:266-272

222 Pinching AJ, Pelers DK, Newsom-Davis J. (1976). Remmission of myasthenia gravis following plasma exchange. Lancet II:1373-1376

223 Kao I, Drachman DB. (1977). Myasthenic immunoglobulin accelerates acetylcholine receptor degradation. Science 196:527-529

224 Drachman DB, Angus CW, Adams RN, Michelson JD, Hoffman GJ. (1978). Myasthenic antibodies cross-link acetylcholine receptors to accelerate degradation. N. Eng. J. Med. 298:1116-1122

225 Appel SH, Anwyl R, McAdams MW, Elias S. (1977). Accelerated degradation of acetylcholine receptor from cultured rat myotubes with myasthenia gravis sera and globulins. Proc. Natl. Acad. Sci. USA 74:2130-2134

226 Ashizawa T, Elias SB, Appel SH. (1982). Interaction of myasthenic immunoglobulins andcholinergic agonists on acetylcholine receptors of rat myotubes. Ann. Neurol. 11:22-27 
227 Heineman S, Merlie J, Lindstrom J. (1978). Modulation of acetylcholine receptor in rat diaphragm by anti-receptor sera. Nature 274:65-68

228 Sher E, Clementi F. (1984). Effect of specific antibodies on acetylcholine receptor turnover: increased degradation controles low density of cell surface receptor. Neurology 34:208-211

229 Heineman S, Bevan R, Kullberg J, Lindstrom J, Rice J. (1977). Modulation of acetylcholine receptor by antibody against the receptor. Proc. Natl. Acad. Sci. USA 74:3090-3094

230 Lindstrom J, Einarson B. (1979). Antigenic modulation and receptor loss in experimental autoimmune myasthenia gravis. Muscle and Nerve. 2:172-179

231 Merlie JP, Heinemann S, Lindstrom JM. (1979). Acetylcholine receptor degradation in adult rat diaphragms in organ culture and the effect of anti-acetylcholine receptor antibodies. J. Biol. Chem. 254:6320-6327

232 Tzartos SJ, Starzinski-Powitz A. (1986). Decrease in acetylcholine-receptor content of human myotube cultures mediated by monoclonal antibodies to $\alpha, \beta$ and $\gamma$ subunits. FEBS Lett. 196:91-95

233 Tzartos SJ, Sophianos D, Zimmerman K, Starzinski-Powitz A. (1986). Antigenic modulation of human myotube acetylcholine receptor by myasthenic sera. Serum titer determines receptor internalization rate. J. Immunol. 136:2131-3238

234 Sophianos D, Tzartos SJ. (1989). Fab fragments of monoclonal antibodies protect the human acetylcholine receptor against antigenic modulation caused by myasthenic sera. J. Autoimmun. 2:777-789

235 Conti-Tronconi B, Brigonzi A, Fumagalli G, Sher M, Cosi V, Piccolo G, Clementi F. (1981). Antibody induced degradation of acetylcholine receptor in myasthenia gravis: clinical correlates and pathogenetic significance. Neurology 31:1440-1444

236 Eymard B, de la Porte S, Pannier C, Berrih-Aknin S, Morel E, Fardeau M, Bach JF, König J. (1988). Effect of myasthenic sera on the number and distribution of acetylcholine receptors in muscle and nerve-muscle cultures from rat. correlations with clinical state. J. Neurol. Sci. 86:41-59

237 Drachman DB, Robert RN, Josifek LF, Self SG. (1982). Functional activities of autoantibodies to the acetylcholine receptors and the clinical severity of myasthenia gravis. N. Eng. J. Med. 307:769-775

238 Hudgson P, McAdams MW, Pericak-Vance MA, Edwards AM, Roses AD. (1982). Effect of sera from myasthenia gravis patients on acetylcholine receptors in myotube cultures. J. Neurol. Sci. 59:37-45

239 Bevan S, Kullberg RW, Heinemann. (1977). Human myasthenic sera reduce acetylcholine sensitivity of human muscle cells in tissue culture. Nature 267:263-265

240 Tzartos SJ, Sophianos D, Efthimiados A. (1985). Role of the main immunogenic region of acetylcholine receptor in myasthenia gravis. An Fab monoclonal antibody protects against antigenic modulation by human sera. J. Immunol. 134:2343-2349

241 Kinoshita T. (1991). Biolology of complement: the overture. Immunol. Today. 12:291-295

242 Engel AG, Lambert EH, Howard FM. (1977). Immune complexes (IgG and C3) at the motor endplate in myasthenia gravis. Ultratructural and light microscopic localization and electrophysiologic correlations. Mayo clin. proc. 52:267-280

243 Sahashi K, Engel AG, Lambert EH, Howard FM. (1980). Ultrastructural localization of the terminal and lytic nith complement component (C9) at the motor endplate in myasthenia gravis. J. Neuropathol. Exp. Neurol. 37:213-233

244 Childs LA, Harrison R, Lunt GG. (1985). Complement dependent toxicity of serum from myasthenic patients to muscle cells in culture. J. Neuroimmunol. 9:69-80

245 Ashizawa T, Appel SH. (1985). Complement-mediated lysis of cultured rat myotubes by myasthenic immunoglobulins. Neurology 35:1748-1753 
246 Sahashi K, Engel AG, Lindstrom JM, Lambert EH, Lennon VA. (1978). Ultrastructural localization of immune complexes ( $\mathrm{gG}$ and C3) at the endplate in experimental autoimmune myasthenia gravis. J. Neuropath. Exp. Neurol. 37:213-233

247 De Baets M. (1990). Experimental autoimmune myasthenia gravis. In: Neuromuscular Transmission. basic and applied aspects. Vincent A, and Wray D, Eds. Manchester University Press, pp 268-288

248 Lennon VA, Lambert AH. (1981). Monoclonal antibodies to acetylcholine receptors: evidence for a dominant idiotype and requirement of complement for pathogenicity. Ann. N. Y. Acad. Sci. 377:77-96

249 Lennon VA, Seybold ME, Lindstrom JM, Cochrane C, Ulevitch R. (1978). Role of complement in the pathogenesis of experimental autoimmune myasthenia gravis. J. Exp. Med. 147:973-983

250 Biesecker G, Gomez CM. (1989). Inhibition of acute passive transfer experimental autoimmune myasthenia gravis with Fab antibody to complement C6. J. Immunol. 142:2654-2659

251 Cleveland WL, Wasserman NH, Sarangarajan R, Penn AS, Erlanger BF. (1983). Monoclonal antibodies to the acetylcholine receptor by a normally functioning auto antiidiotypic mechanism. 305:56-57

252 Donnelly A, Mihovilovic M, Gonzalez-Ros JM, Ferragut JA, Richman D, Martinez-Carrion M. (1984). Noncholinergic site-directed monoclonal antibody can impair agonist-induced ion flux in Torpedo californica acetylcholine receptor. Proc. Natl. Acad. Sci. USA 81:7999-8003

253 Sanders DB, Kim YI, Howard JF, Johns TR, Muller WH. (1981). Intercostal muscle biopsy studies in myasthenia gravis: clinical correlations and the direct effects of drugs and myasthenic serum. Ann. N.Y. Acad. Sci. 377:544-566

254 Schuetze SM, Vicini S, Hall ZW. (1985). Myasthenic serum selectively blocks acetylcholine receptors with long channel open times at developing rat endplates. Proc. Natl. Acad. Sci. USA 82:2533-2537

255 Shibuya N. (1978). Serum factor blocks neuromuscular transmission in myasthenia gravis: electrophysiologic study with intracellular microelectrodes. Neurology 28:804811

256 Fulpius BW, Lefvert AK, Cuénoud S, Mourey A. (1981). Properties of specific populations of anti-acetylcholine receptor antibodies in myasthenia gravis. Ann. N.Y. Acad. Sci. 377:307-315

257 Mittag TW, Xu X, Moshoyiannis H, Kornfeld P, Genkins G. (1984). Analysis of false negative results in the immunoassy for anti-acetylcholine receptor antibodies in myasthenia gravis. Clin. Immunol. Immunopathol. 31:191-201

258 Whiting PJ, Vincent A, Newsom-Davis J. (1983). Acetylcholine receptor antibody characteristics in myasthenia gravis. Fractionation of $\alpha$-bungarotoxin binding site antibodies and their relationship to IgG subclass. J. Neurol. 5:1-9

259 Bessinger UA, Toyka KV, Homberg M, Heininger K, Hohlfeld R, Fateh Moghadam. (1983). Myasthenia gravis: long-term correlation of binding and bungarotoxin blocking antibodies against acetylcholine receptors with changes in disease severity. Neurology 33:1316-1321

260 Vernet der Garabedian B, Morel E, Bach JF. (1986). Heterogeneity of antibodies directed against the $\alpha$-bungarotoxin binding site on human acetylcholine receptor and severity of myasthenia gravis. J. Neuroimmunol. 12:65-74

261 Pachner AR. (1989). Anti-acetylcholine receptor antibodies block bungarotoxin binding to native human acetylcholine receptor on the surface of TE671 cells. Neurology 39:1057-1061 
262 Vernet der Garabedian B, Bach JF, Morel E. (1987). Protective effect of myasthenic immunoglobulins against lethal toxicity of $\alpha$-bungarotoxin. Clin. Exp. Immunol. 68:130137

263 Bender AN, Engel WK, Ringel SP, Daniels MP, Vogel Z. (1975). Myasthenia gravis: a serum factor blocking acetylcholine receptors of the human neuromuscular junction. Lancet I: 607-609

264 Lang B, Richardson G, Rees J. (1988). Plasma from myasthenia gravis patients reduces acetylcholine receptor agonist-induced $\mathrm{Na}^{+}$flux into TE671 cell line $\mathrm{J}$. Neuroimmunol. 19:141-148

265 Verschuuren JJGM, Graus YMF, Theunissen ROM, Yamamoto T, Vincent A, van BredaVriesman PJC, De Baets MH. (1992). Role of acetylcholine receptor antibody complexes in muscle in experimental autoimmune myasthenia gravis. J. Neuroimmunol. 36: 117-125

266 Fuchs S. (1979). Immunology of the nicotinic acetylcholine receptor. Curr. Top. Microbiol. Immunol. 85:1-29

268 Christadoss P. (1989). Immunogenetics of experimental autoimmune myasthenia gravis. Crit. Rev. Immunol. 9:247-278

269 Tsujihata M, Hazama R, Ishii N, Ide Y, Mori N, Takamori M. (1979). Limb muscle endplates in ocular myasthenia gravis: quantative ultrastructural study. Neurology 29:654-661

270 Engel AG, Sahashi K, Fumagalli G. (1981). The immunopathology of aquired myasthenia gravis. Ann. N.Y. Acad. Sci. 377:158-174

271 Pascuzzi RM, Campa JF. (1988). Lymporrhage localized to the muscle endplate in myasthenia gravis. Arch. Pathol. Lab. Med. 112:934-937

272 Maselli RA, Richman DP, Wollman RL. (1991). Inflammation at the neuromuscular junction in myasthenia gravis. Neurology 41:1497-1504

273 Pachner AR, Konator FS, Mulac-Jericevic B, Atassi MZ. (1989). An immunodominant site of acetylcholine receptor in experimental myasthenia mapped with $T$ lymphocyte clones and synthetic peptides. Immunol. Lett. 20:199-204 


\section{Chapter 2}

\section{Age related resistance to experimental autoimmune myasthenia gravis in rats}

Yvo M.F. Graus, Jan J.G.M. Verschuuren, Frank Spaans, Frans Jennekens, Peter J.C. van Breda Vriesman and Marc H. De Baets. 


\section{Age related resistance to experimental autoimmune myasthenia gravis in rats}

\section{ABSTRACT}

The influence of age on the induction of experimental autoimmune myasthenia gravis (EAMG) was investigated. Immunization with acetylcholine receptor $(A C h R)$ or injection of varying amounts of anti-AChR mAb 35 into young adult (10-12 wk) BN rats induced severe signs of EAMG including weight loss and decrement of muscle action potential, whereas aged BN rats (120-130 wk) did not show any clinical or electrophysiological signs of EAMG. Serum anti-AChR $m A b$ titers were not significantly different in young and aged rats up to $24 \mathrm{hrs}$ after administration of mAb. No significant AChR loss was demonstrated in aged rats, whereas similar treated young rats showed extensive AChR loss. In contrast to young rats, no degradation of the postsynaptic membrane could be demonstrated by electron microscopy in aged rats. Complement component C3 could be demonstrated at the neuromuscular junction in both young and aged mAb treated rats. However, infiltrating macrophages and necrotic muscle fibers were only seen in young rats. These results suggest that the postsynaptic membrane in aged rats is resistant to autoantibody attack. AChR degradation by antigenic modulation may be less efficient in aged rats as a result of altered AChR density and distribution or rigidity of the postsynaptic membrane. Age related resistance in the EAMG model can provide more information about the factors that determine the severity of myasthenia gravis (MG). Manipulation of AChR density or lipid compostion of the postsynaptic membrane may be of therapeutic interest in MG. 


\section{INTRODUCTION}

Myasthenia gravis is an autoimmune disease in which antibodies to the acetylcholine receptor result in a defective neuromuscular transmission. Clinica! symptoms characteristic for myasthenia gravis can be induced in experimental animals by immunization with $\mathrm{AChR}(1)$ or passive transfer of polyclonal $(2,3)$ or monoclonal anti-AChR antibodies (4-7). Passive transfer of anti-AChR antibody brings about muscular weakness and excessive fatigue reaching a maximum at $48 \mathrm{hrs}$ after injection, and disappears after one week. Three main pathogenic mechanisms contribute to the degradation of AChRs at the neuromuscular junction (NMJ). I Anti-AChR antibodies cross-link AChRs resulting in an increased internalization of $\mathrm{AChRs}$ by antigenic modulation (8). II Activation of complement results in destruction of the postsynaptic membrane by focal lysis (9). Furthermore, in acute and passive transfer EAMG, complement components attract macrophages that sequester remnants of the postsynaptic membrane and cause disruption of the NMJ (10). III Inactivation of AChR function by interference of antibody with ligand binding $(10,11)$ or ion channel function (12). These pathogenic mechanisms lead to AChR loss and simplification of the highly folded postsynaptic membrane.

This study investigates the influence of age on the induction of experimental autoimmune myasthenia gravis in the rat by immunization with Torpedo AChR or passive transfer of anti-AChR mAb 35 to young adult and aged BN rats. Aged rats in contrast to young rats appeared to be resistant to induction of both chronic and passive transfer EAMG.

Several parameters were studied in order to explain the observed resistance to induction of passive transfer EAMG. Resistance to induction of EAMG in aged rats could not be attributed to differences in antibody uptake or clearance. Complement was activated at motor endplates of both young and aged rats, but segmental muscle necrosis and infiltration of macrophages at motor endplates could only be demonstrated in severly affected young rats. These results suggest that complement mediated lysis of the postsynaptic membrane is not sufficient to induce EAMG and antigenic modulation of AChR may be less effective in aged rats as a consequence of age dependend changes in AChR density or fluidity of the postsynaptic membrane.

\section{MATERIAL AND METHODS}

\section{Animals}

Inbred 10-12 week old male and female Brown Norway rats were obtained from the the breeding colonies of the Department of Experimental Animal Services of the University of Limburg or from TNO, Rijswijk, The Netherlands. All animals were bred under specific pathogen tree conditions.

\section{Induction of chronic experimental autoimmune myasthenia gravis}

Rats were immunized at the base of the tail with $10 \mu \mathrm{g} / 100 \mathrm{gr}$ bodyweight Torpedo AChR emulsified in CFA. Rats were boosted with $10 \mu \mathrm{g} / 100 \mathrm{gr}$ Torpedo AChR in IFA 6 weeks after primary immunization. 


\section{Induction of passive transfer experimental autoimmune myasthenia gravis}

Rats were injected intraperitoneal with ascitic fluid or culture supernatant containing rat anti-AChR mAb 35 (a kind gift of Dr. S.J. Tzartos, Institute Pasteur Helenique, Athens. Greece). Control rats were injected with an equal amount of normal rat serum. MAb 35 is a rat mAb directed to the main immunogenic region on the $\alpha$-subunit of the AChR (7). Rats were injected with a mAb 35 dose having a AChR binding capacity of 20 or $60 \mathrm{pmol}$ rat $\mathrm{AChR} / 100$ grams bodyweight.

\section{Determination of anti-rat AChR antibody titers}

Antibody titers against rat AChR ( $\mathrm{ACChR}$ ) were measured by immunoprecipitation using ${ }^{125} \mid$ - $\alpha$-bungarotoxin $\left({ }^{125} \mid-\alpha\right.$-BT) labeled rAChR according to Lindstrom et al (13) with minor modifications. Briefly, a crude extract of denervated rat muscle AChR (approximately $0.6 \mathrm{nmol} / \mathrm{l}$ ) was labeled with $2 \times 10^{-9} \mathrm{M} 125 /-\alpha$-BT for 4 hrs at 4 ${ }^{\circ} \mathrm{C}$. A dilution range of serum samples $(5 \mu \mathrm{l})$ were incubated with $200 \mu$ labeled rAChR overnight at $4^{\circ} \mathrm{C}$. Antibody-AChR complexes were precipitated by adding excess goat-anti-rat IgG antibodies. After $4 \mathrm{hrs}$ at $4{ }^{\circ} \mathrm{C}$, samples were centrifuged for $3 \mathrm{~min}$ in an Eppendorf centrifuge and subsequently washed once with $1 \mathrm{ml}$ PBS buffer containing $0.5 \%$ Triton-X100 (Sigma, Brunschwig chemie b.v., Amsterdam, The Netherlands) and $0.02 \% \mathrm{NaN}_{3}$ (PBS/TX). Radioactivity was counted in a gamma counter (Compugamma, Pharmacia LKB, Woerden, The Netherlands). Values of ${ }^{125} \mid-\alpha-B T-r A C h R$ pelleted in the presence of normal rat serum were considered background and substracted from the assay values. The antibody titers were expressed as moles of $125 /$ - $\alpha$-BT binding sites per liter.

\section{Determination of antibody clearance}

The clearance of antibody from the circulation of young and aged rats was determined using ${ }^{131} \mathrm{l}$ labeled $\operatorname{lgG}\left({ }^{131} \mathrm{l}-\mathrm{IgG}\right)$. Three days prior to injection of ${ }^{131 /-} \mathrm{lgG}$, the drinking water supplied to the rats was supplemented with $0.1 \% \mathrm{w} / \mathrm{V} \mathrm{KI}$ to prevent $131 \mathrm{l}$-IgG uptake in the thyroid glands. ${ }^{131} \mathrm{l}$-IgG was injected intravenously into the tail vein and blood samples were taken $0.25,5,24,48$ and 72 hrs after administration. The clearance of $131 \mathrm{l} / \mathrm{lgG}$ was expressed as the percentage of remaining radioactivity at several points in time after administration. The amount of ${ }^{131} \mathrm{l}$-IgG measured $15 \mathrm{~min}$ after i.v. administration was considered $100 \%$.

\section{Quantitation of AChR and antibody-AChR complexes in muscle}

The concentration of AChR and antibody-AChR complexes was determined in whole carcasses according to Lindstrom et al (13) with modifications as previously described (14). The AChR concentration in muscle was expressed as pmol AChR/100 gr muscle. Antibody-AChR complexes were expressed as the $\%$ of the total AChR concentration.

\section{Electromyographic evaluation}

The decrement of the compound muscle action potential (CMAP) was determined in the gluteus medius muscle $48 \mathrm{hrs}$ after administration of mAb 35. Rats were anaesthetized with $800 \mu \mathrm{l} / \mathrm{kg}$ ketamine (Nimatek). The body temperature during measurements was monitored with a thermal probe and the skin temperature was maintained at $33-35^{\circ} \mathrm{C}$ by means of an infrared heating lamp (DISA, Copenhagen, 
Denmark). Nerve stimulation and recording of CMAP was performed using monopolar teflon coated steel needles with a $0.8 \mathrm{~mm}$ bare tip. The recording electrodes were placed subcutaneously, one over the belly and the other in the distal tendon region of the gluteal muscle. The CMAP was recorded in response to supramaximal stimuli applied through needle electrodes to the superior gluteal nerve. In a pilot study in myasthenic rats we found decrement to be more pronounced with stimulation at $10 \mathrm{~Hz}$ than at 3 or $5 \mathrm{~Hz}$, Therefore, $10 \mathrm{~Hz}$ stimulation was used in the present study. During each test 7 stimuli of $0.2 \mathrm{~ms}$ were given. The results of triplicate series were averaged and a positive decremental response was defined as an amplitude decrease of more than $10 \%$ of the fifth response compared to the first response $(15,16,17)$. Measurements were performed with a Viking EMG machine (Nicolet Biomedical Instruments, Madison, WI, U.S.A.).

\section{Electron microscopy of neuromuscular junction}

Muscle biopsies taken from young and aged rats $48 \mathrm{hrs}$ after administration of mAb 35 were fixed in Periodate-Lysine-Paraformaldehyde for 90 min at $4^{\circ} \mathrm{C}$. Cryosections were fixed in $1 \%$ osmium tetroxide for $60 \mathrm{~min}$ at room temperature (R.T.), dehydrated and embeded in epon 812 . Ultrathin sections from regions with endplates were contrasted with uranyl acetate and lead citrate. Endplates were viewed using a Zeis 109 electron microscope.

\section{Localization of $\mathrm{C3}$}

Deposition of complement at endplates was determined in cryosections of muscie biopsies taken from young and aged rats $48 \mathrm{hrs}$ after administration of $20 \mathrm{pmol} / 100$ gr bodyweight mAb 35 or normal rat serum. Cryosections were aceton fixed for 10 $\mathrm{min}$ at $4^{\circ} \mathrm{C}$ and air dried for $5 \mathrm{~min}$. After 3 washes with PBS, the sections were preincubated with PBS containing $2 \%$ bovine serum albumin for $15 \mathrm{~min}$ and subsequently incubated with polyclonal rabbit-anti-rat C3 antibodies together with rhodamine labeled $\alpha$-BT (Molecular Probes, Eugene, OR USA.) for $1 \mathrm{hr}$ at R.T. . After 3 washes with PBS, sections were incubated with FITC conjugated swine-anti-rabbit antibodies for $1 \mathrm{hr}$ to visualize bound anti-C3 antibodies.

\section{Detection of macrophages}

Muscle sections were stained for macrophages using mAb ED 1(18). Bound ED 1 was visualized using FITC labeled goat-anti-mouse Ig (Cappel, Organon Technika, Boxtel, The Netherlands). AChR was localized in the same section by co-incubation with rhodamine labeled $\alpha$-BT.

\section{Statistical analysis}

The students T-test and the Wilcoxon rank test were used for statistical analysis. 


\section{RESULTS}

\section{Induction of chronic EAMG in young and aged rats}

To investigate the influence of age on the development of EAMG we induced EAMG in young adult (10-12 wk) and aged (120-130 wk) old rats by immunization with Torpedo AChR. Ten weeks after primary immunization both young and aged rats developed a similar antibody titer against rAChR (table I). At this point in time 9 out of 10 young rats showed muscular weakness and showed a mean AChR loss of $57 \pm 2 \%$. In contrast, aged rats showed no muscular weakness or AChR loss (table 1).

Table l: Aged rats are resistant to induction of chronic EAMG

\begin{tabular}{|c|c|c|c|c|c|c|}
\hline Rat group & Age & $N$ & $\begin{array}{l}\text { Ab titer }{ }^{a} \\
\mathrm{nmol} / /\end{array}$ & $\begin{array}{l}{[\mathrm{AChR}]^{\mathrm{b}}} \\
\mathrm{pmol} / 100 \mathrm{gr} \\
\text { muscle }\end{array}$ & $\begin{array}{l}\text { AChR lossC } \\
\%\end{array}$ & $\begin{array}{l}A C h R-A b^{d} \\
\%\end{array}$ \\
\hline young & $12 w k$ & 10 & $23 \pm 4$ & $24 \pm 1$ & $57 \pm 2$ & $37 \pm 4$ \\
\hline aged & $125 w k$ & 10 & $26 \pm 9$ & $52 \pm 5$ & $1 \pm 10$ & $32 \pm 6$ \\
\hline
\end{tabular}

The mean antibody titer against $r A C h R$, the total AChR concentration and the fraction of AChR complexed with antibody was determined 10 weeks after initial immunization with Torpedo AChR. Rats were immunized with $10 \mu \mathrm{g}$ Torpedo AChR/100 gr bodyweight. ${ }^{a}$ Antibody titer against rAChR (meantSEM) 10 weeks after immunization. ${ }^{b}$ The AChR concentration determined in whole carcasses and expressed as pmol AChR/100 gr muscle to compare animals of different bodyweight. ${ }^{C}$ AChR loss is expressed as percentage of the AChR concentration in unmanipulated control rats. "The amount of $A C h R$ complexed with antibody is expressed as the \% of the remaining amount of AChR.

\section{Induction of passive transfer EAMG in young and aged rats}

It was verified whether this resistance to induction of chronic EAMG was also observed when EAMG is induced by passive transfer of anti-AChR antibody. Therefore, passive transfer EAMG was induced in (10-12 wk) and aged (120-130 wk) $\mathrm{BN}$ rats by injection with anti-AChR mAb 35. Administration of $20 \mathrm{pmol} \mathrm{mAb}$ $35 / 100 \mathrm{gr}$ bodyweight to young rats, resulted in clinical manifest EAMG characterized by severe muscular weakness and paralysis at $48 \mathrm{hrs}$ after administration. Affected rats were unable to eat or drink and rapidly losed weight due to dehydration. Young rats showed extreme weight loss compared to control rats treated with normal serum (fig. 1). In contrast, aged rats treated with $20 \mathrm{pmol}$ mAb 35/100 gr clearly showed no signs of EAMG and a marginal weight loss comparable to control rats. Even when aged rats were treated with 60 pmol mAb 35/100 gr mAb 35, no clinical signs were present whereas young rats, treated with the same mAb 35 dose, died within 24 hrs of respiratory failure. Again young rats showed extreme weight loss whereas aged rats were comparable to control young or aged rats (fig. 1). 


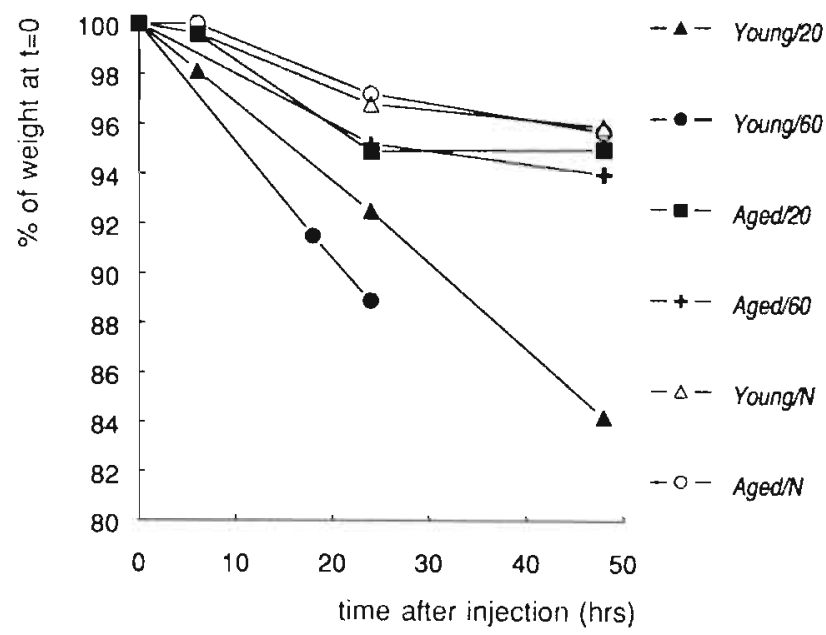

Figure 1: Weight loss as measure for EAMG severity.

The relative weight loss was determined at several points in time after injection of $M A b 35$. Each point represents the mean weight as \% of the weight at the start of the experiment. Young/20: young rats injected with 20 pmol mAb 35/100 gr bodyweight. Young/60: young rats injected with 60 pmol mAb $35 / 100 \mathrm{gr}$. Young/N: young rats treated with normal rat serum. Aged/20: aged rats treated with $20 \mathrm{pmol}$ mAb 35/100 gr. Aged/60: aged rats injected with $60 \mathrm{pmol}$ mAb 35/100 gr. Aged/N: aged rats treated with normal rat serum.

\section{Electromyographic evaluation of neuromuscular transmission}

The decrement of the compound muscle action potential (CMAP) was determined to confirm the observed resistance to the induction of passive transfer EAMG in aged opposed to young rats. The decrement in young and aged rats was determined $48 \mathrm{hrs}$ after administration of mAb 35 . An example of a typical recording from a myasthenic rat is shown in fig. 2A. The decrement in CMAP of aged rats $(n=5)$ injected with $60 \mathrm{pmol} / 100 \mathrm{gr}$ was always within the normal range of less than $10 \%$ (fig. $2 \mathrm{~B}$ ). In contrast, young rats $(n=4)$ injected with $20 \mathrm{pmol} / 100 \mathrm{gr}$ all showed decrement of CMAP ranging from 28 to $75 \%$ (fig. $2 \mathrm{~B}$ ).

\section{Anti-rAChR antibody titers during passive transfer EAMG}

The titer of mAb 35 during the development of passive transfer EAMG was determined at different points in time after intraperitoneal administration of $20 \mathrm{pmol}$ mAb $35 / 100 \mathrm{gr}$ bodyweight. The mean antibody titer against rAChR at 6 and $24 \mathrm{hrs}$ after mAb 35 treatment was not significantly different between young $(n=4)$ and aged rats $(n=3)$. However, at $48 \mathrm{hrs}$ after administration the antibody titer against rAChR declines more rapidly in young rats and is significant lower than in aged rats $(p<0.05)$ (fig. 3). The antibody clearance of $131 \mathrm{l}-\mathrm{lgG}$ in young and aged rats was measured to exclude that differences in antibody clearance determined the induce- 

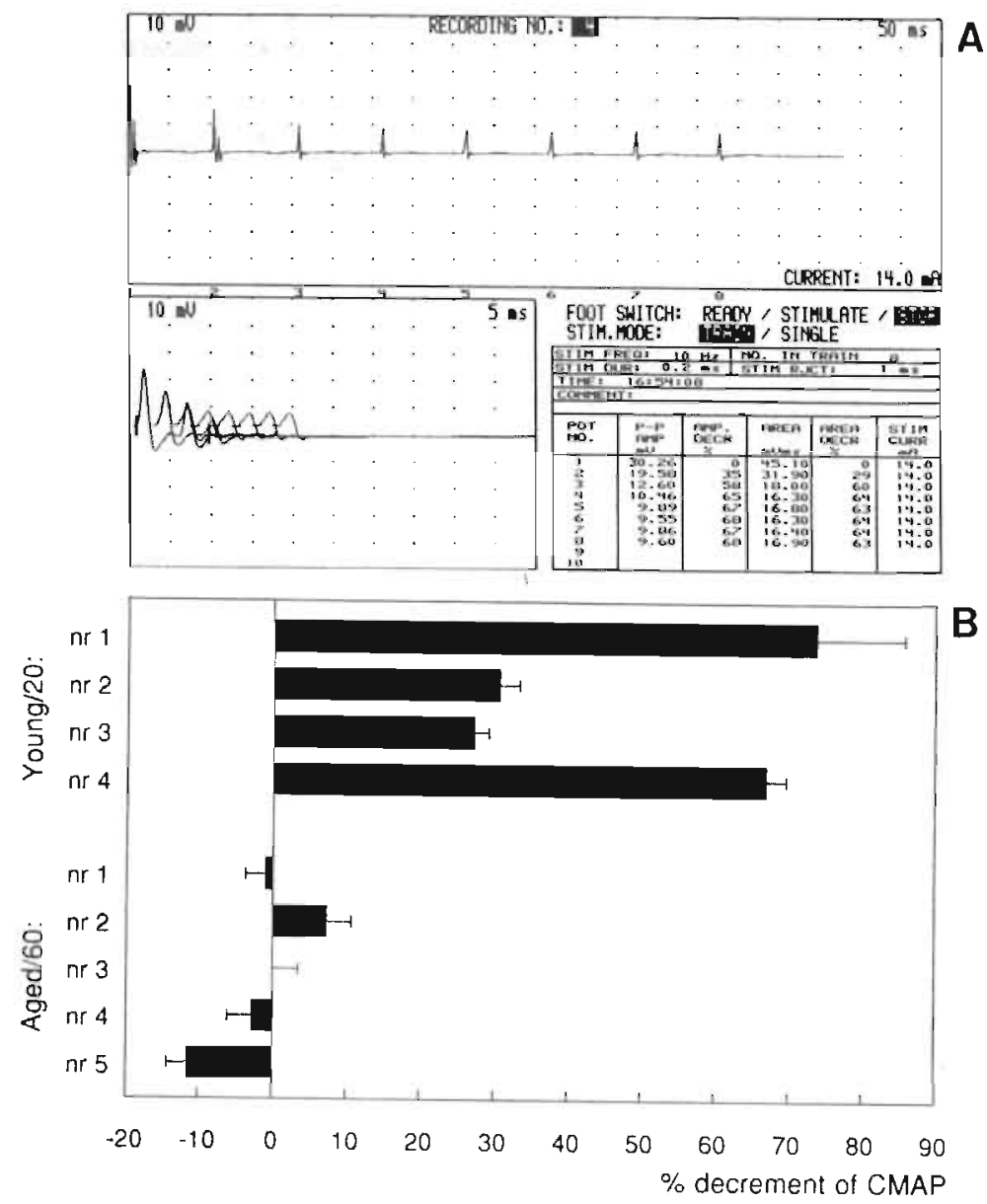

Figure 2: Neuromuscular signal transmission is unaffected in aged rats after passive transfer of mAb 35. The compound muscle action potential (CMAP) at $10 \mathrm{~Hz}$ stimulation was determined 48 hrs after injection of $\mathrm{mAb}$ 35. (A) Example of an electromyogram from the Young/20 group, $48 \mathrm{hrs}$ after passive transfer. (B) The decrement of the CMAP at the fifth stimulus is shown for individual rats. Bars represent the decrement of the CMAP (mean $\pm S D$ ) from three measurements.

ment of passive transfer EAMG in young and aged rats. The mean antibody clearance in young $(n=3)$ and aged $(n=3)$ animals at $5,24,48$ and $72 \mathrm{hrs}$ after administration was comparable (fig. 4).

\section{AChR loss and antibody complexed AChR}

The concentrations of total AChR and antibody complexed AChR were quantitated in young and aged rats 48 hrs after injection of mAb 35 or NRS. The AChR concentrations in the muscles of control young $(n=15)$ and aged $(n=10)$ rats were $55 \pm 11$ and $52 \pm 11 \mathrm{pmol} / 100 \mathrm{gr}$ muscle (mean $\pm \mathrm{SD}$ ) respectively. Young rats injected 


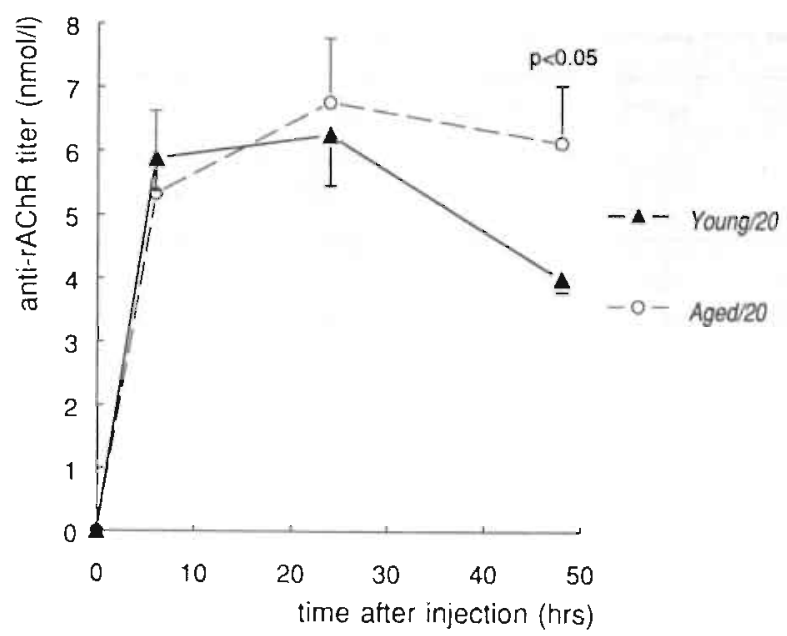

Figure 3: Kinetics of anti-rAChR antibody titer during passive transfer of mAb 35.

The mAb 35 titer against rAChR of Young/20 and Aged/20 rats was determined at 6,24 , and $48 \mathrm{hrs}$ after injection. Values represent the anti-rAChR titer of each group (mean $\pm S D$ ). Statistical differences between mean mAb 35 titers are indicated.

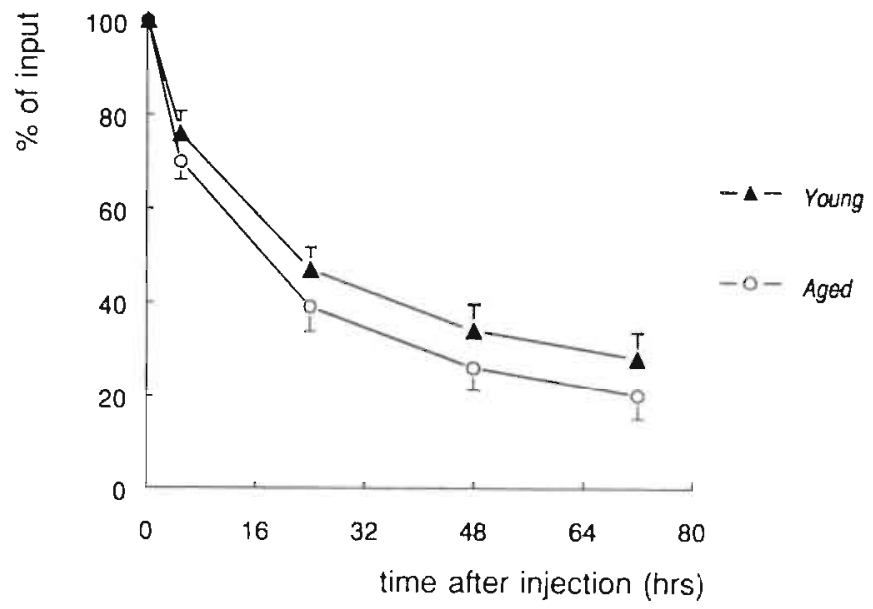

Figure 4: The immunoglobulin clearance in young and aged rats is similar.

The clearance of ${ }^{131} \mathrm{l}-\mathrm{lg} G$ was determined in young and aged $B N$ rats. ${ }^{131} \mathrm{l} / \mathrm{lgG}$ was injected in the lailvein of young $(n=3)$ and aged $(n=3)$ rats and the clearance of ${ }^{131} \mathrm{H} / \mathrm{lg} \mathrm{G}$ was determined $0.25,5,24$. 48 , and $72 \mathrm{hrs}$ after injection. Antibody clearance is expressed as percentage of the input of ${ }^{13 \%} \mathrm{H} / \mathrm{gG}$ injected at the start of the experiment. Values represent mean $\pm S D$.

with 20 pmol mAb $35 / 100$ gr showed $59 \pm 10 \%$ (mean \pm SD) AChR loss whereas

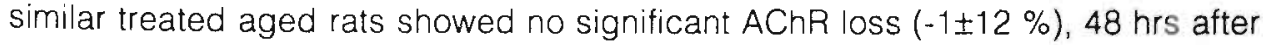
mAb 35 administration (table II). Even aged rats injected with 60 pmol mAb 35/100 gr showed only $10 \pm 1 \%$ AChR loss at $48 \mathrm{hrs}$ after administration. In contrast, young rats injected with the same dose died within $24 \mathrm{hrs}$ after administration at which point in time already $44 \pm 8 \%$ of the receptor was lost (table II). In both young and 
Table II: AChR loss after passive transfer of mAb 35.

\begin{tabular}{|c|c|c|c|c|c|c|}
\hline Rat group & Age & $N$ & $\begin{array}{l}\text { mAb } 35 \text { dose } \\
\text { pmol/100 gr } \\
\text { body weight }\end{array}$ & $\begin{array}{l}{[\mathrm{AChA}]^{\mathrm{a}}} \\
\mathrm{pmol} / 100 \mathrm{gr} \\
\text { muscle }\end{array}$ & $\begin{array}{l}\text { AChR loss } b \\
\%\end{array}$ & $\begin{array}{l}A C h R-A b^{C} \\
\%\end{array}$ \\
\hline young/N & $10 w k$ & 15 & - & $55 \pm 11$ & - & - \\
\hline young/20 & $10 w k$ & 4 & 20 & $23 \pm 5$ & $59 \pm 10$ & $16 \pm 1$ \\
\hline young $/ 60^{d}$ & $10 w k$ & 6 & 60 & $29 \pm 4$ & $44 \pm 8$ & $23 \pm 3$ \\
\hline aged/N & $130 w k$ & 10 & - & $52 \pm 11$ & - & - \\
\hline aged/20 & $125 w k$ & 3 & 20 & $52 \pm 6$ & $-1 \pm 12$ & $11 \pm 1$ \\
\hline aged/60 & $125 w k$ & 5 & 60 & $47 \pm 16$ & $10 \pm 1$ & $22 \pm 2$ \\
\hline
\end{tabular}

The AChR concentration and the fraction of $A C h R$ complexed with mAb 35 was determined 48 hrs after injection of mAb $355^{a}$ The AChR concentration is expressed as pmol AChR/100 gr muscle in order to compare animals of different bodyweight. ${ }^{b}$ AChR loss is expressed as percentage of the AChR concentration in unmanipulated control rats. ${ }^{C}$ The amount of $A C h R$ complexed with antibody is expressed as the \% of the remaining amount of $A C h R .{ }^{d}$ The AChR concentrations in young rats injected with $60 \mathrm{pmol}$ mAb 35/100 gr were determined at the timepoint of death due to paralysis (approximately 22-24 hrs after passive transfer).

aged rats part of the remaining AChR was complexed with mAb 35. In young rats, $16 \pm 1$ and $23 \pm 3 \%$ of the AChRs were complexed with mAb 35 when treated with 20 or $60 \mathrm{pmol} \mathrm{mAb} 35 / 100 \mathrm{gr}$ respectively. In aged rats, $11 \pm 1$ and $22 \pm 2 \%$ of the AChRs were complexed when treated with 20 or $60 \mathrm{pmol}$ mAb $35 / 100 \mathrm{gr}$

\section{Morphology of neuromuscular junction}

The pathogenic effect of mAb 35 on the neuromuscular junction was verified by electron microscopy of muscle biopsies taken from mAb 35 treated rats. The postsynaptic membrane in young rats injected with 20 pmol mAb 35/100 gr was highly simplified or almost completely destroyed. The synaptic cleft was filled with debris and a nerve terminal was separated from the underlying postsynaptic membrane by an infiltrating macrophage (fig. 5A). The neuromuscular junction of similar treated aged rats appeared morphologically intact although some degenerative changes were present. The nerve terminals were closely aposed to the postsynaptic membrane and the junctional folds are well preserved (fig. 5B).

\section{Complement deposition and macrophage infiltration}

The role of complement in the development of passive transfer EAMG in young versus aged rats was assessed by immunohistochemical staining of the $\mathrm{C} 3 \mathrm{com}$ plement component in cryosections of muscle biopsies taken 48 hrs after administration of mAb 35. Depositions of $\mathrm{C} 3$ were found in the muscles of young mAb 

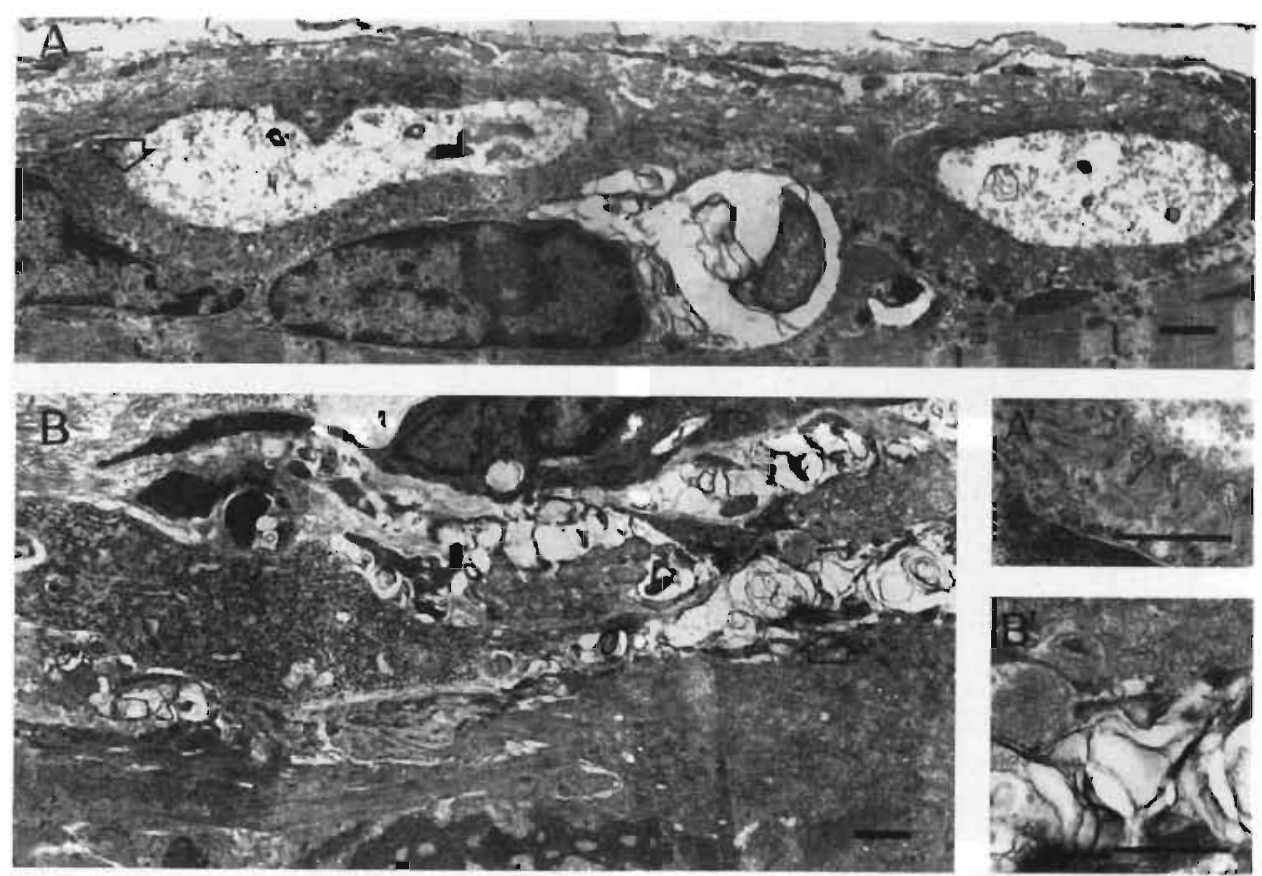

Figure 5: Ultrastructural morphology of endplates after passive transfer of mAb 35.

(A) Two neuromuscular junctions on one muscle fiber of an aged rat 48 hrs after injection with 20 pmol $m A b 35 / 100 \mathrm{gr}$ bodyweight. Degenerative changes are present near a nucleus in between two postsynaptic areas. The postsynaptic junctional folds are well preserved. Open arrow: see insert (A') Detail of junctional folds and synaptic vesicles in the nerve terminal.

(B) Neuromuscular junctions on one muscle fiber of a young rat 48 hrs after injection with $20 \mathrm{pmol}$ mAb $35 / 100 \mathrm{gr}$. The postsynaptic part of the junctions are almost completely destroyed, though some folds can still be discerned. M: infiltrating macrophage. Open arrow: see insert( $\mathrm{B}^{\prime}$ ) This detail shows synaptic vesicles in the preserved nerve terminal and complete degeneration of the postsynaptic part of the junction. Bars represents $1 \mu \mathrm{m}$.

35 treated rats (fig. 6A), which coincided with the localization of AChR at the endplate using $\alpha$-BT-rhodamine (fig. 6B). C3 depositions at the endplate were also demonstrated in EAMG resistant aged rats (fig. 6E and F). No C3 at the endplates could be demonstrated in young (fig. $6 \mathrm{C}$ and $\mathrm{D}$ ) or aged (fig. $6 \mathrm{G}$ and $\mathrm{H}$ ) control rats. Infiltration of activated macrophages in the vicinity of endplates and necrotic muscle fibers was observed in muscle biopsies of young mAb 35 injected rats (fig. $7 \mathrm{~A}$ and $B$ ). In aged rats however, no macrophage infiltration was seen nor necrosis of muscle fibers (fig. 7C and D). Muscle sections from young or aged control rats were free of activated ED 1 positive macrophages (not shown). 

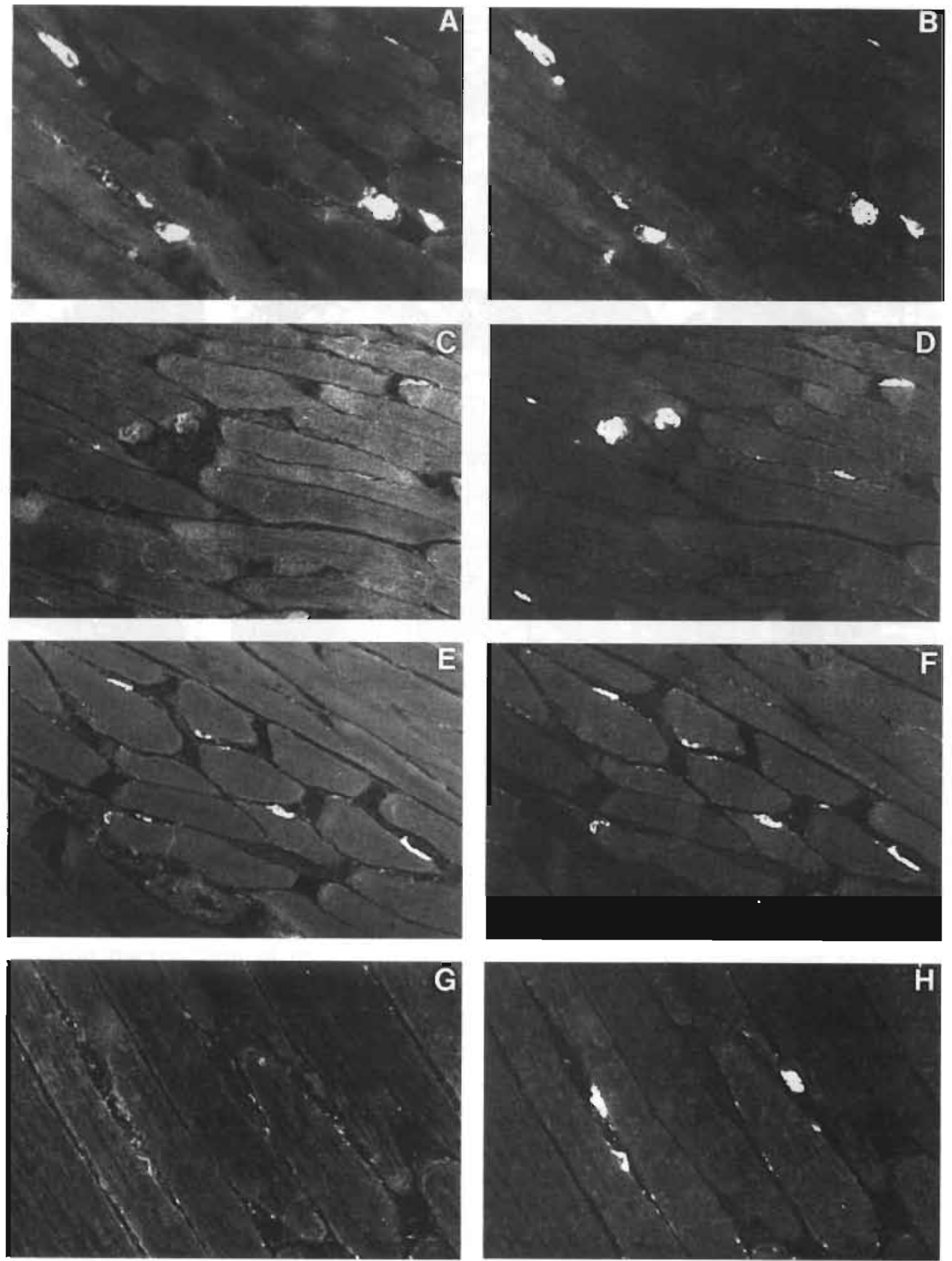

G

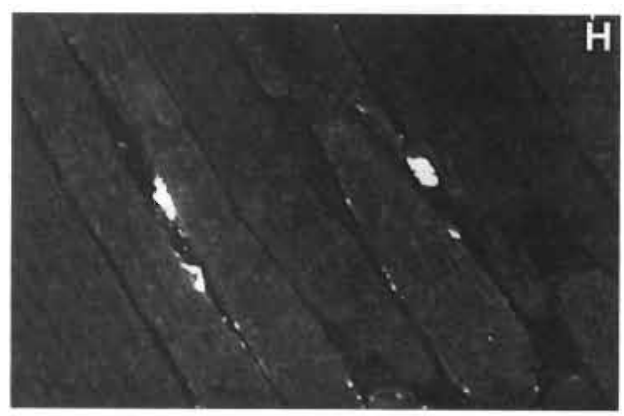

Figure 6: Localization of $\mathrm{C} 3$ at the endplate.

AChRs and 63 deposits were visualized by two color fluoresence in the same muscle section obtained from biopsies taken at 48 hrs after passive transfer. Figures $(A),(C),(E)$, and $(G)$ : muscle sections stained for $C 3$. Figures $(B),(D),(F)$, and $(H)$ : the same muscle sections as in $A, C, E$, and $G$ stained for $A C h R$. Figures $(A)$ and $(B)$ are representative for Young/2O rats. $(C)$ and $(D)$ : Young/N rats, $(E)$ and $(F)$ : Aged/20 rats, (G) and (H): Aged/N rats. 

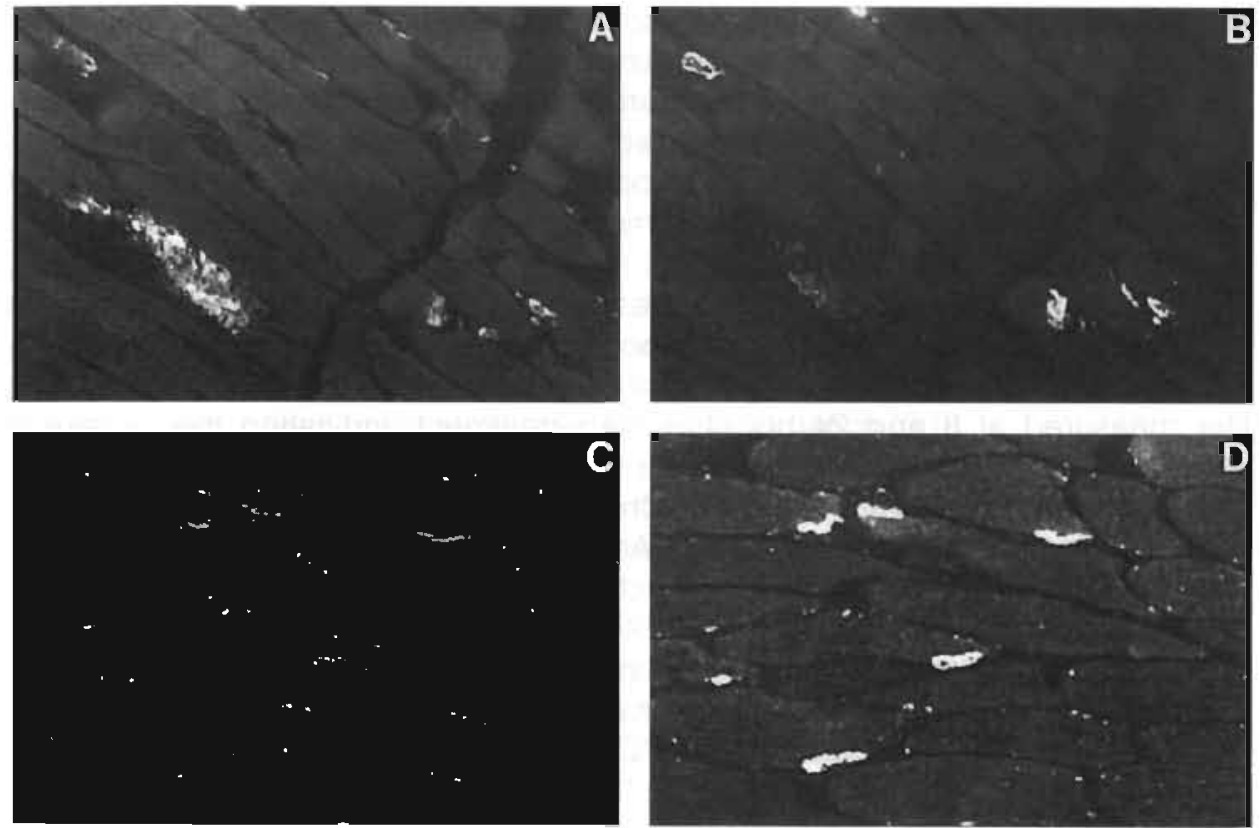

Figure 7: Macrophage infiltration at the endplates after passive transfer of mAb 35.

AChR and infiltrating macrophages were visualized by two color fluoresence in the same muscle section, obtained from biopsies taken at 48 hrs after passive transfer. (A) Muscle sections of young $\mathrm{mAb} 35$ injected rats show massive infitration of macrophages at the motor endplate and in necrotic muscle fibers. (B) The same muscle section stained for AChR with rhodaminated $\alpha-B T$. (C) Macrophages could not be demonstrated at endplates of $m A b$ treated aged rats. $(D)$ The same muscle section stained for AChR.

\section{DISCUSSION}

This present study established the influence of age on the induction of EAMG in the rat. Aged rats were found to be resistant to induction of EAMG by immunization with Torpedo AChR or passive transfer of anti-AChR antibody. The highly reproducible passive transfer EAMG model was used to further investigate this age related resistance to induction of EAMG. Injection of young adult BN rats with monoclonal anti-AChR antibody induced signs of EAMG including severe weight loss, muscle weakness, decrementing electromyographic responses, and ultrastructural alterations of the motor endplate. Similarly injected aged rats remained unaffected and showed no electromyographic or uitrastructural abnormalities at the motor endplate. Aged rats remained resistant even after treatment with a mAb 35 dose exceeding the total AChR content in the muscles. This difference in disease susceptibility between young and aged rats paralleled the magnitude of AChR loss; aged, mAb 35 injected rats showed no loss of AChR whereas young rats showed extensive AChR loss. Depositions of $\mathrm{C} 3$ at the neuromuscular junction could be demonstrated in both young and aged mAb treated rats, however, infiltration of macrophages and segmental necrosis of muscle fibers was only seen in young rats. 
Apparently, no degradation of AChRs occurred in aged rats injected with anti-AChR mAb since no AChR loss or decremental responses could be demonstrated, indicating that neuromuscular signal transmission was unaffected. Several mechanisms could explain the resistance against induction of EAMG in aged rats; differences in antibody uptake or clearance, accessability of the AChR for antibody, activation of complement, or antigenic modulation of AChR could account for age related resistance to EAMG

A prerequisite for comparison of passive transfer EAMG in young and aged rats is a similar anti-rAChR antibody titer in both rat groups after injection of mAb 35. Administration of $\mathrm{mAb} 35$ on weight basis resulted in a similar anti-rAChR antibody titer measured at 6 and $24 \mathrm{hrs}$ after mAb treatment, indicating that uptake of intraperitoneal injected mAb 35 into the circulation was equally efficient in young and aged rats. However, the anti-rAChR titer declined more rapidly in young compared to aged rats at $48 \mathrm{hrs}$ after mAb administration. The observed difference in anti-rAChR titer could not be explained by an age related difference in antibody clearance; a comparable clearance of ${ }^{131} \mathrm{l}-\mathrm{IgG}$ from the circulation was measured in both age groups. The rapid decline in the mAb 35 titer in young compared to aged rats could be the result of an increased $A C h R$ turnover by antigenic modulation $(8,19)$; after internalization of mAb-AChR complexes, AChRs are resynthesized and again capable of binding $\mathrm{mAb}$ resulting in a higher $\mathrm{mAb}$ expenditure.

Complement mediated focal lysis is one of the pathogenic mechanisms leading to AChR loss. In both young and aged animals deposits of C3 were demonstrated in the same distribution as AChRs at the neuromuscular junctions. This indicates that the injected mAb was bound to AChRs in both young and aged rats, and the lack of AChR degradation as seen in aged rats could not be explained by the inaccessibility of the AChR for mAb. Determination of $\mathrm{C} 3$ at the endplates furthermore indicates that complement could be activated in both age groups excluding a complement deficiency in aged rats. Complement activation via the classical pathway (20) is one of the pathogenic mechanisms initiating AChR degradation; complement components were demonstrated at the motor endplate in $M G(21,22)$ and EAMG $(23,24)$. The importance of complement mediated degradation of AChRs in passive transfer EAMG was demonstrated by $\mathrm{C} 3$ depletion with cobravenom factor $(9,25)$, or inhibition of membrane attack complex formation with anti-C6 Fab (26), preventing induction of passive transfer EAMG in rats. Furthermore, induction of EAMG could not be induced in C4 deficient guinea pigs (20) or C5 deficient mice (27).

In addition to $\mathrm{C} 3$ deposits, infiltrating macrophages were found in the vicinity of endplates and in necrotic muscle fibers of young mAb treated rats. This cellular inflammatory reaction was not found in $\mathrm{mAb}$ treated aged rats despite binding of $\mathrm{C} 3$ at the endplates. This suggests that the early complement components $\mathrm{C} 3 \mathrm{a}$ and C5a were not sufficient to attract mononuclear cells and macrophages to the motor endplate of aged rats. Absence of infiltrating macrophages was also demonstrated during inhibition of passive transfer EAMG by treatment with anti-C6 Fab (26), indicating that early complement components were not sufficient to trigger macrophage infiltration. Infiltrating macrophages may therefore be a secondary phenomenon in passive transfer EAMG subsequent to massive tissue destruction by the complement mediated focal lysis in concomitance with antibody mediated in- 
creased AChR turnover. Infiltrating macrophages were not found in chronic EAMG (28). Since induction of chronic EAMG in aged rats also revealed resistance to induction of the disease it was not likely that the absence of infiltrating macrophages was the only factor that determined EAMG resistance.

The resistance to induction of EAMG in aged rats resembled the refractory state observed in rats which recovered from an initial episode of passive transfer EAMG. When these animals were challenged a second time with anti-AChR mAb they remained clinically and electromyographically normal and showed marginal AChR loss (29). This refractory state was characterized by the absence of infiltrating macrophages. It was suggested that AChR concentration or density might be beneath a critical level to initiate further AChR degradation (30).

Beside complement mediated focal lysis, AChR loss is also caused by an increased AChR turnover due to antibody cross-linking. Anti-AChR mAb 35 used to induce passive transfer EAMG is capable of increasing AChR turnover in vitro and protect antigenic modulation of AChR by MG sera (31). The relative contribution of these two pathogenic mechanisms to the development of MG is unknown. These pathogenic mechanisms may not function exclusively, and both mechanisms probably combine to bring about the disease. Complement mediated focal lysis by itself could be insufficient to induce the disease in aged rats and antigenic modulation may be impaired or absent. An increased AChR synthesis rate protected against increased AChR loss by antigenic modulation (32). However, similar AChR half-lives were found in 70 v.s. 844 day old rats (33) and a difference in AChR synthesis between young and aged rats was therefore not likely to explain the resistance to EAMG. The density of AChRs in aged rats may be different from that of young animals, and beneath a critical AChR density at which increased AChR turnover by antibody cross-linking can no longer contribute to AChR degradation. A marked decrease of AChRs per junction has been observed at the endplates of aging rats (33). Moreover, the length of the postsynaptic membrane increases with aging (34), whereas the total AChR concentration in muscle of young and aged rats was found to be comparable. The AChR molecules are $8 \mathrm{~nm}$ in diameter and clustered with very high density at the $\mathrm{NMJ}$; the center to center distance is approximately $10 \mathrm{~nm}$ between two adjacent molecules (35). Cross-linking by antibody is only possible if AChR molecules are in close proximity, at which antibody is able to span the distance between two AChR molecules. The maximum span between the two binding sites of an antibody is approximately $12 \mathrm{~nm}$ (36). Complement activation however, could also be initiated at lower AChR densities. The physical distance between adjacent $\mathrm{Fc}$ parts in order to bind $\mathrm{C} 1 \mathrm{q}$ can be as large as $35 \mathrm{~nm}$ (37).

Taken together, these results suggest that resistance of aged rats against induction of EAMG was related to changes at the NMJ rather than immunological factors. MG is also less frequently observed in humans over 60 years, and the incidence of purely ocular symptoms is relatively higher in patients over the age of 40 (38).

The AChR density and organization may be different in aged rats. A different lipid composition of the postsynaptic membrane may influence AChR organization (39). Furthermore, the membrane rigidity increases with aging (40) and could diminish AChR turnover by antigenic modulation. Age related resistance in the EAMG model can provide more information about the factors that determine the severity of MG. 
Manipulation of AChR density or the lipid composition of the postsynaptic membrane may be of therapeutic interest in MG.

\section{Acknowledgements}

We wish to thank Mieke Henfling and Ruud Aarts for excellent laboratory assistance, and the Beatrix foundation for financial support. 


\section{REFERENCES}

1 Patrick J, Lindstrom J. (1973). Autoimmune response to acetylcholine receptors. Science 180:871-873

2 Toyka KV, Drachman DB, Pestronk A, Kao I. (1975). Myasthenia Gravis: passive transfer from man to mouse. Science 190:397-399

3 Lindstrom JM, Engel AG, Seybold ME, Lennon VA, Lambert EH. (1976). Pathological mechanisms in experimental autoimmune myasthenia gravis. II. Passive transfer of experimental autoimmune myasthenia gravis in rats with anti-acetylcholine receptor antibodies. J. Exp. Med. 144:739-754

4 Lennon VA, Lambert EH. (1980). Myasthenia gravis induced by monoclonal antibodies to acetylcholine receptors. Nature 285:238-240

5 Richman DP, Gomez CM, Berman PW, Burres SA, Fitch FW, Arnason BG. (1980). Monoclonal anti-acetylcholine receptor antibodies can cause experimental myasthenia. Nature 286:738-739

6 Gomez CM, Richman DP. (1983). Monoclonal anti-acetylcholine receptor antibodies with differing capacities to induce experimental autoimmune myasthenia gravis. J. Immunol. 135:234-241

7 Tzartos SJ, Hochschwender S, Vasquez P, Lindstrom J. (1987). Passive transfer of experimental autoimmune myasthenia gravis by monoclonal antibodies to the main immunogenic region of the acetylcholine receptor. J. Neuroimmunol. 15:185-194

8 Kao I, Drachman DB. (1977). Myasthenic immunoglobulin accelerates acetylcholine receptor degradation. Science 196:527-529

9 Lennon VA, Seybold ME, Lindstrom JM, Cochrane C, Ulevitch R. (1978). Role of complement in the pathogenesis of experimental autoimmune myasthenia gravis. J. Exp. Med. 147:973-983

10 Anwyl S, Appel SH, Narashashi T. (1977). Myasthenia gravis serum reduces acetylcholine sensitivity in cultured rat myotubes. Nature 267:262-263

11 Bevan S, Kuhlberg RW, Heinemann SF. (1977). Human myasthenia sera reduce acetylcholine sensitivity of human muscle celis in tissue culture. Nature 267:263-265

12 Lang B, Richardson G, Rees J. Vincent A, Newson-Davis J. (1988). Plasma from myasthenia gravis patients reduces acetylcholine receptor agonist-induced $\mathrm{Na}^{+}$flux into TE671 cell line. J. Neuroimmunol. 19:141-148

13 Lindstrom JM, Einarson BL, Lennon VA, Seybold ME. (1976). Pathological mechanisms in experimental autoimmune myasthenia gravis. I. Immunogenicity of syngeneic muscle acetylcholine receptor and quantative extraction of receptor and antibody-receptor complexes from muscles of rats with experimental autoimmune myasthenia gravis. J. Exp. Med. 144:726-738

14 Verschuuren JJGM, Graus YMF, Theunissen ROM, Yamamoto T, Vincent A, van Breda Vriesman PJC, De Baets MH. (1992). Role of acetylcholine receptor antibody complexes in muscle in experimental autoimmune myasthenia gravis. J. Neuroimmunol. 36:117-125

15 Oh SJ, Eslami N, Hishihira T, Sarala PK, Kuba T, Elmore RS, Nam Sunwoo I, Iro Y. (1982). Electrophysiological and clinical correlation in myasthenia gravis. Ann. Neurol. 12:348-354

16 Pachner AR, Kantor FS. (1982). Nerve stimulation test in murine experimental autoimmune myasthenia gravis. Ann. Neurol. 11:48-52

17 Seybold ME, Lambert EH, Lennon VA, Lindstrom JM. (1976). Experimental autoimmune myasthenia gravis: clinical, neurophysiological, and pharmacological aspects. Ann. N.Y. Acad. Sci. 274:275-282

18 Dijkstra CD, Döpp EA, Joling P, Kraal G. (1985). The heterogeneity of mononuclear phagocytes in lymphoid organs: distinct macrophage subpopulations in the rat recognized by monoclonal antibodies ED1, ED 2 and ED 3. Immunol. 54:589-599 
19 Drachman DB, Angus CW, Adams RN, Michelson JD, Hoffman BM. (1978). Myasthenic antibodies cross-link acetylcholine receptors to accelerate degradation. N. Eng. J. Med. 298:1116-1122

20 Lennon VA, Lambert EH. (1981). Monoclonal autoantibodies to acetylcholine receptors: evidence for a dominant idiotype and requirement of complement for pathogenicity. Ann. N.Y. Acad. Sci. 377:77-96

21 Engel AG, Lambert EH, Howard FM. (1977). Immune complexes (lgG and C3) at the motor endplate in myasthenia gravis. Ultrastructural and light microscopic localization and electrophysiologic correlations. Mayo Clin. Proc. 52:267-280

22 Sahashi K, Engel AG, Lambert EH, Howard FM. (1980). Ultrastructural localization of the terminal and lytic ninth complement component (C9) at the motor endplate in myasthenia gravis. J. Neuropathol. Exp. Neurol. 39:160-172

23 Sahashi K, Engel AG, Lindstrom JM, Lambert EH, Lennon VA. (1978). Ultrastructural localization of immune complexes (IgG and C3) at the endplate in experimental autoimmune myasthenia gravis. J. Neuropathol. Exp. Neurol. 37:213-233

24 Engel AG, Sakakibara H, Sahashi K, Lindstrom JM, Lambert EH, Lennon VA. (1979). Passively transferred experimental autoimmune myasthenia gravis. Sequential and quantitative study of the motor endplate fine structure and uitrastructural localization of immune complexes (IgG and C3), and of the acetylcholine receptor. Neurology 29:179188

25 Toyka KV, Drachman DB, Griffin DE, Pestronk A, Winkelstein JA, Fishbeck KH, Kao I. (1977). Study of humoral immune mechanisms by passive transfer to mice. N. Eng. J. Med. 296:125-131

26 Biesecker G, Gomez CM. (1989). Inhibition of acute passive transfer experimental autoimmune myasthenia gravis with Fab antibody to complement C6. J. Immunol. 142:2654-2659

27 Christados P. (1988). C5 influences the development of murine myasthenia gravis. J. Immunol. 140:2589-2592

28 Lennon VA, Lindstrom JM, Seybold ME. (1976). Experimental autoimmune myasthenia gravis: cellular and humoral immune responses. Ann. N.Y. Acad. Sci. 274:283-299

29 Corey AL, Richman DP, Shuman CA, Gomez CM, Arnason BGW. (1985). Use of monoclonal anti-acetylcholine receptor antibodies to investigate the macrophage inflammation of acute experimental myasthenia gravis. Neurology 35:1455-1460

30 Corey AL, Richman DP, Agius MA, Wollmann RL. (1987). Refractoriness to a second episode of experimental myasthenia gravis. Correlation with AChR concentration and morphological appearance of the postsynaptic membrane. J. Immunol. 138:3269-3275

31 Tzartos SJ, Sophianos D, Efthimiadis A. (1985). Role of the main immunogenic region of acetylcholine receptor in myasthenia gravis. An Fab monoclonal antibody protects against antigenic modulation by human sera. J. Immunol. 134:2343-2349

32 De Baets MH, Verschuuren JJGM, Daha MR, van Breda Vriesman PJC. (1988). Effects of the rate of acetylcholine receptor synthesis on the severity of experimental autoimmune myasthenia gravis. Immunol. Res. 7:200-211

33 Courtney J, Steinbach JH. (1981). Age changes in neuromuscular junction morphology and acetylcholine receptor distribution on rat skeletal muscle fibres. J. Physiol. 320:435447

34 Wokke JHJ, Jennekens FGI, Van Oord CJM, Veldman H, Smit LME, Leppink GJ. (1990). Morphological evidence of remodeling in the aging human endplate. J. Neurol. Sci. 95:291-310

35 Cartaud J, Benedetti L, Sobel A, Changeux JP. (1978). A morphological study of the cholinergic receptor protein from Torpedo marmorata in its membrane environment and its detergent extracted form. J. Cell. Sci. 29:313-337 
36 Valentine RC, Green NM. (1967). Electron microscopy of an antibody-hapten complex. J. Mol. Biol. 27:615-617

37 Knobel HR, Villiger W, Isliker H. (1975). Chemical analysis and electronmicroscopy studies of human $\mathrm{C} 1 \mathrm{q}$ prepared by different methods. Eur. J. Immunol. 5:78-82

38 Oosterhuis H. (1981). Myasthenia gravis. A survey. Clin. Neurol. Neurosurg. 83: 105-135

39 Scher MG, Bloch RJ. (1991). The lipid bilayer of acetylcholine receptor clusters of cultured rat myotubes is organized into morphologically distinct domains. Exp. Cell. Res. 195:79-91

40 Shinitzky M, Barenholz Y. (1978) Fluidity parameters of lipid regions determined by fluorescence polarization. Biochem. Biophys. Acta. 515:367-394 
Chapter 3

The genetic basis of antibody diversity 


\section{The genetic basis of antibody diversity}

\section{Introduction}

An important feature of the immune system is its ability to recognize and interact with any foreign antigen in a very specific fashion. This potential repertoire may include specificities that interact with self components that emerge in autoimmune disease. Autoimmune disease may arise from loss of suppression of pathogenic specificities within the normal repertoire, or result from abnormalities in the generation of the $T$ and $B$ cell receptor repertoire. The autoimmune disease myasthenia gravis is mediated by pathogenic antibodies against the acetylcholine receptor. However, what initiates this humoral autoimmune response is yet unknown. Insight into the generation of these antibodies could provide important aetiological information about the disease.

It was demonstrated in a previous study that various anti-AChR mAbs share antigenic determinants on their variable region (cross-reactive idiotopes). The cross-reactive idiotopes were expressed on both rat and mouse anti-AChR antibodies (1). Cross-reactive idiotopes can have a role in regulation of the immune response by interaction with anti-idiotypes; administration of a low dose of polyclonal affinity purified anti-idiotype 65 antibodies to neonatal rats resulted in an increased antibody response to both Torpedo and rat AChR after immunization with AChR at adult age (104).

Expression of a cross-reactive idiotype (CRI) by anti-AChR antibodies suggested that these antibodies may be structurally related and could be encoded by related genetic elements. If anti-AChR antibodies consist of a group of related antibodies it could be possible that anti-AChR antibodies arise from one or a few clones due to clonal expansion. To address this question we investigated the diversity of genetic elements that are used to encode the heavy chain region of anti-AChR mAbs.

To study the genetic diversity of anti-AChR antibodies it is useful to have insight in the structural elements that determine antibody diversity. This chapter gives an outline of the genetic elements encoding the variable region of antibodies which are very well characterized in the mouse. Furthermore, an overview of the genetic diversity of (auto)antibodies from normal and autoimmune mice strains is given, and the structural basis for expression of a CRI will be discussed. 


\section{Immunoglobulin structure}

Immunoglobulin ( $\mathrm{lg})$ molecules are composed of two identical heavy chains and two light chains with a molecular weight of 50000 and 25000 dalton respectively (2, $3)$. Each chain consists of a variable part $\left(V_{H}\right.$ and $\left.V_{L}\right)$ involved in antigen recognition, and a constant part $\left(\mathrm{C}_{\mathrm{H}}\right.$ and $\left.\mathrm{C}_{\mathrm{L}}\right)$. The constant part of the heavy chain $\left(\mathrm{C}_{\mathrm{H}}\right)$ defines the isotype of the immunoglobulin molecule and mediates biological functions including complement fixation and activation, and binding to phagocytic cells. In mice, eight isotypes ( $\lg M, \lg D \lg G 3, \lg G 1, \lg G 2 b, \lg G 2 a, \lg E$, and $\lg A$ ) have been identified all having different biological functions (4).

The variable region of $\lg$ heavy $\left(V_{H}\right)$ and light $\left(V_{L}\right)$ chains consist of a framework of relatively conserved amino acids interrupted by three highly variable regions. The three hypervariable- or complementary determining regions (CDR) of each heavy and light chain together form the antigen binding site $(5,6)$.

\section{Generation of antibody diversity}

The Ig molecule is encoded by three unlinked clusters of genes: the light chain can be encoded by two separate gene clusters whereas the heavy chain is encoded by a single cluster of heavy chain genes. In the mouse, the $\lambda$ and $\kappa$ genes are localized on chromosomes 16 and 6 respectively, and the heavy chain genes on chromosome $12(10,11,12)$. The majority of the light chains in the mouse is encoded by $\mathrm{k}$ light chain genes and only about $5 \%$ by $\lambda$ light chain genes. The $\kappa$ light chain can be encoded by approximately 300 variable, 4 joining and 1 constant gene segment ( 7 , 8), whereas the $\lambda$ light chain can be encoded by 2 variable, 4 joining and 4 constant gene segments (9).

The gene that encodes the variable part of the heavy chain is assembled from three separate germline gene segments; a variable $\left(V_{H}\right)$, diversity $(D)$, and a joining $\left(J_{H}\right)$ gene segment (13). The variable part of the light chain gene is encoded by a variable $\left(V_{L}\right)$, and joining $\left(J_{H}\right)$ gene segment (fig. 1). Two of the CDRs are encoded by the $V_{H}$ or $V_{L}$ genes and the third CDR is encoded by the $V-D-J$ junctional region in heavy chains and the $V-J$ junctional region in light chains.

The variable region of the heavy chain can be coded by 200-1000 $V_{H}, 13 \mathrm{D}$, and 4 $J_{H}$ gene segments (14). The diversity of antibodies is generated at several levels:

I Multiple distinct germline gene segments encode unique $V, D$ or $\mathrm{J}$ amino acid sequences

II Different $V_{H}, D$ and $J_{H}$ or $V_{L}$ and $J L$ genes can recombine to form many different complete variable region genes

II! Imprecise joining of gene segments resulting in deletion or de novo addition of nucleotides generating additional diversity in CDR 3

IV Differential combining of complete heavy-and light chains

$\checkmark$ Somatic mutation can modify the coding capacity of complete assembled variable region genes 


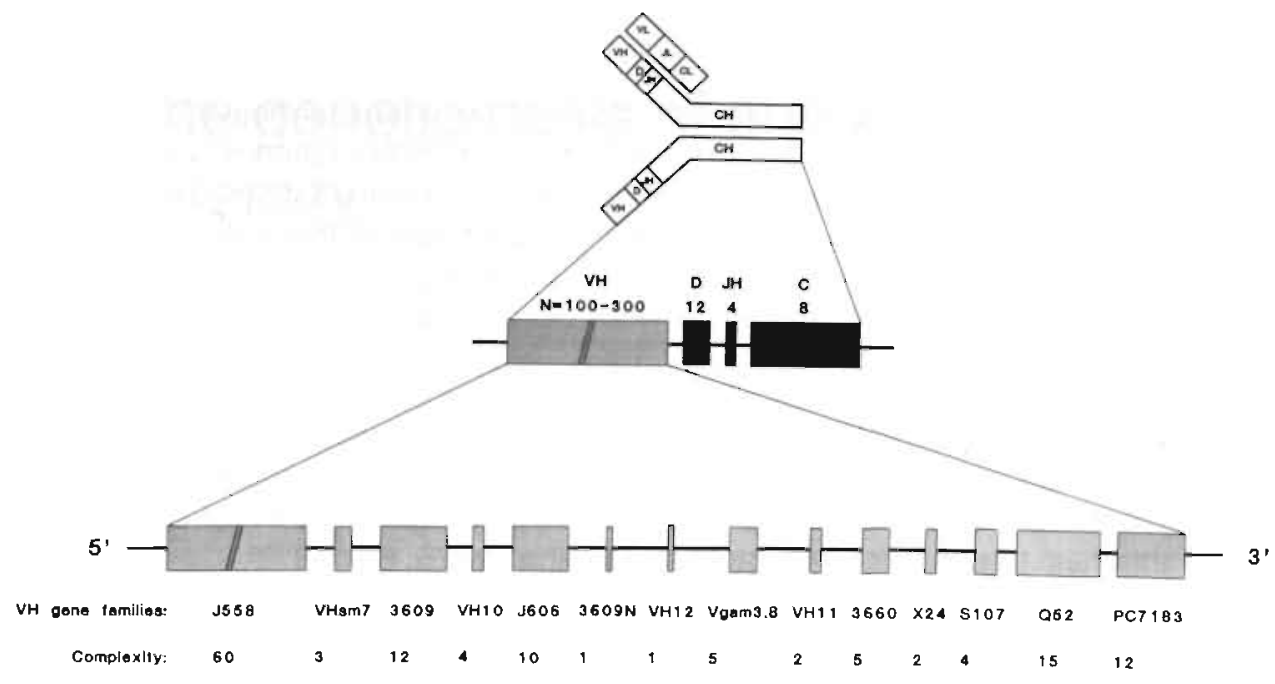

Figure 1: Overview of the $\mathrm{VH}$ gene families

The immunoglobulin heavy chain is composed of 4 different elements encoding the variable $\left(V_{H}\right)$, diversity $(D)$, joining $\left(J_{H}\right)$ and constant $(C)$ region. The $V_{H}$ genes are currently grouped in $14 V_{H}$ gene families that comprise $V_{H}$ genes with a sequence homology of $80 \%$ or more. The sequence homology between members of different families is less than $70 \%$. The presumed localization of the $V_{H}$ gene families relative to the diversity region is shown. The complexity of a $V_{H}$ gene family represents the estimated number of $V_{H}$ genes belonging to that family

The combined effect of these mechanisms is estimated to generate $10^{9}$ different antigen specificities.

\section{The mouse $\lg V_{H}$ gene locus}

The 200-1000 $V_{H}$ genes are the largest group of gene fragments that contribute to the formation of the heavy chain variable region and are responsible for a significant portion of the potential antibody repertoire. Murine heavy chain $V_{H}$ gene segments were originally divided into three major subgroups on the basis of protein sequences (15). However, when $V_{H}$ genes were compared on nucleotide sequence homology, they could be divided in 7 different $V_{H}$ gene families $(16,17)$. Now 14 different $V_{H}$ gene families are discriminated (17-22). $V_{H}$ gene segments showing a mutual homology of $80 \%$ or more are considered to belong to the same $V_{H}$ gene family while $V_{H}$ gene segments that show less than $70 \%$ sequence homology are considered to be from different families $(16,17)$. The size or complexity of a $V_{H}$ gene family was estimated by counting the number of germ-line DNA fragments on a Southern blot hybridized with a probe representative for a $V_{H}$ gene family. This approach was based on the observation that individual murine $V_{H}$ gene segments are located with 10 to $20 \mathrm{~kb}$ intervals on the chromosomal DNA $(23,24)$. Therefore, when genomic DNA is cut with restriction enzyme Eco RI generating fragments ranging from 1 to $20 \mathrm{~kb}$, each fragment should contain a single $V_{H}$ gene. The total 
number of hybridizing fragments gives a minimum estimate of the number of sequences that are more than $80 \%$ homologous to the $V_{H}$ probe used $(17,24)$. Using this approach the total number of $V_{H}$ gene sequences is estimated to be 200 (17), but may be underestimated and be as large as 1000 or more $(25,26)$. This underestimation may be due to the fact that $V_{H}$ gene sequences are more closely spaced resulting in multiple $V_{H}$ sequences on one restriction fragment and the existence of restriction fragments of equal size that co-migrate during gel electroforesis and can not be discriminated as separate bands (26, 27-29). However, the number of unique $V_{H}$ gene sequences encoding functional and disctinct antibody specificities is probably less than the total number of hybridizing $V_{H}$ gene segments. The total number of hybridizing $V_{H}$ gene segments contains a considerable number of $V_{H}$ pseudogenes incapable of coding a functional $V_{H}$ gene product and the existence of multiple copies of identical $V_{H}$ gene sequences $(25,28,29-31)$. The size of the total available $V_{H}$ gene repertoire was determined in normal splenic hybridomas or B-cell colonies and suggested to be less than 300 (32) and the frequency of occurence of $V_{H}$ gene segments from a particular family in normal $B$ cells is in good agreement with the complexity of that family determined by "band counting" in a Southern blot $(31,33,34)$.

Murine $V_{H}$ gene families are generally grouped as clusters of related $V_{H}$ genes (23, $24,26,35,36)$. The $V_{H}$ gene families have been mapped relative to the constant region genes using deletion mapping. Deletion mapping is based on the fact that rearrangement of $a V_{H}$ gene to the $D$ and $J_{H}$ genes results in the deletion of DNA originally separating the $V_{H}$ gene from the $D-J_{H}-C_{H}$ region (37). In $B$ cells that have rearranged $V_{H}$ genes on both chromosomes, all $V_{H}$ gene segments lying downstream (or 3') from the used $V_{H}$ gene segments are deleted and can no longer be detected in a Southern blot. Using this technique it was possible to map all $V_{H}$ gene families relative to each other $(21,22,38-43)$. The relative organization and complexity of each $V_{H}$ gene family is depicted in figure 1. In general each $V_{H}$ gene family is clustered although the 3660 , Vgam3.8 and $\mathrm{S} 107 \mathrm{~V}_{\mathrm{H}}$ gene families are dispersed into two or three subregions. The $J 558$ and $3609 V_{H}$ gene families are partiatly interspersed whereas members of the Q52 and PC7183 $V_{H}$ gene families are completely interspersed at the $3^{\prime}$ end of the $\operatorname{IgV}_{H}$ locus $(30,40,41)$.

\section{$V_{H}$ gene utilization by the normal $B$ cell repertoire}

Selection of $V_{H}$ genes from the different $V_{H}$ gene families was found to be highly restricted early in $\mathrm{B}$ cell development and eventually becomes random during maturation of the $B$ cell repertoire. B cells isolated from mouse fetal liver and neonatal spleen early in ontogeny preferentially rearrange $V_{H}$ genes from the most D-proximal $V_{H}$ gene family $P C 7183(35,36,44-46)$. Within $5-7$ days after birth the $V_{H}$ gene repertoire is randomized such that expression of $V_{H}$ genes correlates with the size (or complexity) of the $V_{H}$ gene family from which the $V_{H}$ gene is derived $(45,46)$. Individual $V_{H}$ gene segments expressed in LPS stimulated $(33,34,47$, 48-50) or unstimulated $(50,51) \mathrm{B}$ cells were found to be distributed stochastically over the different $V_{H}$ gene families which suggests that all individual $V_{H}$ genes are represented at equal frequencies in the available and actual aduit $B$ cell repertoires 
respectively. In contrast. The $V_{\kappa}$ gene family expression in LPS stimulated $B$ lymphocytes was not proportional to the complexity of the $V_{\kappa}$ gene families (52).

The underlying mechanism of this "normalization" of $V_{H}$ gene family utilization during $B$ cell development is unknown, but several factors including intrinsic genetical properties governing rearrangement and transcription of $V_{H}$ genes (53), interactions with accessory cells (54) or stimulation by exogenous antigens (55) contribute to this process.

\section{$\mathrm{V}_{\mathrm{H}}$ gene utilization by autoantibodies}

A key question in the understanding of antibody mediated autoimmune disease is whether autoantibodies are a separate entity within the whole B cell population. Autoreactive $B$ cells may be normal constituents of the immune system which remain unstimulated or suppressed unider normal physiologic conditions. Alternatively, pathogenic autoantibodies may arise from abnormalities in the generation of the $\mathrm{B}$ cell repertoire and anti-self antibodies may be encoded by unique $\mathrm{V}_{H}$ gene segments. It was suggested that murine autoantibodies of various specificities are encoded by a restricted number of $V_{H}$ genes in particular $V_{H}$ genes from the $V_{H}$ gene families Q52 and PC7 183 which are most proximal to the diversity region genes $(56,57)$. Moreover, $B$ cell hybridomas selected for expression of $V_{H}$ genes from the PC7183 family produce autoantibodies at a high frequency $(58)$. $V_{H}$ genes

Table 1: Overview of $V_{H}$ gene family utilization of autoantibodies from autoimmune prone mice.

\begin{tabular}{|c|c|c|c|c|c|c|c|c|c|c|c|c|c|}
\hline \multirow[t]{2}{*}{ mouse strain } & \multirow[t]{2}{*}{ stimulus ${ }^{a}$} & \multirow[t]{2}{*}{ mAb specificity $b$} & \multicolumn{9}{|c|}{$V_{H}$ gene family utilization ${ }^{c}$} & \multirow[t]{2}{*}{$\mathrm{Nr}{ }^{\mathrm{d}}$} & \multirow[t]{2}{*}{ Ref. } \\
\hline & & & $J 558$ & 3609 & $J 606$ & Vgam3.8 & 3660 & $\times 24$ & $\$ 107$ & Q52 & 7183 & & \\
\hline MRL $/ \mathrm{pr} / \mathrm{pr}$ & - & RF & 0 & 0 & 0 & 0 & 9 & 0 & 0 & 0 & 0 & 9 & 67 \\
\hline MRL $\mid \mathrm{pr} / \mathrm{lpr}$ & - & RF & 32 & 0 & 0 & 0 & 1 & 0 & 0 & 0 & 0 & 35 & 68 \\
\hline MRL /pr/pr & - & $\mathrm{RF}$ & 3 & 0 & 0 & 0 & 0 & 0 & 0 & 0 & 0 & 3 & 70 \\
\hline MRL lpr/lpr & - & DNA & 7 & 0 & 0 & 0 & 0 & 0 & 1 & 2 & 3 & 13 & 56 \\
\hline $\begin{array}{l}\text { MRL lpr/pr } \\
\text { NZB, CBA, 129SV }\end{array}$ & - & $\begin{array}{l}\text { RF, DNA, Sm, } \\
\text { BrMRBC }\end{array}$ & 7 & 0 & 0 & 0 & 0 & 0 & 1 & 1 & 10 & 19 & 57 \\
\hline $\mathrm{C} 57 \mathrm{bV} / 6 \mathrm{me}^{\mathrm{v} / \mathrm{me}^{\mathrm{v}}}$ & LPS & Several auto-Ag & 8 & 0 & 0 & 0 & 1 & 0 & 0 & 2 & 0 & 12 & 71 \\
\hline $\mathrm{C} 57 \mathrm{~b} / 6 \mathrm{me} / \mathrm{me}^{V}$ & - & Several auto- $\mathrm{Ag}$ & 5 & 0 & 2 & 0 & 0 & 3 & 3 & 0 & 2 & 17 & 72 \\
\hline NZB & - & mouse $\mathrm{RBC}$ & 6 & 1 & 1 & 0 & 0 & 0 & 0 & 0 & 0 & 8 & 73 \\
\hline NZBxNZW & - & DNA & 15 & 1 & 0 & 0 & 0 & 0 & 1 & 1 & 3 & 23 & 74 \\
\hline SM/J & LPS & Thymocytes & 7 & 4 & 0 & 1 & 0 & 0 & 0 & 2 & 0 & 14 & 74 \\
\hline \multirow[t]{3}{*}{ MRL |pr/lpr } & - & Several auto-Ag & 70 & 0 & 3 & 0 & 1 & 0 & 5 & 15 & 8 & 119 & 103 \\
\hline & & lotal & 160 & 6 & 6 & 1 & 12 & 3 & 11 & 23 & 26 & 272 & \\
\hline & & $\%$ & 59 & 2 & 2 & 0 & 4 & 1 & 4 & 8 & 10 & - & \\
\hline
\end{tabular}

Spontaneous or lipopolysaccharide (LPS) stimulated autoreactive hybridomas were isolated from autoimmune prone mice and tesled for $V_{H}$ gene family utilization by Northern blot- or DNA sequenceanalysis. The number of hybridomas positive for each $V_{H}$ gene family is shown. ${ }^{a} B$ cells were either unstimulated (-), or LPS stimulated. 'Autoantigen specificity: RF; rheumatoid factor, Sm; Smith antigen, BrMRBC; Bromelain treated mouse red blood cells. "Nine of the 14 known $V_{H}$ gene families arranged in presumed chromosomal order relative to the D-region. 'Total number of hybridomas tested for $V_{H}$ gene family utilization. 


\section{Table Il: Overview of $V_{H}$ gene family utilization of autoantibodies from normal non-autoimmune mice}

\begin{tabular}{llll}
\hline mouse strain & stimulus $^{a}$ mAb specificity & $V_{H}$ gene family utilization $^{c}$ & Nr. ${ }^{d}$
\end{tabular}

J558 3609 J606 Vgam3.8 $3660 \times 24 \quad 5107 \quad 052 \quad 7183$

\begin{tabular}{|c|c|c|c|c|c|c|c|c|c|c|c|c|c|}
\hline $\begin{array}{l}\text { Balb/c, CBA } \\
\text { BDA } 1\end{array}$ & $\rightarrow$ & Several auto- $\mathrm{Ag}$ & 10 & 0 & 0 & 0 & 0 & 0 & 0 & 4 & 10 & 24 & 57 \\
\hline \multirow[t]{2}{*}{ Balb/c } & insulin & insulin & 2 & 0 & 0 & 2 & 0 & 0 & 0 & 0 & 0 & 43 & 79 \\
\hline & - & tissue antigens & 7 & 2 & 0 & 0 & 0 & 0 & 0 & 3 & 1 & 13 & 76 \\
\hline C57b/6xDBA/2 & $\begin{array}{l}\mathrm{DBA} / 2 \\
\mathrm{~T} \text { cells }\end{array}$ & kidney & 3 & 0 & 0 & 0 & 0 & 0 & 0 & 0 & 1 & 4 & 80 \\
\hline C57bV 6 & LPS & several auto-Ag & 2 & 0 & 0 & 2 & 0 & 0 & 0 & 0 & 0 & 8 & 71 \\
\hline DBA1, B10p & collagen & collagen II & 6 & 0 & 0 & 0 & 2 & 1 & 0 & 1 & 2 & 13 & 81 \\
\hline CBA/J & $\mathrm{Tg}$ & thyroglobulin & 6 & 0 & 0 & 0 & 0 & 0 & 0 & 2 & 1 & 10 & 82 \\
\hline$?$ & LPS, ? & RF & 6 & 0 & 1 & 0 & 0 & 0 & 0 & 0 & 1 & 8 & 77 \\
\hline $\mathrm{BDF} / 1$ & $\begin{array}{l}\mathrm{DBA} / 2 \\
\text { T cells }\end{array}$ & tissue antigens & 47 & 0 & 1 & 0 & 1 & 2 & 0 & 3 & 1 & 56 & 83 \\
\hline \multirow[t]{3}{*}{ AJ } & $\begin{array}{l}\text { LPS + } \\
\text { dextran }\end{array}$ & several auto-Ag & 16 & 0 & 2 & 0 & 1 & 0 & 0 & 5 & 2 & 26 & 78 \\
\hline & & total & 105 & 2 & 4 & 4 & 4 & 3 & 0 & 18 & 19 & 166 & \\
\hline & & $\%$ & 63 & 1 & 2 & 2 & 2 & 2 & 0 & 11 & 11 & - & \\
\hline
\end{tabular}

Autoreactive hybridomas from non-autoimmune mice were tested for $V_{H}$ gene family utilization by Northern blot-or DNA sequence-analysis. ${ }^{a} B$ cells were either unstimulated $(-)$, polyclonally stimulated by lipopolysaccharide, or induced by active immunization. ${ }^{\circ}$ Autoantigen specificity: Tg; thyroglobulin, RF; rheumatoid factor. "Nine of the 14 known $V_{H}$ gene families arranged in presumed chromosomal order relative to the $D$-region. "Total number of hybridomas tested for $V_{H}$ gene family utilization

from these D-region proximal $V_{H}$ gene families are predominantly rearranged early in $\mathrm{B}$ cell development $(35,36,59)$. During this stage in the ontogeny, B cells are mostly multireactive and frequently display specificity for several autoantigens (60). In addition, ly-1+ $\left(\mathrm{CD} 5^{+}\right)$B cells which phenotypically resemble early B cells frequently have autoantigen specificity $(61,62)$. These results suggested that autoantibodies are encoded by a limited set of $V_{H}$ genes which may be related to a defective control of $V_{H}$ gene expression (63). Autoantibody producing $B$ cells may escape from this primary $B$ cell pool during shaping of the adult B cell repertoire. Since this observation many investigators have addressed the question whether autoantibodies show a biased $V_{H}$ gene usage. To determine a possible bias in $V_{H}$ gene usage from different $V_{H}$ gene families, hybridomas with several autoantigen specificities were isolated from either autoimmune prone or normal mice.

\section{$V_{H}$ gene family utilization in autoimmune prone mice:}

Autoimmune prone mice strains provide spontaneously arising models for autoimmune diseases like Coombs hemolytic anaemia (NZB), Systemic lupus erythrematosus (NZBXNZW), rheumatoid arthritis (MRL Ipr/lpr). Furthermore, viable motheaten mice show severe autoimmune syndromes and nearly all of their $B$ cells are of the Ly-1 lineage (64). The $V_{H}$ gene family usage of autoreactive hybridomas from autoimmune prone animals are summarized in table I. Several studies reported a 
D-proximal bias in $V_{H}$ gene family utilization of autoantibodies from autoimmune prone mice $(56,57,65,66)$. Furthermore, a preferential usage of the $3660(67)$ or the $J 558(68)$ family was demonstrated for rheumatoid factors isolated from MRL $\mathrm{lpr} / \mathrm{lpr}$ mice. However, it is clear that all other $V_{H}$ genes from all tested $V_{H}$ gene families can encode autoantibodies. Moreover, when the results of all these studies are compiled, the $V_{H}$ gene family utilization follows a stochastic distribution over the $V_{H}$ gene families and no bias or preferential use of certain $V_{H}$ gene families is observed (fig. 2).

Taken together these results indicate that autoreactive B cells in these autoimmune prone animals are not likely the result of an impaired normalization of the initial $D$-proximal bias in $V_{H}$ gene family utilization early in ontogeny. This notion is supported by studies that determine $V_{H}$ gene family utilization among unstimulated $B$ cells from autoimmune mice by direct quantative in situ hybridization. These studies in MRL Ipr/lpr $(51,69)$ and "viable motheaten" mice (47) showed no $D$-proximal bias in $V_{H}$ gene family utilization.

\section{$V_{H}$ gene family utilization in autoantibodies from normal mice:}

Autoreactive hybridomas obtained from normal non-autoimmune mice, either natural occuring (75), experimentally induced by polyclonal stimulation $(71,77,78)$, or active immunization $(57,79-83)$, were found to be encoded by $V_{H}$ genes from most $V_{H}$ gene families (table II). Monestier et al reported a D-proximal bias in $V_{H}$ gene family usage among autoantibodies derived from different non-autoimmune mice strains, with various autoantigen specificity (57). However, when results from individual studies are compiled, the $V_{H}$ gene utilization is distributed stochastically over the $V_{H}$ gene families (fig. 2). These results indicate that a wide variety of $V_{H}$ genes are found in autoantibodies. $V_{H}$ genes encoding autoantibody specificities are probably not predisposed to a certain $V_{H}$ gene family (44).

\section{The structural basis for cross-reactive idiotypes}

Idiotypes are antigenic markers of the variable region of immunoglobulins $(\mathrm{lg})$ that were originally detected by antisera (anti-idiotypes) obtained by immunization of animals with antibody (84). Individual antigenic determinants (idiotopes) on the variable region can be subdivided in private idiotopes that are unique for one or a few antibodies and public or cross-reactive idiotopes found on many different Ig molecules. When the interaction of anti-idiotype antibodies (that defines the idiotype) with the idiotype on an antibody is competed by antigen, the idiotype is located at or near the antigen binding site or paratope. The idiotype is associated with the framework of the antibody if the interaction of anti-idiotype with idiotype is not inhibited by antigen (86).

The fact that antibodies express cross-reactive idiotopes suggests that these antibodies are encoded by closely related variable region genes. Most detailed information about the structural basis of cross-reactive idiotopes has been obtained from antibodies against defined small haptens. Sequence analysis of anti-hapten antibodies in several idiotype systems (PC, NP, DNP, GAT, ARS, OX) demonstrated that antibodies that express the same idiotype were encoded by one or a few $V_{H}$ 


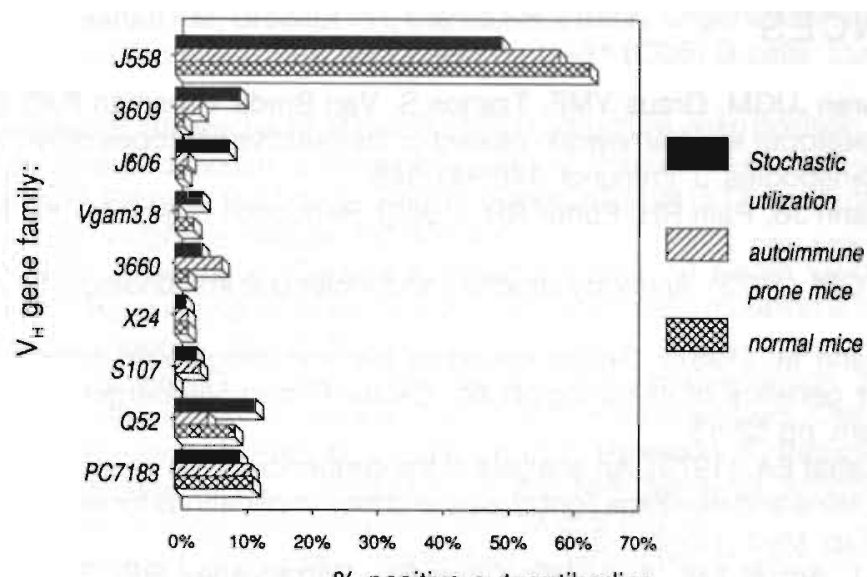

$\%$ positive autoantibodies

Figure 2: VH gene family usage of autoantibodies; accumulated data

Graphic representation of the $V_{H}$ gene family usage of autoantibodies from autoimmune prone and normal mice. The $V_{H}$ gene family usage is expressed as the percentage of mAbs positive for a given $V_{H}$ gene family and was compared to a stochastic distribution based on the estimated size of the family. The $V_{H}$ gene family utilization of autoantibodies from autoimmune prone mice represents the accumulated data of the studies presented in table 1 . The $V_{H}$ gene family utilization of autoantibodies from normal mice represents the accumulated data of the studies presented in table II.

genes $(24,26,27,86-88)$ and in most cases a restricted number of light chains (88-92). A clear example of the structural basis of a cross-reactive idiotype was demonstrated for the T15 idiotope shared by some anti-phosphorylcholine (PC) antibodies (24). The $V_{H}$ sequence of 10 out of 19 anti-PC antibodies was identical to one of the four germline genes (V1) of the $S 107 \mathrm{~V}_{H}$ gene family. The variable region of the other 9 anti-PC antibodies differed by 1-9 amino acids but were closely related to the V1 germline sequence. It was concluded that the T15 idiotype was encoded by a single S107 germline gene and that variant antibodies arose by somatic mutations.

Autoantibodies were found to be frequently idiotypically connected and express cross-reactive idiotopes $(57,58,65,93)$. A cross-reactive idiotype is often expressed by antibodies encoded by $V_{H}$ genes from a single $V_{H}$ gene family. Expression of a cross-reactive idiotype may be a marker for a $V_{H}$ gene family or subfamily (93-96). Sharing of a cross-reactive idiotype was demonstrated on antibodies against a single antigen (93-96) or on antibodies against unrelated antigens $(57,58,97)$. However, it has become apparent that antibodies can share a cross-reactive idiotype in spite of the fact that they are encoded by $V_{H}$ genes from different $V_{H}$ gene families $(57,58,97,98)$. The structural basis for such complex cross-reactive idiotypes among a heterogeneous group of antibodies is not well understood and could -in addition to similarities in $V$ genes- be correlated with $D$ and $\mathrm{J}$ gene usage or $\mathrm{V}_{H^{-}} \mathrm{D}$ or $\mathrm{D}-\mathrm{J}_{H}$ junctional similarities (99-102). 


\section{REFERENCES}

1 Verschuuren JJGM, Graus YMF, Tzartos S, Van Breda Vriesman PJC, De Baets MH. (1991). Paratope- and framework- related cross-reactive idiotopes on anti-acetylcholine receptor antibodies. J. Immunol. 146:941-948

2. Fleischmann JB, Pain RH, Porter RR. (1962). Reduction of $\gamma$-globulins. Arch. Biophys. Suppl. 1. 174-180

3 Edelman GM. (1973). Antibody structure and molecular immunology. Science 180:830840

4 Brüggemann M. (1987). Genes encoding the immunoglobulin constant regions. In: Molecular genetics of immunoglobulin. Calabi F, and Neuberger MS, Eds. Elsevier, Amsterdam. pp 52-53

5 Wu TT, Kabat EA. (1970). An analysis of the sequence of the variable regions of Bence Jones proteins and myeloma light chains and their implications for antibody complementarity. J. Exp. Med. 132:211-240

6 Poljak RJ, Amzel LM, Avey HP, Chen BL, Phizackerley RP, Saul F. (1974). The three-dimensional structure of the Fab' fragment of a human myeloma immunoglobulin at 2.0-Å resolution. Proc. Natl. Acad. Sci. USA. 71:3440-3444

7 Nishi M, Kataoka T, Honjo T. (1985). Preferential rearrangement of the immunoglobulin $\kappa$ chain joining $J_{\kappa 1}$ and $J_{\kappa 2}$ segments in mouse spleen DNA. Proc. Natl. Acad. Sci. USA. 81:2650-2654

8 Zachau HG. (1989). Immunoglobulin light-chain genes of the $\kappa$ type in man and mouse. In: Immunoglobulin genes. Honjo T, Alt FW, and Rabbits TH., Eds. Academic Press, New York. pp 91-110

9 Selsing E, Durdik J, Moore MW, Persiani DM. (1989). Immunoglobulin $\lambda$ genes. In: Immunoglobulin genes. Honjo T, Alt FW, and Rabbits TH., Eds. Academic Press, New York. pp 111-122

10 Swan D, D'Eustachio P, Leinwand L, Seidman J, Keithley D, Ruddle FH. (1979). Chromosomal assignment of the mouse $\kappa$ light chain genes. Proc. Natl. Acad. Sci. USA 76:2735-2739

11 D'Eustachio P. Bothwell ALM, Takaro TK, Baltimore D, Ruddle FH. (1981). Chromosomal localization of structural genes encoding murine immunoglobulin $\lambda$ light chains/Genetics of murine $\lambda$ light chains. J. Exp. Med. 153:793-800

12 D'Eustachio P, Pravtcheva D, Marcu K, Ruddle FH. (1980). Chromosomal localization of the structural gene cluster encoding murine immunoglobulin heavy chains, J. Exp. Med. 151:1545-1550

13 Tonegawa S. (1983). Somatic generation of antibody diversity. Nature 302:575-581

14 Rathburn G, Berman J, Yancopoulos G, Alt FW. (1989). Organization and expression of the mammalian heavy chain variable locus. In: Immunoglobulin genes. Honjo T, Alt FW, and Rabbits TH., Eds. Academic Press, New York. pp 63-90

15 Kabat EA, Wu TT, Reid-Miller M, Perry HM, Gottesman K. (1987). Sequences of immunological interest. U.S. Dept. Health and Human services.

16 Dildrop R. (1984). A new classification of mouse $V_{H}$ sequences. Immunol. Today 5:85-86

17 Brodeur PH, Riblet R. (1984). The immunoglobulin heavy chain variable region (Igh-V) locus in the mouse. I. One hundred Igh- $V$ genes comprise seven families of homologous genes. Eur. J. Immunol. 14:922-930

18 Winter E, Radbruch A, Krawinkel U. (1985). Members of a novel VH gene family are found in VDJ regions of polyclonally activated B-lymphocytes. EMBO J. 4:2861-2867

19 Kofler R. (1988). A new $V_{H}$ gene family. J. Immunol. 140:4031-4034

20 Reiniger L, Ollier P, Poncet P, Kaushik A, Jaton JC. (1987). Novel $V$ genes encode virtually identical variable regions of six murine monoclonal anti-bromelain-treated red blood cell autoantibodies. J. Immunol. 138:316-323 
21 Pennell CA, Sheenan KM, Brodeur PH, Clarke SH. (1989). Organization and expression of $V_{H}$ gene families preferentially expressed by Ly-1+(CD5) B cells. Eur. J. Immunol. 19:2115-2121.

22 Tutter A, Brodeur P, Shlomchik M, Riblet R. (1991). Structure, map position, and evolution of two newly diverged mouse ig $V_{H}$ gene families. J. Immunol. 147:3215-3223

23 Givol D, Zakut R, Effron K, Rechavi G, Ram D, Cohen JB. (1981). Diversity of the germ-line immunoglobulin $V_{H}$ genes. Nature 292:426-433

24 Crews S, Griffin J, Huang H, Calame K, Hood L. (1981). A single $V_{H}$ gene segment encodes the immune response to phosphorylcholine: somatic mutation is correlated with the class of the antibody. Cell 25:59-66

25 Livant D, Blatt C, Hood L. (1986). One heavy chain variable region gene segment subfamily in the Balb/c mouse contains 500-1000 or more members. Cell 47:461-470

26 Bothwell ALM, Paskind M, Reth M, Imanishi-Kari T, Rajewsky K, Baltimore D. (1981). Heavy chain variable region contribution to the NPb family of antibodies: somatic mutations evident in a $2 \mathrm{2a}$ variable region. Cell 24:625-637

27 Siekevitz M, Huang SY, Gefter ML. (1983). The genetic basis of antibody production: a single heavy chain variable region gene encodes all molecules bearing the dominant anti-arsonate idiotype in strain A mouse. Eur. J. Immunol. 13:123-132

28 Rathbun GA, Otani F, Milner ECB, Sanz I, Capra JD, Tucker PW. (1988). Molecular characterization of the $A / J \mathrm{~J} 558$ family of heavy chain variable region gene segments. $\mathrm{J}$. Mol. Biol. 202:383-395

29 Schiff C, Milili M, Fougereau M. (1985). Functional and pseudogenes are similarly organized and may equally contribute to the extensive antibody diversity of the $\lg V_{H} l l$ family. EMBO J. 2:1225-1230

30 Krawinkel U, Christoph T, Blankenstein T. (1989). Organization of the $\mathrm{Ig} V_{H}$ locus in mice and humans. Immunol. Today. 10:339-344

31 Sheehan KM, Brodeur PH. (1989). Molecular cloning of the primary lgH repertoire: a quantative analysis of $V_{H}$ gene usage in adult mice. EMBO J. 8:2323-2320

32 Manser T, Huang SY, Gefter ML. (1984) Influence of clonal selection on the expression of immunoglobulin variable region genes. Science 226:1283-1289

33 Dildrop R, Krawinkel U, Winter E, Rajewski K. (1985). $V_{H}$ gene expression in murine lipopolysaccharide blasts distributes over the nine known $V_{H}$ gene groups and may be random. Eur. J. Immunol. 15:1154-1156

34 Schulze DH, Kelsoe G. (1987). Genotypic analysis of B cell colonies. Stochiometric expression of three $V_{H}$ families in adult $C 57 \mathrm{bl} / 6$ and Balb/c mice. J. Exp. Med. 166:163172

35 Yancopoulos GD, Desiderio S, Paskind M, Kearney J, Baltimore D, Alt FW. (1984). Preferential utilization of the most $J_{H}$ proximal $V_{H}$ gene segments in pre-B-cell lines. Nature 311:727-733

36 Perlmutter RM, Kearny JF, Chang S, Hood LE. (1985). Developmentally controlled expression of immunoglobulin $V_{H}$ genes. Science 227:1597-1600

37 Cory S, Adams JM. (1980). Deletions are associated with somatic rearangement of immunoglobulin heavy chain genes. Cell 19:37-51

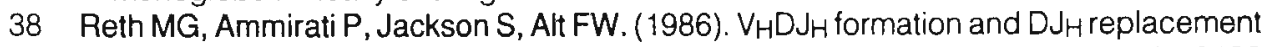
during pre-B differentiation: non-random usage of gene segments. EMBO J. 5:2131-2138

39 Rathbun GA, Capra JD, Tucker PW. (1987). Organization of the murine immunoglobulin $V_{H}$ complex in the inbred strains. EMBO J. 6:2931-2937

40 Blankenstein T, Krawinkel U. (1987). Immunoglobulin $V_{H}$ region genes of the mouse are organized in overlapping clusters. Eur. J. immunol. 17:1351-1357

41 Brodeur PH, Osman GE, Mackle JJ, Lalor TM. (1988). The organization of the mouse IgH-V locus: dispersion, interspersion and the evolution of $V_{H}$ gene family clusters. $J$. Exp. Med. 168:2261-2278 
42 Kleinfeld RW, Weigert MG. (1989). Interspersion of the $V_{H}$ Q52 and PC7 183 gene families in the NFS/N mouse. J. Immunol. 142:4483-4492

43 Meek K, Rathbun G, Reiniger L, Jaton JC, Kofler R, Tucker PW, Capra JD. (1990). Organization of the murine immunoglobulin $\mathrm{VH}$ complex: placement of two new VH families ( $\mathrm{VH} 10$ and $\mathrm{VH} 11)$ and analysis of $\mathrm{VH}$ family clustering and interdigitation. Mol. Immunol. 27:1073-1081

44 Kelsoe G, Miceli R, Cerny, Schulze DH. (1989). Mapping of antibody specificities to $V_{H}$ gene families. Immunogenetics 29:288-296

45 Jeong HD, Teale JM. (1988). Comparison of the fetal and adult functional B cell repertoires by analysis of $V_{H}$ gene family expression. J. Exp. Med. 168:589-603

46 Malynn BA, Yancopoulos GD, Barth JE, Bona CA, Alt FW. (1990). Biased expression of $\mathrm{J}_{H}$-proximal $V_{H}$ genes occurs in the newly generated repertoire of neonatal and adult mice. J. Exp. Med. 171:843-859

47 Freitas AA, Sidman CL. (1990). $V_{H}$ gene family repertoire of "viable motheaten" (mev) mice. Eur. J. Immunol. 20:1033-1037

48 Yancopoulos GD, Maylynn BA, Alt FW. (1988). Developmentally regulated and strainspecific expression of murine $V_{H}$ families. J. Exp. Med. 168:417-435

49 Wu GE, Paige CJ. (1986). VH gene family utilization in colonies derived from $B$ and pre-B cells detected by RNA colony blot assay. EMBO J. 5:3475-3481

50 Jeong HD, Komisar JL, Kraig E, Teale JM. (1988). Strain-dependent expression of $V_{H}$ gene families. J. Immunol. 140:2436-2441

51 Kastner DL, Mclntyre TM, Mallett CP, Hartmann AB, Steinberg AD. (1989). Direct quantitative in situ hybridization studies of $\mathrm{Ig} V_{H}$ utilization. J. Immunol. 143:2761-2767

52 Kaushik A, Schulze DH, Bona C, Kelsoe G. (1989). Murine $V_{K}$ gene expression does not follow the $V_{H}$ paradigm. J. Exp. Med. 169:1859-1864

53 Jeong HD, Teale JM. (1989). VH gene family repertoire of resting B cells. Preferential use of D-proximal families early in development may be due to distinct B cell subsets. J. Immunol. 143:2752-2760

54 Griffin JA, Spalding DM. (1988). VH gene expression by nontransformed pre-B cells upon differentiation in vitro. J. Immunol. 140:3982-3987

55 Bos NA, Meeuwsen CG. (1989). B cell repertoire in adult antigen-free and conventional neonatal Balb/c mice. I. Preferential utilization of the $\mathrm{C}_{H}$ proximal $\mathrm{V}_{H}$ gene family $\mathrm{PC} 7183$. Eur. J. Immunol. 19:1811-1815

56 Trepicchio W, Barrett K. (1987). Eleven MRL-Ipr/lpr anti-DNA autoantibodies are en coded by genes from four $V_{H}$ gene families: A potentially biased usage of $V_{H}$ genes. $J$. Immunol. 138:2323-2331

57 Monestier M, Manheimer-Lory A, Bellon B, Painter C, Dang H, Talal N, Zannetti M, Schwartz R, Pisetsky D, Kuppers R, Rose N, Brochier J, Klaresog L, Holmdahl R, Erlanger B, Alt F, Bona C. (1986). Shared idiotopes and restricted immunoglobulin variable region heavy chain genes characterize murine autoantibodies of various specificities $\mathrm{J}$. Clin. Invest. 78:753-759

58 Bellon B, Manheimer-Lory A, Monestier M, Dimitriu-Bona A, Alt F, Bona C. (1987). High frequency of autoantibodies bearing cross-reactive idiotopes among hybridomas using $V_{H} 7183$ genes prepared from normal and autoimmune murine strains. J. Clin. Invest. 79:1044-1053

59 Holmberg D. (1987). High connectivity, natural autoantibodies preferentially use 7183 and Q52 VH gene families. Eur. J. Immunol. 17:399-403

60 Dighiero G, Lymberi P, Holmberg D, Lundquist I, Couthinio A, Avrameas S. (1985). High frequency of natural autoantibodies in normal newborn mice. J. Immunol. 134:765-771

61 Hayakawa K, Hardy RR, Parks DR, Herzenberg. (1983). The Ly-1 B cell subpopulation in normal, immunodeficient and autoimmune mice. J. Exp. Med. 157:202-218 
62 Casali P, Burastero SE, Nakamura M, Inghirami G, Notkins AL. (1987). Human lymphocytes making rheumatoid factor and antibody to SSDNA belong to Leu-1+ B-cell subset. Science 236:77-81

63 Stevenson FK. (1986). Idiotypes and diseases. Immunol. Today 7:287-288

64 Shultz LD. (1988). Pleiotropic effects of deleterious alleles at the "motheaten" locus. Curr. Top. Microbiol. Immunol. 137:217-222

65 Manheimer-Lory A, Monestier M, Bellon B, Alt F, Bona A. (1986). Fine specificity, idiotype, and nature of cloned heavy-chain variable region genes of murine monoclonal rheumatoid factor antibodies. Proc. Natl. Acad. Sci. USA. 83:8293-8297

66 Bona C, Kasturi KN, Mayer R, Fidanza V. (1988). V gene usage by autoantibodies and their polymorphism in autoimmune mice. Autoimmunity 2:39-53

67 Arant SE, Griffin JA, Koopman WJ. (1986). VH gene expression is restricted in anti-IgG antibodies from MRL autoimmune mice. J. Exp. Med. 164:1284-1300

68 Agauado MT, Balderas RS, Rubin RL, Duchosal MA, Kofler R, Birshtein BK, Secher DS, Dixon FJ, Theofilopoulos AN. (1987). Specificity and molecular characteristics of monoclonal lgM rheumatoid factors from arthritic and non-arthritic mice. J. Immunol. 139:1080-1087

69 Komisar JL, Leung KY, Crawley RR, Talal N, Teale JM. (1989). Ig VH gene family repertoire of plasma cells derived from lupus-prone $M R L / p r$ and $M R L /++$ mice. $J$. Immunol, 143:340-347

70 Kofler R, Noonan DJ, Strohal R, Balderas RS, Moller NPH, Dixon FJ, Theofilopoulos AN. (1987). Molecular analysis of the murine lupus-associated anti-self response: Involvement of a large number of heavy and light chain variable region genes. Eur. J. Immunol. 17:91-95

71 Striebich CC, Miceli RM, Schulze DH, Kelsoe G, Cerny J. (1990). Antigen-binding repertoire and $\mathrm{Ig} H$ chain gene usage among $B$ cell hybridomas from normal and autoimmune mice. J. Immunol. 144:1857-1865

72 Painter CJ, Monestier M, Chew A, Bona-Dimitriu A, Kastoury K, Bailey C, Scott VE, Sidman CL, Bona CA. (1988). Specificities and V genes encoding monoclonal autoantibodies from viable motheaten mice. J. Exp. Med. 167:1137-1153

73 Reiniger L, Shibata T, Ozaki S, Shirai T, Jaton JC, Izui S. (1990). Variable region sequences of pathogenic anti-mouse red blood cell autoantibodies from autoimmune NZB mice. Eur. J. Immunol. 20:771-777

74 Panosian-Sahakian N, Klotz JL, Ebling F, Kronenberg M, Hahn B. (1989). Diversity of Ig $V$ gene segments found in anti-DNA autoantibodies from a single (NZBXNZW) $F_{1}$ mouse. J. immunol. 142:4500-4506

75 Hayakawa K, Carmak CE, Hyman R, Hardy RR. (1990). Natural autoantibodies to thymocytes: origin, $V_{H}$ genes, fine specificities, and the role of Thy- 1 glycoprotein. $\mathrm{J}$. Exp. Med. 172:869-878

76 Hartman AB, Mallet CP, Srinivasappa J, Prabhakar BS, Notkins AL, Smith-Gill SJ. (1989) Organ reactive autoantibodies from non-immunized adult Balb/c mice are polyreactive and express a non-biased $V_{H}$ gene usage. Mol. Immuol. 26:359-370

77 Shlomchik MJ, Nemazee DA, Sato VL. van Snick J, Carson DA, Weigert MG. (1986). Variable region sequences of murine $\operatorname{lgM}$ anti-lgG monoclonal autoantibodies (rheumatoid factors). A structural explanation for the high frequency of $\operatorname{lgM}$ anti-lgG $B$ cells. J. Exp. Med. 164:407-427

78 Souroujon M, White-Scharf ME, Andre-Schwartz J, Gefter ML,Schwartz RS. (1988). Preferential autoantibody reactivity of the preimmmune $B$ cell repertoire in normal mice. J. Immunol. 140:4173-4179

79 Ewulona UK, Nell LJ, Thomas JW. (1990). $V_{H}$ and $V_{L}$ gene usage by murine IgG antibodies that bind autologous insulin J. Immunol. 144:3091-3098 
80 Rolink AG, Radaszkiewicz T, Melchers F. (1988). Monoclonal autoantibodies specific for kidney proximal tubular brush border from mice with experimentally induced chronic graft-versus-host disease. Scand. J. Immunol. 28:29-41

81 Holmdahl R, Bailey C, Enander I, Mayer R, Klareskog L, Moran T, Bona C. (1989). Origin of the autoreactive anti-type II collagen response; II. Specificities, Antibody idiotypes and usage of $V$ gene families of anti-type II collagen B cells. J. Immunol. 142:1881-1886

82 Gleason GL, Gearhart P, Rose NA, Kuppers RC. (1990). Autoantibodies to thyroglobulin are encoded by diverse V-gene segments and recognize restricted epitopes. J. Immunol. 145:1768-1775

83 Rolink AG, Thalmann P, Berger C, Radaszkiewicz T, Melchers F. (1988). Autoreactive $\mathrm{B}$-cell repertoire in mice with chronic graft versus host disease. Mol. Immunol. 25:12171222

84 Eichmann K. (1978). Expression and function of idiotypes on lymphocytes. Adv. Immunol. 26:195-254

85 Rajewski K, Takamori T. (1983). Genetics, expression, and function of idiotypes. Ann. Rev. Immunol. 1:569-607

86 Kaartinen M, Gillian GM, Markham AF, Milstein C. (1983). mRNA sequences define an unusually restricted $\lg$ G response to 2-phenyloxazolone and its early diversification. Nature 304:3209-324

87 Loh DY, Bothwell ALM, White-Scharf ME, Imanishi-Kari T, Baltimore D. (1983). Molecular basis of a mouse strain-specific anti-hapten response. Cell 33:85-93

88 Sanz I, Capra JD. (1987) $V_{K}$ and $J_{K}$ gene segments of AJ Ars-A antibodies: somatic recombination generates the essential arginine at the junction of the variable and joining regions. Proc. Natl. Acad. Sci. USA 84:1085-1089

89 Wysocki LJ, Gridley T, Huang S-Y, Grandea AG, Gefter ML. (1987). Single germline $V_{H}$ and $V_{K}$ genes encode predominating antibody variable regions elicited in strain A mice by immunization with p-azophenyl arsonate. J. Exp. Med. 166:1-11

90 Even J, Griffiths JM, Berek C, Milstein C. (1985). Light chain germ-line genes and the immune response to 2-phenyloxazolone. EMBO J. 4:3439-3445

91 Corbet S, Milili M, Fougereau M, Schiff C. (1987). Two $V_{K}$ germ-line genes related to the GAT idiotypic network (Ab1 and Ab3/Ab1') account for the major subfamilies of the mouse $V_{K}$-1 variability subgroup. J. Immunol. 138:932-939

92 Dzierzak EA, Janeway CA jr, Richard N, Bothwell A. (1986). Molecular characterization of antibodies bearing $1 \mathrm{~d}-460$. I. The structure of two highly homologous $V_{H}$ genes used to produce idiotype positive immunoglobulins. J. Immunol. 136:1864-1870

93 O'Keefe TL, Bandyopadhyay S, Datta SK, Imanishi-Kari T. (1990). V region sequences of an idiotypically connected family of pathogenic anti-DNA autoantibodies. J. Immunol. 144:4275-4283

94 Victor-Kobrin C, Mansner T, Moran TM, Imanishi-Kari, Gefter M, Bona CA. (1985). Shared idiotopes among antibodies encoded by heavy-chain variable region $\left(\mathrm{V}_{\mathrm{H}}\right)$ gene members of the $J 558 \mathrm{~V}_{H}$ family as basis for cross-reactive regulation of clones with different antigen specifity. Proc. Natl. Acad. Sci. USA 82:7696-7700

95 Nahmias C, Cazaubon S, Strosberg AD. (1989). A rabbit antiserum detects a $V_{H} J 558$ subgroup marker highly expressed among anti-alprenolol antibodies. J. Immunol. 142:871-876

96 Hirashima K, Zenita K, Takada A, Kitahara A, Ishihara G, Harada R, Ohmori K, Hirohashi S, Kyoizumi S, Akiyama M, Kannagi R. (1990). High idiotypic connectivity of the $V_{H}$ 7183-encoded antibodies directed to a murine carbohydrate antigen, Lewis $Y$, as ascertained by syngeneic anti-idiotype monoclonal antibodies. J. Immunol. 145:224-232

97 Painter C, Monestier M, Binin B, Bona C. (1986). Functional and molecular studies of V genes expressed in autoantibodies. Immunol. Rev. 94:75-98 
98 Victor-Kobrin C, Barak ZT, Bonilla FA, Kobrin B, Sanz I, French D, Rothe J, Bona C. (1990). A molecular and structural analysis of the $V_{H}$ and $V_{K}$ regions of monoclonal antibodies bearing the A48 regulatory idiotype. J. Immunol. 144:614-624

99 Pollock BA, Kearney JF, Vakil M, Perry RP. (1984). A biological consequence of variation in the site of $D-J_{H}$ gene rearrangement. Nature 311:376-379

100 Radbruch A, Zaiss S, Kappen C, Bruggeman M, Beyreuther K, Rajewski K. (1985). Drastic change in idiotypic but not antigen-binding specificity of an antibody by a single amino-acid substitution. Nature 315:506-508

101 Meek K, Jeske D, Slaovi M, Leo M, Urbain J, Capra JD. (1984). Complete amino acid sequence of heavy chain variable regions derive from two monoclonal anti-p-Azophenylarsonate antibodies of Balb/c mice expressing the major cross-reactive idiotype of the A/J strain. J. Exp. Med. 160:1070-1086

102 Boersch-Supan ME, Agrawal S, White-Scharf ME, Imanishi-Kari T. (1985). Heavy chain variable region. Multiple gene segments encode anti-4-hydroxy-3-nitrophenyl-acetyl idiotypic antibodies. J. Exp. Med. 161:1271-1292

103 Foster MH, Mac Donald M, Barret KJ, Madaio MP. (1991). VH gene analysis of spontaneously activated $B$ cells in adult MRL-Ipr/lpr mice. J. Immunol. 147:1504-1511

104 Verschuuren JJGM, Graus YMF, van Breda Vriesman PJC, Tzartos S, De Baets MH. (1991). In vivo effects of neonatal administration of anti-idiotype antibodies on experimental autoimmune myasthenia gravis. Autoimmunity. 10:173-179 


\section{Chapter 4}

Characterization of anti-acetylcholine receptor antibodies from mice differing in susceptibility for experimental autoimmune myasthenia gravis

Yvo M.F. Graus, Peter J.C. van Breda Vriesman, and Marc H. De Baets 


\section{Characterization of anti-acetylcholine receptor antibodies from mice differing in susceptibility for experimental autoimmune myasthenia gravis}

In the murine model for experimental autoimmune myasthenia gravis (EAMG) we investigated the relation between disease susceptibility and fine specificity of anti-AChR antibodies obtained from high susceptible C57bl/6 and low susceptible Balb/c mice after immunization with Torpedo AChR. Monoclonal anti-AChR antibodies with fine specificity for the main immunogenic region (MIR), the $\alpha$-bungarotoxin/acetylcholine $(\alpha-\mathrm{BT})$ binding sites and other extraand intracellular epitopes were isolated from both mouse strains. The relative frequencies of hybridomas cross-reactive with autologous mouse AChR, or directed against the MIR and the $\alpha$-BT binding site were higher in $C 57 \mathrm{bl} / 6$ than in Balb/c mice. This observed difference in anti-AChR repertoire was evaluated in the polyclonal anti-AChR response of EAMG mice. However, the concentration of antibodies directed against the MIR and $\alpha$-BT binding site in the sera of both mouse strains were found to be similar after secondary immunization. These results indicate that strain specific differences in disease susceptibility in murine EAMG are not related to differences in the overall concentration of antibodies against the MIR or $\alpha$-BT binding site. 


\section{INTRODUCTION}

In myasthenia gravis, the acetylcholine receptor is target of an autoimmune response (1). The nicotinic acetylcholine receptor involved in the signal transmission at the neuromuscular junction, is a transmembrane glycoprotein composed of five subunits in the stochiometry $\alpha_{2} \beta \varepsilon \delta$ (2). The extracellular domain of the $\alpha$-subunits contain the cholinergic binding site (3) and a main immunogenic region (MIR) against which a major part of the anti-AChR antibodies in MG and EAMG is directed $(4,5)$. Anti-AChR antibodies decrease or inactivate functional AChR resulting in an impaired neuromuscular transmission. In MG, functional AChR can be inactivated by several mechanisms. Antibodies bound to AChR can activate complement leading to focal lysis of the postsynaptic membrane $(6,7)$. Anti-AChR antibodies cause accelerated receptor turnover by cross-linking AChRs, resulting in a diminished number of functional AChR molecules $(8,9)$. Furthermore, AChRs can be functionally inactivated by antibodies interfering with acetylcholine binding (10), or by impairment of the ion channel function of the $\operatorname{AChR}(11,12)$. Differences in antibody fine specificities contributing to these pathogenic mechanisms may influence the severity of the disease since the total anti-AChR antibody titer in MG and EAMG does not closely correlate with the severity of the disease (44).

Differences in susceptibility for EAMG are found among different strains of mice (13, $14,15)$ and rats $(16)$. Susceptibility to EAMG in mice is controlled by multiple genes including the class II MHC, and genes that control complement activity (15). In addition, strain specific differences in the available anti-AChR antibody repertoire could contribute to disease susceptibility. In this report a possible relation between antibody fine specificity and disease susceptibility was investigated. Anti-AChR mAbs directed against the MIR, the $\alpha$-BT binding site and other extra- and intracellular epitopes were isolated from both high susceptible $C 57 \mathrm{bl} / 6$ and low susceptible $\mathrm{Balb} / \mathrm{c}$ mice. The relative frequencies of mAbs against well defined epitopes on AChR in the clonable anti-AChR repertoire of both mice strains were determined.

MAbs cross-reactive with mouse AChR (MAChR), or directed against the MIR and the $\alpha$-BT binding site were more frequently found in EAMG susceptible C57bl/6 mice whereas mAbs against an intracellular epitope were more frequently found in Balb/c mice. Possible differences in the available anti-AChR antibody repertoire were also evaluated in IgG obtained from EAMG and control mice. C57bl/6 and Balb/c mice showed similar concentrations of antibodies against the MIR and the $\alpha$-BT binding site, in contrast with differences in the relative frequencies of these specificities found in the clonable repertoire. These results indicate that disease susceptibility in murine EAMG is not determined by major differences in the antiAChR repertoire.

\section{MATERIAL AND METHODS}

\section{Animals and antigens}

8 wk old $\mathrm{C} 57 \mathrm{bl} / 6$ and Balb/c mice were purchased from Charles River Wiga $\mathrm{GmbH}$, Frankfurt, FRG and were maintained under specific pathogen free conditions. AChR from electric organ of Torpedo californica (Pacific Biomarine, California, USA) was 
purified by affinity chromatography on Naja naja siamensis toxin (Miami Serpentarium, Florida, USA) linked to Sepharose-4B (Pharmacia LKB, Woerden, The Netherlands) (17).

\section{Production and screening of hybridomas}

Mice were immunized with $15 \mu \mathrm{g}$ purified tAChR in CFA. Animals were boosted 3 and 5 weeks after primary immunization with $15 \mu \mathrm{g} \mathrm{AChR} \mathrm{in} \mathrm{IFA.} \mathrm{Animals} \mathrm{were}$ sacrificed three days after the last booster injection and cells of para-aortal, inguinal and poplitial lymphnodes were fused with the mouse tumor cell line SP2/0-Ag14 according to Köhler and Milstein (18). Hybridomas were initially screened for reactivity to tAChR by an ELISA

96 wells polystyrene microtiter plates (Greiner, Alphen a/d Rijn. The Netherlands) were coated with $5 \mu \mathrm{g} / \mathrm{ml}$ AChR or $\mathrm{KLH}$ in $10 \mathrm{mM}$ sodiumbicarbonate buffer $\mathrm{pH}=9.5$ for $1 \mathrm{hr}$ at $37{ }^{\circ} \mathrm{C}\left(50 \mu / /\right.$ well). After washing three times with $\mathrm{H}_{2} \mathrm{O}$ containing $0.5 \%$ Tween-20 $\left(\mathrm{H}_{2} \mathrm{O} / \mathrm{Tw}\right)$, plates were incubated for $15 \mathrm{~min}$ with PBS containing $0.5 \%$ BSA and $0.5 \%$ Tween-20 (PBSA $/ \mathrm{T} w$ ) to occupy remaining bindingsites. Plates were incubated with $100 \mu \mathrm{l}$ of hybridoma culture supernatant for $18 \mathrm{hr}$ on a rocking platform. After washing with $\mathrm{H}_{2} \mathrm{O} / \mathrm{Tw}$ the wells were incubated for $1 \mathrm{hr}$ at roomtemperature (R.T.). with rabbit-anti-mouse Ig coupled to HRP (Dako ITK diagnostics, Uithoorn, The Netherlands) on a rocking platform. After washing with $\mathrm{H}_{2} \mathrm{O} / \mathrm{Tw}$ the colorimetric reaction was performed by adding $100 \mu \mathrm{l}$ of $110 \mathrm{mM}$ sodiumacetate buffer, $\mathrm{pH} 5.5$, containing $100 \mu \mathrm{g} / \mathrm{ml} \mathrm{TMB}$ and $0.01 \% \mathrm{H}_{2} \mathrm{O}_{2}$. The colorreaction was stopped after 10 minutes by adding $50 \mu \mathrm{l} 4 \mathrm{n} \mathrm{H}_{2} \mathrm{SO}_{4}$. The optical density was measured at $450 \mathrm{~nm}$ using a Titertek Twinreader (Amstelstad, Amsterdam, The Netherlands).

\section{Fine specificity of anti-AChR mAbs}

MAbs were screened for binding to extra- and intracellular located epitopes on AChR rich membrane vesicles (liposomes). Flexible PVC 96 wells ELISA plates (Flow ICN, Amsterdam, The Netherlands) were coated with protein G purified mAb $(25 \mu \mathrm{g} / \mathrm{ml})$ for $1 \mathrm{hr}$ at $37^{\circ} \mathrm{C}$. Plates were washed and preincubated as described above. Coated plates were incubated with $150 \mu \mathrm{AChR}$ rich membrane vesicles ( 80 femtomoles AChR) labeled with $125 \mid-\alpha$-BT for 16 hrs at $4{ }^{\circ} \mathrm{C}$. Membrane vesicles rich in AChR were isolated from electric organ of Torpedo californica as described previously (17). After washing the plates with PBS buffer containing $0.5 \%$ Triton $X-100$ (Sigma/Brunschwig chemie, Amsterdam, The Netherlands) and $0.02 \% \mathrm{NaN}_{3}$ (PBS/TX), bound radioactivity was counted in a gamma counter.

MAbs were screened for reactivity to the MIR of the AChR by a competitive inhibition ELISA using mAb 35 as a reference anti-MIR antibody. Briefly, 96 wells ELISA plates were coated with $5 \mu \mathrm{g} / \mathrm{ml}$ purified AChR $(50 \mu \mathrm{l})$ and incubated for $1 \mathrm{hr}$ with $50 \mu \mathrm{l}$ anti-AChR mAb with increasing concentration $(0.001-10 \mu \mathrm{g} / \mathrm{ml})$. Subsequently, plates were incubated for $1 \mathrm{hr}$ with $50 \mu \mathrm{lHRP}$ conjugated mAb $35(0.04 \mu \mathrm{g} / \mathrm{ml}, 50$ $\%$ of maximum binding to AChR) without washing and bound mAb 35-HRP was measured. The results are expressed as percentage inhibition of mAb 35-HRP binding and calculated as follows: 
[(average $A_{450}$ of duplicate wells with $\mathrm{MAb} 35-\mathrm{HRP}$ alone - average $A_{450}$ of duplicate wells in which mAb 35-HRP was tested in the presence of putative anti-MIR mAb)/average $A_{450}$ of duplicate wells with mAb 35-HRP alone]x100.

MAbs were considered to be directed to the MIR when binding of MAb 35-HRP to AChR was inhibited by more than $50 \%$ (21).

MAbs were also tested for there ability to inhibit the binding of $125 \mid-\alpha$-BT to AChR by the following assay: 96 wells flexible ELISA plates were coated with Torpedo AChR $(5 \mu \mathrm{g} / \mathrm{ml})$ and incubated with $100 \mu$ l hybridoma supernatant or purified mAb at R.T. for 16 hrs. After incubation the supernatant was removed by aspiration and plates were subsequently incubated with a limiting concentration of ${ }^{125} \mid-\alpha$-BT (2 picomoles/ml) for 2 hrs at R.T.. Plates were washed and bound radioactivity counted as described above. Results are expressed as percentage inhibition of $125 \mid-\alpha-B T$ binding to AChR. The percentage inhibition was calculated as follows:

[(average cpm of duplicate wells with ${ }^{125} \mid-\alpha$-BT alone - average cpm of duplicate wells with ${ }^{125}-\alpha-B T$ in the presence of putative inhibitor mAb)/average $\mathrm{cpm}$ of duplicate wells with ${ }^{125}$ - $\alpha$-BT alone] $\times 100$.

\section{Cross-reaction with mAChR}

Anti-AChR mAbs were screened for cross-reactivity to mAChR by a liquid phase precipitation radio immunoassay (RIA) (19), or solid phase radio immunoassay (SPRIA) in which binding of $125 \mid-\alpha$-BT labeled mAChR to solid phase bound mAbs was tested. MAbs that failed to precipitate MAChR in the RIA were purified from hybridoma supernatant, coated to ELISA plates and tested for ${ }^{125} \mathrm{I}-\alpha$-BT-mAChR binding; mAbs purified on protein G Sepharose-4B were coated on 96 wells PVC ELISA plates $(25 \mu \mathrm{g} / \mathrm{ml})$. Plates were subsequently incubated overnight at $4^{\circ} \mathrm{C}$ with $150 \mu \mathrm{l}$ of ${ }^{125} \mathrm{l}-\alpha$-BT-mAChR (0.6 nM). After incubation plates were washed and bound radioactivity counted as described above. MAbs against KLH and thyroglobulin (22) were used as negative controls.

In addition mAbs cross-reactive with mAChR were tested for binding to neuromuscular junctions in cryosections of mouse extensor digitorum longum muscle by immunofluorescence (20). Briefly, cryosections fixed for $10 \mathrm{~min}$ in icecold aceton were incubated with $25 \mu$ l hybridoma supernatant or purified mAb $(20-100 \mu \mathrm{g} / \mathrm{ml})$ for $1 \mathrm{hr}$. Bound antibody was visualized by fluorescence microscopy using FITCconjugated goat- $F(a b)_{2}$-anti mouse Ig (Cappel, Organon Technika, Boxtel, The Netherlands).

\section{Antibody isotype}

The isotypes of monoclonal antibodies were determined using a mouse mAb isotyping kit (Holland Biotechnology, Leiden, The Netherlands).

\section{Passive transfer of anti-AChR $m A b$}

Eight week old $\mathrm{C} 57 \mathrm{bl} / 6$ mice were injected intraperitoneal with $1 \mathrm{~m} / 20 \mathrm{gr}$ bodyweight $\mathrm{mAb} 60$ ascitic fluid having a $\mathrm{mAChR}$ binding capacity of $45 \mathrm{pmol} / \mathrm{ml}$. Control animals were injected with PBS. Animals were killed at $48 \mathrm{hrs}$ after injection for determination of AChR concentration. 


\section{Induction of chronic EAMG}

EAMG was induced in mice by immunization with $15 \mu \mathrm{g}$ tAChR emulsified in CFA at the base of the tail and both footpads and boosted with $15 \mu \mathrm{g}$ AChR in IFA after 31 days.

\section{Anti-mAChR antibody titer}

Antibody titers against mAChR were measured by immunoprecipitation using ${ }^{125}$ $\alpha$-BT labeled mAChR according to Lindstrom et al (19) with minor modifications. A crude extract of denervated mouse muscle AChR (approximately 0.6 nanomoles mAChR/I) was labeled with $2 \times 10^{-9} \mathrm{M}^{125} \mid-\alpha-B T$ for 4 hrs at $4{ }^{\circ} \mathrm{C}$. Diluted serum samples $(5 \mu)$ ) were incubated with $200 \mu$ l $1251-\alpha$-BT-mAChR overnight at $4^{\circ} \mathrm{C}$. Antibody-AChR complexes were precipitated by adding excess goat-anti-mouse Ig antibodies. After $4 \mathrm{hrs}$ at $4^{\circ} \mathrm{C}$ samples were centrifuged for $3 \mathrm{~min}$ in an Eppendorf centrifuge and subsequently washed once with $1 \mathrm{ml}$ PBS buffer containing $0.5 \%$ Triton-X100 (Sigma, Brunschwig chemie b.v., Amsterdam, The Netherlands) and $0.02 \% \mathrm{NaN}_{3}$ (PBS/TX). Radioactivity was counted in a gamma counter (Compugamma, Pharmacia LKB, Woerden. The Netherlands), Values of $1251-\alpha$-BT-mAChR pelleted in the presence of normal mouse serum were considered background and subtracted from the assay values. The antibody titers were expressed as moles of $125 \mathrm{I}-\alpha$-BT binding sites per liter.

\section{Antibody specificity in EAMG sera}

Antibodies directed to the MIR and the $\alpha$-BT binding site in the sera of EAMG mice were determined using a competitive inhibition ELISA. Sera obtained from C57bl/6 and $\mathrm{Balb} / \mathrm{c}$ mice were pooled and IgG was purified by affinity chromatography on protein G sepharose (Pharmacia LKB, Woerden, The Netherlands). EAMG or controle $\operatorname{lgG}(0.0005-50 \mu \mathrm{g} / \mathrm{ml})$ was used to inhibit the binding of reference anti-MIR mAb 35 or $\alpha$-BT as described above. Results are expressed as percentage inhibition of mAb 35 -HRP or ${ }^{125} \mid-\alpha$-BT binding to AChR.

\section{Quantitation of $A C h R$ in muscle}

The concentration of AChR was determined in whole carcasses according to Lindstrom et al (19) with modifications as previously described (43). The AChR concentration in muscle was expressed as pmol AChR/100 gr muscleweight.

\section{RESULTS}

\section{Anti-AChR mAbs from C57bl/6 and Balb/c mice}

Monoclonal antibodies directed against $A C h R$, were obtained from three separate fusions using pooled lymphnode cells from C57bl/6 $(n=3)$ and Balb/c $(n=3)$ mice immunized three times with AChR from Torpedo californica. Hybridomas were screened for binding to tAChR. Anti-AChR mAbs were of the $\kappa$-light chain type and $\operatorname{lgG}_{1}(35 \%), \lg G_{2 a}(13 \%), \lg _{2 b}(26 \%), \lg A(6 \%)$ and $\lg M(9 \%)$ isotypes. All characteristics of anti-tAChR mAbs are summarized in table I. 


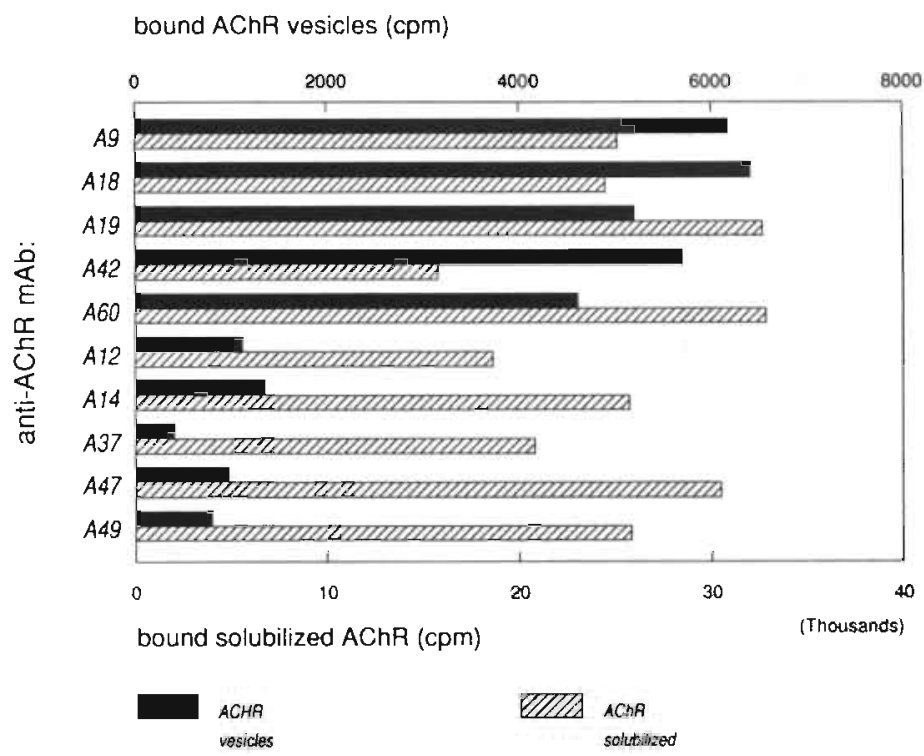

Figure 1: Membrane bound AChR only binds to mAbs against extracellular epitopes.

Anti-AChR mAbs were tested for binding to solubilized AChR or AChR vesicles in which the receptor is embedded in the membrane and only extracellular epilopes are exposed. The striped bars represent the binding of solubilized AChR to solidphase MAbs. The solid bars represent the binding of AChR vesicles to mAbs.

\section{MAbs against extra- and intracellular epitopes}

The AChR is a transmembrane glycoprotein with extracellular epitopes accessible for antibody in vivo and intracellular epitopes only accessible on solubilized AChR in vitro. Since anti-AChR mAbs are generated against solubilized AChR both antibodies against extra- and intracellular epitopes will arise. MAbs binding to extracellular epitopes can be discriminated from mAbs to intracellular epitopes by binding to AChR rich membrane vesicles. Thirty-seven out of $65 \mathrm{mAbs}$ bound to both membrane incorporated and solubilized AChR, whereas 12 out of $65 \mathrm{mAbs}$ bound to solubilized but not membrane incorporated AChR. Binding of representative mAbs to solubilized or membrane bound tAChR are shown in figure 1 .

\section{MAbs directed to the main immunogenic region}

In both MG and EAMG it was reported that the major part of pathogenic antibodies is directed against the MIR; a 10 amino acid epitope on the $\alpha$-subunit of the AChR. Seventeen out of 65 mAbs were directed against the MIR as was determined by competitive inhibition with reference rat anti-MIR mAb 35. Representative inhibition curves and the concentrations of anti-MIR mAbs needed for $50 \%$ inhibition $\left(I_{50}\right)$ are shown in figure 2 . 
Table I: Characteristics of anti-AChR mAbs.

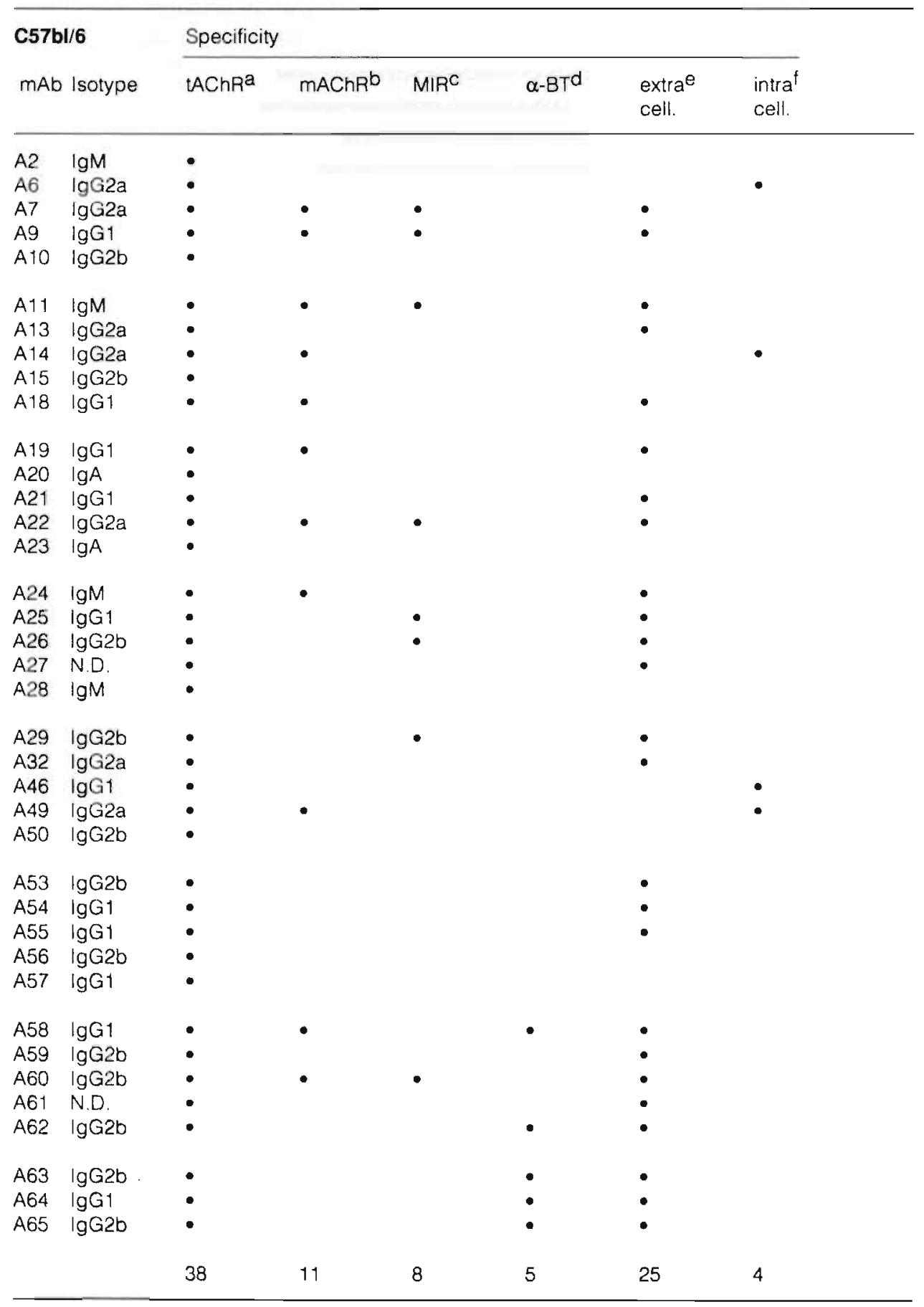




\begin{tabular}{|c|c|c|c|c|c|c|c|}
\hline \multirow{2}{*}{\multicolumn{2}{|c|}{$\begin{array}{l}\text { Balb/c } \\
\text { mAb Isotype }\end{array}$}} & \multicolumn{6}{|c|}{ Specificity } \\
\hline & & \multirow{2}{*}{ tAChR $^{a}$} & \multirow[t]{2}{*}{$\mathrm{mAChR}^{\mathrm{b}}$} & \multirow{2}{*}{$\begin{array}{l}M I R^{C} \\
\end{array}$} & \multirow[t]{2}{*}{$\alpha-B T^{d}$} & \multirow{2}{*}{$\begin{array}{l}\begin{array}{l}\text { extrae } \\
\text { cell. }\end{array} \\
\end{array}$} & \multirow[t]{2}{*}{$\begin{array}{l}\text { intraf } \\
\text { cell. }\end{array}$} \\
\hline $\mathrm{A} 1$ & $\lg G 1$ & & & & & & \\
\hline $\mathrm{A} 3$ & $\lg M$ & $\bullet$ & & $\cdot$ & & $\bullet$ & \\
\hline A4 & $\lg G 2 a$ & - & & & & - & \\
\hline A5 & $\lg A$ & - & & & & & \\
\hline$A 8$ & $\mid g G 1$ & $\bullet$ & & & - & - & \\
\hline A12 & $\lg G 1$ & - & - & & & & - \\
\hline A16 & $\operatorname{lgG} 1$ & - & & & & & \\
\hline $\mathrm{A} 17$ & $\lg A$ & - & & & & & \\
\hline A30 & $\lg G 1$ & - & & & & & - \\
\hline A31 & $\lg \mathrm{G} 1$ & - & & & & & \\
\hline A33 & $\operatorname{lgG} 2 \mathrm{a}$ & - & & & & & \\
\hline A34 & $\lg G 2 b$ & $\bullet$ & & - & & - & \\
\hline A35 & $\operatorname{lgG} 2 b$ & - & & - & & - & \\
\hline A36 & $\lg G 1$ & $\bullet$ & & - & & - & \\
\hline A37 & $\operatorname{lgG1}$ & • & • & & & & - \\
\hline A38 & $\operatorname{lgG} 2 b$ & $\bullet$ & & - & & - & \\
\hline A39 & $\lg G 2 b$ & $\bullet$ & & - & & - & \\
\hline A40 & $\lg G 1$ & - & & - & & - & \\
\hline A41 & $\operatorname{lgG} 1$ & - & & - & & - & \\
\hline A42 & $\lg G 1$ & - & - & & & & \\
\hline A43 & $\operatorname{lgG} 1$ & - & - & & & - & \\
\hline A44 & $\lg G 2 b$ & - & & & & & $\bullet$ \\
\hline A45 & $\lg M$ & - & & & & & $\bullet$ \\
\hline A47 & $\operatorname{lgG} 2 a$ & - & - & & & & - \\
\hline A48 & $\operatorname{lgG} 2 a$ & - & & & & & $\bullet$ \\
\hline A51 & $\lg G 2 b$ & - & & & & & \\
\hline \multirow[t]{2}{*}{ A52 } & $\lg G 2$ & • & & & & & \\
\hline & & 27 & 5 & 9 & 1 & 12 & 7 \\
\hline
\end{tabular}

Isotype and specificity of mAbs directed to AChR raised in EAMG high susceptible C57b//6 and low susceptible Balb/c mice. ${ }^{a}$ All mAbs are specific for AChR of Torpedo californica. ${ }^{b}$ MAbs cross-reactive with solubilized $A C h R$ from denervated mouse muscle. ${ }^{C}$ MIR: the main immunogenic region located on the $\alpha$-subunit ( $\alpha 67-76$ ) of AChR. ${ }^{d} \alpha-B T$ : the $\alpha$-bungarotoxin binding site on the $\alpha$-subunit ( $\alpha$ 189-195) of AChR ${ }^{\theta}$ Extracell.: epitopes located on the extracellular surface of AChR. Intracell. : epitope s located on the cytoplasmic surface of AChR only accessible on solubilized receptor.

\section{MAbs directed to the $\alpha$-bungarotoxin binding site}

Six anti-AChR mAbs were directed to the binding site for $\alpha$-BT which coincides with the binding site for acetylcholine. Four mAbs (A8, A58, A64 and A65) were able to block the binding of ${ }^{125} \mid-\alpha$-BT to AChR for more than $80 \%$ suggesting that these 
A

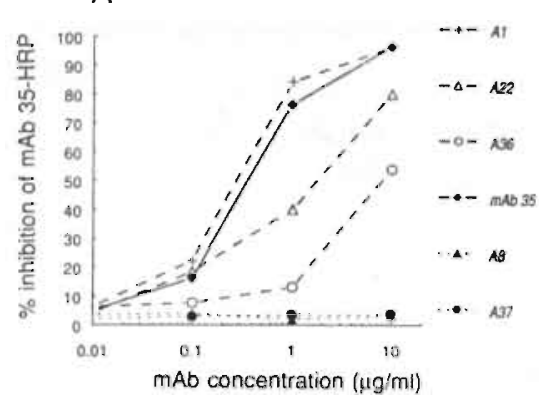

B

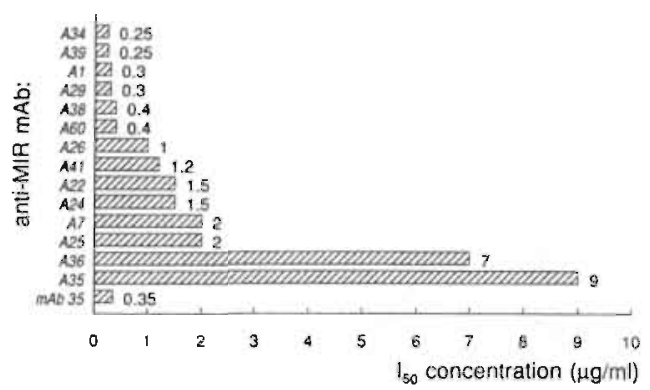

Figure 2: Competitive inhibition of reference anti-MIR mAb 35 binding to AChR by anti-AChR mAbs. (A) Representative inhibition curves are shown in which the binding of HRP conjugated mAb 35 to AChR was inhibited by mouse anti-MIR MAbs. MAbs which inhibited the binding of mAb 35 by more than $50 \%$ were considered to be directed to the MIR (42). Non-MIR mAbs A8 (directed to the $\alpha-B T$ binding site on the $\alpha$-subunit) and A37 (directed to a cytoplasmic epitope on the $\alpha$-subunit) did not show any inhibition of mAb 35 binding.

(B) Differences in affinity or fine specificity of anti-MIR mAbs are represented by the concentrations of anti-AChR mAbs needed for $50 \%$ inhibition of MAb $35-$ HRP binding to AChR (I 50 ).

mAbs recognized both $\alpha$-BT binding sites, whereas mAb A62 and A63 only inhibited ${ }^{125} \mid-\alpha$-BT binding around $50 \%$, suggesting that these mAbs only recognized one of the two $\alpha$-BT binding sites on each AChR molecule (fig. 3).

\section{Cross-reaction with $\mathrm{mAChR}$}

The cross-reaction of mAbs against tAChR with MAChR was determined either by direct binding of ${ }^{125} \mid-\alpha$-BT-mAChR to solidphase mAb (SPRIA) or precipitation of ${ }^{125}$ I- $\alpha$-BT-mAChR (RIA). Sixteen out of 65 anti-tAChR mAbs showed cross-reactivity with mAChR using the SPRIA. Representative examples of the binding of ${ }^{125} \mid-\alpha-B T$ mAChR and $1251-\alpha-B T-t A C h R$ to solid phase mAbs are shown in figure 4 . The cross-reactive mAbs A42, A43, A49, and A60 could also precipitate ${ }^{125}{ }_{1-\alpha \text {-BT- }}$ mAChR using the RIA. All mAbs cross-reactive with mAChR as determined by SPRIA, were also tested for binding to neuromuscular endplates in cryosections of mouse muscle. Twelve of the 16 cross-reactive mAbs bound to endplates (not shown).

\section{In vivo pathogenicity}

To determine the pathogenicity in vivo, mAb A60 was passively transferred to naive $\mathrm{C} 57 \mathrm{bl} / 6$ mice to induce the effector phase of EAMG. Mice injected with $\mathrm{mAb} A 60$ did not show muscle weakness or weight loss at 48 hrs after injection. However, $\mathrm{mAb}$ A60 injected mice showed a mean AChR concentration of $17 \pm 6 \mathrm{pmol} / 100 \mathrm{gr}$ compared to $35 \pm 10 \mathrm{pmol} / 100 \mathrm{gr}$ muscle (mean $\pm S E M$ ) in control mice. 


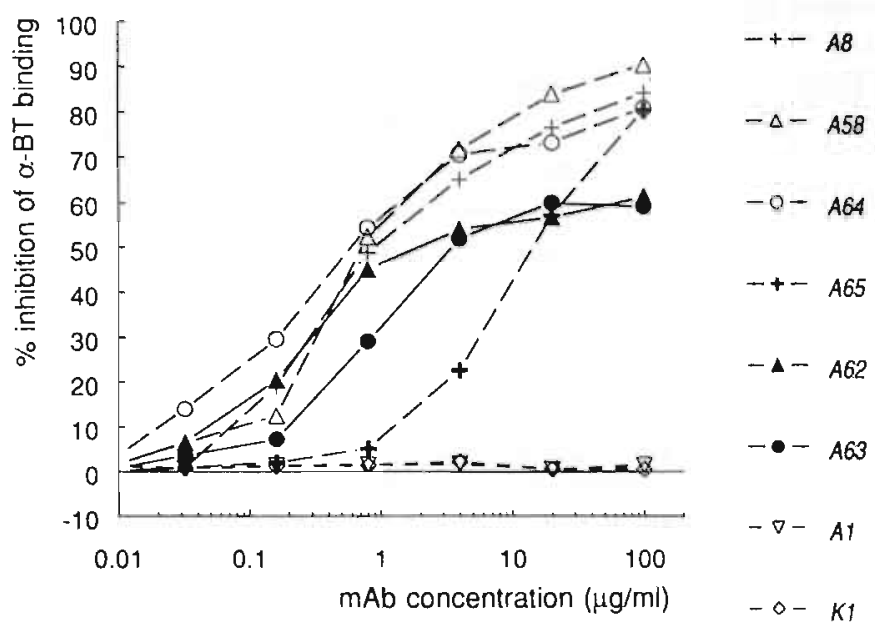

Figure 3: Anti-AChR mAbs directed against the $\alpha$-BT binding site competitively inhibit the binding of ${ }^{125} \mathrm{I}-\alpha$-BT to AChR.

The binding of a limiting concentration of ${ }^{125} / \alpha-\beta T$ to AChR was tested in the presence of putative anti- $\alpha-B T$ binding site antibodies. Results are expressed as percentage inhibition of $\alpha-B T$ binding in the absence of antibody. Anti-MIR MAb A1 and anti-KLH MAb K1 are not capable of inhibiting $\alpha-B T$ binding to AChR.

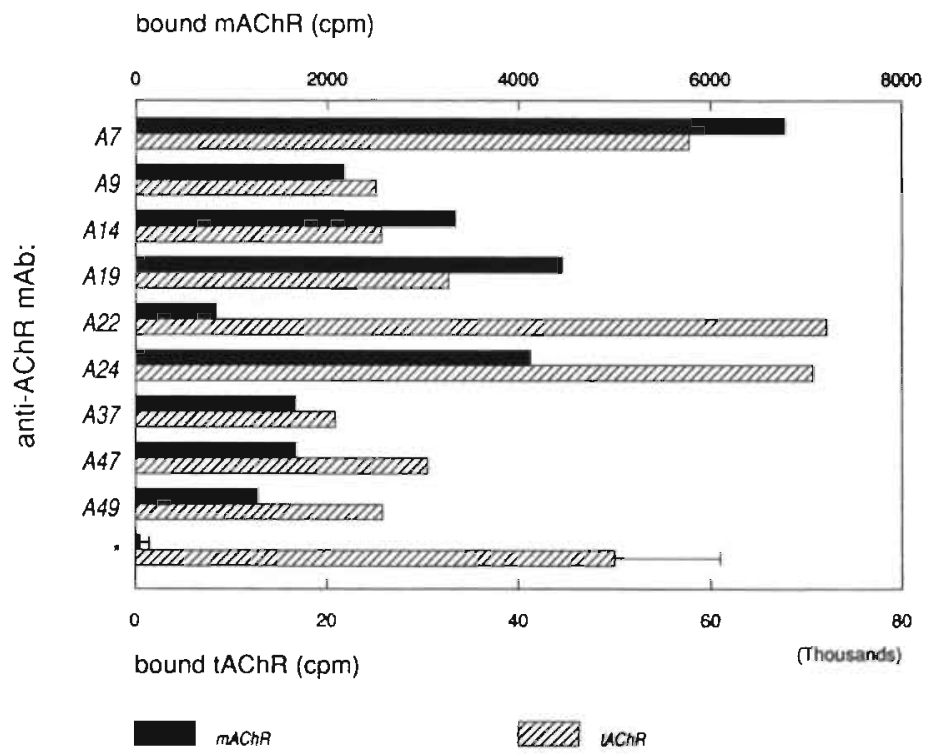

Figure 4: Cross-reactive mAbs detected by solid phase radio immunoassay.

Solid phase anti-AChR mAbs were tested for binding to Torpedo or mouse AChR. The solid bars represent the binding of $M A C h R$ to solid phase $M A b$. The striped bars represent the binding of $t A C h R$ to $\mathrm{mAbs}$.

The asteriks denotes the mean binding of all anti-AChR mAbs considered non cross-reactive. 
Table II: Frequencies of anti-AChR specificities in the clonable repenoire of C57bl/6 and Balb/c mice

\begin{tabular}{|c|c|c|c|c|}
\hline \multirow[b]{2}{*}{ Specificity ${ }^{a}$} & \multicolumn{2}{|c|}{$\mathrm{C} 57 \mathrm{bl} / 6$} & \multicolumn{2}{|c|}{$\mathrm{Balb} / \mathrm{c}$} \\
\hline & $\%$ & $n^{b}$ & $\%$ & $n$ \\
\hline mAChA & 26 & $(308)$ & 14 & (209) \\
\hline $\mathrm{MIR}$ & 20 & (182) & 17 & (151) \\
\hline$\alpha-B T$ & 4 & $(308)$ & 1 & (190) \\
\hline$\alpha 371-378$ & 1 & $(360)$ & 5 & $(330)$ \\
\hline
\end{tabular}

The relative frequencies of clonable $B$ cells from $C 57 \mathrm{~b} / / 6$ and Balb/c mice were determined among initial clones. ${ }^{a} B$ cell clones were isolated which were cross-reactive with $M A C h R$, directed to the MIR, $\alpha-B T$ binding site and an intracellular epitope on the $\alpha$-subunit of AChR ( $\alpha 371-378$ ). The relative frequency of a certain specificity was expressed as the percentage of clones positive of the total number tested. ${ }^{D}$ The total number of tested clones is shown in parenthesis.

\section{Frequencies of antibody specificities from C57bl/6 and $\mathrm{Balb} / \mathrm{c}$ mice}

The relative frequencies of certain specificities obtained from the clonable anti$\mathrm{AChR}$ antibody repertoire of $\mathrm{C} 57 \mathrm{bl} / 6$ and Balb/c mice were compared. The occurance of hybridomas cross-reactive with $\mathrm{MAChR}$ and antibodies against the MIR, $\alpha$-BT binding site, and an intracellular epitope ( $\alpha 371-378$ ) among primary hybridomas was expressed as the percentage of the number of tested hybridomas. Hybridomas cross-reactive with $\mathrm{mAChR}$ were more frequently isolated from $\mathrm{C} 57 \mathrm{bl} / 6$ (26\%) compared to Balb/c mice (14\%) (table II). Hybridomas specific for the MIR and the $\alpha$-BT binding site were found in $20 \%$ and $4 \%$ respectively of the C57bl/6 hybridomas compared to $17 \%$ and $1 \%$ in Balb/c derived hybridomas. However, hybridomas with specificity for an intracellular epitope are more frequently found in Balb/c (5\%) than C57bl/6 (1\%) mice.

\section{Induction of chronic EAMG in $\mathrm{C} 57 \mathrm{bl} / 6$ and $\mathrm{Balb} / \mathrm{c}$ mice}

EAMG was induced in C57bl/6 $(n=8)$ and Balb/c $(n=8)$ mice. Four out of $8 \mathrm{C} 57 \mathrm{bl} / 6$ mice developed rapidly progressive EAMG after the second immunization. Sick animals had typical signs of myasthenia including muscle weakness, tremor, and an inability to adduct the hindlegs. Affected mice showed a rapid loss of weight due to dehydration and usually died within 2 days after onset of the disease (fig. 5A). In contrast, only $1 \mathrm{Balb} / \mathrm{c}$ mouse showed weightloss (fig. $5 \mathrm{C}$ ) and died from severe EAMG. Unaffected C57bl/6 or Balb/c mice showed no weightloss compared to PBS immunized control mice (fig. 5B and 5D). Ali mice immunized with $\mathrm{ACCh}$ developed antibodies against mAChR (fig. $6 \mathrm{~A}$ and $6 \mathrm{~B}$ ). However, no significant difference in mean anti-mAChR antibody titer between $\mathrm{C} 57 \mathrm{~b} / / 6$ and Balb/c mice was seen. A broad range of anti-mAChR titers was found in both sick and healthy mice. The 

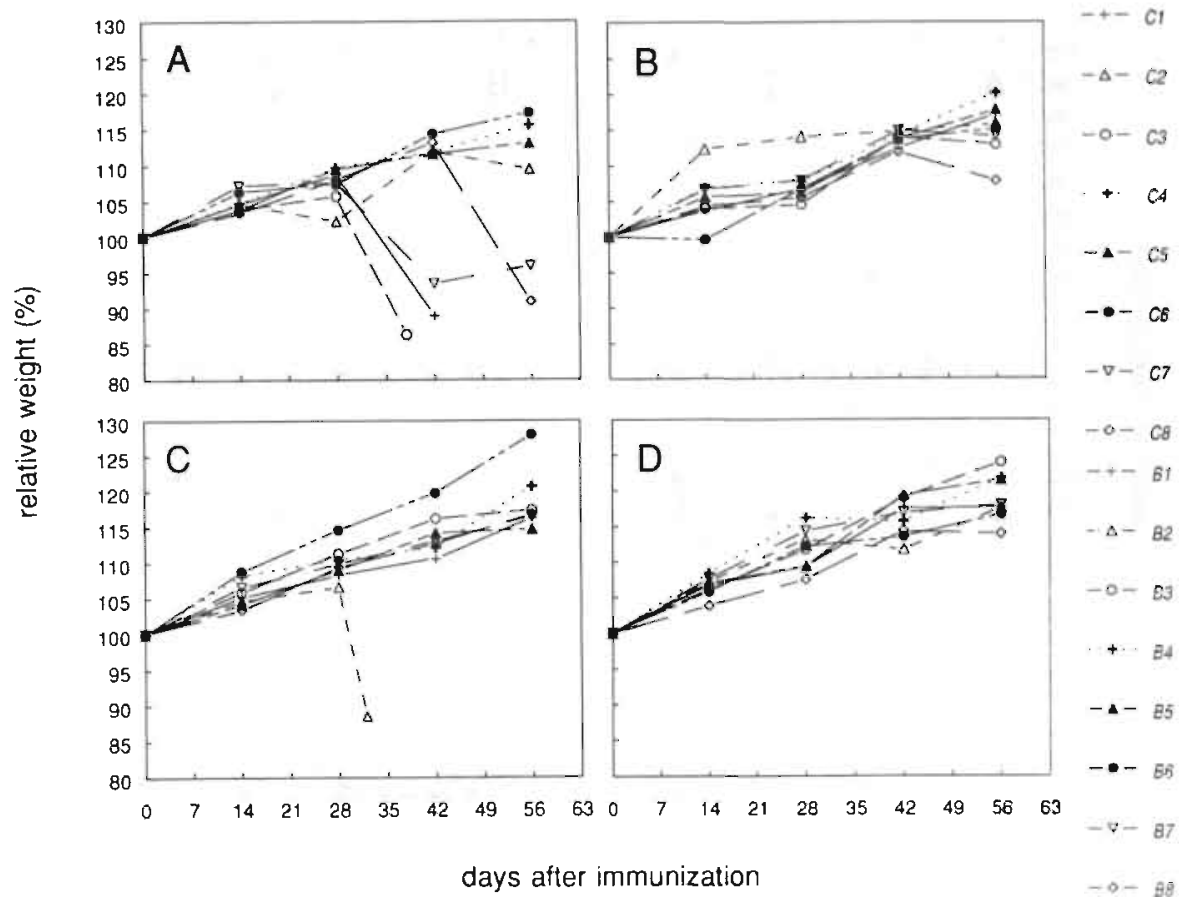

Figure 5: Weightloss as parameter of disease severity.

The weightloss of C57bl/6 and Balb/c mice was monitored at 2 week intervals after immunization with AChR or PBS. Animals with severe EAMG showed a dramatic weight loss due to paralysis. Bodyweight was expressed as percentage of the weight at day 0. C1-C8: C57b//6 $\mathrm{nr}$ 1-8. B1-B8: Balb/C nr 1-8. (A) C57bl/6 mice immunized with AChR. (B) C57bl/6 mice immunized with PBS. (C) Balb/c immunized with AChR. (D) Balb/c mice immunized with PBS.
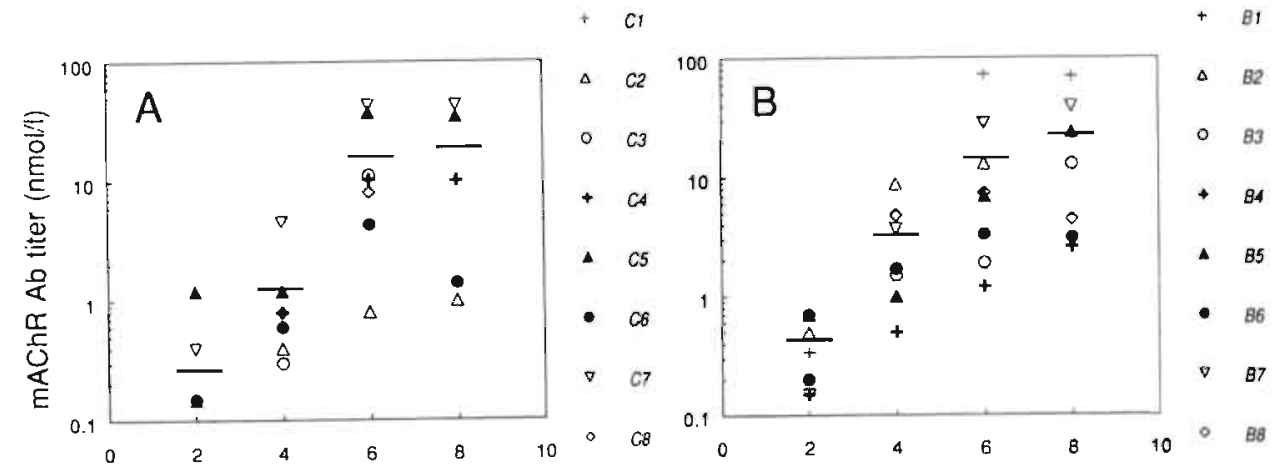

weeks after primary immunization

Figure 6: $\mathrm{C57b} / 6$ and $\mathrm{Balb} / \mathrm{c}$ mice develop similar mean antibody titers against autologous AChR.

The antibody titer against $M A C h R$ was determined at 2 week intervals after immunization with $L A C h R$. The mean anti-mAChR titer is represented by the horizontal bars. (A) The anti-mAChR titers of C57bl/6 mice. C1-C8: C57bl/6 nr 1-8. (B) The anti-mAChR titers of Balb/c mice. B1-B8: Balb/c nr 1-8. 


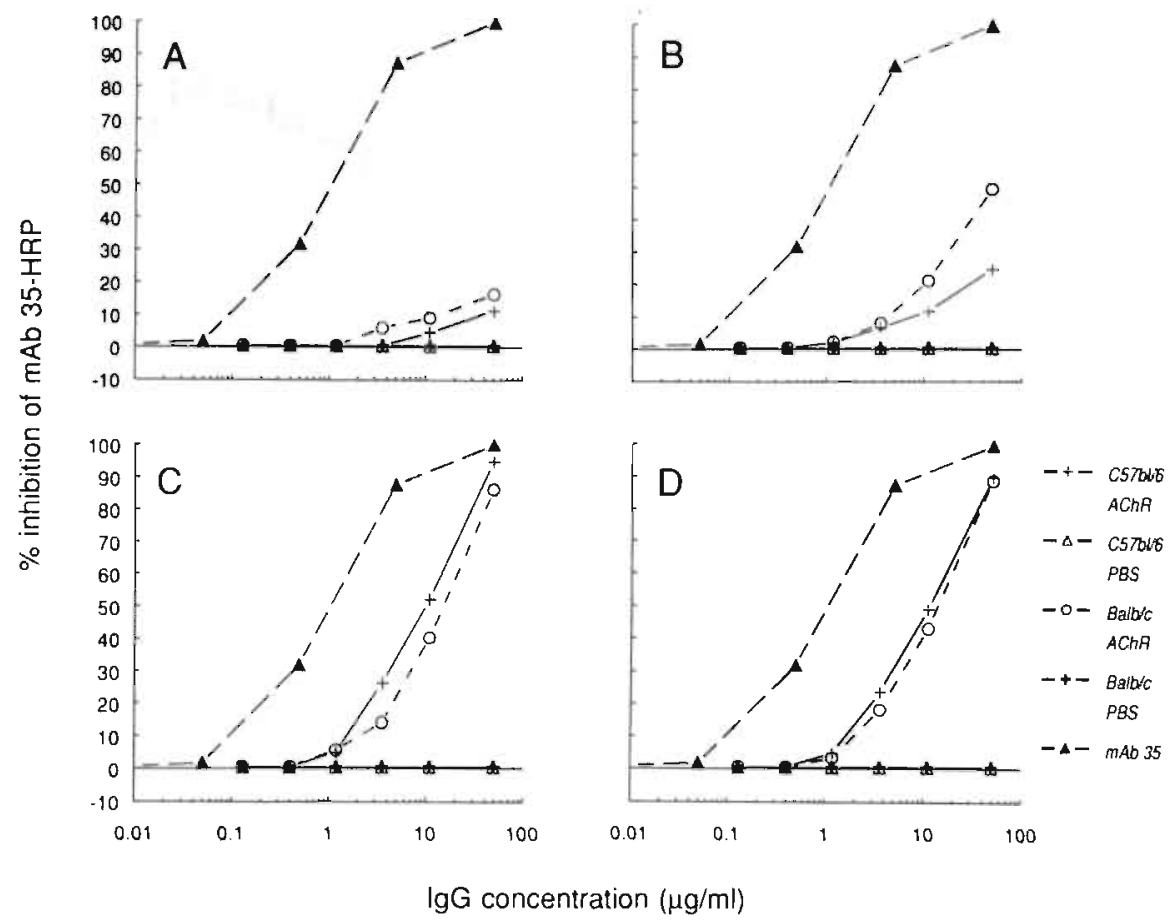

Figure 7: C57bl/6 and Balb/c mice have similar concentrations of antibodies directed against the MIR Antibodies directed against the MIR were detected in IgG from EAMG and control mice by competitive inhibiton of reference anti-MIR mAb 35. (A) Inhibition of MAb 35-HRP 2 weeks after immunization. (B) 4 weeks. (C) 6 weeks. (D) 8 weeks after immunization.

anti-mAChR titer in sick $\mathrm{C} 57 \mathrm{bl} / 6$ ranged from 0.8 to $43 \mathrm{nmol} / \mathrm{l}$ whereas the titer of mice without clinical signs of disease ranged from 1 to $34 \mathrm{nmol} / \mathrm{l}$. No relation between anti-mAChR antibody titer and disease susceptibility could be demonstrated.

\section{Antibody fine specificity in EAMG sera}

The fraction of anti-AChR antibodies directed against the MIR and the $\alpha$-BT binding site were determined in EAMG sera at several points in time after immunization with AChR. Two weeks after the primary immunization less than $0.1 \%$ of total IgG from $\mathrm{C} 57 \mathrm{bl} / 6$ or Balb/c was directed against the MIR (fig. 7A). The fraction of anti-MIR antibodies was increased 4 weeks after immunization. IgG from Balb/c mice showed a stronger inhibition of mAb 35 binding compared to IgG from $\mathrm{C} 57 \mathrm{bl} / 6$ mice (fig. 7B). The higher inhibitory capacity of Balb/c compared to C57bl/6 IgG levelled out after the second immunization (fig. $7 \mathrm{C}$ ). The inhibitory capacity of $\mathrm{C} 57 \mathrm{bl} / 6$ and $\mathrm{Balb} / \mathrm{c} \operatorname{lgG}$ did not further increase 8 weeks after immunization and both mouse strains showed comparable inhibition of mAb 35 binding (fig. 7D). When 


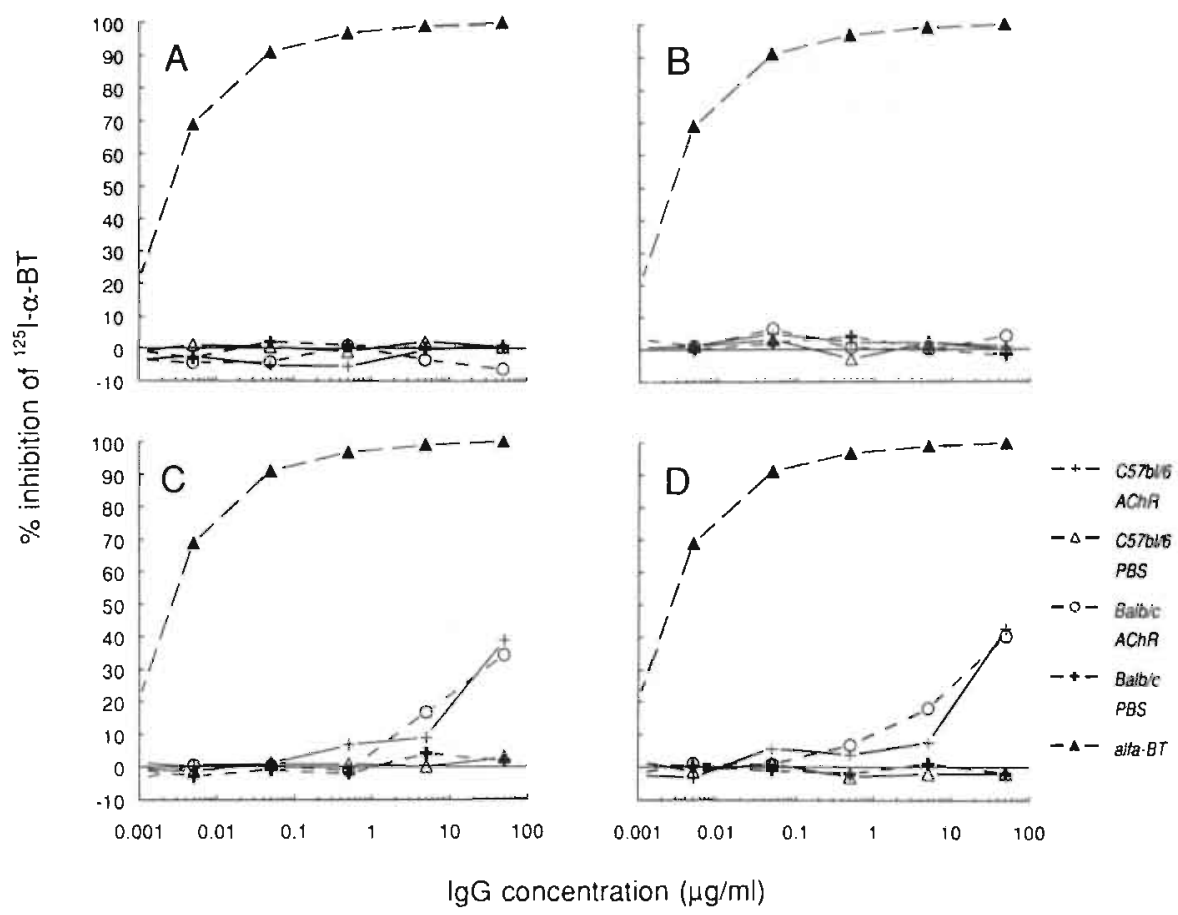

Figure 8: $\mathrm{C} 57 \mathrm{bl} / 6$ and Balb/c mice have similar contrations of anti-site antibodies.

Antibodies directed against the $\alpha$-bungarotoxin binding site were detected in $\lg G$ from EAMG and control mice by competitive inhibition of $\alpha-B T$. (A) Inhibition of $\alpha-B T 2$ weeks after immunization. (B) 4 weeks. (C) 6 weeks. (D) 8 weeks.
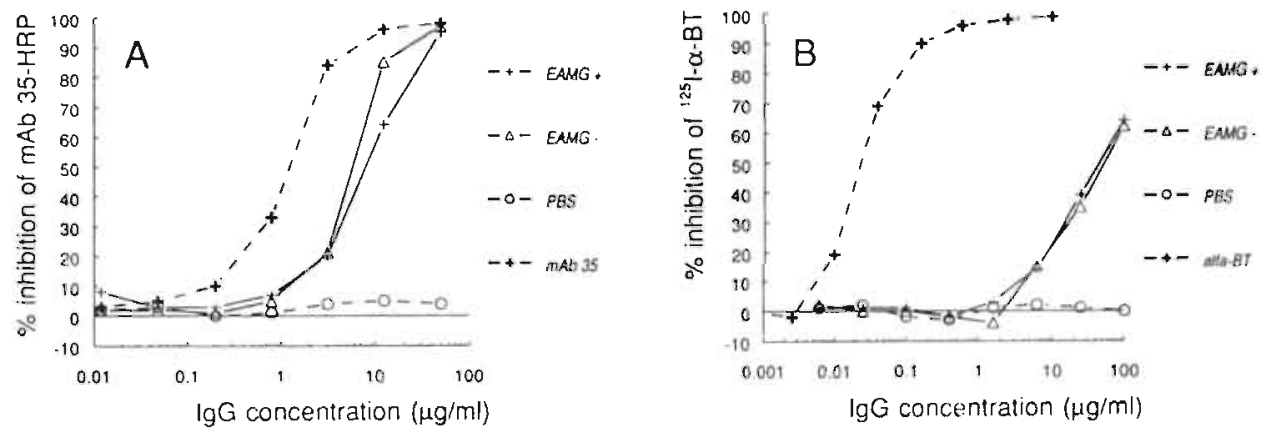

Figure 9: Antibody fine specificity for the MIR or $\alpha$-BT binding site does not differ between paralyzed and non paralyzed C57bl/6 mice.

The fraction of antibodies against the MIR or the $\alpha-B T$ binding site were determined in $\mathrm{IgG}$ from paralyzed (EAMG +) and non-paralyzed (EAMG -) C57bl/6 mice by competitive inhibition 8 weeks after primary immunization. (A) Inhibition of mAb 35 binding. (B) Inhibition of $\alpha-B T$ binding. 
$!_{50}$ concentrations of mAb 35 and EAMG IgG were compared at this point in time, approximately $10 \%$ of total IgG was directed against the MIR in both mouse strains. Antibodies against the $\alpha$-BT binding site were not detected after the first immunization with $A C h R$ (fig. $8 A+B$ ). A similar fraction of total lgG from C57bl/6 or Balb/c mice was directed against the $\alpha$-BT binding site 6 weeks after primary immunization (fig. $8 \mathrm{C}$ ), which was not increased at 8 weeks (fig. 8D). At 8 weeks less than $0.5 \%$ of total EAMG IgG was directed against the $\alpha$-BT binding site.

When antibody fine specificities were compared between paralyzed and nonparalyzed $\mathrm{C} 57 \mathrm{bl} / 6$ mice, no differences in the fractions of antibodies to the MIR or $\alpha-B$ T binding site were observed (fig. 9A+B).

\section{DISCUSSION}

Monoclonal antibodies against AChR were obtained from EAMG high susceptible $\mathrm{C} 57 \mathrm{bl} / 6$ and low susceptible Balb/c mice. Antibodies directed to several epitopes including the MIR and $\alpha$-BT binding site were isolated from both $\mathrm{C} 57 \mathrm{bl} / 6$ and $\mathrm{Balb} / \mathrm{c}$ mice. Among mAbs that bound AChR in membrane vesicles, several were directed against the MIR as determined by competitive inhibition with reference anti-MIR mAb 35 (26). Among mAbs that bound solubilized AChR but no AChR incorporated in vesicles, several were competitive with $\mathrm{mAb} 155$ (5) against an intracellular epitope ( $\alpha 371-378$ ) but none of these mAbs were competitive with mAb 35 against the extracellularly located MIR. These results are in agreement with electronmicroscopic imaging of gold labeled anti-AChR mAbs against extra- and intracellular epitopes which were demonstrated to bind to the exterior or interior surface of these AChR vesicles (27).

A major part of anti-AChR antibodies in MG and rats immunized with intact AChR are directed against the MIR localized on the $\alpha$-subunit at residues $67-76(4,23)$. Anti-MIR mAbs are very potent in accelerating AChR degradation by antigenic modulation (28) and are able to induce EAMG in animals by passive transfer (29). Mouse mAbs against the MIR were distinguished from mAbs to other extracellular epitopes on AChR by competitive inhibition with reference anti-MIR mAb 35. Seventeen mAbs were competitive with anti-MIR mAb 35 and varying amounts of these mAbs were needed to inhibit mAb 35 for $50 \%$, indicating that these mAbs show variing affinities for the MIR or recognize epitopes partially overlapping the MIR. MAbs with fine specificity for epitopes separated by only seven residues can be distiguished using this competitive inhibition technique (21). Similarly, mouse mAbs against human AChR were also found to inhibit mAb 35 and are directed against two antigenic regions overlapping the MIR (24).

Six mAbs were isolated that competitively inhibit the binding of $\alpha$-BT to the AChR The $\alpha$-BT binding site, including the cholinergic binding site, is located on the $\alpha$-subunit ( $\alpha 189-195)$ distinct from the MIR (31). Four anti- $\alpha$-BT binding site mAbs were able to inhibit $\alpha-B T$ binding almost completely whereas two mAbs inhibited $\alpha$-BT binding to a maximum of $50 \%$. MAbs completely inhibiting $\alpha$-BT are probably directed to epitopes similar for both $\alpha$-BT binding sites on each AChR molecule, whereas mAbs partially inhibiting $\alpha$-BT are directed to epitopes unique to each of the two binding sites $(31,32,33)$. The mAbs A62 and A63 inhibited $\alpha$-BT to a 
maximum of $50 \%$ and are probably directed to the same $\alpha$-BT binding site because when mAbs were combined they still inhibited $\alpha$-BT binding no more than $50 \%$. Furthermore, the crossreaction of anti-AChR mAbs with autologous AChR was determined since mAbs reacting with $M A C h R$ could be pathogenic in vivo. Sixteen out of 65 mAbs were cross-reactive with mAChR as determined by solid- or liquid phase radio immunoassay or binding to the motor endplates in muscle sections. Four of these mAbs precipitated mAChR using the standard liquid phase precipitation radio immunoassay (19). Precipitation of some mAbs may be less efficient because they were not recognized by the polyclonal goat-anti-mouse lgG used to precipitate mAb-AChR complexes.

Differences in disease susceptibility between C57b//6 and Balb/c mice could reside from differences in the available anti-AChR antibody repertoire. Therefore, the frequency of different antibody specificities in the clonable B-cell repertoire was compared between $\mathrm{C} 57 \mathrm{bl} / 6$ and Balb/c mice. Among initial hybridomas isolated from C57bl/6 mice, $26 \%$ was cross-reactive with mAChR compared to $14 \% \mathrm{Balb} / \mathrm{C}$ mice. Autoreactive clones may therefore be more abundant in susceptible mice. Furthermore, the frequency of clones against the MIR and $\alpha$-BT binding site were higher in $\mathrm{C} 57 \mathrm{bl} / 6$ compared to Balb/c mice whereas clones against an intracellular epitope were more frequently found in Balb/C mice. It was further investigated whether these differences in the frequency of available antibody specificities could also be demonstrated in the polyclonal anti-AChR response after induction of EAMG by immunization with tAChR.

$\mathrm{C} 57 \mathrm{bl} / 6$ and $\mathrm{Balb} / \mathrm{c}$ mice immunized with $\mathrm{tAChR}$ developed a similar mean serum anti-mAChR antibody titer which did not reflect the observed difference in the frequency of autoreactive hybridomas between C57bl/6 and Balb/c mice. The frequency of autoreactive hybridomas in vitro may not be representative for the in vivo activation of autoreactive clones.

Although the mean serum anti-mAChR antibody titers for each mouse strain were similar, large differences in titer were found between individual mice. Furthermore, the anti-mAChR titer did not correlate with appearance of clinical signs. The high variability in anti-mAChR antibody titer and absence of an obvious correlation between anti-mAChR antibody concentrations and development of EAMG is also found by other investigators $(14,15,34,35)$ and mirrors the lack of correlation between serum anti-AChR antibody concentration and the clinical state in MG (36, 37). This can be explained by the fact that part of the antibodies cross-reactive with mAChR may not be detected in the sera due to in vivo binding to the AChR. Moreover, antibodies against the $\alpha$-BT binding site are not detected in the conventional RIA used for anti-AChR antibody determination. Furthermore, only a small part of total anti-AChR antibody pool may be relevant for the pathogenesis of the disease, and the major fraction of the detected anti-AChR antibody pool may consist of non-pathogenic antibodies which confuse the correlation between anti-AChR antibody titer and disease severity.

Thus, the absolute amount of antibody does not determine disease susceptibility. However, differences in antibody fine specificity may determine the outcome of the disease. Antibodies against the MIR of the AChR were demonstrated in pooled IgG from EAMG mice by competitive inhibition with reference anti-MIR mAb 35. After 
secondary immunization approximately $10 \%$ of total IgG was directed against the MIR in both mouse strains. The observed difference in frequency of clonable anti-MIR B-cells was not observed in the polyclonal anti-AChR response. No difference in the fraction of serum anti-MIR antibodies was found that could be related to susceptibility for EAMG. Antibodies against the MIR constitute a substantial part of the anti-AChR antibodies in $M G(23,24)$. However, no relation was found between antibody specificity and clinical state of the patient $(23,24)$. The fraction of antibodies against the MIR in MG patients remained stable even after decline of the total anti-AChR antibody titer and clinical improvement (24).

Similar fractions of total IgG were found to be directed against the $\alpha$-BT binding site in $\mathrm{C} 57 \mathrm{bl} / 6$ and $\mathrm{Balb} / \mathrm{C}$ mice and therefore no relation was found between disease susceptibility and the fraction of site specific antibodies. Less than $0.5 \%$ of the total EAMG IgG was directed to the $\alpha$-BT binding site. Antibodies against the cholinergic binding site probably play a minor role in EAMG (38). Furthermore, the concentration of anti-site antibodies did not correlate with the severity of $M G(39,40)$.

Taken together, these results indicate that strain specific differences in disease susceptibility in murine EAMG are not related to differences in the overall concentration of antibodies against the MIR or $\alpha$-BT binding site. Moreover, no differences in the fractions of antibodies against the MIR or $\alpha$-BT binding site were found between paralyzed and non-paralyzed $\mathrm{C} 57 \mathrm{bl} / 6$ mice. Our results are in agreement with a report of Berman and Patrick, in which accelerated AChR degradation by sera from paralyzed and nonparalyzed mice, was shown to be indistinguishable (14). However, other antigenic fine specificities which consitute only a minor part of the total anti-AChR antibody pool could be important in causing the disease. It was demonstrated that transfer of pooled EAMG sera from susceptible C57b//6J mice to naive $\mathrm{C} 3 \mathrm{H} / \mathrm{HeJ}$ or $\mathrm{C} 57 \mathrm{bl} / 6 \mathrm{~J}$ mice induced muscle weakness, whereas transfer of resistant $\mathrm{C} 3 \mathrm{H} / \mathrm{HeJ}$ EAMG sera were unable to induce weakness in both mice strains (41). Similar results were obtained with susceptible Lewis vs. resistant Wistar Furth rats $(45)$. Antibodies that impair the ion channel $(12,42,43)$ function of AChR may contribute to impairment of the neuromuscular signal transmission combined with AChR loss by complement mediated destruction and antigenic modulation. Probably multiple immunological (15) as well as physiological factors (44) determine susceptibility for EAMG.

Monoclonal anti-AChR antibodies from both mouse strains will be used to investigate possible differences in the genetic diversity of anti-AChR antibodies that could be related to disease susceptibility. 


\section{REFERENCES}

1 Lindstrom J, Shelton D, Fujii Y. (1988). Myasthenia gravis. Adv. Immunol. 42:233-284

2 Raftery M, Hunkappilar M, Strader C, Hood L. (1980). Acetylcholine receptor: complex of homologous subunits. Science 208:1454-1457

3 Tzartos SJ, and Remoundos MS. (1990). Fine localization of the major $\alpha$-bungarotoxin site to residues $\alpha 189-195$ of Torpedo californica acetylcholine receptor. Residues 189 . 190 and 195 are indispensable for binding. J. Biol. Chem. 265:21462-21467

4 Tzartos SJ, Lindstrom JM. (1980). Monoclonal antibodies used to probe acetylcholine receptor structure: localization of the main immunogenic region and detection of similarities between subunits. Proc. Natl. Acad. Sci. USA. 77:755-759

5 Tzartos SJ, Kokla A, Waigrave S, Conti-Tronconi B. (1988). Localization of the main immunogenic region of human muscle acetylcholine receptor to residues $67-76$ of the $\alpha$-subunit. Proc. Natl. Acad. Sci. USA. 85:2899-2903

6 Engel AG, Lambert EH, Howard FM. (1977). Immune complexes (IgG and C3) at the motor endplate in myasthenia gravis. Ultrastructural and light microscopic localization and electrophysiologic correlations. Mayo Clin. Proc. 52:267-280

7 Lennon VA, Seybold ME, Lindstrom JM, Cochrane C, Ulevitch R. (1978). Role of complement in the pathogenesis of experimental autoimmune myasthenia gravis. J. Exp. Med. 147:973-983

8 Kao I, Drachman DB. (1977). Myasthenic immunoglobulin accelerates acetylcholine receptor degradation. Science 196:527-529

9 Heineman S, Bevan S, Kullberg R, Lindstrom J, Rice J. (1977) Modulation of acetylcholine receptor by antibody against the receptor. Proc. Natl. Acad. Sci. USA. 74:3090-3094.

10 Almon RR, Andrew CG, Appel SH. (1974). Serum globulin in myasthenia gravis: Inhibition of $\alpha$-bungarotoxin binding to acetylcholine receptors. Science 186:55-57

11 Karlin A, Holtzman E, Valderrama R, Damle V, Hsu K, Reyes F. (1978). Binding of antibodies to acetylcholine receptors in Electrophorus and Torpedo electroplax membranes. J. Cell. Biol. 76:577-592

12 Lang B, Richardson G, Rees J. (1988). Plasma from myasthenia gravis patients reduces acetylcholine receptor agonist-induced $\mathrm{Na}+$ flux into TE671 cell line. J. Neuroimmunol. 19:141-148

13 Fuchs S, Nevo D, Tarrab-Hazdai R. (1976). Strain differences in the autoimmune response of mice to the acetylcholine receptors. Nature 263:329-330

14 Berman PW, Patrick J. (1980). Experimental myasthenia gravis. A murine system. J. Exp. Med. 151:204-223

15 Christados P. (1989). Immunogenetics of experimental autoimmune myasthenia gravis. Crit. Rev. Immunol. 9:247-279.

16 Biesecker G, Koffler D. (1988). Resistance to experimental autoimmune myastenia gravis in genetically inbred rats. Association with decreased amounts of in situ acetylcholine receptor-antibody complexes. J. Immunol. 140:3406-3410

17 Lindstrom J, Anholt R, Einarson B, Engel A, Osame M, Montal M. (1980). Purification of acetylcholine receptors, reconstitution into lipid vesicles, and study of agonist-induced cation channel regulation. J. Biol. Chem. 255:8340-8350

18 Kohler G, Milstein C. (1975). Continuous cultures of fused cells secreting antibody of predefined specificity. Nature 256:495-497

19 Lindstrom MJ, Einarson BL, Lennon VA, Seybold ME. (1976). Pathological mechanisms in experimental autoimmune myasthenia gravis. I Immunogenicity of syngeneic acetylcholine receptor and quantitative extraction of receptor and antibody-receptor complexes from muscle of rats with experimental autoimmune myasthenia gravis. J. Exp. Med. 144:726-738 
20 Sargent PB, Hedges BE, Tsavaler L, Clemmons L, Tzartos S, Lindstrom JM. (1984). Structure and transmembrane nature of acetylcholine receptor in amphibian skeletal muscle as revealed by cross-reacting monoclonal antibodies. J. Cell Biol. 98:609-618

21 Kordossi A, Tzartos SJ, (1991). Conformation of cytoplasmic segments of acetylcholine receptor $\alpha$ and $\beta$ subunits probed by monoclonal antibodies. Sensitivity of the antibody competition approach. EMBO J. 6:1605-1610

22 De Baets MH, Theunissen R, Kok K, De Vijlder JJM, van Breda Vriesman PJC. (1987) Monoclonal antibodies to human thyroglobulin as probes for thyroglobulin structure. Endocrinology 120:1104-1111

23 Tzartos SJ, Seybold ME, Lindstrom JM. (1982). Specificities of antibodies to acetylcholine receptors in sera from myasthenia gravis patients measured by monoclonal antibodies. Proc. Natl. Acad. Sci. USA. 79:188-192

24 Whiting PJ, Vincent A, Newsom-Davis J. (1986). Monoclonal antihuman acetylcholine receptor antibodies used to analyze antibody specificities and response to treatment. Neurology 36:612-617

25 Vincent A, Whiting PJ, Schluep M, Heidenreich F, Lang B, Roberts A, Wilcox N, Newsom-Davis J. (1987). Antibody heterogeneity and specificity in myasthenia gravis. Ann. N. Y. Acad. Sci. 505:106-120

26 Tzartos SJ, Rand DE, Einarson BE, Lindstrom JM. (1981). Mapping of surface structures of electrophorus acetylcholine receptors using monoclonal antibodies. J. Biol. Chem. 256:8635-8645

27 Ratnam M, Le Nguyen D, Rivier J Sargent P, Lindstrom J. (1986). Transmembrane topography of nicotinic acetylcholine receptor: Immunochemical tests contradict theoretical predictions based on hydrophobicity profiles. Biochemistry $25: 2633-2643$

28 Tzartos SJ, Sophianos D, Efthimiadis A. (1985). Role of the main immunogenic region of the acetylcholine receptor in myasthenia gravis. An Fab monoclonal antibody protects against antigenic modulation by human sera. J. Immunol. 134:2343-2349

29 Tzartos SJ, Hochschwender S, Vasquez P, Lindstrom J. (1987). Passive transfer of experimental autoimmune myasthenia gravis by monoclonal antibodies to the main immunogenic region of the acetylcholine receptor. J. Neuroimmunol. 15:185-194

30 Tzartos SJ, Remoundos MS. (1990). Fine localization of the major $\alpha$-bungarotoxin site to residues $\alpha 189-195$ of Torpedo acetylcholine receptor. Residues $189-190$ and 195 are indispensable for binding. J. Biol. Chem. 265:21462-21467

31 Watters D, Maelicke A. (1983). Organization of ligand binding sites at the acetylcholine receptor: a study with monoclonal antibodies. Biochemistry 22:1811-1819

32 Whiting P, Vincent A, Newsom-Davis J. (1985). Monoclonal antibodies to Torpedo acetylcholine receptor. Characterization of antigenic determinants within the cholinergic binding site. Eur. J. Biochem. 150:533-539

33 Dowding AJ, Hall ZW. (1987). Monoclonal antibodies specific for each of the two toxin-binding sites of Torpedo acetylcholine receptor. Biochemistry 26:6372-638135

34 Hohlfeld R, Sterz R, Kalies I, Wekerle H, Peper K. (1983). Experimental myasthenia: lack of correlation between the autoantibody titer and the reduction of acetylcholine-controlled tonic channels measured at functional endplates. Muscle and Nerve 6:160-163

35 Christadoss P, Lindstrom J, Munro S, Tadal N. (1985). Muscle acetylcholine receptor loss in murine experimental autoimmune myasthenia gravis: correlated with cellular, humoral and clinical responses. J. Neuroimmunol. 8:29-41

36 Lindstrom JM, Seybold ME, Lennon VA, Whittingham S, Duane DD. (1976). Antibody to acetylcholine receptor in myasthenia gravis: prevalence, clinical correlations, and diagnostic value. Neurology 26:1054-1059

37 Tindal RSA. (1981). Humoral immunity in myasthenia gravis: clinical correlations of anti-receptor antibody avidity and titer. Ann. N. Y. Acad. Sci. 377:316-331 
38 Claudio T, Raftery MA. (1980). Inhibition of $\alpha$-bungarotoxin binding to acetylcholine receptors by antisera from animals with experimental autoimmune myasthenia gravis. $\mathrm{J}$. Supramolucular. Struct. 14:267-279

39 Pachner AR. (1989). Anti-acetylcholine receptor antibodies block bungarotoxin binding to native human acetylcholine receptor on the surface of TE671 cells. Neurology 39:1057-1061

40 Vernet der Garabedian B, Bach JF, Morel E. (1987). Heterogeneity of antibodies directed against the $\alpha$-bungarotoxin binding site on human acetylcholine receptor and the severity of myasthenia gravis. J. Neuroimmunol. 12:65-74

41 Marzo AL, Garlepp MJ, Schon-Hegard M, Dawkins RL. (1986). Susceptibility to murine experimental autoallergic myasthenia gravis: the role of antibody specificity. Clin. Exp. Immunol. 64:101-106

42 Donnelly A, Mihovilovic M, Gonzalez JM, Ferragut JA, Richman D, Martinez-Carrion M. (1984). Noncholinergic site-directed monoclonal antibody can impair agonist-induced ion flux in Torpedo californica acetylcholine receptor. Proc. Natl. Acad. Sci. USA. 81:7999-8003

43 Verschuuren JJGM, Graus YMF, Theunissen ROM, Yamamoto T, Vincent A, van Breda Vriesman PJC, De Baets MH. (1992). Role of acetylcholine receptor antibody complexes in muscle in experimental autoimmune myasthenia gravis. J. Neuroimmunol. 36:117-125.

44 Graus YMF, Verschuuren JJGM, Spaans F, Jennekens F, van Breda Vriesman PJC, De Baets MH. (1992). Age related resistance to experimental autoimmune myasthenia gravis in rats. submitted for publication

45 Zoda T, Yeh T-M, Krolick KA. (1991). Clonotypic analysis of anti-acetylcholine receptor antibodies from experimental autoimmune myasthenia gravis-sensitive Lewis rats and experimental autoimmune myasthenia gravis resistant Wistar Furth rats. J. Immunol. $146: 663-670$ 


\section{Chapter 5}

$V_{H}$ gene family utilization of anti-acetylcholine receptor: Antibodies in murine experimental autoimmune myasthenia gravis

Yvo M.F. Graus, Jan J.G.M. Verschuuren, Nico A. Bos, Peter J.C. vanı Breda Vriesman, and Marc H. De Baets. 


\section{$\mathrm{V}_{\mathrm{H}}$ gene family utilization of anti-acetylcholine receptor: Antibodies in murine experimental autoimmune myasthenia gravis}

\section{ABSTRACT}

In the mouse model for experimental autoimmune myasthenia gravis (EAMG) we determined the utilization of immunoglobulin heavy chain $\left(V_{H}\right)$ gene families by anti-acetylcholine receptor (AChR) mAbs obtained from two mouse strains differing in their susceptibility for induction of EAMG by immunization with Torpedo AChR. Previously, a preferential usage of D-proximal $V_{H}$ gene families in autoimmune diseases was suggested. To investigate a possible bias in $\mathrm{V}_{\mathrm{H}}$ gene family usage in the EAMG model we determined the $V_{H}$ gene family usage of 65 anti-AChR $\mathrm{mAbs}$ and 20 anti-KLH mAbs isolated from high susceptible $\mathrm{C} 57 \mathrm{bl} / 6\left(\mathrm{H}-2^{\mathrm{d}}, \mathrm{IgH}^{\mathrm{b}}\right)$ and low susceptible Balb/c $\left(\mathrm{H}-2^{\mathrm{b}}, \operatorname{lgH}^{\mathrm{a}}\right)$ mice by RNA slot-blot analysis, using probes for nine $V_{H}$ gene families. Anti-AChR mAbs were found to be encoded by $V_{H}$ genes from at least 6 different families. The $V_{H}$ gene family usage of anti-AChR mAbs approached a stochastic distribution over the different $V_{H}$ gene families, however significant deviations from this distribution were found in the $J 606$ and Vgam3.8 families. The Vgam3.8 family was markedly overrepresented in mAbs directed to the $\alpha$-bungarotoxin binding site. No correlation was found between $V_{H}$ gene family usage and antibody specificity for the main immunogenic region of the AChR. Expression of cross-reactive idiotopes by anti-AChR mAbs was irrespective of the $\mathrm{VH}_{\mathrm{H}}$ gene family usage. Furthermore, strain dependent differences in susceptibility for EAMG are not reflected in an aberrant $V_{H}$ gene family usage.

These findings indicate that anti-AChR mAbs can be encoded by $\mathrm{V}_{H}$ genes from most of the $V_{H}$ gene families, and no bias in $V_{H}$ gene family usage towards D-proximal $\mathrm{VH}_{\mathrm{H}}$ gene families could be demonstrated. 


\section{INTRODUCTION}

Myasthenia gravis is an antibody mediated autoimmune disease in which antibodies to the AChR impair the neuromuscular transmission (1). The antibody dependence of MG was demonstrated by passive transfer of anti-AChR antibodies from myasthenic patients (2) or animals with EAMG $(3,4,5)$. The clinical features of $M G$ can be induced in experimental animals by immunization with AChR from Torpedo californica, eliciting antibodies that cross-react with autologous AChR. Antibodies directed to the AChR play a central role in the pathogenesis of MG and therefore insight in the genetic origin of these autoantibodies could give information about the pathogenic mechanisms of the disease. Many studies have examined the diversity of $V_{H}$ genes used in autoantibodies derived from normal mice (6-10), from autoimmune prone animals (11-24) and experimentally induced autoantibodies (25-32).

The $V_{H}$ genes in the mouse are currently classified into $12 V_{H}$ gene families comprising $V_{H}$ genes with more than $80 \%$ nucleotide sequence similarity (33-37). The $V_{H}$ gene families are generally grouped in clusters which are localized on chromosome 12 adjacent to the D-region $(38,39)$.

Some of the studies analyzing the $V_{H}$ gene family utilization of autoantibody producing hybridomas showed a preferential usage of the D-proximal Q52 and PC7183 families $(27-29,40)$, suggesting a biased utilization of D-proximal located $V_{H}$ gene families in autoantibodies. Other reports concerning the $V_{H}$ gene family usage in autoantibodies are in favor of a random $V_{H}$ gene family utilization $(7,17$, $21,22,32)$, which is proportional to the size of the $V_{H}$ gene family (41).

D-proximal $V_{H}$ gene families are preferentially used in the fetal and neonatal $B$ cell repertoires (42), before antigenic selection can play a role (6). Furthermore, a high frequency of multi- and autoreactive hybridomas was found among this early $B$ cell repertoire $(43,44)$. Autoantibodies could therefore arise from this multireactive repertoire and display a biased $V_{H}$ gene family usage. To investigate a possible preferential usage of $V_{H}$ genes in EAMG we determined the $V_{H}$ gene family utilization of anti-AChR mAbs obtained from $\mathrm{C} 57 \mathrm{bl} / 6$ and Balb/c mice immunized with AChR from Torpedo californica. It has been demonstrated that inbred mice strains differ in their susceptibility for the induction of EAMG; C57bl/6 mice $\left(\mathrm{H}-2^{d}\right.$, $\left.\mathrm{lg} \mathrm{H}^{\mathrm{b}}\right)$ are susceptible, whereas Balb/c mice $\left(\mathrm{H}-2^{\mathrm{b}}, \mathrm{lg} \mathrm{H}^{\mathrm{a}}\right)$ are relatively resistant to the induction of disease $(45,46)$. In this study, the relationship between $V_{H}$ gene family usage of anti-AChR mAbs and strain specific differences in disease susceptibility was analyzed. Furthermore, mAbs directed to the MIR (47) and the $\alpha$-BT binding site (48) were selected and the $V_{H}$ gene familiy usage was correlated with specificity for these well defined epitopes on AChR.

In a previous report we showed that rat anti-AChR mAbs express a cross-reactive idiotype (CRI) (49). In this report we extended this study to mouse anti-AChR mAbs and investigated if expression of $C R I$ was correlated to a particular $V_{H}$ gene family usage.

It could be demonstrated that anti-AChR mAbs were encoded by $V_{H}$ genes from at least 6 different families and the $V_{H}$ gene family usage approached a stochastic distribution over the different $V_{H}$ gene families, except for the J606 and Vgam3.8 
families which were significantly under- and overrepresented respectively. The Vgam3.8 family was overrepresented in anti- $\alpha$-BT binding site mAbs, but expression of $C R I$ was found to be irrespective of $V_{H}$ gene family usage. Differences in disease susceptibility could not be explained by a deviant $V_{H}$ gene family usage, except for anti- $\alpha$-BT binding site mAbs obtained from C57bl/6 mice, which showed a overrepresentation of the Vgam3.8 family.

\section{MATERIAL AND METHODS}

\section{Anti-AChR monoclonal antibodies}

Monoclonal antibodies against Torpedo AChR were isolated from C57bl/6 and $\mathrm{Balb} / \mathrm{c}$ mice. Induction and characterization of anti-AChR mAbs are previously described in chapter 2.

\section{Analysis of cross-reactive idiotopes on mouse anti-AChR mAbs}

A cross-reactive idiotype (CRI) specific for anti-AChR mAbs was defined by polyclonal affinity purified anti-idiotype antibodies (anti-Id) against rat mAbs as previously described (49). A polyclonal anti-ld against anti-thyroglobulin mAb 62 (50) was used as control anti-ld. Briefly, purified anti-AChR and control mAbs were coated to ELISA plates $(5 \mu \mathrm{g} / \mathrm{ml})$ and incubated with anti-1d6, 35 and 62 antibody $(10 \mu \mathrm{g} / \mathrm{ml})$. Bound anti-ld antibodies were detected by HRP conjugated swine-antirabbit Ig antibodies.

\section{Preparation of RNA}

Total cytoplasmic RNA of $10^{8}$ viable hybridoma cells was prepared according to Maniatis et al (51), using $20 \mathrm{mM}$ vanadyl ribonuclase inhibitor complex (New England Biolabs, Beverly MA, USA).

The concentration of RNA preparations was determined using a DNA dipstick kit (Invitrogen, San Diego CA, USA). The RNA samples were diluted in $20 \times$ SSC to a range of $1,0.5,0.25 \mu \mathrm{g}$ and immobilized on B85 nitrocellulose filters (Scheicher and Schuell, 's-Hertogenbosch. The Netherlands) using a Minifold II slot-blot manifold. Nitrocellulose filters were air dried and baked at $80^{\circ} \mathrm{C}$ for 2 hours.

\section{Hybridization and washing conditions}

Filters were prehybridized for 4 hours at $42{ }^{\circ} \mathrm{C}$ in hybridization mix containing $50 \%$ $\mathrm{w} / \mathrm{v}$ formamide, $10 \% \mathrm{w} / \mathrm{v}$ dextran sulfate, $1 \mathrm{M} \mathrm{NaCl}, 50 \mathrm{mM}$ Tris- $\mathrm{HCl}(\mathrm{pH}=8.0) 10 \%$ v/v Denhardt's solution containing $2 \%$ w/v Ficoll, $2 \%$ w/v BSA, $2 \%$ w/v polyvinylpyrrolidone and $100 \mu \mathrm{g} / \mathrm{ml}$ denatured salmon sperm DNA. Filters were hybridized with ${ }^{32} \mathrm{P}$-labeled DNA probes (approximately $5 \times 10^{6} \mathrm{cpm} / \mathrm{ml}$ ) in hybridization mix for 16 hours at $42^{\circ} \mathrm{C}$ and subsequently washed in $3 \times$ SSC, $0.1 \% \mathrm{w} / \mathrm{V}$ SDS, and twice in $1 \times$ SSC, $0.1 \%$ w/v SDS at $42^{\circ} \mathrm{C}$. Autoradiography was performed by a 24-72 hrs exposure to Kodak XAR-5 X-ray film using an intensifier screen (Du Pont) at $-70^{\circ} \mathrm{C}$.

\section{DNA probes}

DNA probes representative for the mouse $V_{H}$ gene families J558, PC7183, Q52, J606, 3660, S107 and X24 used in this study are previously described (6). The $V_{H}$ 
23-9 probe $\left(V_{H} 3609\right)$ is a 500 bp Bam HI-Pst I fragment containing a $V_{H}$ sequence belonging to the 3609 family. The Vgam3.8 probe contains a 550 bp Pst 1-Eco R1 fragment of the sequence of Vgam3.8. These probes were gifts from Drs. D. Holmberg, J. Kearney, F. Alt, and D. Schulze.

\section{Statistical methods}

$\chi^{2}$ test was applied to compare differences in $V_{H}$ gene family utilization of mAbs or subgroups of mAbs. For comparison of subgroups of anti-AChR mAbs, the $V_{H}$ gene families were devided into three groups according to their location relative to the D-region (39). Group I include the families J558, 3609 and J606 which are located most distal from the D-region, group II contains the Vgam3.8, 3660, X24 and S107 families situated between group I families and the D-region proximal families Q52 and PC7 183 which comprise the group III $V_{H}$ gene families.

\section{RESULTS}

\section{Characteristics of mouse anti-AChR mAbs}

Monoclonal antibodies $(n=65)$ raised against AChR from Torpedo californica were obtained from fusions using pooled lymphnode cells from Balb/c $(n=3)$ or $C 57 \mathrm{~b} / / 6$ mice $(n=3)$ immunized with AChR. Anti-AChR mAbs were specific for AChR and did not bind to $\mathrm{KLH}$. Controle mAbs generated against $\mathrm{KLH}$ in both Balb/c and $\mathrm{C} 57 \mathrm{bl} / 6$ mice were obtained from simultaneous performed fusions. The fine specificity and cross-reaction with mAChR were determined in Chapter 2. The characteristics of anti-AChR mAbs are summarized in table I.

\section{$V_{H}$ gene family utilization}

The utilization of $V_{H}$ gene families by 65 anti-AChR and 20 anti-KLH hybridomas was determined by hybridization of DNA probes representative for 9 of the 12 known mouse $V_{H}$ gene families to total cytoplasmic RNA of hybridomas by slot-blot analysis. Hybridomas were assigned to a particular family if they gave a positive signal with only one of the tested $V_{H}$ gene family probes under high stringency conditions. Three hybridomas hybridized with more than one $V_{H}$ gene family probe (Q52 and PC7183) and were excluded from this study. Examples of positive hybridization signals representative for each $V_{H}$ gene family are shown in figure 1. The $V_{H}$ gene family usage by hybridomas specific for $A C h R$ or $K L H$ are shown in figure $2 A$. Fifty-eight out of $65(89 \%)$ anti-AChR hybridomas used $V_{H}$ genes from 6 $V_{H}$ gene families (J558, 3609, Vgam3.8, 3660, Q52 and PC7183), 7 anti-AChR hybridomas $(11 \%)$ could not be assigned to one of the 9 tested $V_{H}$ gene families at the stringency conditions used. The $V_{H}$ gene family usage of anti-AChR and anti-KLH mAbs was compared to the expected distribution based on $V_{H}$ gene family complexity (table II). The $V_{H}$ gene family usage of anti-AChR mAbs approached a stochastic utilization of the different $V_{H}$ gene families except for the $J 606$ family 
Table I: Characteristics of anti-AChR mAbs.

\begin{tabular}{|c|c|c|c|c|c|c|c|c|}
\hline \multicolumn{3}{|c|}{ C57bl/6 } & \multicolumn{6}{|c|}{ Specificity } \\
\hline $\mathrm{mAb}$ & $\begin{array}{l}V_{H} \text { gene } \\
\text { family }\end{array}$ & Isotype & tAChR ${ }^{a}$ & $m A C h R^{b}$ & $M I R^{C}$ & $\alpha-B T^{d}$ & $\begin{array}{l}\text { extrae } \\
\text { cell. }\end{array}$ & $\begin{array}{l}\text { intra }^{f} \\
\text { cell. }\end{array}$ \\
\hline $\mathrm{A} 2$ & $J 558$ & $\lg M$ & - & & & & & \\
\hline$A 6$ & PC7183 & $\operatorname{lgG} 2 a$ & - & & & & & - \\
\hline$A 7$ & N.A. & $\operatorname{lgG} 2 a$ & - & - & - & & • & \\
\hline A9 & $J 558$ & $\operatorname{lgG1}$ & - & $\bullet$ & - & & • & \\
\hline A10 & J558 & $\lg G 2 b$ & - & & & & & \\
\hline A11 & J558 & $\lg M$ & - & - & - & & - & \\
\hline $\mathrm{A} 13$ & N.A. & $\operatorname{lgG} 2 a$ & - & & & & - & \\
\hline A14 & 3609 & $\operatorname{lgG} 2 a$ & - & - & & & & - \\
\hline A15 & J558 & $\operatorname{lgG} 2 b$ & - & & & & & \\
\hline A18 & J558 & $\lg G_{1}$ & - & • & & & $\bullet$ & \\
\hline A19 & J558 & $\lg G 1$ & - & - & & & - & \\
\hline A20 & 3609 & $\lg A$ & - & & & & & \\
\hline A21 & J558 & $\lg { }_{1} 1$ & - & & & & - & \\
\hline A22 & N.A. & $\operatorname{lgG} 2 a$ & - & • & - & & - & \\
\hline $\mathrm{A} 23$ & J558 & $\lg A$ & - & & & & & \\
\hline $\mathrm{A} 24$ & $J 558$ & $\lg M$ & - & - & & & - & \\
\hline A.25 & $\mathrm{J} 558$ & $\lg G 1$ & - & & - & & - & \\
\hline A26 & $J 558$ & $\operatorname{lgG} 2 b$ & - & & - & & - & \\
\hline A27 & J558 & N.D. & - & & & & - & \\
\hline $\mathrm{A} 28$ & Q52 & $\lg M$ & - & & & & & \\
\hline A29 & Vgam3.8 & $\operatorname{lgG} 2 b$ & - & & $\bullet$ & & - & \\
\hline A32 & Q52 & $\operatorname{lgG} 2 a$ & - & & & & - & \\
\hline A46 & $J 558$ & $\lg G 1$ & - & & & & & - \\
\hline A49 & J558 & $\operatorname{lgG} 2 a$ & - & $\bullet$ & & & & - \\
\hline A50 & N.A. & $\lg G 2 b$ & $\bullet$ & & & & & \\
\hline A53 & Vgam3.8 & $\lg G 2 b$ & - & & & & - & \\
\hline A54 & Vgam 3.8 & $\lg G 1$ & - & & & & - & \\
\hline A55 & J558 & $\operatorname{lgG} 1$ & - & & & & - & \\
\hline A56 & J558 & $\operatorname{lgG} 2 b$ & - & & & & & \\
\hline$A 57$ & J558 & $\lg G 1$ & - & & & & & \\
\hline A58 & $N A$. & $\lg \mathrm{G} 1$ & - & - & & - & - & \\
\hline A59 & $J 558$ & $\operatorname{lgG} 2 b$ & - & & & & - & \\
\hline $\mathrm{A} 60$ & J558 & $\operatorname{lgG} 2 b$ & - & $\bullet$ & - & & - & \\
\hline A61 & J558 & N.D. & - & & & & $\bullet$ & \\
\hline A62 & Vgam3.8 & $\lg G 2 b$ & - & & & - & • & \\
\hline $\mathrm{A} 63$ & Vgam3.8 & $\lg G 2 b$ & - & & & - & - & \\
\hline A64 & J558 & $\lg G 1$ & - & & & - & - & \\
\hline \multirow[t]{2}{*}{ A65 } & Vgam 3.8 & $\lg G 2 b$ & - & & & - & - & \\
\hline & & & 38 & 11 & 8 & 5 & 25 & 4 \\
\hline
\end{tabular}




\begin{tabular}{|c|c|c|c|c|c|c|c|c|}
\hline \multicolumn{3}{|c|}{ Balb/c } & \multicolumn{6}{|c|}{ Specificity } \\
\hline mAb & $\begin{array}{l}\mathrm{V}_{\mathrm{H}} \text { gene } \\
\text { family }\end{array}$ & Isotype & $\mathrm{tAChR}^{\mathrm{a}}$ & $m A C h R^{b}$ & $M I R^{C}$ & $\alpha-\mathrm{BT}{ }^{d}$ & $\begin{array}{l}\text { extra }{ }^{\theta} \\
\text { cell. }\end{array}$ & $\begin{array}{l}\text { intraf } \\
\text { cell. }\end{array}$ \\
\hline $\mathrm{A} 1$ & J558 & $\lg \mathrm{G}_{1}$ & - & & - & & - & \\
\hline A3 & J558 & $\lg M$ & - & & - & & - & \\
\hline A4 & PC7183 & $\lg G 2 a$ & - & & & & - & \\
\hline A5 & J558 & $\lg A$ & - & & & & & \\
\hline$A 8$ & 3609 & $\lg G 1$ & - & & & - & $\bullet$ & \\
\hline $\mathrm{A} 12$ & PC7183 & $\lg G_{1}$ & - & - & & & & - \\
\hline A 16 & PC7183 & $\operatorname{lgG1}$ & - & & & & & \\
\hline A17 & N.A. & $\lg A$ & - & & & & & \\
\hline $\mathrm{A} 30$ & Q52 & $\operatorname{lgG} 1$ & - & & & & & - \\
\hline$A 31$ & Q52 & $\lg G 1$ & - & & & & & \\
\hline АЗ3 & Q52 & $\lg G 2 a$ & - & & & & & \\
\hline A34 & N.A. & $\lg G 2 b$ & - & & - & & - & \\
\hline A35 & 3660 & $\lg G 2 b$ & - & & - & & - & \\
\hline A36 & J558 & $\lg G 1$ & - & & - & & - & \\
\hline $\mathrm{A} 37$ & 3660 & $\lg G 1$ & - & - & & & & - \\
\hline A38 & 3660 & $\operatorname{lgG} 2 b$ & - & & - & & - & \\
\hline A39 & $J 558$ & $\lg G 2 b$ & $\bullet$ & & - & & - & \\
\hline $\mathrm{A} 40$ & J558 & $\mid g G 1$ & $\bullet$ & & - & & - & \\
\hline A41 & $J 558$ & $\lg G 1$ & $\bullet$ & & - & & - & \\
\hline A42 & $J 558$ & $\lg G 1$ & - & - & & & & \\
\hline$A 43$ & $J 558$ & $\mid g G 1$ & - & - & & & - & \\
\hline A44 & $\mathrm{J} 558$ & $\lg G 2 b$ & - & & & & & - \\
\hline A45 & $J 558$ & $\lg M$ & - & & & & & - \\
\hline A47 & $\mathrm{J} 558$ & $\operatorname{lgG} 2 a$ & - & - & & & & - \\
\hline A48 & $\mathrm{J} 558$ & IgG2a & - & & & & & - \\
\hline A51 & PC7183 & $\lg G 2 b$ & - & & & & & \\
\hline \multirow[t]{2}{*}{ A52 } & $\mathrm{J} 558$ & $\lg G 2$ & $\bullet$ & & & & & \\
\hline & & & 27 & 5 & 9 & 1 & 12 & 7 \\
\hline
\end{tabular}

$V_{H}$ gene family usage, isotype and specificity of mAbs directed to AChR raised in high susceptible C57bl/6 and low susceptible Balb/c mice. ${ }^{a}$ All mAbs are specific for AChR of Torpedo californica. ${ }^{b}$ MAbs cross-reactive with solubilized AChR from denervated mouse muscle. ${ }^{C}$ MIR: the main immunogenic region located on the $\alpha$-subunit ( $\alpha 67-76$ ) of AChR. ${ }^{d} \alpha$-BT: the $\alpha$-bungarotoxin binding site on the $\alpha$-subunit ( $\alpha$ 189-195) of AChR. ${ }^{\theta}$ Extracell.: epitopes located on the extracellular surface of AChR. 'Intracell.: epitopes located on the cytoplasmic surface of AChR only accessible on solubilized receptor. N.A.: mAb could not be assigned to one of the 9 tested $V_{H}$ gene families. 


\section{Hybridoma Nr:}

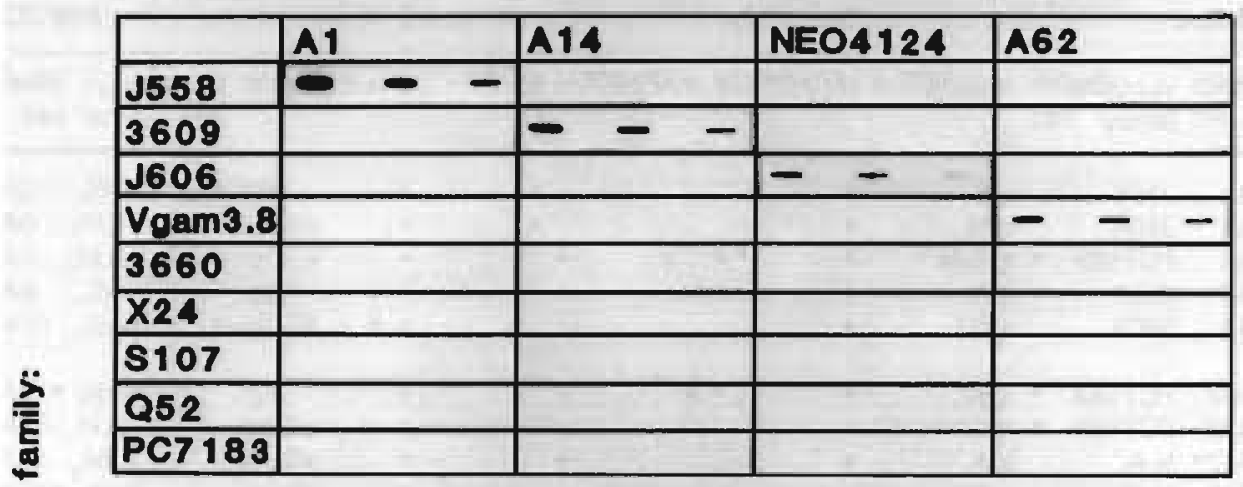

\begin{tabular}{|c|c|c|c|c|}
\hline & A38 & mAb50 & A32 & A6 \\
\hline J558 & & & & \\
\hline 3609 & & & & \\
\hline$J 606$ & & & & \\
\hline Voam3.8 & & & & \\
\hline 3660 & $-\quad-\quad-$ & & E & \\
\hline$\times 24$ & & & & \\
\hline 5107 & & $-\quad-\quad-$ & & \\
\hline Q62 & & & $-\quad-\quad-$ & \\
\hline PC7183 & & & . & - \\
\hline
\end{tabular}

Figure 1: Representative examples of slot-blot hybridization of hybridomas to $V_{H}$ gene family specific probes.

Aliquots of 1.0 .5 and $0.25 \mu \mathrm{g}$ RNA were immobilized to nitrocellulose and hybridized to probes specific for nine $V_{H}$ gene families. NEO4 124 is a mAb isolated from a 5 day old nonimmunized $B a l b / c$ mouse (10) and $\mathrm{mAb50}$ is a $\mathrm{MAb}$ against electric eel AChR.

which was significantly underrepresented $(p<0.01)$ and the Vgam3.8 family which was overrepresented $(p<0.05)$. The $V_{H}$ gene family utilization of anti-AChR hybridomas showed no bias in utilization towards $D$-proximal $V_{H}$ gene families.

An important subgroup of these anti-AChR mAbs are those cross-reacting with autologous mouse AChR which can cause EAMG. When the $V_{H}$ gene family usage of this subgroup of potential pathogenic antibodies is considered, $V_{H}$ genes from at least four different $V_{H}$ gene families are used; J558 (10/16), $3609(1 / 16), 3660$ $(1 / 16)$ and $P C 7183(1 / 16)$. No significant difference in $V_{H}$ gene family usage can be observed between mAbs crossreactive with mAChR $(n=16)$ and mAbs specific for Torpedo AChR $(n=49)\left(\chi^{2}=1.8\right.$ d.f. $\left.=2\right)$ (table Iil). 


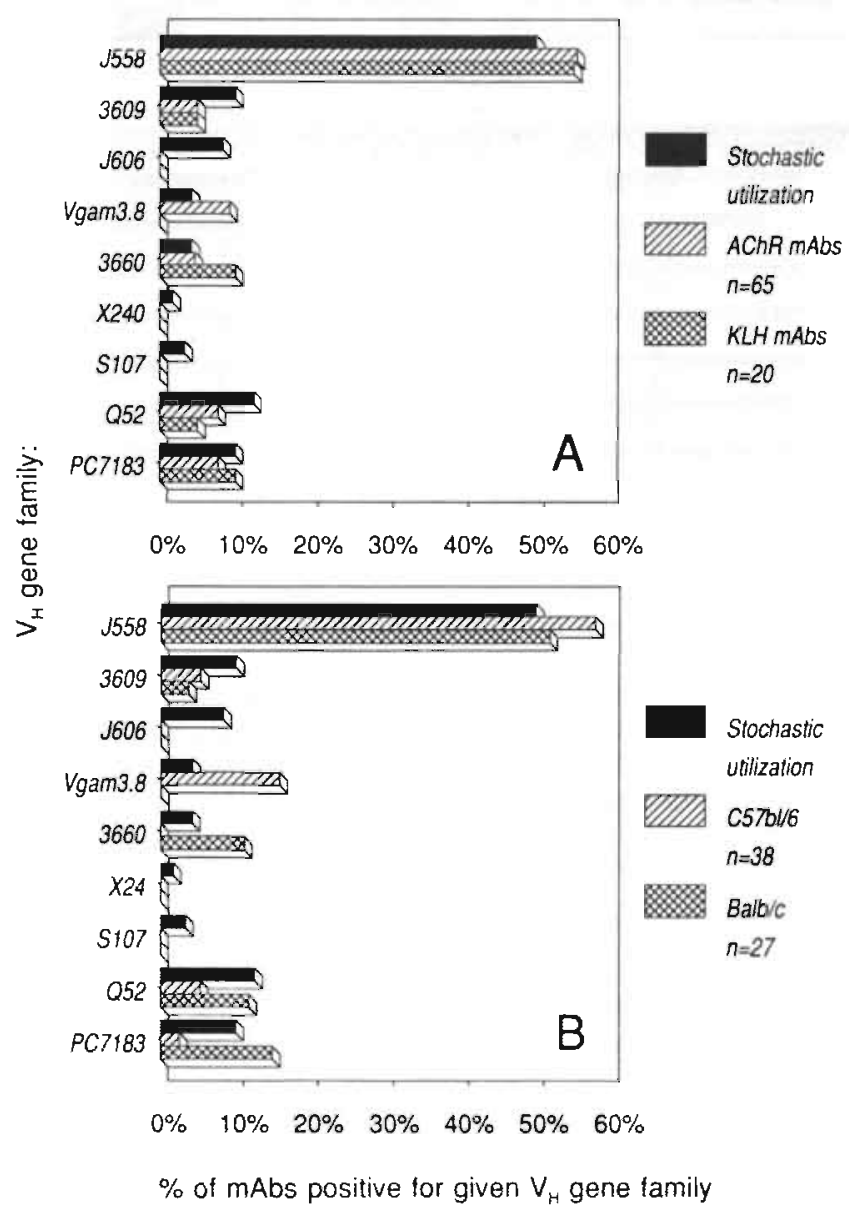

Figure 2: The $V_{H}$ gene family distribution of anti-AChR and anti-KLH mAbs over nine $V_{H}$ gene families. The $V_{H}$ family usage is expressed as the percentage of mAbs positive for a given $V_{H}$ gene family and was compared to a stochastic distribution based on the estimated size of the family. Seven anti-AChR mAbs and 3 anti-KLH mAbs could not be assigned to one of the tested $V_{H}$ gene families. (A) $V_{H}$ gene family usage of anti-AChR V.s. anti-KLH mAbs. (B) $V_{H}$ gene family usage of anti-AChR mAbs from high susceptible C57bl/6 and low susceptible Balb/c mice.

\section{$V_{H}$ gene family usage in relation to fine specificity}

In order to relate $V_{H}$ gene family usage to antibody fine specificity, mAbs were selected with similar epitope specificity to see if they were encoded by related $V_{H}$ genes. Therefore $V_{H}$ gene family usage of mAbs against the MIR ( $\left.\alpha 67-76\right)$ and the $\alpha$-BT binding site ( $\alpha 189-195)$ were analyzed. Anti-MIR mAbs $(n=17)$ were encoded by at least three different $V_{H}$ gene families; J558 (11/17), Vgam3.8 (1/17) and 3660 $(2 / 17)$. The observed $V_{H}$ family gene usage among anti-MIR mAbs $(n=17)$ and non-MIR mAbs $(n=48)$ was not significant different $\left(\chi^{2}=3.7\right.$ d. $\left.f .=2\right)$ (table III). 
Table II: The VH gene family usage of anti-AChR and anti-KLH mAbs.

\begin{tabular}{|c|c|c|c|c|c|c|c|}
\hline \multirow{3}{*}{$\frac{V_{H} \text { familya }}{J 558}$} & \multirow{3}{*}{$\frac{\text { Complexity }^{b}}{60}$} & \multirow{3}{*}{$\begin{array}{l}\% \text { of total } \\
V_{H} \text { genes } \\
48\end{array}$} & \multirow{2}{*}{\multicolumn{2}{|c|}{$\frac{\text { tAChR }}{\text { mAbs using (\%) }}$}} & \multirow{2}{*}{\multicolumn{2}{|c|}{$\begin{array}{l}\mathrm{KLH} \\
\text { mAbs using (\%) } \\
\mathrm{V}_{\mathrm{H}} \text { family }\end{array}$}} & \multirow{3}{*}{$\begin{array}{l}\text { Significance }{ }^{0} \\
\text { N.S. }\end{array}$} \\
\hline & & & & & & & \\
\hline & & & 36 & $(55)$ & 11 & $(55)$ & \\
\hline 3609 & 12 & 10 & 3 & (5) & 1 & (5) & N.S. \\
\hline J606 & 10 & 8 & 0 & (0) & 0 & ( 0 ) & $p<0.01$ \\
\hline Vgam3.8 & 5 & 4 & 6 & (9) & 0 & ( 0 ) & $p<0.05$ \\
\hline 3660 & 5 & 4 & 3 & (5) & 2 & (10) & N.S. \\
\hline X24 & 2 & 2 & 0 & (0) & 0 & ( 0 ) & N.S. \\
\hline$S 107$ & 4 & 3 & 0 & (0) & 0 & ( 0 ) & N.S. \\
\hline Q52 & 15 & 12 & 5 & (8) & 1 & (5) & N.S. \\
\hline PC7183 & 12 & 10 & 5 & ( 8$)$ & 2 & (10) & N.S. \\
\hline N.A. ${ }^{e}$ & & & 7 & (11) & 3 & (15) & N.S. \\
\hline
\end{tabular}

${ }^{2}$ The name and the relative chromosomal order of the tested $V_{H}$ gene families relative to the $D$-region (77). ${ }^{b}$ The number of $V_{H}$ genes in each family as determined by Brodeur and Riblet (37) ${ }^{c}$ The number of mAbs using genes from a particular $V_{H}$ gene family. " The distribution of $V_{H}$ gene families among anti-AChR and anti-KLH mAbs was compared to the expected distribution based on $V_{H}$ family complexity using the $\chi^{2}$ test. ${ }^{e}$ N.A.: Not assigned. RNA of these mAbs failed to hybridize to $V_{H}$ family specific probes at used stringency conditions.

Table III: Comparison of VH gene family usage of anti-AChR mAbs or subgroups of anti-AChR mAbs.

\begin{tabular}{llll}
\hline$V_{H}$ group $^{a}:$ & I & II & III \\
\hline & $\sqrt{ } 558$ & 3660 & Q52 \\
3609 & Vgam3.8 & PC7183 \\
& J606 & X24 & \\
& & $\mathrm{S} 107$ &
\end{tabular}

\begin{tabular}{|c|c|c|c|c|c|}
\hline \multicolumn{3}{|c|}{$\begin{array}{l}\text { Localization } \mathrm{b} \text { : } \\
\text { Complexityc }(\%)\end{array}$} & \multicolumn{2}{|l|}{$\begin{array}{l}\text { D-region } \\
\text { distal } \\
82(66 \%)\end{array}$} & \multirow{2}{*}{ 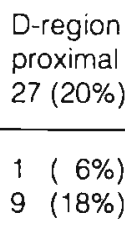 } \\
\hline A & $\begin{array}{l}\text { mAChR } \\
\text { tAChR }\end{array}$ & $\begin{array}{l}(n=16) \\
(n=49)\end{array}$ & $\begin{array}{l}11(69 \%) \\
29(59 \%)\end{array}$ & $\begin{array}{lr}1 & (6 \%) \\
8 & (16 \%)\end{array}$ & \\
\hline B & $\begin{array}{l}\text { MIR } \\
\text { non-MIR }\end{array}$ & $\begin{array}{l}(n=17) \\
(n=48)\end{array}$ & $\begin{array}{l}11(65 \%) \\
28(58 \%)\end{array}$ & $\begin{array}{ll}3 & (18 \%) \\
6 & (13 \%)\end{array}$ & $\begin{array}{l}0 \quad(0 \%) \\
10(21 \%)\end{array}$ \\
\hline C & $\begin{array}{l}\text { Balb/c } \\
\text { C57bl/6 }\end{array}$ & $\begin{array}{l}(n=27) \\
(n=38)\end{array}$ & $\begin{array}{l}15(56 \%) \\
24(63 \%)\end{array}$ & $\begin{array}{ll}3 & (11 \%) \\
6 & (16 \%)\end{array}$ & $\begin{array}{ll}7 & (26 \%) \\
3 & (8 \%)\end{array}$ \\
\hline
\end{tabular}

${ }^{a} V_{H}$ gene families were combined for statistical evaluation by the $\chi^{2}$ test. Group / comprises VHfamilies located most distal from the D-region, group $/ / V_{H}$ families are a group of small interspersed families located between the D-region distal Group / and D-region proximal group III $V_{H}$ families 052 and PC7183. Belative localization of $V_{H}$ gene families compared to the D-region. ${ }^{c}$ The complexity represents the total estimated size of $V_{H}$ gene families comprised in the combined $V_{H}$ family groups. 


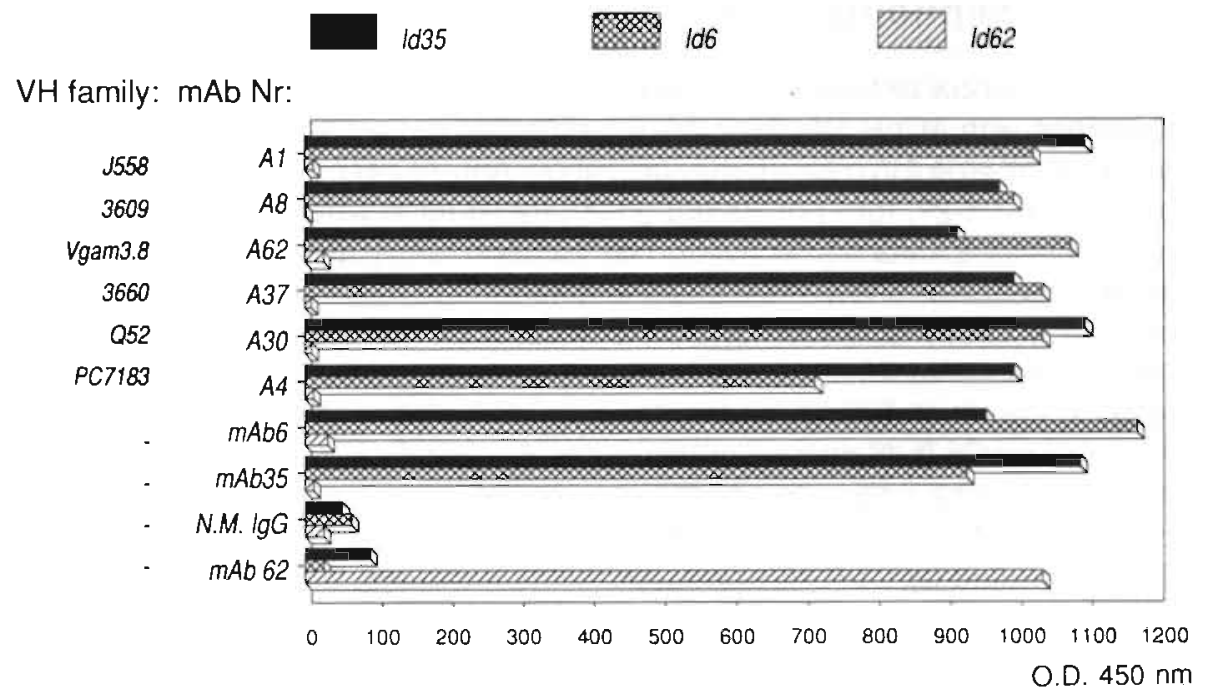

Figure 3: Anti-AChR mAbs encoded by $V_{H}$ genes from six different families express a $C R I$.

Expression of a CRI by mouse anti-AChR mAbs encoded by different $V_{H}$ gene families was determined using two affinity purified polyclonal anti-lds. $1 d 6$ and 35 are the CRls expressed by rat anti-AChR mAbs 6 and 35 respectively. Id62 is a CRl expressed by anti-thyroglobulin mAb 62. Binding of anti-lds to mouse anti-AChR mAbs was determined at $50 \%$ of the maximum binding of anti-ld to its respective idiotype.

Monoclonal antibodies directed against the $\alpha$-BT binding site $(n=6)$ are encoded by at least 3 different $V_{H}$ gene families; J558 (1/6), 3609 (1/6) and Vgam3.8 (3/6). Interesting however the Vgam3.8 family is overrepresented in anti- $\alpha$-BT binding site $\operatorname{mAbs}(50 \%)$.

\section{$V_{H}$ gene family usage in relation to idiotype expression}

To investigate the relation between expression of $\mathrm{CRI}$ and utilization of a certain $\mathrm{V}_{\mathrm{H}}$ gene family, mAbs representative for each $V_{H}$ gene family were selected and expression of CRI was determined with affinity purified polyclonal anti-idiotypes (anti-Id) which are directed to the (cross-species) CRI determinants expressed by rat anti-AChR mAb 6 and 35. Both Id 6 and 35 are expressed on mouse anti-AChR mAbs but not on control antibodies. Control anti-ld62 specific for a CRI expressed by anti-thyroglobulin antibodies does not recognize $\mathrm{CR}$ on any of the mouse anti-AChR mAbs (fig. 3). Anti-AChR mAbs expressing $C R I$ are encoded by $V_{H}$ genes from at least 6 different $V_{H}$ gene families. Thus expression of $C R I$ is irrespective of the $V_{H}$ gene family used by the mAb. 


\section{EAMG susceptibilty in relation to $V_{H}$ gene family usage}

Mouse strains show differences in their susceptibility for the induction of EAMG by immunization with AChR. We therefore investigated if disease susceptibility can be related to an aberrant $V_{H}$ gene family utilization. Anti-AChR mAbs were derived from either $\mathrm{C} 57 \mathrm{bl} / 6\left(\mathrm{H}-2^{\mathrm{d}}, \mathrm{Igh}^{\mathrm{b}}\right)$ or $\mathrm{Balb} / \mathrm{c}\left(\mathrm{H}-2^{\mathrm{b}}, \mathrm{lg} \mathrm{H}^{\mathrm{a}}\right)$ mice which show high and low susceptibility for EAMG respectively. The $V_{H}$ gene family utilization of $C 57 \mathrm{bl} / 6$ and Balb/c derived mAbs show strain specific differences which are shown in figure $2 \mathrm{~B}$. The $V_{H}$ gene family utilization in Balb/c mice shows a relative bias towards the D-region proximal families Q52 and PC7183 compared to C57bl/6 mice. This is reflected in the ratio of $J 558$ positive to Q52+PC7183 positive mAbs which is 2 for Balb/c and 7 for $C 57 b l / 6$ derived mAbs. Some $V_{H}$ gene families are exclusively used by anti-AChR mAbs originating from either one of the mouse strains. The $3660 \mathrm{~V}_{\mathrm{H}}$ gene family is exclusively used by Balb/c anti-AChR mAbs whereas the Vgam3.8 family is only used by $\mathrm{C} 57 \mathrm{bl} / 6$ anti-AChR mAbs. However, no significant difference could be observed, when $V_{H}$ gene family utilization is compared between $\mathrm{C} 57 \mathrm{bl} / 6$ and Balb/c derived mAbs $\left(\chi^{2}=3.7 \mathrm{~d} . \mathrm{f} .=2\right)$ (table III). Thus there is no indication for a biased or aberrant use of $V_{H}$ gene families that would explain the difference in disease susceptibility.

\section{DISCUSSION}

We determined the $V_{H}$ gene family utilization of anti-AChR mAbs derived from high susceptible $\mathrm{C} 57 \mathrm{bl} / 6$ and low susceptible Balb/c mice, in which EAMG was induced by immunization with Torpedo $A C h R$. $V_{H}$ gene family usage was related to $M A b$ fine specificity, expression of CRI and differences in disease susceptibility. Anti-AChR mAbs used $V_{H}$ genes from 6 out of the 9 tested $V_{H}$ gene families and $V_{H}$ gene family utilization approached a stochastic distribution over the different families. No bias in $V_{H}$ gene family usage towards D-region proximal families was observed among mAbs directed to Torpedo AChR or mAbs cross-reactive with mouse AChR. Our results are in agreement with other studies of $V_{H}$ gene family usage by antigen induced autoantibodies that show a stochastic utilization of $V_{H}$ genes from the various $V_{H}$ gene families (30-31), which resembles the $V_{H}$ gene family usage of the normal $B$ cell repertoire $(52,53)$. Anti-AChR mAbs show no bias in $V_{H}$ gene family usage towards $D$-proximal $V_{H}$ gene families as was suggested for spontaneous and antigen induced autoantibodies (27-29). However, anti-AChR mAbs show a significant deviation from stochastic usage concerning the J606 and Vgam3.8 gene families. The overrepresentation of $V_{H}$ genes from the $V_{\text {gam }} .8$ family could be due to selection of related $V_{H}$ genes in mAbs binding to a defined antigenic region (54), as was suggested by the fact that $V_{H}$ genes from this small family are preferentially expressed (50\%) by mAbs directed to the $\alpha$-BT binding site.

Subgroups of the anti-AChR mAbs used in this study are directed to well defined epitopes on the AChR. Antibodies against the MIR, a 10 amino acid epitope on the extracellular side of the $\alpha$-subunit (47) can cause acute EAMG in experimental animals by increasing AChR turnover $(3,55)$. Anti-MIR mAbs are encoded by at 
least three different $V_{H}$ gene families and we found no restricted $V_{H}$ family usage among mAbs of this specificity. However, a 10 aminoacid protein epitope like the MIR can be regarded as a group of closely overlapping epitopes (5), eliciting a heterogeneous population of anti-MIR mAbs formed by several diverse heavy chains. Similar, mAbs specific for a decapeptide of Tobacco Mosaic Virus protein (56) were encoded by diverse $V_{H}$ and $V_{L}$ genes.

Our current library of anti-AChR mAbs comprises six mAbs directed to the $\alpha$-BT binding site localized to $\alpha 189-195$ on the $\alpha$-subunit (48). Four anti- $\alpha$-BT binding site mAbs were able to inhibit $\alpha$-BT binding to both binding sites on each AChR molecule whereas two mAbs inhibited only one of the $\alpha$-BT binding sites confirming that the two $\alpha$-BT binding sites show similar epitopes as well as epitopes unique for each of the two sites $(57,58)$. A partial correlation between $V_{H}$ gene family usage and epitope specificity was demonstrated among anti- $\alpha$-BT binding site mAbs. $V_{H}$ genes from the relatively small Vgam3.8 family were found in 3 out of 6 anti- $\alpha$-BT binding site mAbs. The two mAbs that inhibit only one of the two binding sites are both encoded by the $V$ gam3.8 family suggesting that closely related $V_{H}$ chains are used.

Previously, we identified a CRI on both rat and mouse anti-AChR mAbs. Cross-reactive idiotopes were associated with the antigen binding site, i.e. paratope of anti-MIR $\mathrm{mAb}$, as well as non-paratope related framework associated cross-reactive idiotopes shared by all anti-AChR mAbs (49). In order to relate expression of CRI to $\mathrm{V}_{H}$ gene family usage we determined the appearance of a CRI on anti-AChR mAbs encoded by 6 different $V_{H}$ gene families. Expression of a CRI was found to be irrespective of the $V_{H}$ gene family used. One explanation for expression of a CRI could be that these antibodies are formed by related primary amino acid sequences of $V_{H}$ regions $(23,59)$; a high degree of idiotypic cross-reactivity is frequently found among antibodies encoded by $V_{H}$ genes from the same $V_{H}$ gene family $(24,40,60$, 61). However, expression of a CRI can also be independent of the $V_{H}$ gene family used (62). $V_{H}$ genes originating from different families could share small highly homologous DNA sequences encoding similar structural features of the antibody although the overall DNA sequence homology of the entire $V$ region is less than 70 $\%$. Expression of $C R I$ could also be a consequence of highly homologous $V_{L}$ chains. The structural basis for expression of a CRI among anti-AChR mAbs may furthermore be a consequence of shared topological elements in the three-dimensional structure which are not easily deduced from the primary amino acid structure.

The differences observed in $V_{H}$ gene family utilization of $\mathrm{C} 57 \mathrm{bl} / 6$ and $\mathrm{Ba} / \mathrm{b} / \mathrm{c}$ derived anti-AChR mAbs are characteristic for the used mouse strains as was previously demonstrated for LPS induced (63-65) or unstimulated splenic B-cells (65). However, the Vgam3.8 gene family was exclusively used by anti-AChR mAbs derived from EAMG sensitive C57bl/6 mice. Although these Vgam3.8 positive mAbs are directed against extracellular located epitopes (MIR, $\alpha$-BT binding site), only mAb 58 cross-reacted with $\mathrm{MAChR}$ and may be pathogenic.

Thus, strain dependent $V_{H}$ gene family usage resembles the usage of the normal repertoire and no association could be made between disease susceptibility and abnormalities in the $V_{H}$ gene family usage. It was shown that susceptibility to 
multiple sclerosis in both familial and sporadic MS patients is associated with a locus within the D-region proximal Ig $V_{H}$ region (66), suggesting that abnormalities within the $V_{H}$ region could contribute to genetic control of susceptibility to autoimmune disease.

Taken together these results indicate that the immune response against a large protein antigen like the $A C h R$ is encoded by many different $V_{H}$ genes originating from different $V_{H}$ gene families reflecting the polyclonal nature of anti-AChR antibodies in EAMG (67), which was also observed in MG (68). Our results are in agreement with a report of Guigou et al (69) in which the activated B cell repertoire in germinal centers of hyperplastic thymuses of MG patients closely reflected the $V_{H}$ and $V_{K}$ family usage of the normal repertoire.

\section{Acknowledgements}

We would like to thank Mieke Henfling for her indispensable contribution to the production and characterization of the anti-AChR hybridomas, and the Beatrix foundation for financial support. 


\section{REFERENCES}

1 Lindstrom J, Shelton D, Fuji Y. (1988). Myasthenia gravis. Adv. Immunol. 42:233-2.84

2 Toyka KV, Drachman D, Griffin D, Pestronk A, Windelstein J, Fischbeck K, Dao I. (1977) Myasthenia gravis. Study of humoral immune mechanisms by passive transfer to mice. N. Eng. J. Med. 296:125-131

3 Lindstrom JM, Engel AG, Seybold ME, Lennon VA, Lambert EH. (1976). Pathological mechanisms in experimental autoimmune myasthenia gravis. II. Passive transfer of experimental autoimmune myasthenia gravis in rats with anti-acetylcholine receptor antibodies. J. Exp. Med. 144:739-753

4 Tzartos SJ, Hochschwender S, Lindstrom J. (1987). Passive transfer of experimental autoimmune myasthenia gravis by monoclonal antibodies to the main immunogenic region of the acetylcholine receptor. J. Neuroimmunol. 15:185-194

5 Tzartos SJ, Barkas T, Cung MT, Kordossi A, Loutrari H, Marraud M, Papadouli I, Sakarellos C, Sophianos D, Tsikaris V. (1991). The main immunogenic region of the acetylcholine receptor. Structure and role in myasthenia gravis. Autoimmunity 8:259-270 Bos NA, Meeuwsen CG. (1989). B cell repertoire in adult antigen-free and conventional neonatal Balb/c mice. I. Preferential utilization of the $\mathrm{C}_{H}$ proximal $\mathrm{V}_{\mathrm{H}}$ gene family $\mathrm{PC} 7183$. Eur. J. Immunol. 19:1811-1815

7 Souroujon M, White-Scharf ME, Andre-Schwartz J, Gefter ML, Schwartz RS. (1988) Preferential autoantibody reactivity of the preimmmune $B$ cell repertoire in normal mice. J. immunol. 140:4173-4179

8 Dighiero G, Lim A, Lembazat MP, Kaushik A, Andrade L, Freitas A. (1988). Comparative study of $V_{H}$ gene family usage by newborn xid and non-xid mice, Newborn NZB and adult NZB mice, and by splenic and peritoneal cavity B cell compartements. Eur. J. Immunol. 18:1979-1983

9 Hartman AB, Mallet CP, Srinivasappa J, Prabhakar BS, Notkins AL, Smith-Gill SJ. (1989). Organ reactive autoantibodies from non-immunized adult Balb/c mice are polyreactive and express a non-biased $V_{H}$ gene usage. Mol. Immuol. 26:359-370

10 Hayakawa K, Carmak CE, Hyman R, Hardy RR. (1990). Natural autoantibodies to thymocytes: origin, $V_{H}$ genes, fine specificities, and the role of Thy-1 glycoprotein. J. Exp. Med. 172:869-878

11 Painter CJ, Monestier M, Chew A, Bona-Dimitriu A, Kastoury K, Bailey C, Scott VE, Sidman CL, Bona CA. (1988). Specificities and V genes encoding monoclonal autoantibodies from viable motheaten mice. J. Exp. Med. 167:1137-1153

12 Striebich CC, Miceli RM, Schulze DH, Kelsoe G, Cerny J. (1990). Antigen-binding repertoire and $\mathrm{lg} \mathrm{H}$ chain gene usage among $\mathrm{B}$ cell hybridomas from normal and autoimmune mice. J. Immunol. 144:1857-1865

13 Freitas AA, Sidman CL. (1990). VH gene family repertoire of "viable motheaten" (m€v) mice. Eur. J. Immunol. 20:1033-1037

14 Reininger L, Shibata T, Ozaki S, Shirai T, Jaton JC, Izui S. (1990). Variable region sequences of pathogenic anti-mouse red blood cell autoantibodies from autoimmune NZB mice. Eur. J. Immunol. 20:771-777

15 Eilat D, Hochberg M, Tron F, Jacob L, Bach JF. (1989). The $V_{H}$ gene sequences of anti-DNA antibodies in two different strains of lupus-prone mice are highly related. Eur. J. Immunnol. 19:1241-1246

16 Smith RG, Voss jr EW. (1990). Variable region primary structures of monoclonal anti-DNA autoantibodies from NZB/NZW F 1 mice. Mol. Immunol. 27:463-470

17 Panosian-Sahakian N, Klotz JL, Ebling F, Kronenberg M, Hahn B. (1989). Diversity of Ig $\checkmark$ gene segments found in anti-DNA autoantibodies from a single (NZBXNZW) $F_{1}$ mouse. J. Immunol. 142:4500-4506 
18 Kofler R, Noonan DJ, Strohal R, Balderas RS, Moller NPH, Dixon FJ, Theofilopoulos. (1987). Molecular analysis of the murine lupus-associated anti-self response: Involvement of a large number of heavy and light chain variable region genes. Eur. J. Immunol. 17:91-95

19 Arant SE, Griffin JA, Koopman WJ. (1986). $V_{H}$ gene expression is restricted in anti-igG antibodies from MRL autoimmune mice. J. Exp. Med. 164:1284-1300

20 Aguado MT, Balderas RS, Rubin RL, Duchosal MA, Kofler R, Birshtein BK, Secher DS, Dixon FJ, Theofilopoulos AN. (1987). Specifictiy and molecular characteristics of monoclonal IgM rheumatoid factors from arthritic and non-arthritic mice. J. Immunol. 139:10801087

21 Kastner DL, Mcintyre TM, Mallett CP, Hartmann AB, Steinberg AD. (1989). Direct quantitative in situ hybridization studies of Ig $V_{H}$ utilization. J. Immunol. 143:2761-2767

22 Komisar JL, Leung KY, Crawley RR, Talal N, Teale JM. (1989). Ig VH gene family repertoire of plasma cells derived from lupus-prone MRL/lpr and MRL/++ mice. J. Immunol. 143:340-347

23 O'Keefe TL, Bandyopadhyay S, Datta SK, Imanishi-Kari T. (1990), V region sequences of an idiotypically connected family of pathogenic anti-DNA autoantibodies. J. Immunol. 144:4275-4283

24 Victor-Kobrin C, Mansner T, Moran TM, Imanishi-Kari, Gefter M, Bona CA. (1985). Shared idiotopes among antibodies encoded by heavy-chain variable region $\left(V_{H}\right)$ gene members of the $J 558 \mathrm{VH}_{\mathrm{H}}$ family as basis for cross-reactive regulation of clones with different antigen specifity. Proc. Natl. Acad. Sci. USA. 82:7696-7700

25 Shlomchik MJ, Nemazee DA, Sato VL. van Snick J, Carson DA, Weigert MG. (1986). Variable region sequences of murine $\operatorname{lgM}$ anti-lgG monoclonal autoantibodies (rheumatoid factors). A structural explanation for the high frequency of IgM anti-lgG B cells. J. Exp. Med. 164:407-427

26 Rolink AG, Thalmann P, Berger C, Radaszkiewicz T, Melchers F. (1988). Autoreactive B-cell repertoire in mice with chronic graft versus host disease. Mol. Immunol. 25:12171222

27 Monestier M, Manheimer-Lory A, Bellon B, Painter C, Dang H, Talal N, Zannetti M, Schwartz R, Pisetsky D, Kuppers R, Rose N, Brochier J, Klaresog L, Holmdahl R, Erlanger $\mathrm{B}$, Alt $\mathrm{F}$, Bona C. (1986). Shared idiotopes and restricted immunoglobulin variable region heavy chain genes characterize murine autoantibodies of various specificities $\mathrm{J}$. Clin. Invest. 78:753-759

28 Manheimer-Lory A, Monestier M, Bellon B, Alt F, Bona A. (1986). Fine specificity, idiotype, and nature of cloned heavy-chain variable region genes of murine monoclonal rheumatoid factor antibodies. Proc. Natl. Acad. Sci. USA. 83:8293-8297

29 Trepicchio W, Barrett K. (1987). Eleven MRL-Ipr/lpr anti-DNA autoantibodies are encoded by genes from four $V_{H}$ gene families: A potentially biased usage of $V_{H}$ genes. $J$. Immunol. 138:2323-2331

30 Gleason GL, Gearhart P, Rose NR, Kuppers RC. (1990). Autoantibodies to thyroglobulin are encoded by diverse $\mathrm{V}$-gene segments and recognize restricted epitopes. J. Immunol. 145:1768-1775

31 Ewulona UK, Nell LJ, Thomas JW. (1990). $V_{H}$ and $V_{L}$ gene usage by murine IgG antibodies that bind autologous insulin J. Immunol. 144:3091-3098

32 HolmdahI R, Bailey C, Enander I, Mayer R, Klareskog L, Moran T, Bona C. (1989). Origin of the autoreactive anti-type II collagen response; II. Specificities, Antibody isotypes and usage of $V$ gene families of anti-type II collagen B cells. J. Immunol. 142:1881-1886

33 Brodeur PH, Riblet R. (1984). The immunoglobulin heavy chain variable region (Igh-V) locus in the mouse. I. One hundered Igh-V genes comprise seven families of homologous genes. Eur. J. Immunol. 14:92 
34 Winter E, Radbruch A, Krawinkel U. (1985). Members of a novel VH gene family are found in VDJ regions of polyclonally activated B-lymphocytes. EMBO J. 4:2861-2867

35 Kofler R. (1988). A new VH gene family. J. Immunol. 140:4031-4034

36 Reininger L, Ollier P, Poncet P, Kaushik A, Jaton JC. (1987). Novel V genes encode virtually identical variable regions of six murine monoclonal anti-bromelain-treated red blood cell autoantibodies. J. Immunol. 138:316-323

37 Pennell CA, Sheenan KM, Brodeur PH, Clarke SH. (1989). Organization and expression of $\mathrm{V}_{\mathrm{H}}$ gene families preferentially expressed by Ly-1+(CD5) B cells. Eur. J. Immunol. 19:2115-2121

38 Meek K, Rathburn G, Reininger L, Jaton JC, Kofler R, Tucker PW, Capra JD. (1990). Organization of the murine immunoglobulin $V_{H}$ complex: placement of two new $V_{H}$ gene families ( $V_{H} 10$ and $V_{H} 11$ ) and analysis of $V_{H}$ family clustering and interdigitation. Mol. Immunol. 27:1073-1081

39 Brodeur PH, Osman GE, Mackle JJ, Lalor TM. (1988). The organisation of the mouse Igh-V locus. J. Exp. Med. 168:2261-2278

40 Bellon B, Manheimer-Lory A, Monestier M, Dimitriu-Bona A, Alt F, Bona C. (1987). High frequency of autoantibodies bearing cross-reactive idiotopes among hybridomas using $\mathrm{V}_{\mathrm{H}} 7183$ genes prepared from normal and autoimmune murine strains. J. Clin. Invest. 79:1044-1053

41 Dildrop R, krawinkel U, Winter E, Rajewsky K. (1985). $V_{H}$ gene expression in murine lipopolysaccharide blasts distributes over the nine known $V_{H}$-gene groups and may be random. Eur. J. Immunol. 15:1154-1156

42 Yancopoulos GD, Maylynn BA, Alt FW. (1988). Developmentally regulated and strainspecific expression of murine $V_{H}$ families. J. Exp. Med. 168:417-435

43 Dighiero G, Lymberi P, Holmberg D, Lundquist I, Couthinio A, Avrameas S. (1985). High frequency of natural autoantibodies in normal newborn mice. J. Immunol. 134:765-771

44 Holmberg D. (1987). High connectivity, natural antibodies preferentially use 7183 and QUPC52 V $V_{H}$ families. Eur. J. Immunol. 17:399-403

45 Fuchs S, Nevo D, Tarrab-Hadazi R. (1976). Strain differences in the autoimmune response of mice to acetylcholine receptors. Nature 233:329-330

46 Berman PW, Patrick J. (1980). Linkage between the frequency of muscular weakness and loci that regulate immune responsiveness in murine experimental myasthenia gravis. J. Exp. Med. 152:507-520

47 Tzartos SJ, Kokla A, Walgrave S, Conti-Tronconi B. (1988). Localization of the main immunogenic region of human muscle acetylcholine receptor to residues $67-76$ of the $\alpha$-subunit. Proc. Natl. Acad. Sci. USA. 85:2899-2903

48 Tzartos SJ, Remoundos MS. (1990). Fine localization of the major $\alpha$-bungarotoxin site to residues $\alpha 189-195$ of Torpedo acetylcholine receptor. Residues 189, 190 and 195 are indispensable for binding. J. Biol. Chem. 265:21462-21467

49 Verschuuren JJGM, Graus YMF, Tzartos S, Van Breda Vriesman PJC, De Baets MH. (1991). Paratope-and framework- related cross-reactive idiotopes on anti-acetylcholine receptor antibodies. J. Immunol. 146:941-948

50 Zanetti M, De Baets M, Rogers J. (1983) High degree of idiotypic cross-reactivity among murine monoclonal antibodies to thyroglobulin. J. Immunol. 131:2452-2457

51 Sambrook J, Fritsch E, Maniatis T. (1989). Molecular cloning: A laboratory manual (Cold Spring Harbor Laboratory, Cold Spring Harbor, NY). pp. 7.12-7.15

52 Andrade L, Freitas AA, Huetz F, Poncet P, Coutinhio A. (1989). Immunoglobulin VH gene expression in Ly-1+ and conventional B lymphocytes. Eur. J. Immunol. 19:1117-1122

53 Rolink AG, Thalmann P, Kikuchi Y, Erdei A. (1990). Characterization of the interleukin 5-reactive splenic B cell population. Eur. J. Immunol. 20:1949-1956 
54 Caton AJ, Brownlee GG, Staudt LM, Gerhard W. (1986). Structural and functional implications of a restricted antibody response to a defined antigenic region of the influenza virus hemagglutinin. EMBO J. 5:1557-1587

55 Tzartos SJ, Lindstrom JL. (1980). Monoclonal antibodies to probe acetylcholine receptor structure: localization of the main immunogenic region and detection of similarities between subunits. Proc. Natl. Acad. Sci. USA. 77:755-759

56 Andria ML, Levy S, Benjameni E. (1990). Diverse $V_{H}$ and $V_{L}$ genes are used to produce antibodies against a defined protein epitope. J. Immunol. 144:2614-2619

57 Withing A, Vincent A, Newsom-Davis J. (1985). Monoclonal antibodies to Torpedo acetylcholine receptor. Characterisation of antigenic determinants within the cholinergic binding site. Eur. J. Biochem. 150:533-539

58 Dowding A, Hall ZW. (1987). Monoclonal antibodies specific for each of the two toxin-binding sites of Torpedo acetylcholine receptor. Biochemistry 26:6372-6381

59 Parhami-Seren B, Sharon J, Margolies MN. (1990). Structural characterization of H chain-associated idiotopes of anti-p-azophenylarsonate monoclonal antibodies. J. Immunol. 144:4426-4433

60 Nahmias C, Cazaubon S, Strosberg AD. (1989). A rabbit antiserum detects a $V_{H} J 558$ subgroup marker highly expressed among anti-alprenolol antibodies. J. Immunol. 142:871-876

61 Hirashima K, Zenita K, Takada A, Kitahara A, Ishihara G, Harada R, Ohmori K, Hirohashi S, Kyoizumi S, Akiyama M, Kannagi R. (1990). High idiotypic connectivity of the $V_{H}$ 7183-encoded antibodies directed to a murine carbohydrate antigen, lewis $Y$, as ascertained by syngeneic anti-idiotype monoclonal antibodies. J. Immunol. 145:224-232

62 Moran TM, Monestier M, Lai ACK, Norton G, Reale MA, Thompsom MA, Schulman JL, Riblet R, Bona C. (1987). Characterization of variable-region genes and shared crossreactive idiotypes of antibodies specific for antigens of various Influenza viruses. Viral Immunol.1:1-12

63 Wu GE, Paige CJ. (1986). VH gene family utilization in colonies derived from $B$ and pre-B cells detected by RNA colony blot assay. EMBO J. 5:3475-3481

64 Schulze DH, Kelsoe G. (1987). Genotypic analysis of B cell colonies by in situ hybridization; stochiometric expression of three $\mathrm{V}_{\mathrm{H}}$ families in adult $\mathrm{C} 57 \mathrm{bl} / 6$ and Balb/c mice. J. Exp. Med. 166: 163-172

65 Yancopoulos GD, Malynn BA, Alt FW. (1988). Developmentally regulated and strainspecific expression of murine $V_{H}$ gene families. J. Exp. Med. 168:417-435

66 Walter MA, Gibson WT, Ebers GC, Cox DW. (1991). Susceptibility to multiple sclerosis is associated with the proximal immunoglobuline heavy chain variable region. J. Clin. Invest. 87:1266-1273

67 Bionda A, De Baets MH, Tzartos SJ, Lindstrom JM, Weigle, Theophilopoulos. (1984). Spectrotypic analysis of antibodies to acetylcholine receptors in experimental autoimmune myasthenia gravis. Clin. Exp. Immunol. 57:41-50

68 Tzartos SJ, Seybold ME, Lindstrom.JM. (1982). Specificties of antibodies to acetylcholine receptors in sera from myasthenia gravis patients measured by monoclonal antibodies. Proc. Natl. Acad. Sci. USA. 79:188-192

69 Guigou V, Emilie D, Berrih-Aknin S, Fumoux F, Fougereau M, Schiff C. (1991). Individual germinal centers of myasthenia gravis human thymuses contain polyclonal activated $B$ cells that express all the $V_{H}$ and $V_{K}$ families. Clin. Exp. Immunol. 83:262-266 


\section{Chapter 6}

\section{$V_{H}$ gene family utilization of rat anti-acetylcholine receptor monoclonal antibodies}

Yvo M.F. Graus, Nico A. Bos, Socratez J. Tzartos,

Peter J.C. van Breda Vriesman and Marc H. De Baets 


\section{$\mathrm{V}_{\mathrm{H}}$ gene family utilization of rat anti-acetylcholine receptor monoclonal antibodies}

\section{ABSTRACT}

The diversity of $V_{H}$ genes encoding rat anti-AChR mAbs was investigated by determining the $V_{H}$ gene family utilization using family specific probes for known mouse $V_{H}$ gene families. Mouse $V_{H}$ gene family probes could identify homologous $V_{H}$ gene families in the rat. Analogous to the mouse, all tested rat hybridomas reacted with one particular mouse $V_{H}$ gene family probe at the RNA level and not with the other tested $V_{H}$ gene family probes. Rat $V_{H}$ gene families corresponding to 11 of 12 mouse $V_{H}$ gene families were found in germline DNA from four rat strains. Considerable differences in $V_{H}$ gene family complexity were found between rat and mouse. A panel of 21 rat anti-AChR mAbs are encoded by 8 different $V_{H}$ gene families. The $V_{H}$ genes encoding anti-AChR mAbs did not follow a stochastic distribution over the different $V_{H}$ gene families due to overrepresentation of the $\mathrm{S} 107$ and underrepresentation of the $X 24 V_{H}$ gene families. A partial correlation between $V_{H}$ gene family utilization and $\mathrm{mAb}$ fine specificity was found. MAbs against the main immunogenic region, showing pathogenic potential in vivo or in vitro, were most frequently encoded by $V_{H}$ genes from the Q52 family, whereas non pathogenic mAbs against intracellular epitopes were most frequently encoded by $V_{H}$ genes from the PC7183 family. Anti-AChR mAbs expressing cross-reactive idiotopes were not characterized by a particular $V_{H}$ gene family utilization. 


\section{INTRODUCTION}

In myasthenia gravis autoantibodies against the acetylcholine receptor arise, which cause loss of AChRs and failure of neuromuscular transmission. Experimental autoimmune myasthenia gravis can be induced in rats by immunization with AChR (1), and provides an excellent model for studying the anti-AChR antibody response (2). Rat anti-AChR monoclonal antibodies have been extensively characterized and have provided much information about the antigenicity of AChR (3-6), and the pathogenic mechanisms that cause AChR loss (7-9). However, no information is available about the diversity of genes encoding rat anti-AChR mAbs. It was previously suggested that murine autoantibodies are encoded by a restricted number of $V_{H}$ genes $(10,11)$, which led to the hypothesis that autoimmune disease may be related to a defective control of $V_{H}$ gene expression (12). The diversity in $V_{H}$ genes encoding rat anti-AChR mAbs was determined using mouse $V_{H}$ gene family specific probes. The mouse immunoglobulin heavy chain variable region $\left(\mathrm{lg} V_{H}\right)$ locus is well characterized. Mouse $V_{H}$ genes are classified into $12 V_{H}$ gene families, containing $V_{H}$ genes with more than $80 \%$ homology whereas the homology between different families is less than $70 \%$ (13). Therefore, we used $V_{H}$ gene familiy specific probes for 12 known mouse $V_{H}$ gene families to identify corresponding rat $V_{H}$ gene families in the germline DNA of four different rat strains. It was verified whether members of these $V_{H}$ gene families were actually expressed in rat anti-AChR hybridomas and whether these hybridomas show a random or restricted usage of the different $V_{H}$ gene families. Furthermore, the relation between $V_{H}$ gene family utilization and mAb fine specificity, pathogenicity and idiotype expression of antiAChR mAbs was determined.

The complexity of the rat $\lg V_{H}$ gene locus and the utilization of $V_{H}$ gene families in rat anti-AChR mAbs were determined. Rat $V_{H}$ gene families corresponding to 11 out of the 12 mouse $V_{H}$ gene families were found in rat germline DNA. Rat anti-AChR mAbs were encoded by 8 different $V_{H}$ gene families and did not show a stochastic distribution over the different $V_{H}$ gene families. Members of the $Q 52$ family were frequently found in pathogenic mAbs directed against the MIR whereas members of the PC7183 family were most frequently used by mAbs against intracellular located epitopes. No relation between expression of a CRI and utilization of a particular $V_{H}$ gene family could be demonstrated.

\section{MATERIAL AND METHODS}

\section{Genomic DNA and Southern blot analysis}

High molecular weight DNA from liver of PVG, AO, BN, Louvain/A rats, and BALB/C mice was isolated as previously described (14).

Liver DNA was digested to completion with Eco RI and electrophoresed on $0.7 \%$ agarose gels, blotted to nylon filters and hybridized to $32 \mathrm{P}$-labeled $\mathrm{V}_{\mathrm{H}}$ gene probes at $65^{\circ} \mathrm{C}$ for $14-16 \mathrm{hrs}$ in hybridization mix, containing $0.5 \mathrm{M} \mathrm{NaHPO}_{4}, 1 \% \mathrm{w} / \mathrm{V} \mathrm{BSA}$, $1 \mathrm{mM}$ EDTA, 3\% w/v SDS.

Filters were washed at $65{ }^{\circ} \mathrm{C}$, once in $40 \mathrm{mM} \mathrm{NaHPO}{ }_{4}, 2 \% \mathrm{w} / \mathrm{v}$ SDS, $1 \mathrm{mM}$ EDTA and $0.5 \% \mathrm{w} / \mathrm{v}$ BSA and $5-8$ times in $40 \mathrm{mM} \mathrm{NaHPO}{ }_{4}, 1 \% \mathrm{w} / \mathrm{v}$ SDS, $1 \mathrm{mM}$ EDTA. 
Sealed filters were exposed to Kodak XAR-5 films at $-70^{\circ} \mathrm{C}$ using an intensifying screen (Du Pont) for one to two weeks.

The complexity of the rat $V_{H}$ gene families was defined as the maximal number of different bands in a Eco Rl digest of liver DNA derived from PVG, AO, BN and Louvain/A rats after hybridization with a $V_{H}$ gene family specific probe.

\section{DNA probes}

DNA probes representative for the mouse $V_{H}$ gene families J558, PC7183, Q52, J606, 3660, S107 and X24 used in this study were previously described (15). The $V_{H}$ 23-9 probe $\left(V_{H} 3609\right.$ ) is a 500 bp Bam HI-Pst I fragment containing a $V_{H}$ sequence belonging to the 3609 family. The Vgam3.8 probe contains a $550 \mathrm{bp}$ Pst 1 -Eco R1 fragment of the sequence of Vgam3.8. The $V_{H} 10$ probe is a $500 \mathrm{bp}$ Pst I fragment from MRL-DNA4 and the $V_{H} 11$ probe is a $290 \mathrm{bp}$ Dra I-Pst I fragment from clone pCP12 (16). These probes were gifts from Drs. D. Holmberg, J. Kearney, F. Alt, D. Schulze, and D. Capra.

\section{Rat anti-AChR mAbs}

Rat monoclonal antibodies were raised against human, fetal calf, electric eel and native, SDS denatured or isolated subunits of Torpedo californica AChR, as was previously described (3-5).

\section{Analysis of cross-reactive idiotopes on rat anti-AChR mAbs}

Cross-reactive idiotopes specific for anti-AChR mAbs were defined by polyclonal affinity purified anti-idiotype antibodies (anti-ld) against rat anti-AChR mAb 6 (17). Binding of anti-ld to solidphase mAbs was described in detail in chapter 4 . Cross-reactive idiotopes associated with the antigen combining site were determined by a solidphase antigen binding inhibition assay. Briefly, 96 wells microtiterplates (Flow ICN, Amsterdam, The Netherlands) were coated with $50 \mu \mathrm{l}$ antiAChR mAb $(5 \mu \mathrm{g} / \mathrm{ml})$ for $1 \mathrm{hr}$ at $37^{\circ} \mathrm{C}$. After washing 3 times with $\mathrm{H}_{2} \mathrm{O}+0.5 \% \mathrm{v} / \mathrm{v}$ Tween 20, plates were incubated with PBS $+0.5 \% \mathrm{w} / \mathrm{v}$ BSA and $0.5 \% \mathrm{v} / \mathrm{v}$ Tween 20 for 15 minutes at roomtemperature. Subsequently, increasing amounts of affinity purified anti-ld 6 were incubated overnight. Without intermediate washing, a previously determined limiting concentration $\left(10^{-9} \mathrm{~mol} / \mathrm{l}\right)$ of $125 \mathrm{I}-\alpha-\mathrm{BT}$ labeled Torpedo AChR (125I- $\alpha$-BT-tAChR) was incubated for 4 hours. After washing with PBS +0.5 $\% \mathrm{v} / \mathrm{v}$ Triton $\mathrm{X}-100+0.02 \% \mathrm{NaN}_{3}$, bound radioactivity was counted with a gamma counter. The percentage inhibition of AChR binding was calculated as follows:

[(Average of duplicate wells with ${ }^{125}{ }^{1-\alpha} \alpha$-BT-tAChR alone)-(Average of duplicate wells in which $1251-\alpha$-BT-tAChR was tested in the presence of anti-Id 6)/Average of duplicate wells with ${ }^{125}$ - $\alpha$-BT-tAChR alone] $\times 100$

\section{RNA slot-blot hybridization}

Total cytoplasmic RNA of $10^{8}$ viable hybridoma cells was prepared according to Maniatis et al (18). RNA samples were diluted in $20 \times$ SSC to a range of $1,0.5,0.25$ $\mu \mathrm{g}$ and immobilized on B85 nitrocellulose filters (Scheicher and Schuell, 's-Hertogenbosch, The Netherlands) using a Minifold II slot-blot manifold. Nitrocellulose filters were air dried and baked at $80^{\circ} \mathrm{C}$ for 2 hours. Filters were prehybridized for 
4 hours at $42^{\circ} \mathrm{C}$ then hybridized with ${ }^{32} \mathrm{P}$-labeled DNA probes (approximately $5 \times 10^{6}$ $\mathrm{cpm} / \mathrm{ml}$ ) for 16 hours at $42^{\circ} \mathrm{C}$ and subsequently washed in $3 \times \mathrm{SSC}, 0.1 \% \mathrm{w} / \mathrm{v}$ SDS and twice in $1 \times \mathrm{SSC}, 0.1 \% \mathrm{w} / \mathrm{v}$ SDS at $42^{\circ} \mathrm{C}$.

\section{Statistical analysis}

The $\mathrm{V}_{\mathrm{H}}$ gene family utilization of rat anti-AChR mAbs was compared to a stochastic distribution by the $\chi^{2}$ test (19).

\section{RESULTS}

\section{$V_{H}$ gene family expression in rat anti-AChR mAbs}

In order to verify whether rat $V_{H}$ gene families analogous to known mouse $V_{H}$ gene families are expressed in rat hybridomas, we determined the $V_{H}$ gene family ultilization of a panel of 21 rat anti-AChR hybridomas using probes specific for mouse $V_{H}$ gene families. All tested rat anti-AChR hybridomas showed a clear positive hybridization signal to a single mouse $V_{H}$ gene family probe. All nine tested mouse $V_{H}$ gene families except for the $X 24 V_{H}$ gene family, were represented in these rat anti-AChR mAbs. Hybridization signals representative for each $V_{H}$ gene family are shown in figure 1.

\section{The complexity of the rat $V_{H}$ gene locus}

After demonstrating that mouse $V_{H}$ gene family probes are capable of discriminating between different rat $V_{H}$ gene families, the $\lg V_{H}$ gene locus in the rat was characterized by Southern blot analysis of genomic DNA of PVG, AO, BN and Lou/a rats using probes representing 11 of the 12 known mouse $V_{H}$ gene families. All of the tested mouse $V_{H}$ gene family probes hybridized to nonoverlapping patterns of Eco RI restriction fragments of rat liver DNA (fig. 2). The number of rat Eco RI fragments hybridizing with each mouse $V_{H}$ gene family probe is an estimate for the minimum size or complexity of the corresponding rat $V_{H}$ gene family. A total of 132 Eco $R$ I fragments hybridizing with the 11 mouse $V_{H}$ gene family probes was comparable to the 127 fragments found in the mouse. However, considerable differences in the complexity of individual rat $V_{H}$ gene families corresponding to the 11 mouse families were found (table I). The rat $V_{H}$ gene families corresponding to the mouse families PC7183, J606, S107, X24, $V_{H} 10$ and $V_{H} 11$ showed more fragments than in the mouse. Especially the 2 member mouse families $X 24, V_{H} 10$ and $V_{H} 11$ are much larger in the rat showing 18,11 and 11 fragments respectively. The Q52, 3609, Vgam3.8 and 3660 families are equal of size in both rat and mouse. The $J 558$ is the largest mouse $V_{H}$ gene family containing at least 60 members (47 $\%)$. The corresponding rat $V_{H}$ gene family only showed 16 fragments $(12 \%)$. The largest rat $V_{H}$ gene family is analogous to the PC7183 family and showed 19 fragments making up $14 \%$ of the $V_{H}$ genes in the rat. The one member mouse $V_{H}$ gene family $V_{H} 12$ was not yet tested on rat DNA. 


\begin{tabular}{|c|c|c|c|c|c|}
\hline & & & Hybridoma & Nr: & \\
\hline & & mAb 28 & mAb 8 & mAb 203 & $\mathrm{mAb}$ \\
\hline & $\mathbf{J 6 6 8}$ & $100=$ & & & \\
\hline & 3609 & & $-\quad-$ & & \\
\hline & $\mathrm{J606}$ & & & $-\quad--$ & \\
\hline & Voam3.8 & & & & $-\quad-\quad-$ \\
\hline & 3660 & & & & \\
\hline & $\times 24$ & & & & \\
\hline & $\$ 107$ & & & & \\
\hline ते & Q62 & & & & \\
\hline 5 & PC7 183 & & & & \\
\hline$\frac{5}{8}$ & & & & & \\
\hline f & & mAb 14 & mAb 47 & mAb 35 & $\mathrm{mAb} 19$ \\
\hline$>$ & $\frac{J 558}{3609}$ & & & 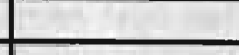 & \\
\hline & $\begin{array}{l}3608 \\
J 606\end{array}$ & & & 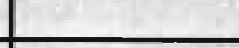 & \\
\hline & $\frac{\mathrm{J}}{\mathrm{Van} \mathrm{m}^{3} 8}$ & & & & \\
\hline & Votins.o & & & & \\
\hline & 3660 & $-\quad-=$ & & & 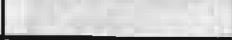 \\
\hline & $\times 24$ & & & & \\
\hline & 3107 & & $0--$ & & 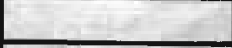 \\
\hline & Q52 & & & $-\quad-$ & \\
\hline & PC7 183 & & & & - \\
\hline
\end{tabular}

Figure 1: Slot-blot hybridizations of rat anti-AChR mAbs

Representative examples of slot-blot hybridization of rat anti-AChR hybridoma RNA to mouse $V_{H} g e n e$ family specific probes. Aliquots of $1,0.5$ and $0.25 \mu \mathrm{g}$ hybridoma RNA were immobilized to nitrocellulose and hybridized to probes specific for $9 V_{H}$ gene families.

The $V_{H}$ gene family usage of rat anti-AChR mAbs is non-stochastic

The $V_{H}$ gene family utilization found among rat anti-AChR mAbs was compared to the stochastic distribution over the different $V_{H}$ gene families based on the family complexity in the rat (fig. 3 ). The $V_{H}$ gene family utilization of rat anti-AChR mAbs showed several deviations from a stochastic distribution. None of these mAbs used a $V_{H}$ gene from the $X 24$ family, whereas the small $S 107$ family was markedly overrepresented. The $V_{H}$ gene family utilization was significantly different $(p<0.05)$ from a stochastic distribution mainly due to overrepresentation of the S107 family. 

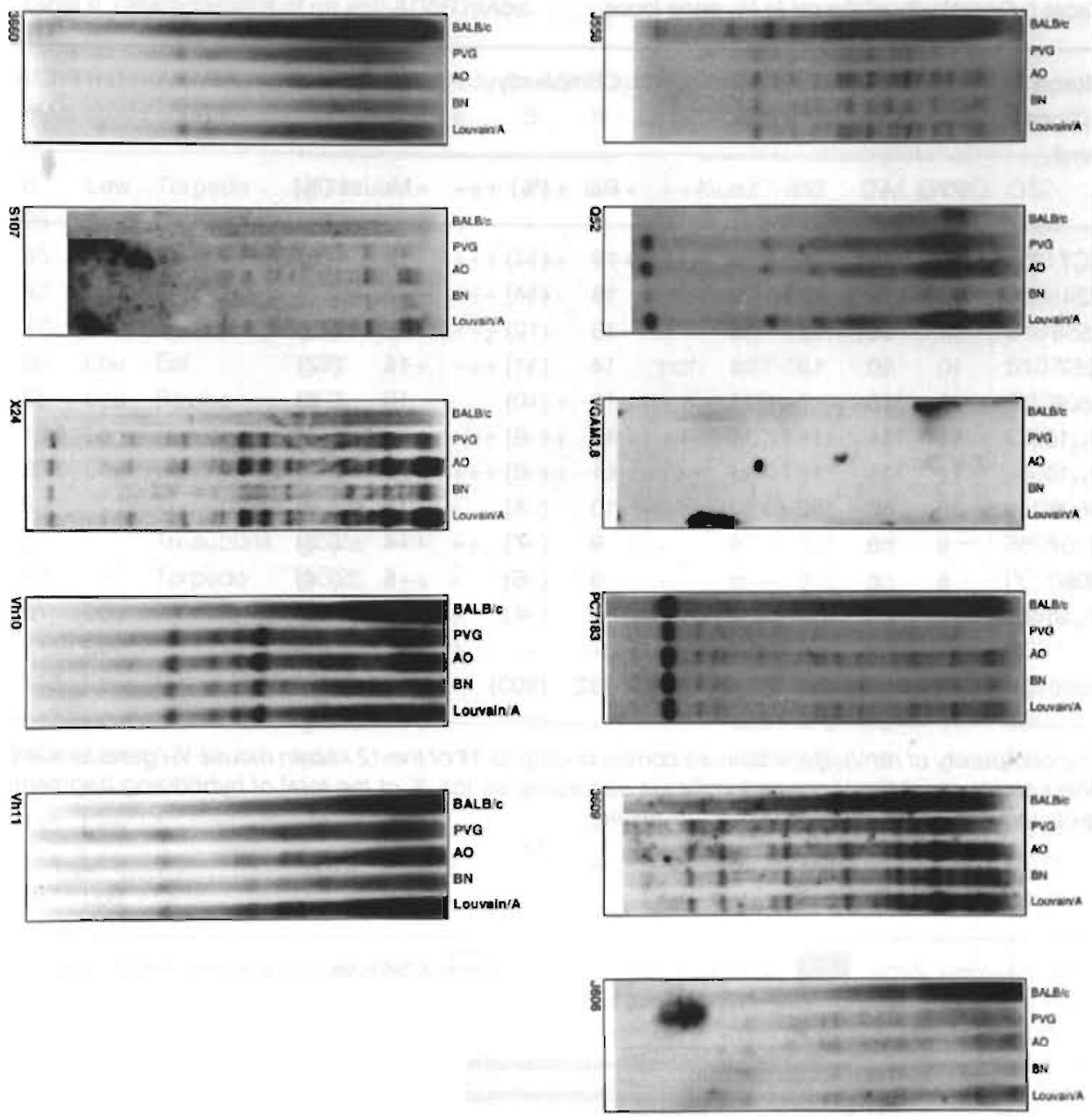

Figure 2: Rat $V_{H}$ gene families corresponding to mouse $V_{H}$ gene families detected in germline DNA by Southern-blot analysis.

Liver DNA from PVG, AO, BN, LOU/A rats and Balb/C mice was digested with ECo RI, separated on a $0.7 \%$ agarose gell, blotted and hybridized to probes representative for 11 known mouse $V_{H}$ gene families. Each mouse $V_{H}$ gene tamily probe displays a different set of fragments. The number of restriction fragments is an estimate for the minimun size of the rat $V_{H}$ gene family.

\section{$V_{H}$ gene family utilization in relation to $m A b$ specificity}

The panel of rat anti-AChR mAbs used for determination of $V_{H}$ gene family utilization comprises 9 mAbs directed against the MIR on the extracellular surface of AChR and 12 against well defined epitopes on the intracellular surface of AChR (table II). MAbs with fine specificity for the MIR located at residue 67-76 of the $\alpha$-subunit were encoded by at least $4 \mathrm{~V}_{H}$ gene families (J558: 2/9, Q52: 4/9, S107: 2/9, J606: 1/9). 
Table I: Complexity of the rat $\lg V_{H}$ gene locus.

\begin{tabular}{|c|c|c|c|c|c|c|c|c|}
\hline \multirow{3}{*}{$\begin{array}{l}\text { Mouse } \\
\text { VH gene } \\
\text { family } \\
\text { PC7183 }\end{array}$} & \multicolumn{4}{|c|}{$\begin{array}{l}\text { Number of hybridizing } \\
\text { Eco RI bands }\end{array}$} & \multicolumn{4}{|c|}{ Complexity } \\
\hline & \multirow{2}{*}{$\frac{\text { PVG }}{16}$} & \multirow{2}{*}{$\frac{A O}{19}$} & \multirow{2}{*}{$\frac{\mathrm{BN}}{8}$} & \multirow{2}{*}{$\frac{\text { Lou/A }}{18}$} & \multirow{2}{*}{$\frac{\text { Rat }}{19}$} & \multirow{2}{*}{$\frac{(\%)}{(14)}$} & \multicolumn{2}{|c|}{ Mouse (\%) } \\
\hline & & & & & & & 12 & $(9)$ \\
\hline$\times 24$ & 18 & 18 & 13 & 18 & 18 & $(14)$ & 2 & (2) \\
\hline J558 & 14 & 16 & 12 & 16 & 16 & (12) & 60 & $(47)$ \\
\hline Q52 & 10 & 10 & 13 & 14 & 14 & (11) & 15 & (12) \\
\hline J606 & 13 & 13 & 7 & 13 & 13 & (10) & 10 & ( 8$)$ \\
\hline$V_{H^{10}}$ & 11 & 11 & 11 & 11 & 11 & ( 8$)$ & 2 & (2) \\
\hline$V_{H^{11}}$ & 11 & 11 & 11 & 11 & 11 & ( 8$)$ & 2 & ( 2$)$ \\
\hline 3609 & 10 & 10 & 10 & 10 & 10 & ( 8$)$ & 10 & (8) \\
\hline 5107 & 9 & 8 & 7 & 9 & 9 & $(7)$ & 4 & (3) \\
\hline 3660 & 6 & 6 & 6 & 6 & 6 & (5) & 5 & (4) \\
\hline Vgam3.8 & 1 & 5 & 5 & 5 & 5 & (4) & 5 & (4) \\
\hline Total & & & & & 132 & $(100)$ & $\{27$ & $(100)$ \\
\hline
\end{tabular}

The complexity of rat $V_{H}$ gene families corresponding to 11 of the 12 known mouse $V_{H}$ gene families. The complexity of the $V_{H}$ gene families is expressed as the \% of the total of hybridizing fragments detected with all $V_{H}$ gene family probes tested.

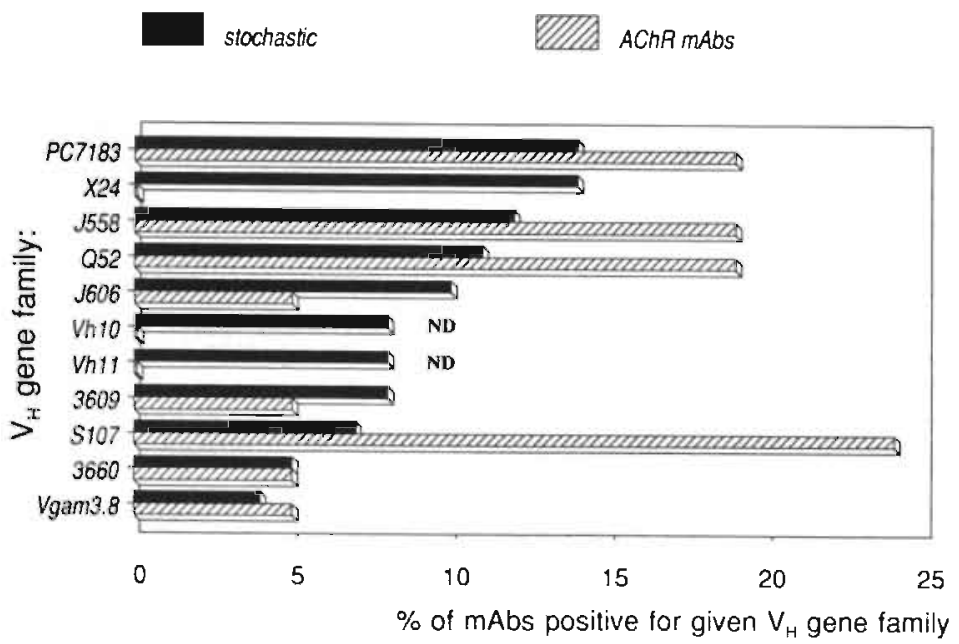

Figure 3: The $V_{H}$ gene familiy utilization of rat anti-AChR mAbs.

The distribution of rat anti-AChR mAbs over the nine tested $V_{H}$ gene families. The $V_{H}$ gene family utilization was expressed as the percentage of mAbs positive for a given $V_{H}$ gene family, and was compared to a stochastic distribution based on the complexity of these families in the rat. ND: not done. 
Table Il: Characteristics of rat anti-AChA mAbs.

\begin{tabular}{|c|c|c|c|c|c|c|c|c|c|c|c|}
\hline \multicolumn{2}{|c|}{ AChR Rat } & \multirow{2}{*}{$\begin{array}{l}\text { AChRa } \\
\text { source }\end{array}$} & \multirow[t]{2}{*}{ Isotype } & \multicolumn{5}{|c|}{ Specificity for AChR fromb } & \multirow{2}{*}{$\begin{array}{l}\text { Fine } \\
\text { specificityc }\end{array}$} & \multirow{2}{*}{$\begin{array}{l}\text { Patho- } \\
\text { genicityd }\end{array}$} & \multirow{2}{*}{$\begin{array}{l}V_{H} \text { gene } \\
\text { familye }\end{array}$} \\
\hline $\mathrm{mAb}$ & strain & & & $T$ & $E$ & $\mathrm{~B}$ & $\mathrm{R}$ & $H$ & & & \\
\hline 6 & Lew & Torpedo & $\lg G 1$ & +++ & +++ & +++ & +++ & +++ & $\alpha 67-76$ & AM, EAMG & Q52 \\
\hline 28 & Lew & Eel & $\operatorname{lgG} 2 a$ & ++ & +++ & + & + & & $\alpha 67-76$ & nd & J558 \\
\hline 35 & Lew & Eel & $\lg \mathrm{g}_{1}$ & +++ & +++ & +++ & +++ & +++ & $\alpha 37-85$ & AM, EAMG & Q52 \\
\hline 42 & Lou & Eel & $\operatorname{lgG} 2 a$ & +++ & +++ & ++ & + & - & $\alpha 67-76$ & EAMG & J558 \\
\hline 47 & Lou & Eel & $\operatorname{lgG} 2 a$ & +++ & +++ & - & - & - & $\alpha 67-76$ & nd & S107 \\
\hline 50 & Lou & $\mathrm{Eel}$ & $\lg G 1$ & +++ & +++ & + & + & nd & $\alpha 67-76$ & nd & S107 \\
\hline 65 & Lou & Bovine & $\lg G 1$ & + & - & +++ & - & + & $\mathrm{M} \mid \mathrm{R}$ & $A M$ & Q52 \\
\hline 198 & Lou & Human & $\lg G 2 a$ & +++ & +++ & +++ & +++ & +++ & $\alpha 67-76$ & $A M$ & Q52 \\
\hline 203 & Lou & Human & $\lg G 2 a$ & +++ & +++ & +++ & ++ & +++ & $\alpha 67-76$ & $A M$ & J606 \\
\hline 5 & & Torpedo & $\lg G 2 b$ & +++ & - & - & - & - & $\alpha 349-357$ & nd & J558 \\
\hline 8 & & T $\alpha$-subunit & $\operatorname{lgG} 2 a$ & +++ & ++ & + & + & - & $\alpha 366-372$ & nd & 3609 \\
\hline 19 & & Torpedo & $\operatorname{lgG} 2 b$ & +++ & - & - & - & - & $\alpha 348-362$ & nd & PC7183 \\
\hline 61 & Lou & Eel & $\operatorname{lgG} 2 a$ & + & + & + & + & & $\alpha 371-378$ & nd & J558 \\
\hline 111 & Lew & $\star$ & $\lg G 1$ & +++ & + & + & + & \pm & $\alpha 368-406$ & nd & PC7183 \\
\hline 142 & Lew & * & $\operatorname{lgG} 2 a$ & +++ & - & nd & - & - & $\alpha 353-359$ & nd & Vgam3.8 \\
\hline 147 & Lew & * & IgG2a & +++ & - & nd & - & - & $\alpha 364-370$ & nd & 3660 \\
\hline 149 & Lew & * & $\lg M$ & +++ & nd & - & - & \pm & $\alpha 339-346$ & nd & $\mathrm{Sta7}$ \\
\hline 153 & Lew & * & $\lg G 2 a$ & ++ & + & ++ & ++ & + & $\alpha 371-378$ & nd & PC.7183 \\
\hline 155 & Lew & * & $\lg G 2 a$ & ++ & + & + & + & + & $\alpha 371-378$ & $\cdot$ & PC.7183 \\
\hline 164 & Lew & * & $\lg G 2 a$ & + & - & - & + & + & $\alpha 371-379$ & nd & 5107 \\
\hline 187 & Lou & * & $\lg G 2 a$ & +++ & - & nd & - & nd & $\alpha 339-346$ & nd & $510 ?$ \\
\hline
\end{tabular}

Isotype, AChR cross-reactivity, fine specificity, pathogenicity and $V_{H}$ gene family utilization of rat anti-AChR mAbs. The source of AChR to which MAb is elicited: Torpedo: Torpedo californica AChR, Eel: electric eel AChR, Bovine: fetal bovine AChR. Human: denervated muscle AChR, Ta-subunit: the $\alpha$-subunit of Torpedo AChR, *: SDS denatured AChR + isolated AChR subunits. ${ }^{b}$ Cross-reaction with AChR from different species; T: Torpedo AChR, E: eel AChR, B: bovine AChR, R: rat AChR, H: human $A C h R .{ }^{C}$ Fine specificity determined by binding of mAbs to synthetic peptides of the $\alpha$ and $\beta$ subunits of the AChR; numbers denote aminoacid residues. ${ }^{d}$ The pathogenicity of anti-AChR mAbs determined by their ability to increase AChR curnover by antigenic modulation in vitro using muscle cell cultures, or induction of EAMG in vivo by passive transfer of anti-AChR MAb. AM: antigenic modulation in vitro, EAMG: $M A b$ inducing EAMG in vivo, nd: not done. "The $V_{H}$ gene family used by mAb determined with mouse $V_{H}$ gene family probes.

MAbs against closely adjacent or overlapping epitopes at the intracellular surface of AChR were encoded by 6 different $V_{H}$ gene families (J558: 2/12, S107: 3/12, PC7183: 4/12, Vgam3.8: 1/12, 3660: 1/12, 3609: 1/12). The panel of anti-AChR mAbs comprises mAbs that can induce experimental myasthenia gravis in vivo by passive transfer ( $m A b 6,35$ and 42) or increase AChR turnover in vitro by antigenic modulation (mAb 6, 35, 65, 198, 203). MAbs against intracellular epitopes are not pathogenic in vivo. Pathogenic mAbs were encoded by $V_{H}$ genes from the Q52 (4/6), J558 (1/6) and J606 (1/6) families. 


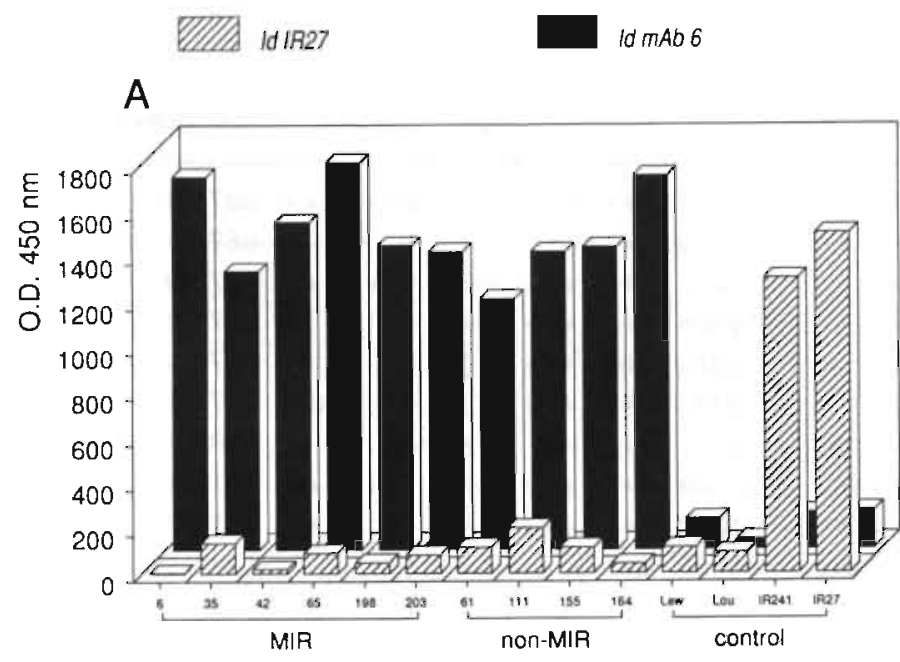

$\mathrm{B}$

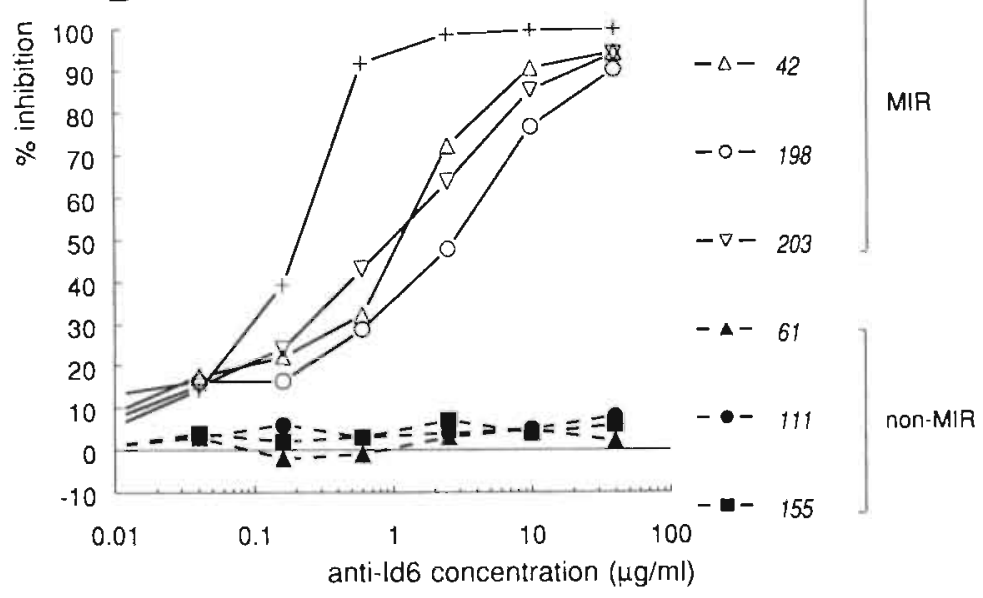

Figure 4: Rat anti-AChR mAbs express cross-reactive idiotopes

(A) Expression of a CRI was determined by binding of affinity purified polyclonal anti-idiotype antibodies to rat anti-AChR mAbs bound to microtiter plates. Anti-ld 6 is directed against the $C R l$ expressed by MAb 6 and binds to all anti-AChR mAbs but non of the controls. Control anti-ld IR27 only recognized CRI on rat myeloma protein IR27 and IR241. Lew: polyclonal lewis IgG, Lou: polyclonal louvain IgG.

(B) CRI determinants associated with the antigen binding site were detected by a solidphase antigen binding inhibition assay. Anti-AChR mAbs bound to microtiter plates were incubated with increasing amounts of anti-ld 6 prior to incubation with ${ }^{125 /-\alpha-B T-A C h R}$. The binding to anti-MIR MAbs can be inhibited by anti-ld 6 . The binding of ${ }^{125} /-\alpha-B T-A C h R$ to anti-AChR mAbs against intracellular located epitopes of AChR was not inhibited by anti-ld 6 . 


\section{$V_{H}$ gene family utilization in relation to idiotype expression}

Expression of a cross-reactive idiotype (CRI) by rat anti-AChR mAbs was determined for a panel of mAbs directed to the MIR or intracellular epitopes. All tested anti-AChR mAbs but non of the controls expressed a CRI as was demonstrated by binding of polyclonal anti-idiotype (anti-ld) antibodies raised against mAb 6 (fig 4A). None of the anti-AChR mAbs bound to a control anti-ld raised against rat myeloma protein IR27. Furthermore, it was demonstrated that only anti-MIR mAbs share idiotypic determinants associated with the antigen combining site. The binding of Torpedo AChR to anti-MIR mAbs was inhibited almost completely by anti-ld 6 . The binding of $A C h R$ to $m A b s$ recognizing intracellular epitopes distinct from the MIR was not inhibited by anti-Id 6 (fig 4B). The mAbs tested for expression of a CRI were encoded by the Q52, J558, J606, S107, and PC7183 $V_{H}$ gene families. No relation between expression of a $\mathrm{CRI}$ and utilization of a particular $\mathrm{V}_{\mathrm{H}}$ gene family could be demonstrated.

\section{DISCUSSION}

In this study the diversity of $V_{H}$ genes encoding rat anti-AChR mAbs was determined. The $V_{H}$ gene family utilization of anti-AChR mAbs directed against the MIR or intracellular epitopes on AChR was analyzed using mouse $V_{H}$ gene family probes. $V_{H}$ gene family utilization by a panel of 21 rat anti-AChR mAbs revealed that these mAbs are encoded by $V_{H}$ genes from 8 different families. Thus, $V_{H}$ genes expressed by rat $B$ cell hybridomas can be identified by mouse $V_{H}$ gene family probes. Messenger RNA transcripts of the Q52, PC7183 and J606 families were previously demonstrated in different rat mAbs against tubular basement membrane and the neuropeptide substance $P(20,21)$. Furthermore, members of the $S 107 \mathrm{~V}_{H}$ gene family were demonstrated in rat anti-phosphorylcholine antibodies (22). These results indicate that $V_{H}$ gene families analogous to mouse $V_{H}$ gene families exist in the rat.

In order to investigate the $V_{H}$ gene family utilization of rat anti-AChR mAbs it was necessary to characterize the number and complexity of $V_{H}$ gene families in the rat. The Ig $V_{H}$ gene locus has already been exstensively characterized in the mouse (13). Using the mouse $V_{H}$ gene family specific probes it was shown that rat $V_{H}$ gene families homologous to 11 out of 12 known mouse $V_{H}$ gene families exist in the rat, indicating that much resemblance between the rat and mouse $\lg V_{H}$ gene loci exists. Although some families are similar in complexity in mouse and rat, some rat families are expanded whereas others are contracted compared to the complexity of the mouse $V_{H}$ gene families. Homologous but unequal recombination between genes of the same family probably leads to expansion of a $V_{H}$ gene family whereas unequal recombination between genes of different families leads to contraction of the recombining $V_{H}$ gene families (23). The relative position of the rat $V_{H}$ gene families on chromosome 6 in the rat is still unkown 
The $V_{H}$ gene family utilization of rat anti-AChR mAbs was compared to the complexity of the rat $V_{H}$ gene families and did not follow a stochastic distribution over the different families, indicating that a non-random selection of $V_{H}$ genes has taken place. Especially the $S 107$ family was overrepresented whereas $V_{H}$ genes from the X24 were not expressed by anti-AChR mAbs in this panel. Utilization of $V_{H}$ genes from the $S 107$ family was however not related to a particular mAb fine specificity.

Anti-AChR mAbs with pathogenic potential in vivo or in vitro were most frequently encoded by $V_{H}$ genes from the Q52 family, whereas non pathogenic mAbs against intracellular epitopes were most frequently encoded by $V_{H}$ genes from the PC7183 family.

Murine autoantibodies of various specificities were found to be encoded by a restricted number of $V_{H}$ genes in particular from the PC7183 and Q52 families (10). Furthermore, hybridomas selected by $\mathrm{PC} 7183 \mathrm{~V}_{\mathrm{H}}$ gene expression produce autoreactive antibodies at a high frequency (11). Therefore, it was concluded that autoimmune disease may be related to a defective control of $V_{H}$ gene expression (12). The kind of $V_{H}$ gene family restriction found among rat anti-AChR mAbs is more likely to be related to structural requirements for the generation of particular binding sites than an indication for a possible defect in $V_{H}$ gene usage. Genetic restriction of $V_{H}$ genes was found to be common among antibodies against defined haptens but has also been observed in antibody responses to epitopes on complex antigens $(24,25)$. However, mAbs against the MIR are only partially restricted to the Q52 family and were also encoded by at least 3 other $V_{H}$ gene families. This may be a result of the heterogeneity among anti-MiR mAbs which were demonstrated to interact with different combinations of residues within the sequence $\alpha 67-76(26,27)$.

The presence of framework associated cross-reactive idiotopes was demonstrated on mAbs of different fine specificity whereas paratope related idiotopes were only demonstrated on MIR specific mAbs. Expression of a CRI was not related to a particular $V_{H}$ gene family utilization. Expression of a CRI by all tested anti-AChR mAbs indicate some form of shared determinants and one might expect a restricted $V_{H}$ gene usage $(28,29,30)$. However, apparently sharing of idiotopes can be found among mAbs of different specificities and encoded by different $V_{H}$ gene segments $(10,31,32)$. A definitive conclusion whether expression of $C R 1$ is derived from conformity in the tertiar structure or similarities in primary structure can only be made by assessment of the DNA sequence of the $V_{H}$ and $V_{L}$ genes encoding these mAbs.

\section{Acknowledgements}

We would like to thank Mieke Henfling for excellent laboratory assistance, and the Beatrix foundation for financial support 


\section{REFERENCES}

1 Lennon VA, Lindstrom JM, Seybold ME. (1975) Experimental autoimmune myasthenia: a model of myasthenia gravis in rats and guinea pigs. J. Exp. Med. 141:1365-1375

2 Lindstrom JM, Shelton D, Fuji Y. (1988) Myasthenia gravis. Adv. Immunol. 42:233-284

3 Tzartos SJ, Lindstrom JM. (1980). Monoclonal antibodies used to probe acetylcholine receptor structure: localization of the main immunogenic region and detection of similarities between subunits. Proc. Nati. Acad. Sci. USA 77:755-759

4 Tzartos SJ, Rand DE, Einarson BL, Lindstrom JM. (1981). Mapping of the surface structures of Electrophorus acetylcholine receptor using monoclonal antibodies. J. Blol. Chem. 256:8635-8645

5 Tzartos SJ, Lageberg L, Hochschwender S, Swanson LW, Lindstrom JM. (1986). Characteristics of monoclonal antibodies to denatured Torpedo and to native calf acetylcholine receptors. Species, subunit and region specificity. J. Neuroimmunol. 10:235-253

6 Kordossi AA, Tzartos SJ. (1989). Monoclonal antibodies against the main immunogenic region of the acetylcholine receptor. Mapping the intact molecule. J. Neurol. 23:35-40

7 Tzartos SJ, Sophianos D, Efthimiadis A. (1985). Role of the main immunogenic region of the acetylcholine receptor in myasthenia gravis. An Fab monoclonal antibody protects against antigenic modulation by human sera. J. Immunol. 134:2343-2349

8 Tzartos SJ, Powitz S. (1986). Decrease in acetylcholine-receptor content of human myotube cultures mediated by monoclonal antibodies to $\alpha, \beta$ and $\gamma$ subunits. FEBS Lett. 196:91-95

9 Tzartos SJ, Hochschwender S, Vasquez P, Lindstrom J. (1987). Passive transfer of experimental autoimmune myasthenia gravis by monclonal antibodies to the main immunogenic region of the acetylcholine receptor. J. Neuroimmunol. 15:185-194

10 Monestier M, Manheimer-Lory A, Bellon B, Painter C, Dang H, Talal N, Zannetti M, Schwartz R, Pisetsky D, Kuppers R, Rose N, Brochier J, Klaresog L, Holmdahl R, Erlanger $B$, Alt F, Bona C. (1986). Shared idiotopes and restricted immunoglobulin variable region heavy chain genes characterize murine autoantibodies of various specificities. J. Clin. Invest. 78:753-759

11 Bellon B, Manheimer-Lory A, Monestier M, Dimitriu-Bona A, Alt F, Bona C. (1987). High frequency of autoantibodies bearing cross-reactive idiotopes among hybridomas using $V_{H} 7183$ genes prepared from normal and autoimmune murine strains. J. Clin. Invest. 79:1044-1053

12 Stevenson FK. (1986). Idiotypes and disease. Immunol. Today 7:287-288

13 Brodeur PH, Osman GE, Mackle JJ, Lalor TM. (1988). The organization of the mouse Igh- $V$ locus. Dispersion, interspersion, and the evolution of $V_{H}$ gene family clusters. J. Exp. Med. 168:2261-2278

14 van Dongen JJM, Wolvers-Tettero JJM. (1991). Analysis of immunoglobulin and T cell receptor genes. Part I: Basic and technical aspects. Clin. Chim. Acta. 198:1-91

15 Bos NA, Meeuwsen CG. (1989). B cell repertoire in adult antigen-free and conventional neonatal Balb/c mice. I. Preferential utilization of the $\mathrm{C}_{H}$ proximal $\mathrm{V}_{\mathrm{H}}$ gene family $\mathrm{PC} 7183$. Eur. J. Immunol. 19:1811-1815

16 Meek K, Rathburn G, Reiniger L, Jaton JC, Kofler R, Tucker PW, Capra JD. (1990). Organization of the murine immunoglobulin $V_{H}$ complex: placement of two new $V_{H}$ gene families $\left(V_{H} 10\right.$ and $\left.V_{H} 11\right)$ and analysis of $V_{H}$ family clustering and interdigitation. Mol. immunol. 27:1073-1081

17 Verschuuren JJGM, Graus YMF, Tzartos S, Van Breda Vriesman PJC, De Baets MH. (1991). Paratope- and framework- related cross-reactive idiotopes on anti-acetylcholine receptor antibodies. J. Immunol. 146:941-948

18 Sambrook J, Fritsch E, Maniatis T. (1989). Molecular cloning: A laboratory manual (Cold Spring Harbor Laboratory, Cold Spring Harbor, NY). pp. 7.12-7.15 
19 Stastistics at square one. (1978) TDV Swinscow Ed, Britisch Medical Association, London.

20 Clayman MD, Sun MJ, Michaud L, Brill-Dashoff J, Riblet R, Neilson EG. (1988). Clonotypic heterogeneity in experimental interstitial nephritis. Restricted specificity of the anti-tubular basement membrane $B$ cell repertoire is associated with a disease-modifying cross-reactive idiotype. J. Exp. Med. 167:1296-1312

21 Piccioli P, Ruberti F, Biocca S, Di Luzio A, Werge TM, Bradbury A, Cattaneo A. (1991). Neuroantibodies: Molecular cloning of a monoclonal antibody against substance $P$ for expression in the central nervous system. Proc. Natl. Acad. Sci. USA. 88:5611-5615

22 Perlmutter RM, Schroeder HW jr. (1986). Molecular evolution of the T15 $\mathrm{V}_{\mathrm{H}}$ gene family. In: Evolution and vertebrate immunity. Kelsoe $G$, and Schultze D, Eds. Texas university press, Austen. p. 149-162

23 Krawinkel U, Christoph T, Blankenstein T. (1989). Organization of the $\mathrm{Ig} \mathrm{V}_{H}$ locus in mice and humans. Immunol. Today. 10:339-344

24 Clarke SH, Huppi CK, Ruenzinsky D, Staudt L, Gerhard W, Weigert M. (1985). Inter- and Intra- clonal diversity in the antibody response to influenza hemagglutinin. J. Exp. Med. 161:687-704

25 Caton AJ, Brownlee GG, Staudt LM, Gerhard W. (1986). Structural and functional implications of a restricted antibody response to a defined antigenic region of the influenza virus hemagglutinin. EMBO J. 5:1557-1587

26 Bellone M, Tang F, Milius R, Conti-Tronconi BM. (1989). The main immunogenic region of the nicotinic acetylcholine receptor. Identification of aminoacid residues interacting with different antibodies. J. Immunol. 143:3568-3579

27 Tzartos SJ, Loutrari HV, Tang F, Kokla A, Walgrave SL, Milius RP, Conti-Tronconi BM. (1990). Main immunogenic region of Torpedo electroplax and human muscle acetylcholine receptor: localization and microheterogeneity revealed by the use of synthetic peptides. J. Neurochem. 54:51-61

28 Rauch J, Murphy E, Roths JB, Stollar D, Schwartz RS. (1982). A high frequency idiotypic marker of anti-DNA autoantibodies in MRL-ipr/lpr mice. J. Immunol. 129:236-241

29 Marion TN, Lawton AR, Kearney JF, Briles DE. (1982). Anti-DNA autoantibodies in (NZBXNZW)F1 mice are clonally heterogeneous, but the majority share a common idiotype. J. Immunol. 128:668-673

30 Hahn BH, Ebling FM. (1987). Idiotype restriction in murine lupus; high frequency of three public idiotypes on serum IgG in nephritic NZB/NZW F1 mice. J. Immunol. 138:21102118

31 Painter C, Monestier M, Bini B, Bona CA. (1986). Functional and molecular studies of $V$ genes expressed in autoantibodies. Immunol. Rev. 94:75-98

32 Moran TM, Monestier M, Lai ACK, Norton G, Reale MA, Thompson MA, Schulman, Riblet $R$, Bona C. (1987). Characterization of variable-region genes and shared cross-reactive idiotypes of antibodies specific for antigens of various influenza viruses. Viral Immunol. $1: 1-12$ 


\section{Summary and general discussion}

The immune system is able to recognize and eliminate virtually all foreign organisms invading the body. In contrast, a state of unresponsiveness towards self is maintained by the immune system. In some instances the unresponsiveness towards self constituents is abrogated resulting in an autoimmune response destroying the body's own structures. Myasthenia gravis (MG) is an autoimmune disease in which autoantibodies develop against a receptor protein involved in the signal transmission from the nerve to the muscle. The neurotransmitter acetylcholine is released from the nerve ending upon nerve stimulation and binds to the acetylcholine receptor $(A C h R)$ at the muscle membrane, which subsequently activates the muscle to contract. In MG the number of available functional AChR molecules is diminished by autoantibody mediated degradation of these receptors. Signal transmission is therefore impaired, resulting in muscle weakness and paralysis. MG is caused by autoantibodies as was demonstrated by transfer of antibodies from patients to experimental animals or placental transfer from mother to child. The events that initiate this autoimmune response in MG are still unkown. Much of the information about myasthenia gravis is obtained from an experimental model for this disease in which animals are immunized with purified AChR. In this thesis the experimental autoimmune model was studied to gain information about the nature of the immune response directed against the AChR on the one hand, and on the other hand the role of the target organ in determining the severity of the disease. Therefore two main subjects were addressed in this thesis. I The contribution of immunological and non-immunological factors involved in age related resistance to experimental autoimmune myasthenia gravis (EAMG). II The specificity and genetic diversity of anti-AChR antibodies, isolated from mice strains which have high or low susceptibility for EAMG, were investigated.

The first chapter contains a review of current facts about the AChR, MG and EAMG. The autoantigen in MG is the AChR which is localized at the motor nerve endplate in high density. Much of the information about this transmembrane receptor protein has been revealed by gene sequence analysis and functional studies. The AChR is composed of five subunits arranged around a central ion channel. The relevant antigenic determinants recognized by the immune system have been characterized for anti-AChR antibodies and AChR specific $T$ lymphocytes. Several antigenic determinants recognized by antibodies ( $B$ lymphocyte epitopes) have been characterized by binding studies of anti-AChR monoclonal antibodies ( $\mathrm{MAb}$ ) to overlapping synthetic peptides of AChR subunits. The majority of anti-AChR antibodies from MG patients or experimental animals with EAMG are directed to a fragment of 10 aminoacids on the $\alpha$-subunit called the main immunogenic region (MIR). AChR specific $T$ lymphocytes recognize multiple short peptide sequences from the ex- 
tracellular, transmembrane and intracellular domains of the AChR. Determinants recognized by $T$ lymphocytes are mostly different from those recognized by antibody.

A description of MG is given and possible aetiological factors including molecular mimicry, drug induced transient loss of tolerance, and the role of the thymus are discussed. Detailed information is given about the EAMG model, since all experiments in this thesis are performed in this model. A chronic form of EAMG can be induced in several animal species by immunization with AChR isolated from electric organs of the electric ray Torpedo californica. EAMG can also be induced by some (poly)peptide fragments of the $\alpha$-subunit of AChR or passive transfer of anti-AChR antibodies. EAMG mirrors MG in several aspect except for the thymic abnormalities associated with MG. The mechanisms of the autoimmune attack against the AChR and the pathology observed at the motor nerve endplates is identical for MG and EAMG. Three major immunopathological mechanisms of AChR degradation by autoantibodies result in a loss of functional AChRs in MG and EAMG. I Antibodies bound to the AChR induce antigenic modulation of AChR molecules through cross-linking by antibody, resulting in an increased internalization and degradation. II Complement mediated destruction of muscle membrane at the motor nerve endplate. III Interference with AChR function by blocking acetylcholine binding or the ion channel function of the AChR.

Chapter 2 describes the observation that aged rats are resistant to the induction of both chronic and acute passive transfer EAMG. The mechanisms underlying this age related resistance were investigated in detail using the passive transfer model, in which young and aged rats were injected with a mAb directed against the MIR of the AChR. Passive transfer of this anti-AChR mAb induced severe weight loss and electromyographic abnormalities in young but not in aged rats. In addition, aged rats in contrast to young rats did not show loss of AChRs. Possible mechanisms responsible for resistance to EAMG were evaluated. Uptake of intraperitoneal injected mAb into the circulation was similar in both age groups. However, 48 hours after injection the concentration of $\mathrm{mAb}$ declined more rapidly in young compared to aged rats indicating a higher consumption of mAb in young rats. This could not be explained by a difference in antibody clearance from the circulation since both age groups showed a comparable clearance of immunoglobulin $\mathrm{G}$. The significantly larger decline in mAb concentration in the circulation of young rats suggested that the AChR degradation by antigenic modulation is higher in young rats, consuming more antibody. Complement component $\mathrm{C} 3$ was demonstrated at endplates in muscle biopsies of both age groups indicating that complement mediated lysis of the postsynaptic membrane occurs in both age groups. However, infiltrating macrophages were only found at the endplates and in necrotic muscle fibers of young animals.

In summary these results suggest that the age related resistance against induction of EAMG is attributable to resistance of the AChR at the postsynaptic membrane (target organ of the autoimmune response) against autoantibody mediated degradation. One of the mechanisms underlying this observed resistance may be the absence of AChR degradation due to cross-linking of adjacent AChR molecules by antibody. At the normal density of AChR molecules at the postsynaptic membrane, 


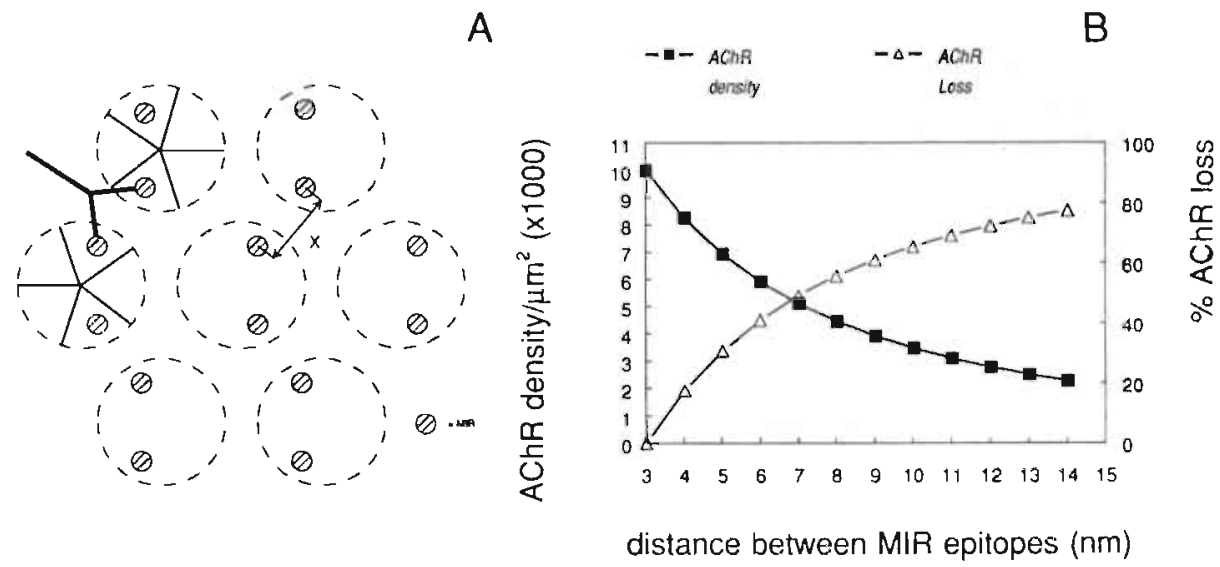

Figure 1: A: Cross-linking of AChR molecules by antibody.

The presumed arrangement of AChR molecules at the endplate at a density of 10000 molecules/Am². At this AChR density, the distance between adjacent MIR epitopes is $\pm 3 \mathrm{~nm}$ and anti-MIR antibody is able to cross-link AChR molecules. $X$ : the distance between adjacent MIR epitopes.

$\mathrm{B}$ : The distance between adjacent MIR epitopes is related to the AChR density.

The distance between adjacent MIR epitopes is calculated in relation to AChR density. An AChR density of 10000 molecules $4 \mathrm{~mm}^{2}$ is considered physiological. A decrease in AChR density is also expressed as percentage AChR loss (right abscissa). At decreasing AChR densities, the distance between MIR epitopes increases until $\pm 12 \mathrm{~nm}$ at which the antibody is no longer able to simultaneously bind two MIR epitopes and cross-linking is no longer possible.

eptitopes (like the MIR) on the $\alpha$-subunits of adjacent AChR molecules are in close proximity $( \pm 3 \mathrm{~nm})$, which enable anti-AChR antibodies to cross-link these AChR molecules and accelerate their internalization and breakdown (fig. 1a). When the AChR density decreases the distance between adjacent epitopes increases (fig. 1b). At distances larger than $12 \mathrm{~nm}$ the antibodies are no longer able to cross-link AChRs and AChR degradation by antigenic modulation is averted. The maximum distance of $12 \mathrm{~nm}$ between adjacent epitopes is attained at a decrease of the AChR density of about $70 \%$ (fig. 1b). It was demonstrated in rats that the AChR density at the endplate diminishes up to $80 \%$ with increasing age (1). Interestingly, the maximum AChR loss observed in rats with chronic EAMG seldom exceeds $70 \%$ $(2,3)$. Moreover, rats that become resistent to a second episode of passive transfer EAMG show more than $60 \%$ AChR loss, and regain susceptible to EAMG when the AChR density increases again (4). Therefore, the AChR density is apparently important for antigenic modulation to take place and the AChR density at the aged endplate is possibly below a critical level to accomplish AChR degradation by antigenic modulation. In future studies the AChR degradation rate in vivo will be measured in young and aged rats during passive transfer EAMG, to evalute this hypothesis.

Another possible mechanism may be an increased rigidity of the postsynaptic membrane in aged rats due to a different lipid composition. A rigid membrane could impede internalization of the AChR-antibody complex. The influence of the lipid composition on the rate of $A C h R$ degradation shall be investigated by manipulation 
of the membrane lipid contents by treatment with phosphatidylcholine/sphingomyelin containing liposomes which were demonstrated to reverse the lipid composition of rat myocytes from "aged" to "young" (5).

Finally, a possible defect of macrophage function in aged animals (6), that could influence the susceptibility for EAMG can not be ruled out. It remains to be determined what te actual contribution of these cells is to the pathophysiology of the disease.

Chapter 3 introduces the second part of this thesis and gives an overview of the immunoglobulin structure and the generation of antibody diversity. Antibodies are capable of specifically recognizing virtually any antigenic determinant. The immunoglobulin molecule is composed of a heavy-and light chain. Each heavy-and light chain is composed of a constant, and a variable region $\left(V_{H}\right.$ and $\left.V_{L}\right)$ which forms a large part of the antigen binding site. The genetic elements encoding the variable regions are grouped in families of related $V$ genes. The complexity (size) and the organization of the $V_{H}$ gene families are discussed. It was previously postulated that murine autoantibodies are frequently encoded by $V_{H}$ genes from a restricted number of families. A review is given about current literature concerning the utilization of $V_{H}$ genes in autoantibodies from normal or autoimmune prone animals. The immunoglobulin molecule itself is a protein, bearing antigenic determinants. The antigenic determinants associated with the variable region of an antibody molecule together form the idiotype, that can be recognized by other antibodies (anti-idotypes). Antibodies of different specificity can share a cross-reactive or common idiotype that suggests that these antibodies are encoded by related variable region genes. The structural basis for cross-reactive idiotypes is discussed.

Chapter 4 describes the production and characterization of mAbs obtained from two mouse strains with high (C57bl/6) and low (Balb/c) susceptibility for the induction of EAMG. MAbs directed against several extra- and intracellular located epitopes including mAbs directed against the MIR, and the $\alpha$-bungarotoxin/acetylcholine binding site ( $\alpha-B T)$, were isolated from both mouse strains. The relative frequencies of hybridomas cross-reactive with autologous mouse AChR, or directed against the MIR and the $\alpha$-BT binding site were higher in susceptible C57bl/6 than in low susceptible Balb/c mice, suggesting a possible difference in antibody repertoire. This observed difference in the anti-AChR antibody repertoire was evaluated in the polyclonal anti-AChR response upon induction of EAMG by immunization with AChR. The mean antibody titer against mouse AChR was similar in both mouse strains. In addition, the concentrations of antibodies directed against the MIR and $\alpha$-BT binding site in the sera of both mouse strains were found to be similar after secondary immunization with AChR. Moreover, the concentrations of anti-MIR and anti- $\alpha$-BT antibodies in C57bl/6 mice with or without clinical signs, were found to be comparable. These results indicate that strain specific differences in disease susceptibility in murine EAMG are not related to differences in the overall concentration of antibodies against the MIR or $\alpha$-BT/cholinergic binding site. Fine specificity, affinity and the combined effect of several antibody specificities binding to the AChR at the same time determine the net effect on the AChR function and 
degradation rate. This probably explains the poor correlation of the total anti-AChR antibody titer with the clinical state; pathogenic antibodies may form a variable subset of the total anti-AChR antibody pool. Furthermore, several physiological factors like the AChR reserve and the acetylcholine quantal content, which together determine the safety margin of neuromuscular transmission, influence the outcome of the disease.

In Chapter 5 the genetic diversity of heavy chain variable region genes encoding anti-AChR mAbs was determined. The $V_{H}$ genes are grouped in families of homologous genes. To investigate the diversity of $V_{H}$ genes encoding anti-AChR mAbs in the EAMG model, we determined the $V_{H}$ gene family usage of 65 anti-AChR mAbs and 20 anti-KLH mAbs isolated from susceptible $\mathrm{C} 57 \mathrm{bl} / 6$ and low susceptible Balb/c mice, by RNA slot-blot analysis using probes specific for nine $V_{H}$ gene families. Anti-AChR mAbs were found to be encoded by $V_{H}$ genes from at least 6 different families. The $V_{H}$ gene family usage of anti-AChR mAbs approached a stochastic distribution over the different $V_{H}$ gene families in which the frequency of utilization of a $V_{H}$ gene from a particular family is proportional to the size of that family. Significant deviations from this distribution were found for the $J 606$ and Vgam3.8 families. $V_{H}$ genes from the $J 606$ family were not found in any of the tested anti-AChR mAbs, while the Vgam3.8 family was markedly overrepresented in mAbs directed to the $\alpha$-BT binding site. In contrast, no preferential $V_{H}$ gene familiy was utilized to encode mAbs directed to the MIR.

Anti-AChR mAbs only specific for Torpedo AChR and mAbs recognizing both Torpedo and mouse AChR showed no significant difference in $V_{H}$ gene family utilization. In addition, there was no significant difference in $V_{H}$ gene family utilization between anti-AChR mAbs obtained from high and low susceptible mice. Therefore, differences in disease susceptibility could not be attributed to a deviant $V_{H}$ gene family usage.

Anti-AChR antibodies sharing a cross-reactive idiotype (CRI) were found to be encoded by $V_{H}$ genes from at least 6 different families suggesting no direct relation between expression of a CRI and the utilization of a restricted number of different $V_{H}$ genes. Taken together, these results indicate that anti-AChR antibodies are encoded by multiple different $V_{H}$ genes and no bias in $V_{H}$ gene family utilization as reported for other autoantibodies, could be demonstrated for anti-AChR mAbs.

In addition to mouse anti-AChR mAbs, the $V_{H}$ gene family utilization was determined of a panel of rat anti-AChR mAbs with well defined fine specificity and pathogenicity. In Chapter 6 the $V_{H}$ gene family utilization of rat anti-AChR mAbs was determined using probes for known $V_{H}$ gene families in the mouse. Slot-blot analysis of 21 rat anti-AChR mAbs revealed that these mAbs are encoded by $V_{H}$ genies from at least. 8 different families. It was verified whether $V_{H}$ gene families analogous to the mouse $V_{H}$ gene families exist in the rat. Southern blot hybridization of DNA of different rat strains with probes for 11 mouse $V_{H}$ gene families confirmed the existance of analogous $V_{H}$ gene families in the rat. The complexity of these rat $V_{H}$ gene families was found to be different from analogous families in the mouse; the $J 558$ family was smaller whereas the $P C 7183, X 24, Q 52, V_{H} 10$, and $V_{H} 11$ families were larger than in the mouse. 
The $V_{H}$ genes encoding rat anti-AChR mAbs did not follow a stochastic distribution over the different $V_{H}$ gene families, due to overrepresentation of members of the S107 family and underrepresentation of the $X 24 V_{H}$ gene family. The panel of rat anti-AChR mAbs consists of anti-MIR mAbs and mAbs against overlapping epitopes on the intracellular surface of the AChR. A partial correlation between $V_{H}$ gene family utilization and mAb fine specificity was found. MAbs against the MIR showing pathogenic potential in vivo or in vitro were most frequently encoded by $V_{H}$ genes from the Q52 family, whereas non pathogenic mAbs against intracellular epitopes were most frequently encoded by $V_{H}$ genes from the PC7183 family. The frequent utilization of $V_{H}$ genes from a particular $V_{H}$ gene family suggests the use of related $V_{H}$ gene sequences to encode these antibodies of related fine specificity.

Rat anti-AChR mAbs were shown to express a CRI consisting of framework associated cross-reactive idiotopes shared by all tested anti-AChR mAbs and paratope associated cross-reactive idiotopes shared only by anti-MIR mAbs. Both anti-AChR mAbs expressing framework- as well as paratope associated cross-reactive idiotopes were encoded by $V_{H}$ genes from several different $V_{H}$ gene families. Taken together, the $V_{H}$ gene family utilization of rat anti-AChR mAbs showed that probably many different $V_{H}$ genes can be used to encode anti-AChR antibodies. This is an unexpected finding in the light of the fact that a large fraction of the anti-AChR antibodies in MG and EAMG are directed against the MIR, which comprises a small group of epitopes. Furthermore, anti-AChR antibodies express a $\mathrm{CR}$ that suggests some form of structural resemblance between these antibodies. Expression of a CRI idiotype by anti-AChR mAbs may be related to the $V_{L}$ chain; sequence analysis of the $V_{L}$ chain of 4 anti-MIR mAbs revealed an amino acid homology of more than $90 \%$ (Dr. S.J. Tzartos, personal communication). Furthermore, anti-AChR mAbs could be encoded by highly homologous diversity or joining gene segments. In future studies the sequence of anti-AChR mAbs will be determined to further reveal structural similarities between anti-AChR antibodies.

Structural resemblance between immune receptors like antibody and the $T$ cell receptor which are specific for $A C h R$ reactive $B$ or $T$ lymphocytes may provide a tool for manipulating the autoimmune response against the $\operatorname{AChR}(7,8)$.

In addition, sequence analysis of anti-AChR antibodies may provide information about the origin of these autoantibodies; are these autoantibody sequences part of the germline encoded repertoire ? $(9,10)$. Furthermore, comparison of the antiAChR antibody sequences with known sequences of antibodies against exogenous antigens, may reveal information about the possibility that anti-AChR antibodies evolve from such non-pathogenic antibodies by limited somatic mutation (11). 


\section{Samenvatting en algemene discussie}

Het immuunsysteem is in staat vrijwel elk lichaamsvreemd organisme, dat het lichaam binnendringt, te herkennen en te elimineren. In tegenstelling tot deze reactiviteit met lichaamsvreemde structuren, reageert het immuunsysteem niet met eigen structuren. In sommige gevallen wordt deze tolerantie voor 'eigen' opgeheven en worden lichaamseigen structuren afgebroken. Myasthenia gravis (MG) is een auto-immuun ziekte, waarbij zich auto-antilichamen ontwikkelen gericht tegen een receptor-eiwit, dat betrokken is bij de overdracht van zenuwsignalen van de zenuw naar de spier. Bij stimulatie van de zenuw wordt de neurotransmitter acetylcholine aan het zenuwuiteinde vrijgemaakt en bindt aan de acetylcholine receptor (AChR), gelegen in de spiermembraan welke vervolgens de spier aanzet tot samentrekking. Bij MG wordt het aantal beschikbare functionele AChR moleculen verminderd door auto-antilichaam gemedieerde afbraak van deze receptoren. Hierdoor treedt een verslechtering op van de signaal overdracht, wat resulteert in spierzwakte en verlamming. Dat MG veroorzaakt wordt door auto-antilichamen is aangetoond door passieve overdracht van antilichamen afkomstig van MG patiënten naar proefdieren, of door overdracht van moeder op kind via de placenta. De oorzaak voor het onstaan van deze auto-immuun respons bij MG is nog niet bekend. Veel van de informatie over MG is verkregen met behulp van een proefdiermodel voor deze ziekte, waarbij proefdieren worden geïmmuniseerd met gezuiverde AChR. Enerziids wordt in dit proefschrift het proefdier model bestudeerd, om meer informatie te verkrijgen over de aard van de auto-immuun respons gericht tegen de AChR en anderzijds om informatie te verkrijgen over de rol die het doelorgaan speelt bij de ernst van de ziekte.

Dit proefschrift is daarom in twee hoofdonderwerpen onder te verdelen. I de bijdrage van immunologische en niet immunologische factoren betrokken bij leeftijds afhankelijke resistentie tegen experimentele auto-immuun maysthenia gravis (EAMG). II De specificiteit en de genetische diversiteit van anti-AChR antilichamen, verkregen uit muizen met hoge en lage gevoeligheid voor EAMG.

Het eerste hoofdstuk omvat een overzicht van recente gegevens met betrekking tot de AChR, MG en EAMG.

Het auto-antigeen bij MG is de AChR, die in hoge dichtheid gelokaliseerd is ter hoogte van de motor-eindplaat. Veel van de informatie over dit transmembraan receptor-eiwit is verkregen door analyse van de $A C h R$ coderende genen en door functionele studies. De AChR is samengesteld uit vijf subunits gegroepeerd rond een centraal ion kanaal. De belangrijkste antigene determinanten die herkend worden door het immuunsysteem, zijn gekarakteriseerd voor zowel anti-AChR antilichamen als AChR specifieke T lymfocyten. Verscheidene antigene determinanten die herkend worden door antilichamen (B lymfocyt epitopen), zijn bepaald door 
binding van anti-AChR monoklonale antilichamen (mAb) aan overlappende synthetische peptiden van AChR subunits. Het grootste deel van de anti-AChR antilichamen van MG patiënten of proefdieren met EAMG, zijn gericht tegen een fragment van 10 aminozuren gelegen op de $\alpha$-subunit, genaamd 'main immunogenic region' (MIR). AChR specifieke $T$ lymfocyten herkennen verscheidene korte peptiden afkomstig van extracellulaire, transmembraan en intracellulaire gedeelten van de AChR. Determinanten die herkend worden door T lymfocyten, zijn vaak verschillend van die welke herkend worden door antilichamen.

Er wordt een beschrijving gegeven van $M G$ en mogelijke factoren, die een rol spelen bij het onstaan van de ziekte waaronder moleculaire mimicry, tijdelijke geneesmiddel geinduceerd verlies van tolerantie en de rol van de thymus. Het EAMG model wordt meer gedetailleerd beschreven, daar het experimentele werk van dit proefschrift in het EAMG model is uitgevoerd. Een chronische vorm van EAMG kan in verschillende diersoorten opgewekt worden d.m.v. immunisatie met AChR, afkomstig van de electrische organen van de sidderrog Torpedo californica. EAMG kan eveneens worden opgewekt door immunisatie met sommige (poly)peptiden van de $\alpha$-subunit van de AChR, of $d . m . v$. passieve overdracht van anti-AChR antilichamen. EAMG en MG vertonen veel overeenkomst, behalve wat betreft de thymus afwijkingen die geassocieerd zijn met humane MG. De mechanismen van de auto-immuun aanval gericht tegen de AChR en de pathologie van de motorische zenuw-eindplaat zijn identiek in MG en EAMG. De afbraak van functionele AChR door auto-antilichamen bij MG en EAMG wordt hoofdzakelijk veroorzaakt door drie immunopathologische mechanismen. I Antilichamen gebonden aan de AChR kunnen resulteren in antigene modulatie van AChR moleculen d.m.v. het koppelen van twee AChR moleculen door een antilichaam ("cross-linken"), waarna dit complex versneld wordt geïnternaliseerd en afgebroken. II Complement gemedieerde afbraak van de spiercelmembraan ter hoogte van de motorische zenuw-eindplaat. III Inhibitie van de receptor functie d.m.v. het blokkeren van de acetylcholine binding of de ion kanaal functie.

Hoofdstuk 2 beschrijt de observatie dat oude ratten resistent zijn tegen het opwekken van zowel chronische als acute EAMG d.m.v. passieve overdracht van anti-AChR antilichaam (passieve transfer EAMG). De mechanismen die aan deze leeftijds afhankelijke resistentie ten grondslag liggen werden in detail onderzocht, gebruik makend van het passieve transfer model, waarbij jonge en oude ratten werden geïnjecteerd met een mAb gericht tegen de MIR van de AChR. Passieve transfer van dit anti-AChR mAb induceerde ernstig gewichtsverlies en electromyographische afwijkingen bij jong volwassen ratten. Oude ratten vertoonden daarentegen geen klinische verschijnselen. Bovendien vertoonden oude ratten in tegenstelling tot jonge ratten geen verlies aan AChRs. Mogelijke mechanismen die ten grondslag liggen aan deze resistentie tegen EAMG werden nagegaan. De opname van intraperitoneaal geinjecteerd antilichaam in de bloedsomloop was vergelijkbaar in beide leeftijdsgroepen. Echter 48 uur na injectie, nam de concentratie van het mAb sneller af bij jonge ratten vergeleken met oude ratten, wat wees op een hoger verbruik van het mAb bij jonge ratten. Dit kon niet verklaard worden door een verschil in antilichaamklaring uit de bloedsomloop, daar beide leeftijdsgroepen een overeenkomstige klaring van immunoglobuline $G$ vertoonden. De significant grotere 
afname van de concentratie van het mAb in de bloedsomloop van jonge ratten suggereerde dat de afbraak van AChR d.m.v. antigene modulatie hoger is in jonge ratten, waardoor meer mAb werd verbruikt.

De C3 component van complement werd aangetoond ter hoogte van de eindplaat in spierbiopten afkomstig van beide leeftijdsgroepen, wat liet zien dat complement gemedieerde lysis van de postsynaptische membraan in beide leeftijdsgroepen optrad. Infiltrerende macrophagen werden echter enkel aangetoond bij eindplaten en in necrotische spiervezels van jonge dieren.

Samengevat suggereren deze resultaten dat de leeftijds afhankelijke resistentie tegen het opwekken van EAMG berust op resistentie van de AChR ter hoogte van de postsynaptische membraan (het doel orgaan van de auto-immuun respons), tegen auto-antilichaam gemedieerde afbraak. Een van de mechanismen die ten grondslag liggen aan deze resistentie zou kunnen zijn, het ontbreken van AChR degradatie door het koppelen van naburige AChR moleculen door antilichamen. Bij een normale AChR dichtheid ter hoogte van de eindplaat, zullen epitopen (zoals de MIR) gelegen op de $\alpha$-subunits van naburige AChR moleculen dicht bij elkaar liggen $( \pm 3 \mathrm{~nm})$, zodat anti-AChR antilichamen AChR moleculen kunnen koppelen en zodoende de internalisatie en afbraak kunnen versnellen (fig 1a). Als de AChR dichtheid afneemt zal de afstand tussen naburige epitopen toenemen (fig $1 \mathrm{~b}$ ). Wanneer de afstand groter wordt dan $12 \mathrm{~nm}$ zullen anti-AChR antilichamen niet langer in staat zijn om AChRs te kunnen koppelen waardoor antigene modulatie wordt voorkomen. Deze maximum afstand tussen naburige epitopen wordt bereikt wanneer de AChR dichtheid afneemt tot $\pm 70 \%$ (fig 1b). Aangetoond werd dat de AChR dichtheid ter hoogte van de eindplaat afneemt met $\pm 80 \%$ bij ratten met toenemende leeftijd (1). Opmerkelijk is bovendien dat het maximale verlies aan AChR waargenomen bij ratten met chronische EAMG zelden groter is dan $70 \%(2$, 3). Bovendien vertoonden ratten, die resistent waren tegen een tweede inductie van passieve transfer EAMG, meer dan $60 \%$ AChR verlies en werden hernieuwd gevoelig voor passieve transfer EAMG nadat de AChR dichtheid weer toenam (4). De AChR dichtheid is daarom blijkbaar belangrijk voor het optreden van antigene modulatie en mogelijkerwijs is de AChR dichtheid ter hoogte van de "oude" eindplaat beneden een kritische dichtheid, waarbij AChR afbraak door antigene modulatie niet meer mogelijk is. Deze hypothese zal worden nagegaan in een toekomstige studie waarbij de AChR afbraak in vivo zal worden gemeten bij jonge en oude ratten waarbij passieve transfer EAMG is opgewekt.

Een ander mogelijk mechanisme zou een verhoogde rigiditeit van de postsynaptische membraan bij oude ratten kunnen zijn, als gevolg van een veranderde lipide samenstelling. Een rigide membraan zou de internalisatie van AChR-antilichaamcomplexen kunnen bemoeilijken. De invloed van de lipide samenstelling op de afbraaksnelheid van AChR zal worden onderzocht d.m.v. manipulatie van het membraan lipide, door behandeling met fosfaditylcholine/sphingomyeline bevattende liposomen waarvan, is aangetoond dat deze de lipide samenstelling van rat myocyten kunnen omzetten van 'oud' naar 'jong' (5). Tenslotte kan de invloed van een mogelijk defect van de macrophagen bij oude dieren (6) op de gevoeligheid voor EAMG niet worden uitgesloten. De werkelijke bijdrage van deze cellen aan de pathofysiologie van de ziekte zal in toekomstig onderzoek worden bepaald. 
A

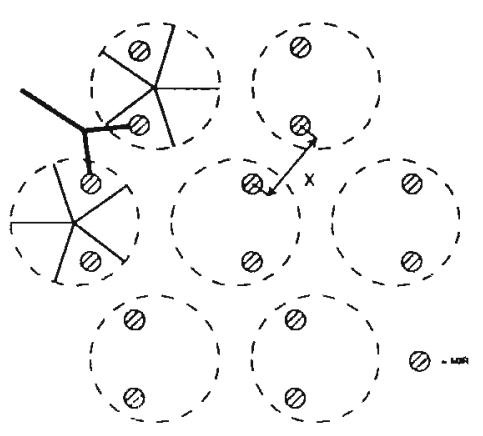

B

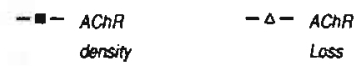

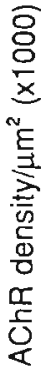

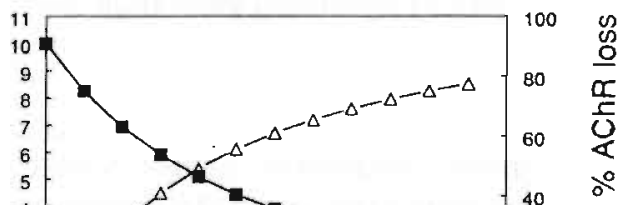

Figuur 1: A: Het koppelen van AChR moleculen door antilichaam.

De veronderstelde rangschikking van AChR moleculen ter hoogte van de eindplaat bij een dichtheid van 10000 moleculen/4m ${ }^{2}$. Bij deze AChR dichtheid is de afstand tussen naburige MIR epitopen \pm 3 $\mathrm{nm}$ en zijn anti-MIR antilichamen in staat AChR moleculen te koppelen. $X$ : de afstand tussen naburige MIR epitopen.

$B$ : De afstand tussen naburige MIR epitopen is gerelateerd aan de AChR dichtheid De alstand lussen naburige MIR epitopen werd berekend in relatie tot de AChR dichtheid. Een AChR dichtheid van 10000 moleculen $\mu \mathrm{m}^{2}$ werd beschouwd als fysiologisch. Een afname van de AChR dichtheid werd tevens uitgedrukt als percentage AChR verlies (rechter $Y$-as). Bijeen afnemende AChR dichtheid neemt de afstand tussen MIR epitopen toe tot $\pm 12 \mathrm{~nm}$ waarbij antilichaam niet langer in staat is om twee MIR epitopen simultaan te binden waardoor het koppelen van AChR moleculen niet meer mogellik is.

Hoofdstuk 3 vormt de introductie van het tweede deel van dit proefschrift en geeft een overzicht van de opbouw van het immunoglobuline molecuul en het genereren van antilichaam diversiteit. Antilichamen zijn in staat vrijwel elke denkbeeldige antigene determinant te herkennen. Het immunoglobuline molecuul is samengesteld uit een zware en een lichte keten. Een zware en lichte keten bestaan elk uit een constante en een variabele regio $\left(V_{H}\right.$ en $V_{L}$ ) welke het grootste gedeelte van de antigeen bindingsplaats vormt. De genetische elementen die voor de variabele regio coderen zijn gegroepeerd in families van verwante $V$ genen. De complexiteit (grootte) en de organisatie van deze $V_{H}$ gen families worden besproken. In voorgaande studies werd gepostuleerd, dat muize auto-antilichamen frequent worden gecodeerd door $V_{H}$ genen van een gerestricteerd aantal families. Er wordt een overzicht gegeven van recente literatuur betreffende het gebruik van $V_{H}$ genen in auto-antilichamen afkomstig van normale muizen en muizen met een auto-immuun predispositie.

Het immunoglobuline molecuul is opzichzelf een eiwit dat antigene determinanten draagt. De antigene determinanten geassocieerd met het variabele gedeelte van het antilichaam molecuul, vormen samen het idiotype dat herkend kan worden door andere antilichamen (anti-idiotype antilichamen). Antilichamen met verschillende specificiteit kunnen een kruisreactief of publiek idiotype delen wat suggereert dat 
deze antilichamen zijn gecodeerd door verwante variable regio genen. De structurele basis voor het voorkomen van een kruisreactief idiotype wordt besproken.

Hoofdstuk 4 beschrijft de produktie en karakterisering van monoclonale antilichamen verkregen van twee muizenstammen, welke een hoge (C57bl/6) en lage $(\mathrm{Balb} / \mathrm{c})$ gevoeligheid vertonen voor de inductie van EAMG. MAbs gericht tegen verscheidene extracellulair of intracellulair gelegen epitopen, waaronder mAbs gericht tegen de MIR en de $\alpha$-bungarotoxine/acetylcholine bindingsplaats ( $\alpha$-BT) werden geïsoleerd uit beide muizenstammen. De relatieve frequenties van hybridomas kruisreactief met autologe muis AChR of gericht tegen de MIR of de $\alpha$-BT bindingsplaats waren hoger in gevoelige $\mathrm{C} 57 \mathrm{bl} / 6$ dan in minder gevoelige Balb/C muizen. Dit suggereert een mogelijk verschil in het beschikbare antilichaam repertoire. Het geobserveerde verschil in anti-AChR antilichaam repertoire werd eveneens nagegaan in de polyclonale anti-AChR response die ontstaat na immunisatie met AChR. De gemiddelde titer van antilichamen gericht tegen muis AChR was vergelijkbaar in beide muizenstammen. Daarbij was de concentratie van antilichamen gericht tegen de MIR en de $\alpha$-BT bindingsplaats in sera van beide muizenstammen vergelijkbaar na de tweede immunisatie met AChR. Bovendien waren de concentraties van anti-MIR en anti- $\alpha$-BT bindingsplaats antilichamen bij C57bl/6 muizen, met en zonder klinische verschijnselen vergelijkbaar. Deze resultaten laten zien dat stam afhankelijke verschillen in gevoeligheid voor de ziekte in het muize EAMG model, niet gerelateerd zijn aan verschillen in de totale concentratie van antilichamen tegen de MIR en $\alpha$-BT bindingsplaats. De fijne specificiteit, affiniteit en het effect van antilichamen met verschillende specificiteit die gezamenlijk binden aan de AChR, bepalen het netto effect op de AChR functie en de AChR afbraaksnelheid. Mogelijkerwijs verklaart dit het feit dat de totale anti-AChR antilichaam titer nauwelijks correleert met de mate van klinische verschijnselen; pathogene antilichamen omvatten waarschijnlijk een variabel gedeelte van de totale anti-AChR antilichaampopulatie. Bovendien zijn er verschillende fysiologische factoren zoals de AChR reserve en het aantal acetylcholine moleculen per quantum, welke samen de 'veiligheids marge' van de neuromusculaire signaaloverdracht bepalen. Deze factoren hebben eveneens invloed op het ontstaan van de ziekte.

In hoofdstuk 5 werd de genetische diversiteit bepaald van genen, die coderen voor het variabele gedeelte van de zware keten van anti-AChR mAbs. Om de diversiteit aan $V_{H}$ genen te inventariseren werd het $V_{H}$ gen familie gebruik van 65 anti-AChR en 20 anti-KLH mAbs, geïsoleerd uit EAMG gevoelige C57bl/6 en EAMG ongevoelige Balb/c muizen, bepaald d.m.v. RNA slot-blot analyse, waarbij gebruik werd gemaakt van probes specifiek voor negen $V_{H}$ gen families. Anti-AChR mAbs werden gecodeerd door $V_{H}$ genen, afkomstig van minstens 6 verschillende families. Het $V_{H}$ gen familie gebruik benaderde een stochastische verdeling over de verschillende $V_{H}$ gen families, waarbij de frequentie van gebruik van $V_{H}$ genen afkomstig uit een bepaalde familie proportioneel is met de grootte van die familie. Significante afwijkingen van deze verdeling werden gevonden voor de J606 en Vgam3.8 families. $V_{H}$ genen afkomstig uit de $\mathrm{J} 606$ familie werden in geen van de geteste anti-AChR mAbs aangetroffen, terwijl de Vgam3.8 familie duidelijk was oververtegenwoordigd in mAbs gericht tegen de $\alpha$-BT bindingsplaats. In tegenstelling tot 
deze bevinding werd geen bepaalde $V_{H}$ gen familie preferentieel gebruikt om mAbs gericht tegen de MIR te coderen. Anti-AChR mAbs specifiek voor enkel Torpedo AChR en mAbs die zowel Torpedo als muis AChR herkennen, vertoonden geen significant verschil in $V_{H}$ gen familie gebruik. Bovendien was er geen significant verschil in $V_{H}$ gen familie gebruik aantoonbaar tussen anti-AChR mAbs afkomstig van muizen met hoge of lage gevoeligheid voor EAMG. Verschillen in gevoeligheid voor de ziekte zijn daarom niet toe te wijzen aan een afwijking in het $V_{H}$ gen familie gebruik.

Anti-AChR mAbs die een kruisreactief idiotype delen, werden gecodeerd door $\mathrm{VH}_{\mathrm{H}}$ genen afkomstig uit minstens 6 verschillende families, wat suggereert dat er geen directe relatie bestaat tussen de expressie van dit kruisreactief idiotype en het gebruik van een beperkt aantal verschillende $V_{H}$ genen. Samenvattend laten deze gegevens zien, dat anti-AChR antilichamen worden gecodeerd door meerdere verschillende $V_{H}$ genen en dat geen verschuiving in het $V_{H}$ gen familie gebruik kan worden geobserveerd, zoals dat werd beschreven voor andere auto-antilichamen.

Naast de bepaling van het $V_{H}$ gen familie gebruik van muizen anti-AChR $m A$ bs werd eveneens het $V_{H}$ gen familie gebruik bepaald van een panel van rat anti-AChR mAbs, waarvan de fijne specificiteit en pathogeniciteit in detail zijn gedefinieerd.

In hoofdstuk 6 werd het $V_{H}$ gen familie gebruik van rat anti-AChR mAbs onderzocht met behulp van probes voor bekende muizen $V_{H}$ gen families. Slot-blot analyse van 21 rat anti-AChR mAbs liet zien, dat deze mAbs werden gecodeerd door $V_{H}$ genen afkomstig uit minstens 8 verschillende families. Er werd nagegaan of $V_{H}$ gen families analoog aan de muize $V_{H}$ gen families bestaan in de rat. Southern blot hybridisatie van DNA afkomstig van verschillende rattenstammen met probes voor 11 muize $V_{H}$ gen families, bevestigde het bestaan van analoge $V_{H}$ gen families in de rat. De complexiteit van deze rat $V_{H}$ gen families was verschillend van die van analoge families in de muis; de $J 558$ familie was kleiner terwijl de PC7183, X24, Q52, VH10 en $V_{H} 11$ families groter waren dan bij de muis.

De $V_{H}$ genen die coderen voor rat anti-AChR mAbs, volgden niet een stochastische verdeling over de verschillende $V_{H}$ gen families, als gevolg van oververtegenwoordiging van leden van S107 familie en ondervertegenwoordiging van de X24 familie. Het panel van rat anti-AChR mAbs bestond uit anti-MIR mAbs en mAbs gericht tegen overlappende epitopen gelegen op het intracellulaire oppervlak van de AChR. Een gedeeltelijke correlatie van het $V_{H}$ gen familie gebruik met de fijne specificiteit van sommige mAbs werd gevonden. MAbs gericht tegen de MIR met pathogeen potentieel in vivo of in vitro, werden frequent gecodeerd door $V_{H}$ genen van de Q52 familie, terwijl niet pathogene mAbs gericht tegen intracellulair gelegen epitopen frequent werden gecodeerd door $V_{H}$ genen van de PC7183 familie. Het frequente gebruik van $V_{H}$ genen uit een bepaalde $V_{H}$ gen familie suggereert het gebruik van verwante $V_{H}$ gen sequenties voor het coderen van antilichamen met overeenkomstige fijne specificiteit.

Rat anti-AChR mAbs brengen een kruisreactief idiotype tot expressie, dat bestaat uit kruisreactieve idiotopen, geassocieerd met de basisstructuur (framework) van de variabele regio, welke voorkomen op alle geteste anti-AChR mAbs en kruisreactieve idiotopen, geassocieerd met de antigeen bindingsplaats (paratoop), die enkel voorkomen op anti-MIR mAbs. Anti-AChR mAbs die zowel framework geassocieer- 
de als paratope geassocieerde kruisreactieve idiotopen tot expressie brengen, werden gecodeerd door $V_{H}$ genen afkomstig van verschillende $V_{H}$ gen families. Samenvattend laat het $V_{H}$ gen familie gebruik van rat anti-AChR mAbs zien, dat waarschijnlijk vele verschillende $\mathrm{V}_{\mathrm{H}}$ genen gebruikt kunnen worden voor het coderen van anti-AChR antilichamen. Dit is een onverwachte bevinding in het licht van het feit, dat een groot gedeelte van de anti-AChR antilichamen gericht zijn tegen de MIR welke uit een kleine groep van epitopen bestaat. Bovendien brengen anti-AChR mAbs een kruisreactief idiotype tot expressie, dat een of andere vorm van structurele overeenkomst tussen deze antilichamen suggereert. De expressie van een kruisreactief idiotype door anti-AChR mAbs zou gerelateerd kunnen zijn aan de $V_{L}$ keten; sequentie analyse van $V_{L}$ ketens van 4 rat anti-MIR mAbs liet een onderlinge aminozuur homologie zien van meer dan $90 \%$ (Dr S.J. Tzartos, persoonlijke mededeling). Anti-AChR mAbs zouden eveneens kunnen worden gecodeerd door 'diversity' en/of 'joining' gen segmenten met grote overeenkomst. In toekomstige studies zal de aminozuur sequentie van anti-AChR mAbs bepaald worden om eventuele structurele overeenkomsten tussen anti-AChR antilichamen aan te tonen. Structurele overeenkomsten tussen immuunreceptoren zoals antilichaam en de $T$ cell receptor, welke specifiek zijn voor AChR reactieve B en T lymfocyten, kunnen wellicht een aangrijpingspunt zijn voor specifieke manipulatie van de auto-immuun respons tegen de $\operatorname{AChR}(7,8)$.

Sequentie analyse zou bovendien informatie kunnen geven over de oorsprong van deze auto-antilichamen; maken deze auto-antilichaam sequenties deel uit van het repertoire zoals dat in de 'germline' genen wordt gecodeerd? $(9,10)$. Verder zou het vergelijken van anti-AChR antilichaam sequenties met reeds bekende sequenties van antilichamen gericht tegen exogene antigenen, informatie kunnen geven over het ontstaan van anti-AChR antilichamen uit niet-pathogene antilichamen d.m.v. beperkte somatische mutaties (10). 


\section{References / Referenties}

1 Courtney J, Steinbach JH. (1981). Age changes in neuromuscular junction morphology and acetylcholine distribution on rat skeletal muscle fibres. J. Physiol. 320:435-447

2 Lindstrom JM, Einarson BL, Lennon VA, Seybold ME. (1976). Pathological mechanisms in experimental autoimmune myasthenia gravis. I. Immunogenicity of syngeneic muscle acetylcholine receptor and quantative extraction of receptor and antibody-receptor complexes from muscles of rats with experimental autoimmune myasthenia gravis. $\mathrm{J}$. Exp. Med. 144:726-738

3 Lindstrom J, Einarson B. (1979). Antigenic modulation and receptor loss in experimental autoimmune myasthenia gravis. Muscle and Nerve. 2:173-179

4 Corey AL, Richman DP, Agius MA, Wollmann RL. (1987). Refractoriness to a second episode of experimental myasthenia gravis. Correlation with AChR concentration and morphological appearance of the postsynaptic membrane. J. Immunol. 138:3269-3275

5 Yechiel E, Barenholz Y. (1985). Relationships between membrane lipid composition and biological properties of rat myocytes. J. Biol. Chem. 260:9123-9131

6 De La Fuente M. (1985). Changes in the macrophage function with aging. Comp. Biochem. Physiol. 81A:935-938

7 Verschuuren GM, Graus YMF, van Breda Vriesman PJC, Tzartos SJ, De Beats MH. (1991). In vivo effects of neonatal administration of anti-idiotype antibodies on experimental autoimmune myasthenia gravis. Autoimmunity 10:173-179

8 Infante AJ, Levcovitz H, Gordon V, Wall KA, Thompson PA, Krolick KA. (1992). Preferential use of a $T$ cell receptor $V_{\beta}$ gene by acetylcholine receptor reactive $T$ cells from myasthenia gravis-susceptible mice. J. Immunol. 148:3385-3390

9 Brigido MM, Stollar BD. (1991). Two induced anti-Z-DNA monoclonal antibodies use $V_{H}$ gene segments related to those of anti-DNA autoantibodies. J. Immunol. 146:2005-2009

10 Chao M, Voss EW. (1992). Autoimmune $V_{H}$ gene family: PCR-generated murine germline $V_{H} 10$ genes. Molecular Immunol. 29:439-442

11 Behar SM, Lustgarten DL, Corbet S, Scharff MD. (1991). Characterization of somatically mutated $\mathrm{S} 107 \mathrm{~V}_{\mathrm{H}} 11$ encoded anti-DNA autoantibodies derived from autoimmune (NZB $x$ NZW) Fy mice. J. Exp. Med. 173:731-741 


\section{Publications}

De Baets MH, Verschuuren JJGM, Graus YMF, van Breda Vriesman PJC. (1990). Idiotype network in experimental autoimmune myasthenia gravis. In: Idiotype networks in biology and medicine. Oosterhaus A, Uytdehaag F. Eds. Excerpta Medica Elsevier, Amsterdam.

Verschuuren JJGM, Graus YMF, Tzartos SJ, van Breda Vriesman PJC, De Baets $\mathrm{MH}$. (1991). Paratope- and framework- related cross-reactive idiotopes on antiacetylcholine receptor antibodies. J. Immunol. 146:941-948

Verschuuren JJGM, Graus YMF, van Breda Vriesman PJC, De Baets MH. (1991). In vivo effects of neonatal administration of anti-idiotype antibodies on experimental autoimmune myasthenia gravis. Autoimmunity 10:173-179

Verschuuren JJGM, Graus YMF, Theunissen ROM, Yamamoto T, Vincent A, van Breda Vriesman PJC, De Beats MH. (1992). Role of acetylcholine receptor antibody complexes in muscle in experimental autoimmune myasthenia gravis. J. Neuroimmunol. 36:117-125

Graus YMF, De Baets MH. Myasthenia gravis: an autoimmune response against the acetylcholine receptor. Immunological Res. in press

Graus YMF, Verschuuren JJGM, Bos NA, van Breda Vriesman PJC, De Baets MH. $V_{H}$ gene family utilization of anti-AChR monoclonal antibodies in experimental autoimmune myasthenia gravis. Ann. N. Y. Acad. Sci. in press.

Graus YMF, Verschuuren JJGM, Bos NA, van Breda Vriesman PJC, De Baets MH. $V_{H}$ gene family utilization of anti-AChR antibodies in experimental autoimmune myasthenia gravis. J. Neuroimmunol. in press

Graus YMF, Verschuuren JJGM, Spaans F, Jennekens F, van Breda Vriesman PJC, De Baets $\mathrm{MH}$. Age related resistance to experimental autoimmune myasthenia gravis in rats. Submitted for publication. 
Graus YMF, van Breda Vriesman PJC, De Baets MH. Characterization of anti-acetylcholine receptor antibodies from mice differing in susceptibility for experimental autoimmune myasthenia gravis. Submitted for publication.

Graus YMF, Bos NA, Tzartos SJ, van Breda Vriesman PJC, De Baets MH. $V_{H}$ gene family utilization of rat anti-acetylcholine receptor monoclonal antibodies. Submitted for publication. 


\section{Dankwoord}

\section{"A thousand miles journey begins with a single step"}

Het uitvoeren van een promotie onderzoek was voor mij een avontuurlijke reis waarop ik kennis heb gemaakt met wetenschappelijk onderzoek. In een onderzoek worden vragen beantwoord en nieuwe vragen gesteld waardoor deze reis nog lang niet is beëindigd. Toch wil ik op deze plaats iedereen bedanken die gedurende de afgelopen 3 jaar een 'eind met mij is meegelopen' op weg naar dit eindresultaat en een onmisbare bijdrage heeft geleverd aan het tot stand komen van dit proefschrift.

Allereerst wil ik een aantal mensen bedanken voor hun bijdrage aan de in dit proefschrift gepresenteerde resultaten. Prof. Dr. F. Jennekens en Henk Veldman wil ik graag bedanken voor hun kennis en vaardigheid op het gebied van de electronenmicroscopie. Mijn dank gaat eveneens uit naar Prof. Dr. Spaans voor de nauwgezette begeleiding van het electromyografisch onderzoek. Dr. N.A. Bos, beste Nico, jij maakte mij wegwijs op het gebied van de $V_{H}$ gene analyse en hebt mij tijdens dit onderzoek steeds geholpen met goede tips en waardevolle discussies over de resultaten; bedankt voor de prettige samenwerking!

Dit proefschrift zou echter niet tot stand zijn gekomen zonder de hulp van de groep immunologie waarbinnen ieder een persoonlijke inbreng in dit proefschrift heeft gehad. Dr. J. Verschuuren, beste Jan, jij hebt mij in het begin wegwijs gemaakt in het myasthenia gravis onderzoek; jouw enthousiaste en nauwgezette manier van onderzoek doen, is nog steeds inspirerend. Ik kijk met veel plezier terug naar de periode waarin we samen aan het myasthenie onderzoek hebben gewerkt en ook toen jij in opleiding ging bleef je mijn onderzoek met interesse volgen, wat ik zeer op prijs heb gesteld. Mieke Henfling, lieve Mieke, het was een groot genoegen om gedurende twee jaar samen met jou aan dit onderzoek te werken; jouw grote technische vaardigheid en "liefde voor de cellen" zijn onmisbaar geweest voor het tot stand komen van dit proefschrift. Ik wil je daarom in het bijzonder bedanken voor de bergen werk die jij verzette en bovenal voor het fijne gezelschap dat je was en nog steeds bent, nu we "buren" zijn. Ruud Aarts, beste Ruud jou bedank ik voor het accuraat uitvoeren van de resterende experimenten die nodig waren voor het afronden van dit proefschrift. Ik hoop dat we als team in de toekomst net zo prettig kunnen samenwerken, met vooral veel muziek! Verder dank ik José van de Gaar, Ruud Theunissen, Wien Vlek en Henk van Rie die in het lab altijd klaar stonden met raad en daad en een gezellige babbel. Francien Teng dank ik voor de hulp bij het maken van de tabellen.

En natuurlijk niet te vergeten Gerard Majoor, Adriaan Duivenstein, Jan Damoiseaux en de medepromovendi Wiel Wodzig. Chris Nieuwenhof, Petra Koornstra en Leo 
Beijleveld die tijdens de vele werkbesprekingen waardevolle discussies voerden over mijn resultaten.

Een bijzonder woord van dank gaat uit naar Prof. Dr. P. van Breda Vriesman en Dr M.H. De Baets die samen hebben gezorgd voor de uitstekende begeleiding van het onderzoek. Beste Peter, ik dank je vooral voor de betrokkenheid bij dit onderzoek waarvan je steeds de grote lijnen bewaakte. Jouw brede inzicht en creatieve kijk op het verrichten van immunologisch onderzoek leidde vaak tot vernieuwende inzichten en heeft mijn "onderzoeks blik" beslist verruimd. Beste Marc, allereerst waardeer ik zeer de mogelijkheid die jij mij hebt geboden om, onder jouw leiding, dit onderzoek uit te voeren. Met jouw grote inzicht en ervaring op het gebied van het myasthenie onderzoek heb je alles steeds in goede banen geleid, wat essentieel was voor het welslagen van dit onderzoek. Een uitgebreide kennis van de literatuur en goede ideeën gaven het onderzoek telkens de juiste impulsen, waarbij je altijd ruimte liet voor mijn eigen ideeën. Ik hoop dan ook dat wij onze prettige samenwerking in de toekomst kunnen voortzetten.

Tot slot wil ik alle familie en vrienden bedanken die gedurende de afgelopen jaren met mij hebben meegeleefd, maar bovenal dank ik mijn vader en moeder voor de mogelijkheden die zij mij hebben geboden om te bereiken wat ik wilde. Lieve Mia en Ger, jullie hebben steeds met veel interesse meegeleefd met het onderzoek en zijn daarbij een niet aflatende stimulans voor mij geweest.

Lieve Lucie, jou wil ik speciaal bedanken voor alle "steuntjes in de rug" die mij weer op weg hielpen als het tegenzat en voor de ruimte en zorg die jij mij gaf, zodat ik steeds ongestoord aan mijn proefschrift kon werken.

Allemaal bedankt ! 


\section{Curriculum vitae}

Yvo Graus werd geboren op 1 maart 1963 in Heerlen. Hij behaalde in 1981 en 1983 respectievelijk het diploma HAVO en Atheneum $\beta$ aan het Sintermeerten college te Heerlen. Vervolgens studeerde hij medische biologie aan de Universiteit van Amsterdam. In 1988 behaalde hij het doctoraal examen met als afstudeer opdrachten moleculaire biologie bij het Nederlands kanker instituut in Amsterdam, onder leiding van Dr. R. Nusse en immunologie bij de vakgroep immunologie van de rijksuniversiteit Limburg in Maastricht, onder leiding van Dr. M.H De Baets. Van maart 1988 tot maart 1992 was hij werkzaam bij de vakgroep immunologie van de Rijksuniversiteit Limburg. Onder leiding van Dr. M.H. De Baets en Prof. Dr. P.J.C. van Breda Vriesman werd gedurende deze periode het onderzoek verricht beschreven in dit proefschrift. Vanaf maart 1992 is hij als post-doctoraal onderzoeker werkzaam bij de vakgroep immunologie van de Rijksuniversiteit Limburg. 

